UNIVERSIDADE DE SÃO PAULO

INSTITUTO DE GEOCIÊNCIAS

\title{
ESTABILIDADE DE ENCOSTAS E CONDICIONANTES GEOLÓGICOS, GEOMORFOLÓGICOS E ESTRUTURAIS, NUM TRECHO DA SERRA DE CUBATÃO
}

JOSÉ GONÇALVES MACHADO FILHO

Orientador: Prof. Dr. Georg Robert Sadowski

DISSERTAÇÃO DE MESTRADO

COMISSÃO JULGADORA

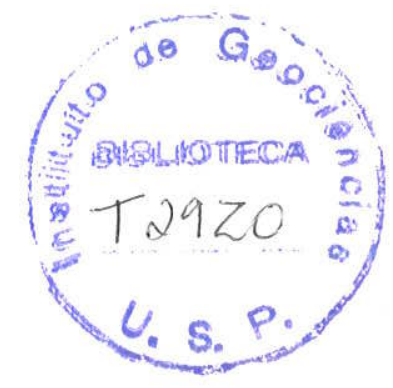

Nome

Assinatura

Presidente: Prof. Dr. Georg Robert Sadowski

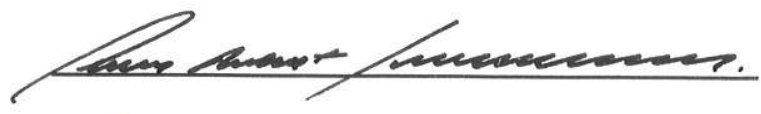

Examinadores: Prof. Dr. Ginaldo Ademar da Cruz Campanha

Prof. Dr. Jayme de Oliveira Campos

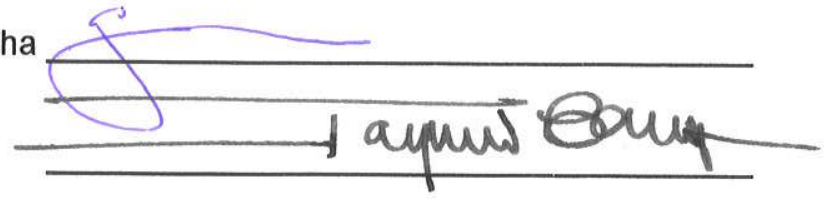

SÃO PAULO

2000 


\title{
UNIVERSIDADE DE SÃO PAULO \\ INSTITUTO DE GEOCIÊNCIAS
}

\section{ESTABILIDADE DE ENCOSTAS E CONDICIONANTES GEOLÓGICOS, GEOMORFOLÓGICOS E ESTRUTURAIS, NUM TRECHO DA SERRA DE CUBATÃO}

\author{
José Gonçalves Machado Filho
}

Orientador: Prof. Dr. Georg Robert Sadowski
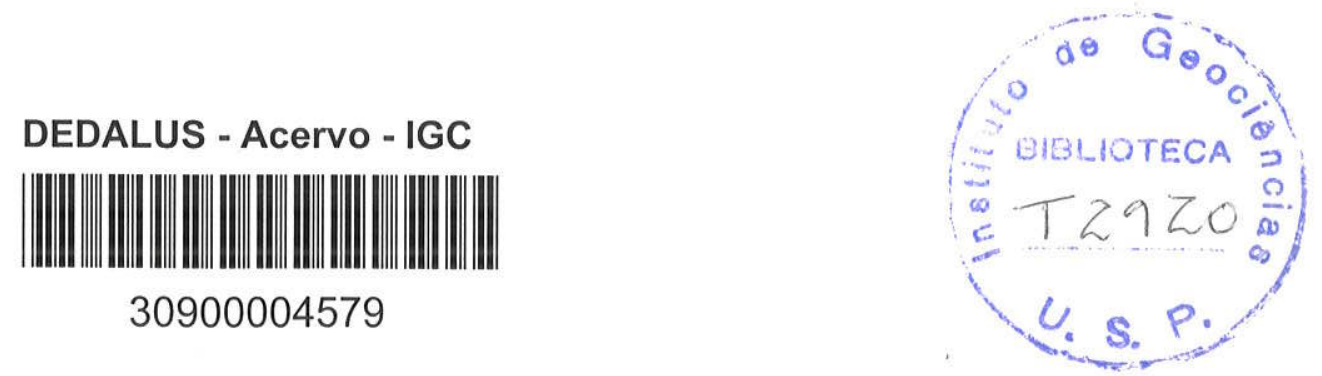

DISSERTAÇÃO DE MESTRADO

Programa de Pós-Graduação em Geoquímica e Geotectônica

SÃO PAULO

2000 


\section{DEDICATÓRIA}

À minha esposa

$e$ aos meus filhos 


\section{AGRADECIMENTOS}

Deveria agradecer a muitas pessoas que me ajudaram de alguma forma a concretizar este trabalho, tornando realidade um antigo anseio, que não se mostrou superado.

São pessoas que encontrei ao longo da vida, que me mostraram o lado bom das coisas, que a vida vale a pena e que devemos lutar por nosso objetivo de desenvolvimento pessoal qualquer que seja o momento.

Objetivamente, sou muito grato ao amigo e professor Dr. Georg Robert Sadowski que orientou-me neste trabalho, abrindo-me as portas para uma nova etapa de estudos.

Agradeço aos diversos professores do Instituto de Geociências que ministraram as disciplinas que frequentei durante o curso, bem como àqueles com quem tive 0 privilégio de conversar e apreender conhecimentos.

Quero fazer referência à gentileza no tratamento recebido das secretárias do Departamento de Pós-graduação e à eficiência da Biblioteca do Instituto.

Meu agradecimento à CAPES pela bolsa recebida durante o primeiro ano do curso.

Devo lembrar a permissão concedida pela DERSA para consulta em seu arquivo técnico e biblioteca e tambem a autorização inicial para circulação nas estradas de serviço do sistema Anchieta-Imigrantes, posteriormente referendada pela ECOVIAS.

Meu agradecimento especial à minha esposa $e$ às minhas filhas que permanentemente me incentivam.

Meu agradecimento a Deus que está sempre comigo. 


\section{ÍNDICE}

RESUMO

$\mathrm{XV}$

ABSTRACT

xvi

\section{CAPÍTULO I}

\section{INTRODUÇÃO}

I.1. HISTÓRICO - OBJETIVOS …............................................................. 1

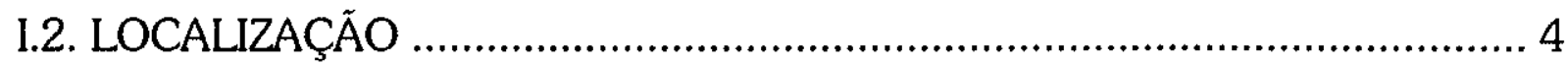

I.3. VISÃO GERAL DA ÁREA ….......................................................... 7

I.4. METODOLOGIA - FONTES DE INFORMAÇÃO ................................... 9

I.5. ESTUDOS GEOLÓGICOS ANTERIORES …..................................... 10

\section{CAPÍTULO II}

ARCABOUÇO GEOLÓGICO-TECTÔNICO REGIONAL

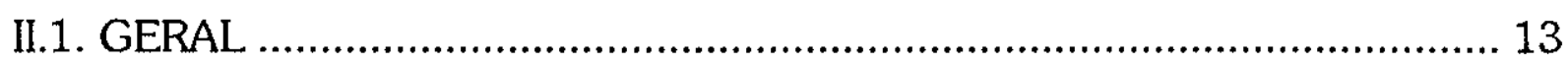

II.2. ZONA DO FALHAMENTO DE CUBATÃO …................................... 17

\section{CAPÍTULO III}

\section{GEOLOGIA DA ÁREA}

III.1. ESTRATIGRAFIA

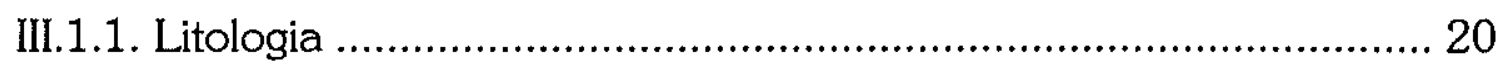

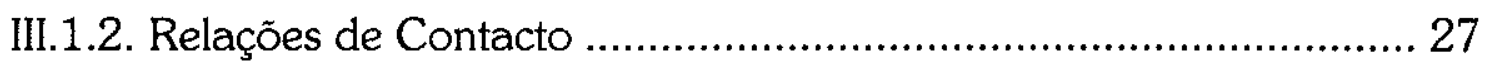




\section{III.2. ESTRUTURAS}

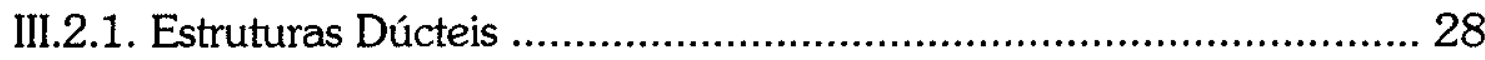

III.2.2. Estruturas Rúpteis - Fotolineamentos ...................................... 30

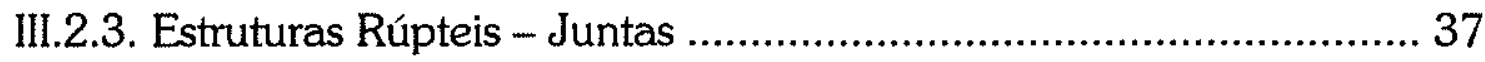

III.2.4. Análise Comparativa das Estruturas Rúpteis .............................. 46

\section{CAPÍtULLO IV}

\section{GEOMORFOLOGIA DA ÁREA}

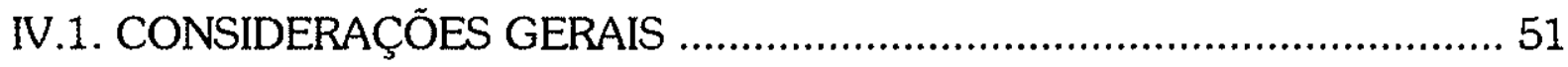

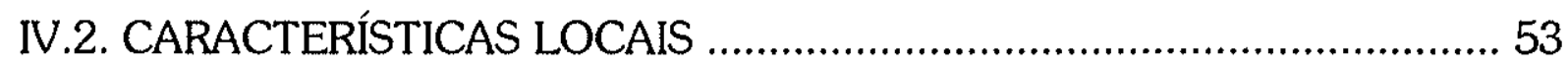

IV.3. VISÃO LOCAL E DAS ÁREAS CIRCUNDANTES .............................. 58

\section{CAPÍTULO $\mathrm{V}$}

\section{CLIMA, PLUVIOMETRIA E VEGETAÇÃo}

V.1. CONSIDERAÇÕES SOBRE O CLIMA E INFLUÊNCIA

DA PLUVIOMETRIA

V.2. CONSIDERAÇÕES SOBRE O TIPO E INFLUÊNCIA

DA VEGETAÇÃO 68

\section{CAPÍTULO VI}

\section{ASPECTOS CONCEITUAIS DA ESTABILIDADE DE ENCOSTAS}

VI.1. MOVIMENTOS DE ENCOSTAS - CLASSIFICAÇÃO E FATORES INTERVENIENTES

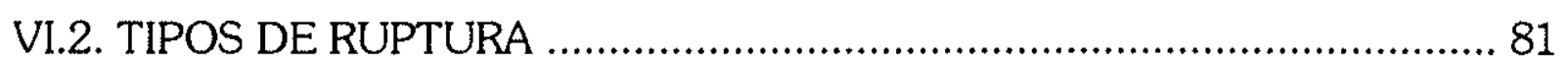

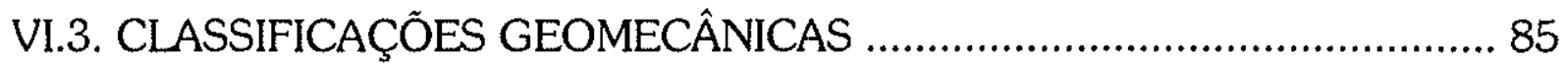




\section{VI.4. ANÁLISE DE ESTABILIDADE DE TALUDES}

VI.4.1. Parâmetros de Estabilidade ........................................................ 94

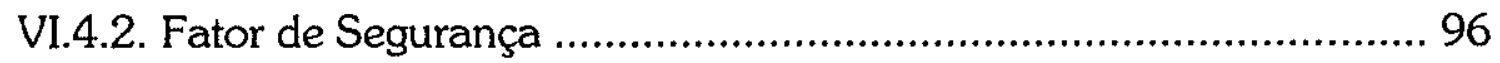

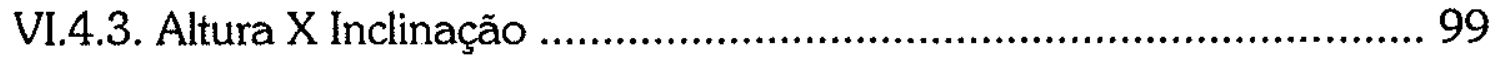

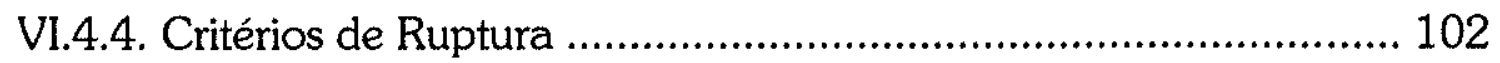

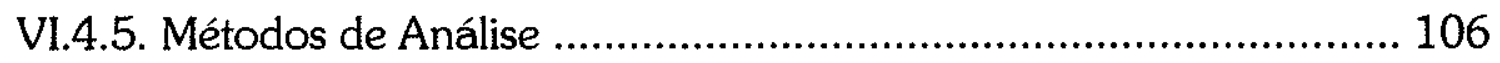

\section{CAPÍTULO VII}

\section{CONDICIONANTES LOCAIS DE ESTABILIDADE}

VII.1. PERFIL DE ALTERAÇÃO E PARÂMETROS DE ESTABILIDADE ....... 111

VII.2. COMPARTIMENTAÇÃO DA ÁREA ….............................................. 115

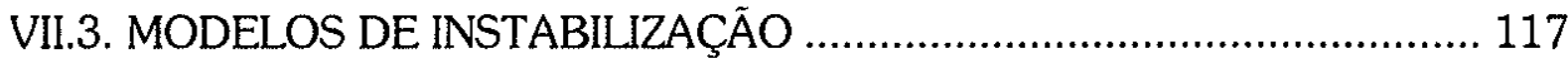

VII.4. TIPOS DE TRATAMENTOS E CONTENÇÕES UTILIZADOS

VII.4.1. Considerações Gerais e Principais Tipos ................................ 121

VII.4.2. Muros Atirantados ................................................................ 129

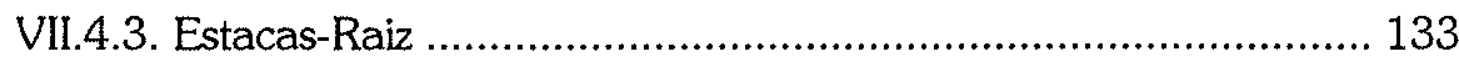

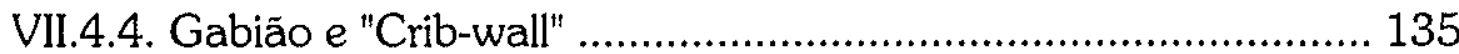

VII.4.5. Anéis de Proteção em Viadutos ............................................. 137

\section{CAPÍtULO VIII}

\section{EXEMPLOS HISTÓRICOS DE INSTABILIZAÇÕES NA ÁREA}

VIII.1. OS BAIRROS-COTA DA VIA ANCHIETA 139 
VIII.2. ESCORREGAMENTOS NA RODOVIA DOS IMIGRANTES -

VIII.3. ESCORREGAMENTOS NO CAMINHO DO MAR -

- FEVEREIRO/1994

VIII.4. RUPTURA NA VIA ANCHIETA - DEZEMBRO/1999

155

CAPÍTULO IX

CONCLUSÕES 


\section{ÍNDICE DE FIGURAS}

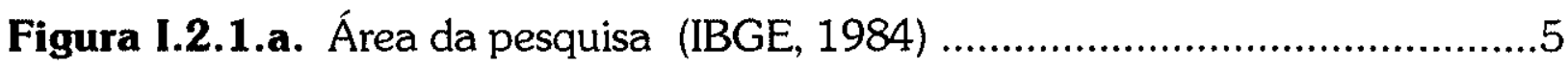

Figura I.2.1.b. Localização da área e base topográfica ...................................6

Figura II.1.1. Lineamento ao longo da margem este brasileira

(Chang et al,1992) 15

Figura II.1.2. Províncias do embasamento do escudo precambriano

brasileiro (Cordani et al, 1984) 16

Figura II.2.1. Sistema de megafalhas Cubatão (Sadowski, 1991) ................. 18

Figura II.2.2. Sistema de juntas associadas às grandes transcorrências

(Egydio da Silva et al, 1982) 19

Figura III.1.1.1. Mapa Geológico (baseado em Sadowski, 1974, 1993) ......... 22

Figura III.1.1.2.a. Situação da área e articulação das folhas IBGE ................. 23

Figura III.1.1.2.b. Seção geológica A-A' ................................................... 23

Figura III.1.1.3. Seção B-B': relações espaciais da faixa de metassedimentos do vale do Cubatão, com as rochas do Bloco Juquitiba (Sadowski, 1991) ................... 26

Figura III.2.2.1. Mapa esquemático da área com fotolineamentos ................. 31

Figura III.2.2.2. Diagrama de frequências em rosácea. Área do Planalto ....... 32

Figura III.2.2.3. Diagrama de frequências em rosácea. Área da Serra e Vale do Cubatão ...................................... 33

Figura III.2.2.4. Diagrama de frequências em rosácea. Área A ...................... 34

Figura III.2.2.5. Diagrama de frequências em rosácea. Área B ..................... 35

Figura III.2.3.1. Ponto A1. Estereograma de 92 polos de juntas ................... 41

Figura III.2.3.2. Ponto A2. Estereograma de 66 polos de juntas ................... 42

Figura III.2.3.3. Ponto B1. Estereograma de 81 polos de juntas ................... 43 
Figura III.2.3.4. Ponto B2. Estereograma de 154 polos de juntas

Figura III.2.3.5. Ponto B3. Estereograma de 94 polos de juntas 45

Figura III.2.4.1. Ponto A1. Estereograma das estruturas rúpteis predominantes

Figura III.2.4.2. Ponto A2. Estereograma das estruturas rúpteis predominantes 48

Figura III.2.4.3. Ponto B1. Estereograma das estruturas rúpteis predominantes 48

Figura III.2.4.4. Ponto B2. Estereograma das estruturas rúpteis predominantes

Figura III.2.4.5. Ponto B3. Estereograma das estruturas rúpteis predominantes 49

Figura IV.2.1. Mapa Geomorfológico 55

Figura IV.3.1. Identificação de elementos da imagem Landsat 60

Figura V.1.1. Localização das estações pluviométricas 64

Figura V.1.2. Correlação entre chuvas e escorregamentos na Serra do Mar, município de Cubatão (Tatizana et al, 1987)

Figura V.2.1. Desmatamento e variação esquemática da estabilidade das encostas (Wolle, 1987)

Figura VI.1.1. Variação da coesão aparente do solo coluvionar da Serra do Mar em função do grau de saturação(Carvalho, 1991) 78

Figura VI.2.1. Ruptura em solo coesivo (Cernica, 1994) 82

Figura VI.2.2. Tipos de ruptura plana (Piteau e Martin, 1981) 82

Figura VI.2.3. Principais tipos de rupturas em taludes rochosos e suas condições estruturais representadas em estereogramas (Hoek \& Bray, 1997) 83 
Figura VI.4.1.1. Tensões normal e cisalhante num bloco de solo ou rocha na condição limite de ruptura (Hoek \& Bray, 1997) 95

Figura VI.4.2.1. Forças atuantes num bloco em equlíbrio (Hoek \& Bray, 1997) 97

Figura VI.4.2.2. Equilibrio de forças num bloco atirantado (Hoek \& Bray, 1997) 97

Figura VI.4.3.1. Relação altura X inclinação de taludes para diferentes materiais (Hoek \& Bray, 1997) 100

Figura VI.4.3.2. Altura X inclinação de taludes em rochas duras (Hoek, 1995) 101

Figura VI.4.4.1. Curva tensão X deformação de material elasto-plástico

(Hatcher Junior, 1995) 103

Figura VI.4.4.2. Curva tensão X deformação de material elástico (Hatcher Junior, 1995) 103

Figura VI.4.4.3. Critério de ruptura de Mohr-Coulomb 105

Figura VI.4.4.4. Envoltória de Mohr 105

Figura VI.4.5.1. Grau de segurança de um talude em termos probabilísticos (Gama,1997) 107

Figura VI.4.5.2. Análise de rupturas planas em projeção estereográfica (Hoek e Bray, 1997) 109

Figura VII.1.1. Perfil de alteração típico de rochas metamórficas em região de serra (Pastore, 1995)

Figura VII.1.2. Perfil de alteração na região do viaduto VA-16 da Rodovia dos Imigrantes (Machado Filho, 1974) 112

Figura VII.3.1. Instabilização em solo coluvionar (Wolle, 1988) 119 
Figura VII.4.2.1. Tipos de muros atirantados na Rodovia dos Imigrantes

Figura VII.4.3.1. Contenção de encosta com estacas-raiz

Figura VII.4.4.1. Gabião tipo caixa ou gaiola. (Maccaferri, 1979) 135

Figura VII.4.5.1. Seção geológica esquemática em região de tálus, com anéis de proteção .(Machado Filho, 1974) 138

Figura VIII.1.1. Localização dos Bairros-Cota .140 


\section{ÍNDICE DE FOTOGRAFIAS}

Fotografia III.2.1.1. Dobra em zona de cisalhamento dúctil .........................2 29

Fotografia III.2.1.2. Boudins em zona de cisalhamento dúctil-rúptil ...............29

Fotografia III.2.3.1. Ponto A1. Visão restrita do local ................................. 41

Fotografia III.2.3.2. Ponto A2. Vista do afloramento .................................... 42

Fotografia III.2.3.3. Ponto B1. Vista parcial do local ................................. 43

Fotografia III.2.3.4. Ponto B2. Vista do corte ............................................. 44

Fotografia III.2.3.5. Ponto B3. Vista parcial do afloramento .......................... 45

Fotografia IV.2.1. Planalto Paulistano. Vista parcial junto

à Represa do Rio das Pedras ................................... 56

Fotografia IV.2.2. Serra de Cubatão. Visão geral da vertente do Caminho do Mar 56

Fotografia IV.2.3. Serra de Cubatão. Vista da vertente direita do rio Cubatão, com Planície Costeira ao fundo

Fotografia IV.2.4. Planície Costeira. Vista parcial com a cidade de São Vicente ao fundo

Fotografia V.2.1. Aspecto geral da mata na Serra de Cubatão ........................ 70

Fotografia V.2.2. Área com indícios de degradação vegetal ........................... 70

Fotografia V.2.3. Vegetação destruida na encosta do viaduto VA-5 da Rodovia dos Imigrantes, Nov/1974 (Desenvolvimento Rodoviário SA) ........... 73

Fotografia V.2.4. Aspecto da vegetação no mesmo local em Out/1999 ........... 73

Fotografia VII.3.1. Escorregamentos translacionais na Serra de Cubatão ...... 119

Fotografia VII.3.2. Escorregamento de solo coluvial arrastando 
Fotografia VII.4.1.1. Muro de concreto em corte da estrada de serviço da Rodovia dos Imigrantes. A juzante, muro atirantado

Fotografia VII.4.1.2. Muros de pedra fazendo parte de galeria e escada hidráulica 124

Fotografia VII.4.1.3. Concreto projetado em zona de emboque de túnel. Janela de serviço do TA-9, Rodovia dos Imigrantes 125

Fotografia VII.4.1.4. Encosta protegida com chumbadores e tela metálica ... 125

Fotografia VII.4.1.5. Drenagem superficial - escada hidráulica .................. 127

Fotografia VII.4.1.6. Drenos tubulares profundos em região de tálus ........... 127

Fotografia VII.4.1.7. Cordóes vegetais em encosta sobre emboque de túnel

Fotografia VII.4.1.8. Cordões vegetais em encosta de estrada de serviço ..... 128

Fotografia VII.4.2.1. Muro atirantado de placas retangulares na Rodovia dos Imigrantes 130

Fotografia VII.4.2.2. Muro de sapatas atirantadas

Fotografia VII.4.2.3. Sapatas atirantadas reforçando zona de fundação de viaduto, na Rodovia dos Imigrantes

Fotografia VII.4.2.4. Tirante de 12 fios de aço, em fase de montagem 132

Fotografia VII.4.2.5. Sapata de concreto, com tirante posicionado 132

Fotografia VII.4.2.6. Tirante já protendido, com a cabeça de cravação 132

Fotografia VII.4.2.7. Sapata terminada, com a cabeça do tirante revestida .. 132

Fotografia VII.4.3.1. Estacas-raiz em encosta a montante de emboque de túnel, na Rodovia dos Imigrantes 134

Fotografia VII.4.3.2. Estacas-raiz reforçando encosta em zona de fundação de viaduto, na Rodovia dos Imigrantes 134

Fotografia VII.4.4.1. Canal de drenagem construido com muros e colchão de gabiões, na estrada de serviço 
Fotografia VII.4.4.2. Estrada de serviço no trecho da serra, construida sobre "crib-wall"

Fotografia VII.4.5.1. Anéis de proteção em viaduto da Rodovia dos Imigrantes 138

Fotografia VIII.1.1. Vista parcial do bairro na Cota 400 142

Fotografia VIII.1.2. Bairros-Cota nas encostas da Serra de Cubatão 142

Fotografia VIII.1.3.. Vista parcial do Morro Preto na Cota 95 (Machado Filho, 1994) 144

Fotografia VIII.1.4. Casa sobre berma de equilibrio no Morro Preto (Machado Filho, 1994) 144

Fotografia VIII.2.1. Vista da encosta do TA-6, emboque

S. Paulo (outubro/1975)

Fotografia VIII.2.2. Vista parcial à juzante do TA-6, emboque S. Paulo com tratamento vegetal (setembro/1976)

Fotografia VIII.2.3. Encosta do TA-9, emboque S. Paulo (DERSA, fevereiro/1976) . 148

Fotografia VIII.3.1. Foto aérea das encostas do Caminho do Mar.

Escala 1:25000 (BASE, março/1994) 150

Fotografia VIII.3.2. Ruptura afetando meia pista no Caminho do Mar, $\mathrm{km} \mathrm{47,6} \mathrm{(abril/1994)}$ 151

Fotografia VIII.3.3. Ruptura seccionando a pista no Caminho do Mar, $\mathrm{km} 47,9$ (abril/1994) 152

Fotografia VIII.3.4. Ruptura seccionando a pista no Caminho do Mar, $\mathrm{km} \mathrm{48,1} \mathrm{(abril/1994)}$ 153

Fotografia VIII.4.1. Escorregamento inicial na Via Anchieta em 13/12/1999 (http://ecovias.com.br) 156

Fotografia VIII.4.2. Evolução do escorregamento em direção à pista em 23/12/1999 (http://ecovias.com.br) 156 


\section{ÍNDICE DE IMAGENS}

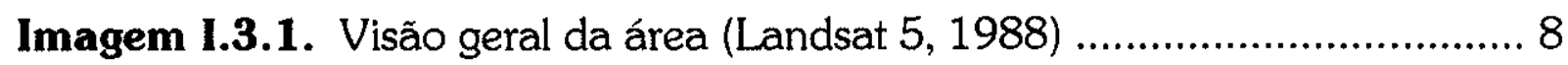

Imagem IV.3.1. Visão local e das áreas circundantes

(Landsat 5, 1995).

61 


\section{ÍNDICE DE TABELAS}

Tabela 1.1.1. Acidentes importantes causados por escorregamentos no Brasil (Augusto Filho, 1994)

Tabela III.2.4.1. Quadro comparativo das estruturas rúpteis preponderantes (direção/mergulho) 50

Tabela V.1.1. Alturas anuais de chuvas em mm. (DAEE/CTH, 1997) .............. 65

Tabela VI.1.1. Classificação dos movimentos de encostas (Varnes, 1978) ....... 76

Tabela VI.1.2. Fatores deflagradores dos movimentos de encostas

(Varnes, 1978) 76

Tabela VI.1.3. Resistência de solos com macroestruturas

(Sandroni, 1985) 78

Tabela VI.1.4. Valores de ângulo de atrito para rochas intactas, com juntas e com juntas cizalhadas (Hoek, 1972) 80

Tabela VI.3.1. Principais classificações geomecânicas (Beniawski, 1989) 86

Tabela VI.3.2. Índices característicos das principais clasificações geomecânicas (ABGE, 1998) 86

Tabela VI.3.3. Sistema RMR de classificação geomecânica

(Beniawski, 1979) 87

Tabela V1.3.4. Parâmetros rochoso utilizados na obtenção do índice $Q$ da classificação NGI (Barton et al, 1974) 89

Tabela VI.3.5. Valor de ajuste devido às juntas (Romana, 1985) 93

Tabela VI.3.6. Valor de ajuste devido ao método de escavação (Romana, 1985) 93

Tabela VI.3.7. Classificação SMR (Romana, 1985) 93

Tabela VI.4.1.1. Parâmetros típicos de solos e rochas (Hoek e Bray, 1997) ..... 95 
Tabela VI.4.5.1. Principais métodos analíticos de análise de estabilidade (IPT,1990)

Tabela VII.1.1. Resultados de ensaios de cisalhamento direto em amostras das encostas próximas aos túneis TA-6 e TA-7, da Rodovia dos Imigrantes (IPT, 1976, apud Wolle, 1988)

Tabela VII.1.2. Parâmetros médios de resistência ao cisalhamento dos solos (IPT, 1976, apud Wolle, 1988) 


\section{RESUMO}

A Serra de Cubatão, denominação local da Serra do Mar é constituida predominantemente por rochas metamórficas de alto e médio grau, dos Complexos Embu e Costeiro, do Proterozóico Superior, englobando especialmente gnaisses, granito-gnaisses, xistos, filitos, milonitos, quartzitos e calco-silicatadas.

Sua origem está intimamente ligada à origem e desenvolvimento da costa sudeste brasileira, a qual se iniciou no período Jurássico/Início do Cretáceo, quando houve a separação dos blocos da América do Sul e África, originalmente constituintes do supercontinente do Gondwana.

Os contactos litológicos na área são bastante lineares e sub-paralelos,

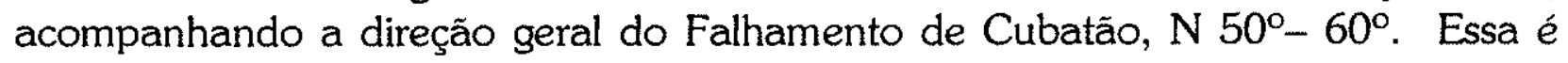
tambem a direção geral das principais estruturas regionais e locais, como dobramentos, falhamentos, foliações, intrusões graníticas, etc.

$\mathrm{O}$ perfil de alteração no trecho escarpado é basicamente representado pela sequência solo coluvial/solo saprolítico/saprolito/rocha sã, havendo localmente diversas ocorrências de tálus. As espessuras de alteração atingem dezenas de metros nas cotas superiores junto à borda do Planalto Paulistano (cerca de $750 \mathrm{~m}$ de altitude), diminuindo gradativamente à medida que se desce a escarpa. Abaixo da cota $300 \mathrm{~m}$, sua espessura se reduz a poucos metros, sendo comum o afloramento de rocha sã nos talvegues e à meia encosta.

A área tem sido palco ao longo dos anos, de movimentos de massas que atuam como agentes naturais modeladores das encostas, manifestando-se tanto como movimentos lentos de rastejo, como através de escorregamentos cíclicos nas estações chuvosas, deixando extensas cicatrizes na paisagem. $O$ alto índice pluviométrico, em torno de $3500 \mathrm{~mm} / \mathrm{ano}$, aliado ao relevo escarpado, favorecem a ocorrência de escorregamentos, fatos esses ques são sempre agravados nos locais onde se manifesta a ação antrópica, quer nas obras viárias, quer nos desmatamentos e ocupações desordenadas como ocorre nos Bairros-Cota da Via Anchieta, onde a população é estimada em 30000 pessoas.

As encostas em geral estão em situação de equilibrio precário (Fator de segurança $\sim 1,0$ ), sendo sua estabilidade diretamente condicionada pelos fatores de natureza geológica, geomorfológica e estrutural, conforme abordado no decorrer do trabalho. Os escorregamentos predominantes são superficiais translacionais de pequena espessura, afetando o solo coluvial, sendo a superfície de ruptura o contacto com o substrato de material saprolítico, o qual por vezes, tem partes envolvidas no processo. Esses escorregamentos afetam tambem zonas de tálus, os quais em alguns casos de cortes rodoviários, apresentaram rupturas rotacionais mais profundas. Localmente ocorrem escorregamentos planares em solos saprolíticos e rochas.

As principais estruturas rúpteis, dispóem-se em padrões concordante ou sub-normal com a direção geral das estruturas regionais $\left(\mathrm{N} 50^{\circ}-60^{\circ}\right.$ e $\left.\mathrm{N} 140^{\circ}-150^{\circ}\right)$, havendo algumas familias secundárias bastante desfavoráveis para a estabilidade. 


\section{ABSTRACT}

Serra de Cubatão, local denomination of Serra do Mar ridge is predominantly constituted by metamorphic rocks of high and medium grade which belong to the Upper Proterozoic Embu and Costeiro Complexes. They include gnaisses, granitegnaisses, schists, phyllites, mylonites, quartzites and carbonates.

Its origin is intimately linked to the origin and development of the Brazilian southeastern coast, which began in the Jurassic/Early Cretaceous with separation of South America from Africa, during the break-up of Gondwana land.

The lithologic contacts in the area are quite lineal and sub-parallel, accompanying the local strike of the Cubatão Fault, $\mathrm{N} 50^{\circ}-60^{\circ}$. That is also the main regional trend of folds, faults, foliations, granitic intrusions, etc.

The alteration profile in the scarps is basically represented by the sequence coluvial soil/residual soil/weathered rock/rock, with several local talus occurrences. The alteration thickness reaches dozens of meters close to the border of the Paulistano Highlands (about $750 \mathrm{~m}$ of altitude), declining in lower altitudes. Below the altitude of $300 \mathrm{~m}$, its thickness is reduced to a few meters and rock appears along the drainage lines and on the slopes.

Along the years the area has been subjected to mass movements related to the geomorphic evolution of the scarp, represented as much as slow movements ("rastejo"), as cyclical landslides in the rainy seasons leaving extensive scars in the landscape. The high pluviometric index, around $3500 \mathrm{~mm} /$ year, allied to the abrupt relief, favor the landslides occurrences, which are always agravated by local anthropic actions, such as road constructions, deforestations and disordered human settlements. One exemple are the Bairros-Cotas of Via Anchieta, with an estimated population of 30000 people.

The slopes in general are in precarious balance (Factor of safety $\sim 1,0$ ). Its stability is directly conditioned by geological, geomorphological and structural factors.

The predominant landslides are thin and superficial, affecting the coluvial soil, with failure surface on the contact with the saprolitic substratum, which can have some of its parts involved in the process. This type of landslides also affects talus zones, but in some cases related to the road cuts, talus present deep circular failures.

Plane failures are local, affecting saprolites and rocks.

The general discontinuities are disposed in patterns following or sub-normal to the general strike of the regional structures $\left(\mathrm{N} 50^{\circ}-60^{\circ} ; \mathrm{N} 140^{\circ}-150^{\circ}\right)$, with secondary families quite unfavourable for the stability of the slopes. 


\section{CAPÍtuLO I}

\section{INTRODUÇÃO}

\section{I.1. HISTÓRICO - OBJETIVOS}

A estabilidade de encostas em ambiente tropical e sub-tropical, como ocorre em nosso país é assunto de interesse técnico-científico e tambem social, na medida em que a ação antrópica, onde ela se verifica é o principal agente deflagrador das instabilizações, ou no mínimo fator agravante das condições do equilíbrio natural.

Se bem que existam algumas controvérsias, o termo encosta é geralmente utilizado para maciços naturais e o termo talude para maciços trabalhados pelo homem. Tal discussão entretanto não é relevante para este trabalho.

No Brasil se destaca a importância do estudo de encostas, ao longo das escarpas serranas que acompanham grande extensão da costa brasileira, notadamente na região sudeste, com a Serra Geral, Serra do Mar e Serra da Mantiqueira.

Cidades litorâneas situadas no sopé da Serra do Mar, como Caraguatatuba, Santos, e Rio de Janeiro, para citar os casos mais notáveis, tem sido ao longo dos anos palcos de instabilizações danosas ao patrimônio publico e trágicas para a população.

Relatos de Cubatão, cujo município abrange parte da serra do mesmo nome, tem sido constantemente citados na bibliografia técnica e na mídia em geral, não só por alguns acidentes localizados, mas principalmente devido ao permanente risco de instabilizações que ameaça os chamados "Bairros-Cota", situados ao longo da Via Anchieta, onde vive uma população de cerca de 30.000 pessoas.

Outras cidades não litorâneas, porem de topografia montanhosa, como Petrópolis, Campos do Jordão e Ouro Preto, para citar 3 casos bem conhecidos, já registram alguns eventos de escorregamentos geológicos, inclusive com vítimas fatais. Convem lembrar que os termos escorregamentos e deslizamentos são geralmente utilizados, sem haver uma diferença clara entre eles.

De modo geral, cidades de grande população, como algumas capitais de Estados, destacando-se Salvador, Recife, São Paulo, Belo Horizonte, apresentam aspectos de riscos geológicos devido às instabilizaçóes provocadas por populações de baixa 
renda que ocupam desordenadamente áreas de encostas de morros, o que resulta em acidentes periódicos, nos períodos de chuvas mais concentradas. Esse mesmo tipo de situação aliás é encontrado em diversas cidades do mundo com população excessiva e de baixa renda, como ocorre em vários paises asiáticos.

Os problemas de instabilidades em encostas estão ligados a uma multiplicidade de fatores naturais, que se iniciam na própria formação geológica do maciço, continuam através de suas evolução geomorfológica e estrutural e se agravam sempre que ocorre a ação antrópica.

Sendo bastante grande a variedade e complexidade desses fatores, não seria possível abordá-los todos detalhadamente uma vez que cada caso de instabilização é um caso particular que deve merecer a atenção do geólogo e do geotécnico.

Entretanto, $O$ assunto merece uma abordagem geral nos seus aspectos principais, bem como observações específicas e concernentes à área pesquisada, sendo esta a proposta do presente trabalho.

O fato de se encontrarem na área de estudo as ligações viárias entre a Grande São Paulo e as cidades de Santos, Cubatão, São Vicente, Guarujá, além do principal porto brasileiro e um importante complexo petro-químico, reforça a conveniência da pesquisa. Como é sabido, tambem essas ligações são periodicamente afetadas por escorregamentos de taludes e encostas.

Convem lembrar que já foi iniciada a construção de uma segunda pista da Rodovia dos Imigrantes no trecho serrano, o que poderá representar novo impacto para a área, com novas instabilizações.

Dentre os inúmeros casos de instabilizações de encostas ocorridos no Brasil, podemos destacar alguns que tiveram consequências trágicas para a população, conforme apresentado na Tabela I.1.1. 
Tabela 1.1.1. Acidentes importantes causados por escorregamentos no Brasil (Augusto Filho, 1994)

\begin{tabular}{|c|c|c|}
\hline LOCAL & DATA & PERDAS SOCIOECONÖMICAS \\
\hline Santos, SP (Mont Serrat) & 1928 & 60 mortes, destruição da Santa Casa de Santos \\
\hline Vale do Paraíba (RJ/MG) & dez/1948 & 250 mortes, destruição de centenas de casas \\
\hline Santos, SP (Mont Serrat) & 1956 & 43 mortes, destruição de 100 casas \\
\hline Rio de Janeiro, RJ & $\operatorname{jan} / 1966$ & 100 mortes \\
\hline Serra das Araras, RJ & jan/1967 & $\begin{array}{l}1200 \text { mortes, destruição de dezenas de casas, rodovias } \\
\text { avariadas, destruição de uma usina hidrelétrica }\end{array}$ \\
\hline Caraguatatuba, SP & $\operatorname{mar} / 1967$ & 120 mortes, destruição de 400 casas \\
\hline Salvador, BA & $a b r / 1971$ & 104 mortes, milhares de desabrigados \\
\hline Campos de Jordäo, SP & ago/1972 & mais de 10 mortes, destruição de 60 moradias \\
\hline Maranguape, CE & $a b r / 1974$ & 12 mortes, destruição de dezenas de casas \\
\hline Lavrinhas, SP & $\mathrm{dez} / 1988$ & 11 mortes, destruição de casas e pontes \\
\hline Cubatão, SP & $\mathrm{jan} / 1988$ & 10 mortes \\
\hline Petrópolis, RJ & fev/1988 & 171 mortes, 1100 moradias interditadas, 5000 desabrigados \\
\hline Rio de Janeiro, RJ & fev/1988 & mais de 30 mortes, destruição.de dezenas de moradias \\
\hline Salvador, BA & jun/1989 & cerca de 100 mortes, destruiçāo de dezenas de moradias \\
\hline Sáo Paulo, SP & out $/ 1989$ & 14 mortes \\
\hline Recife, PE & $\mathrm{jul} / 1990$ & cerca de 10 mortes \\
\hline Blumenau, SC & out $/ 1990$ & cerca de 10 mortes, destruiçāo de várias moradias, pontes e vias \\
\hline Săo Paulo, SP & out/1990 & cerca de 10 mortes \\
\hline Belo Horizonte, MG & jan/fev/1992 & mais de 10 mortes \\
\hline Contagem, MG & $\mathrm{mar} / 1992$ & $\begin{array}{l}36 \text { mortes, destruiçăo de dezenas de moradias, centenas de } \\
\text { desabrigados }\end{array}$ \\
\hline Salvador, BA & $\operatorname{mar} / 1992$ & 11 mortes \\
\hline
\end{tabular}




\section{I.2. LOCALIZAÇÃO}

A área de estudo está situada entre as coordenadas geográficas:

$23^{\circ} 51^{\prime}$ 'a $23^{\circ} 57^{\prime}$ de latitude Sul e 46 $26^{\prime}$ 'a $46^{\circ} 35^{\prime}$ de longitude Oeste de Greenwich, abrangendo aproximadamente $125 \mathrm{~km}^{2}$, conforme apresentado na Figura I.2.1.a.

A sua localização e a base topográfica utilizada, estão indicadas na Figura I.2.1.b.

Abrange um trecho da Serra do Mar, conhecido como Serra de Cubatão, no qual estão situadas as mais importantes ligações viárias entre a Grande São Paulo e a Baixada Santista, ou seja: Via Anchieta, Rodovia dos Imigrantes, Caminho do Mar e ferrovia da ex-FEPASA.

Essas ligaçóes permitem acesso ao porto de Santos e ao complexo siderúrgico $e$ petroquímico de Cubatãos e Piaçaguera, sendo vitais para a economia paulista e do País. Além disso, atendem ao intenso tráfego existente entre a Grande São Paulo e as cidades litorâneas de Santos, São Vicente, Guarujá, Bertioga, Praia Grande, Itanhaém, etc, polos turísticos muito procurados, especialmente nos finais de semana e períodos de férias escolares.

De imediato podemos distinguir 3 feições de relevo distinto, de noroeste para sudeste: Planalto Paulistano, Serra de Cubatão, Planície Costeira.

O rio Cubatão se destaca, atravessando a área de sudoeste para nordeste, acompanhando a direção geral das escarpas da Serra de Cubatão. 


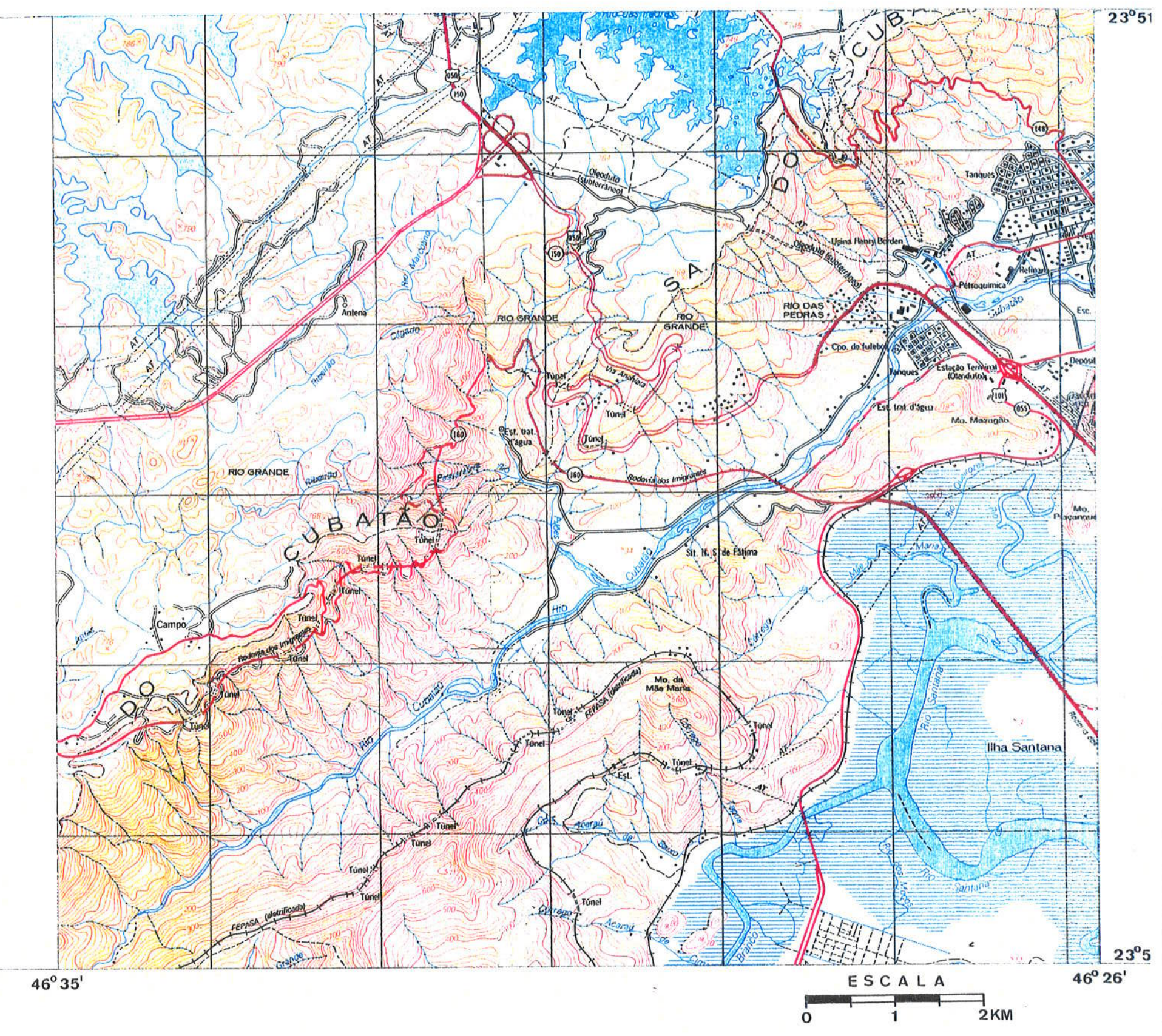

Figura I.2.1.a. Área da pesquisa (IBGE, 1984) 


\begin{tabular}{|c|c|c|}
\hline $\begin{array}{c}\text { Sāo } \\
\text { Paulo }\end{array}$ & Maúa & $\begin{array}{c}\text { Mogi das } \\
\text { Cruzes }\end{array}$ \\
\hline $\begin{array}{c}\text { Riacho } \\
\text { Grande }\end{array}$ & Santos & Bertioga \\
\hline
\end{tabular}

Folhas Santos, Riacho Grande 1:50000 IBGE 1984

ARTICULAÇÃO

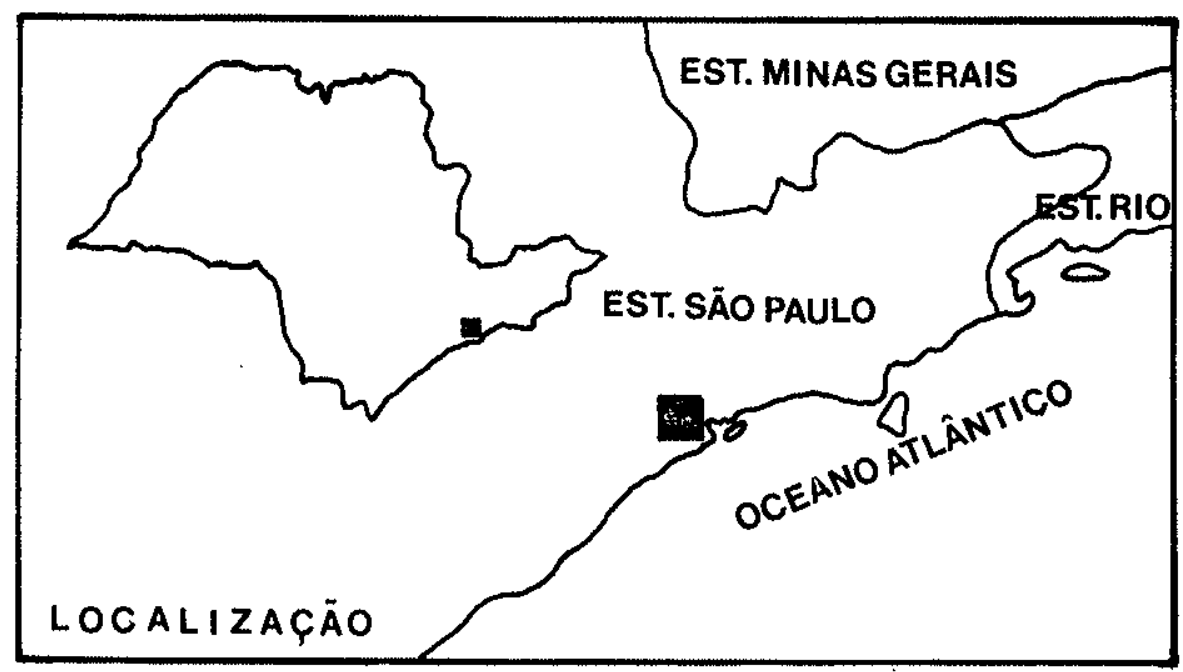

Figura 1.2.1.b. Localização da área e base topográfica 


\subsection{VISÃO GERAL DA ÁREA}

Podemos ter uma visão geral da área, na Imagem I.3.1., que é uma composição RGB das bandas TM 3, 4 e 5 do satélite Landsat 5, processada no Laboratório de Informática-Geológica do IG/USP.

A imagem contem a área da pesquisa, acrescida de uma faixa lateral de aproximadamente $4 \mathrm{~km}$ de largura, no lado leste.

Os aspectos comentados para a figura I.2.1.a., ficam neste caso muito mais visíveis. Em especial a diferenciação do relevo pode ser feita com grande facilidade, sendo nítida a linha da escarpa e tambem o limite da planície costeira.

O rio Cubatão, aparece como um risco preto atravessando a imagem diagonalmente segundo a direção $\mathrm{NE}$, acompanhando aproximadamente a linha da escarpa serrana. Segundo esta mesma direção se alinham as cristas da vertente direita, onde se localiza a ferrovia da ex-FEPASA. Na base desta vertente, um alinhamento indelevel marca o Falhamento do Cubatão.

$\mathrm{Na}$ porção do planalto são bem visíveis as rodovias: Anchieta, Interligação Anchieta-Imigrantes e parte do Caminho do Mar. Na planície (conhecida localmente como Baixada Santista), distinguimos as rodovia Anchieta, Imigrantes e Pedro Taques. Na porção serrana, as rodovias aparecem como linhas azuladas finas e pouco distintas.

As área industriais da PETROBRAS (Refinaria Presidente Bernardes) e a maior parte da área da COSIPA, aparecem no quadrande $\mathrm{NE}$, bem como a área urbana de Cubatão. Áreas urbanizadas de São Vicente aparecem mais ao sul.

São tambem visíveis os terraplenos executados na porção sul da imagem, para efeito industrial e de loteamento urbano, os quais evoluiram bastante nestes últimos anos.

Muitos outros detalhes que podem ser observados na imagem, relativos à geomorfologia, drenagem em geral $e$ alinhamentos estruturais, serão melhor comentados nos capítulos seguintes. 


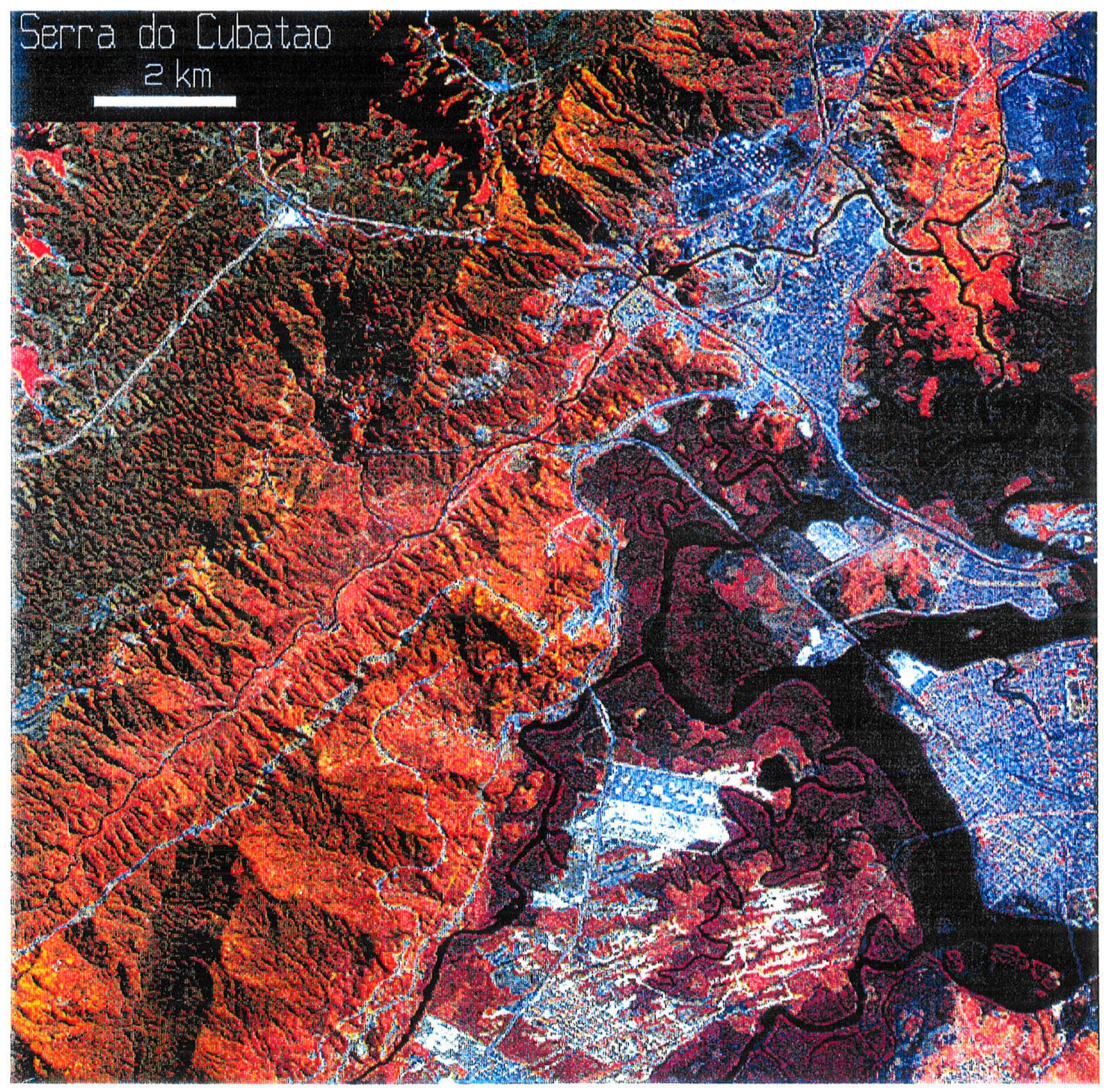

Imagem I.3.1. Visão geral da área (Landsat 5, 1988) 


\subsection{METODOLOGIA - FONTES DE INFORMAÇÃO}

A metodologia utilizada, levando em conta os objetivos do trabalho, foi lastreada na pesquisa bibliográfica e conhecimento de campo do autor, evitando sempre que possivel incorrer em dispersão de dados ou informações não diretamente correlacionáveis ao tema ou à area de estudos.

Inicialmente foi pesquisada a documentação bibliográfica e cartográfica disponível, tanto no sentido de conhecer o "arcabouço geológico-estrutural" regional, como os mapas-base para a área da pesquisa, onde pudessem ser lançados os dados geológicos, geomorfológicos e estruturais.

A base topográfica utilizada, foram as folhas de Santos e Riacho Grande, do IBGE, 1984, na escala 1:50000.

O mapa geológico está totalmente baseado em SADOWSKI $(1974,1993)$, com mudanças na terminologia sugeridas pelo mesmo autor.

O mapa sofreu adaptação da escala, sendo que os levantamentos de campo permitiram ajustar os limites dos tálus e aluvióes bem como determinar atitudes estruturais em pontos escolhidos.

O mapa geomorfológico foi elaborado utilizando a base cartográfica já citada, a partir de fotointerpretação em escritório. Foram usadas as fotografias aéreas executadas pela BASE, 1994, na escala 1:25000, cobrindo toda a área.

Tivemos acesso tambem a algumas fotos da USAF, 1965, na escala 1:20000, estas de melhor qualidade, embora mais antigas, disponíveis apenas para parte da área e naturalmente superadas em termos de ocupação e uso do solo.

O mapa de fotolineamentos, na escala aproximada 1:40000, foi elaborado a partir das fotos aéreas mencionadas, com ajustes por imagens do satélite Landsat 5 , dos anos 1988 e 1994.

Dados estruturais relativos à tectônica rúptil foram coletados localmente, no sentido de caracterizar as direções principais de juntas e falhas.

A riqueza de dados existentes e conhecidos do autor, simplificou de certa forma a tarefa de campo, dificultada pela falta de segurança em vários pontos da área, atualmente frequentados por elementos desocupados e potencialmente perigosos. 


\subsection{ESTUDOS GEOLÓGICOS ANTERIORES}

Diversos autores, em diferentes épocas, desde o século passado, realizaram estudos de interesse técnico e científico específico para a área, abordando aspectos da Geologia, Geomorfologia, Tectônica, etc, trabalhando tanto para universidades como para outras instituições oficiais e privadas.

Além disso, devemos lembrar a realização de vários estudos de Geologia Aplicada, efetuados por geólogos e outros profissionais que trabalharam em projetos e obras ligados a empresas estatais e particulares.

Dentre todos esses trabalhos, podemos listar alguns, por ordem cronológica:

ANDRADA (1820) - os irmãos Andrada, realizaram trabalho pioneiro em sua "Viagem Mineralógica na Província de São Paulo", descrevendo as litologias de Santos e da subida da serra;

DERBI (1857), em trabalho tambem com características de pioneirismo, efetuou caminhamento e descrição da geologia ao longo da Estrada de Ferro Sorocabana;

DE MARTONNE (1935), comparou a Serra de Cubatão com um fenômeno ocorrido no sul do Maciço Central Francês - "O Espinouze". Suas considerações sobre a formação e evolução do relevo na Serra do Mar, não tiveram respaldo posterior;

KNECHT $(1936,1964)$, inicialmente elaborou seções geológicas entre Mairinque e Santos e posteriormente (1964, em Geologia do Estado de São Paulo), com dados complementares, procurou delinear a geologia da área;

MORAES REGO (1940), estudando a Geologia do Estado de São Paulo, interpretou o vale do Cubatão como um sinclinal contendo rochas do Grupo São Roque;

RODRIGUES e NOGAMI ( 1951), elaboraram seção geológica ao longo da Via Anchieta e estudaram escorregamento ocorrido na cota 95; 
GUIMARÃES (1952), registrou diversas ocorrências minerais na região, dentre as quais mármores e calcários magnesianos na Via Anchieta e no sopé da serra;

ALMEIDA (1953, 1964), realizou o primeiro estudo específico sobre falhamento nas áreas dos rios Cubatão e Mogi, sugerindo uma origem de falha para a Serra do Mar, seguida de erosão regressiva da escarpa. Posteriormente, descreveu os fundamentos geológicos do relevo Paulista, sintetizando os conhecimentos sobre a faixa costeira;

AB' SABER (1955), baseado em indícios geomorfológicos, analisou a influência dos falhamentos na modelagem da escarpa serrana, a partir do Cretáceo;

MACHADO FILHO $(1969,1984,1994)$, executou perfis geofísicos preliminares na Serra de Cubatão, relatou situações de risco de populações nas encostas da Via Anchieta e estudou escorregamentos no Caminho do Mar;

SUGUIO e KUTNER (1969), estudaram os sedimentos do Rio Cubatão, detalhando suas características e realizando análises estatísticas;

COUTINHO (1972), realizou estudos petrográficos do falhamento do Cubatão, tentando estabelecer sua correlação regional;

PAIVA e PONÇANO (1972), visando projeto de barragem, estudaram a geomorfologia do vale do Cubatão;

CRUZ (1975, 1990), realizou estudos geomorfológicos sobre a evolução de vertentes em escarpas da Serra do Mar;

MACHADO FILHO e HESSING (1976), descreveram estudos geológicos realizados para a implantação da Rodovia dos Imigrantes;

SADOWSKI $(1974,1977,1993)$, elaborou mapa geológico e analisou a tectônica da Serra do Cubatão. Elaborou diversos estudos sobre a região, incluindo a reativação tectônica e a megafalha do Cubatão; 
SADOWSKI e MOTIDOME (1987), descreveram os principais falhamentos brasileiros e suas características, incluindo a Falha de Cubatão;

TATIZANA, OGURA, CERRI e ROCHA (1987), analisaram a correlação entre chuvas e escorregamentos na Serra do Mar, elaborando curva representativa das condições-limite dos escorregamentos;

WOLLE $(1986,1988)$, estudou os escorregamentos translacionais na Serra do Mar, analisando a influência da poluição ambiental e elaborando curva mostrando a variação do fator de segurança com o desmatamento;

RODRIGUES (1992), descreveu aspectos geotécnicos de massas coluviais existentes na Serra de Cubatão. 


\section{CAPÍtULO II}

\section{ARCABOUÇo GEOLÓGICO-TECTÔNICO REGIONAL}

\section{II.1. GERAL}

A área da pesquisa se insere no contexto do "Sistema Rift do Este Brasileiro", estudado por CHANG et al (1992), o qual foi denominado pela sigla EBRIS ("The East Brasilian Rift System"). O termo rift, simplificado de "rift valleys" (GREGORY, 1894), designa os arqueamentos da crosta onde a zona central sofreu abatimento, formando vales de subsidência de paredes paralelas, alongadas e íngremes.

O EBRIS constitue na verdade, o segmento setentrional do "Sistema Rift do Atlântico Sul", estudado anteriormente por ALMEIDA (1976) e depois por RICCOMINI (1989), o qual se formou durante a era Mesozóica, separando a América do Sul e África. Esses dois grandes blocos faziam parte originalmente do supercontinente do Gondwana, que na era Paleozóica englobava tambem Índia, Austrália e Antártida.

O EBRIS teria se desenvolvimento com a expansão da litosfera no período Jurássico/Início do Cretáceo, conforme concordam vários autores como ESTRELLA (1972), HASUI (1978) e ASMUS $(1978,1982)$.

A separação dos blocos da América do Sul e África, provocou a formação de dois tipos de margens continentais bastante diferentes na borda brasileira:

- A margem equatorial norte, resultante de deslocamentos de carater transcorrente entre os blocos continentais, com o desenvolvimento de bacias onde predominam deformações cisalhantes complexas;

- A margem este, formada a partir do desenvolvimento do sistema EBRIS e resultante de deslocamentos crustais de carater extensivo.

Ao longo desta margem este brasileira, desenvolveram-se 6 bacias continentais principais:

Pelotas, Santos, Campos, Espírito Santo, Bahia Sul e Sergipe-Alagoas.

Considera-se tambem integrante do sistema EBRIS, os grabens intracontinentais do Recôncavo, Tucano e Jatobá.

Pesquisas elaboradas por vários autores e compiladas por CHANG et al (1992), mostram que na região sudeste, existe uma tendência geral dos grabens e horsts que formam o sistema de rifts, a se alinharem segundo a direção NE e NNE, 
aproximadamente sub-paralelos aos lineamentos principais do embasamento, conforme apresentado na Figura II.1.1.

Nota-se na figura, que existe certa discrepância entre os dados obtidos no continente em imagens de radar e os interpretados a partir de levantamentos geofísicos nas bacias.

Observa-se ainda que na porção costeira continental em frente à bacia de Santos, na qual temos maior interesse, as direções principais de lineamentos estão entre $\mathrm{N} 55^{\circ}-60^{\circ} \mathrm{E}$, havendo um conjunto subsidiário entre $\mathrm{N} 45^{\circ}-55^{\circ} \mathrm{W}$.

O embasamento costeiro brasileiro, mostra indícios de evolução desde o Arqueano, tendo sido afetado por três grandes eventos tectônico-magmáticos precambrianos:

- O mais antigo, denominado Jequié, ocorreu no Arqueano (2700 - 2600 Ma);

- O intermediário, denominado Tranzamazônico, no início do Proterozóico (2200 - $1800 \mathrm{Ma}$ );

- O último, denominado Brasiliano, teve lugar no final do Proterozóico, extendendo-se até o início do Paleozóico (700 - $500 \mathrm{Ma}$ ).

No último desses grandes eventos, tambem conhecido como Ciclo Brasiliano, a placa brasileira foi totalmente reestruturada, mantendo-se desde então basicamente estável, até ocorrer a separação do supercontinente Gondwana, na era Mesozóica, quando houve o desenvolvimento do Sistema Rift do Atlântico Sul, conforme já mencionado.

No escudo Atlântico, ao longo da margem oriental brasileira (ALMEIDA et al, 1977), podem ser distinguidas 3 grandes províncias precambrianas, (CORDANI et al, 1984; SCHOBBENHAUSS et al, 1984). Figura II.1.2.

- Ribeira;

- Atlântico;

- Sergipana.

Dentre essas províncias, tem maior interesse para este trabalho a do Ribeira, tambem chamada Mantiqueira por ALMEIDA e HASSUI (1985). 


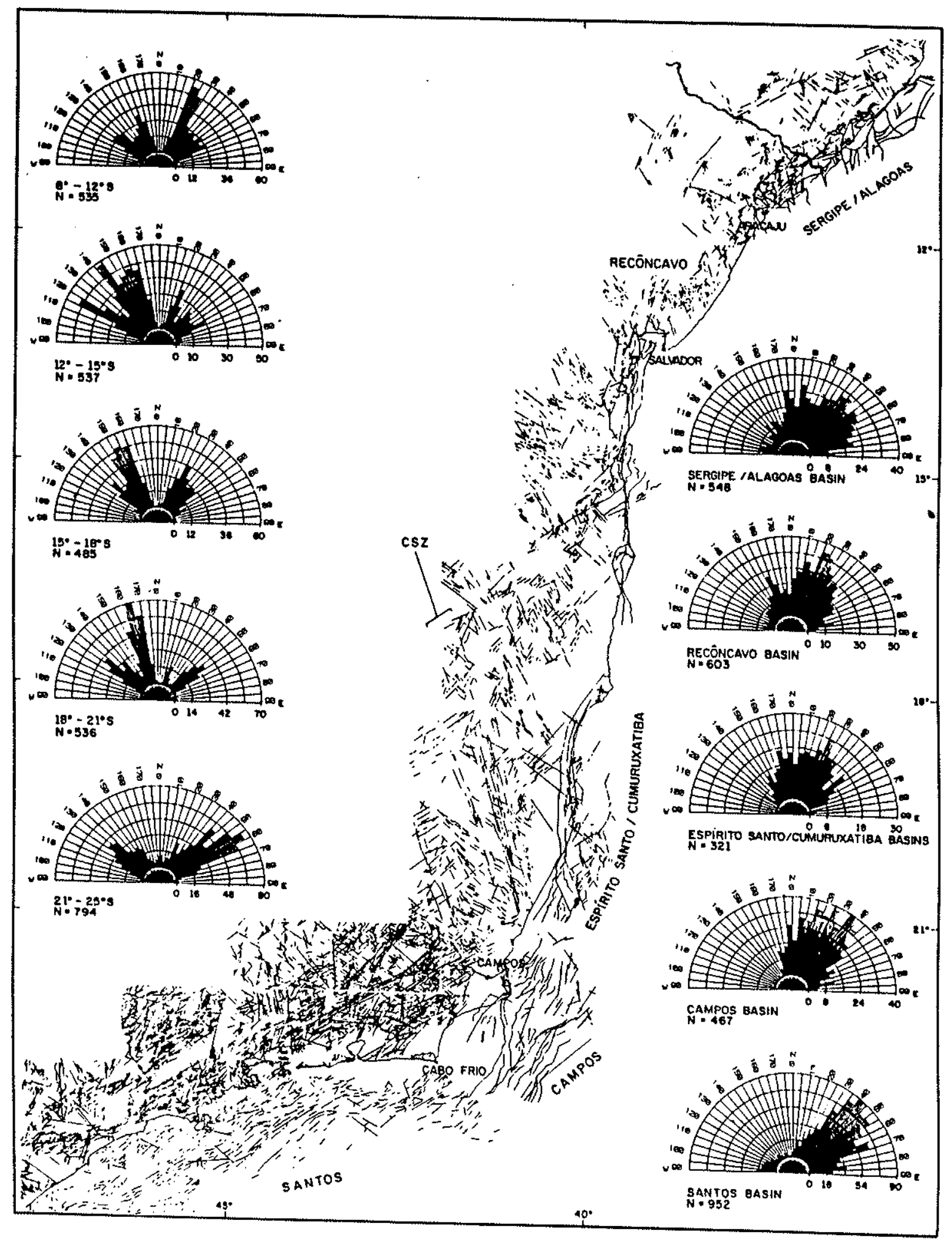

Figura 11.1.1. Lineamentos ao longo da margem este brasileira (Chang et al, 1992). Os lineamentos do embasamento continental estão baseados em imagens aéreas de radar. Os lineamentos das bacias costeiras foram compilados a partir de mapas basais sísmico-estruturais, exceto para a Bacia de Santos onde se basearam em levantamentos aero-magnéticos, podendo neste caso refletir mais o magnetismo mineral do embasamento do que as estruturas de rift da bacia. 


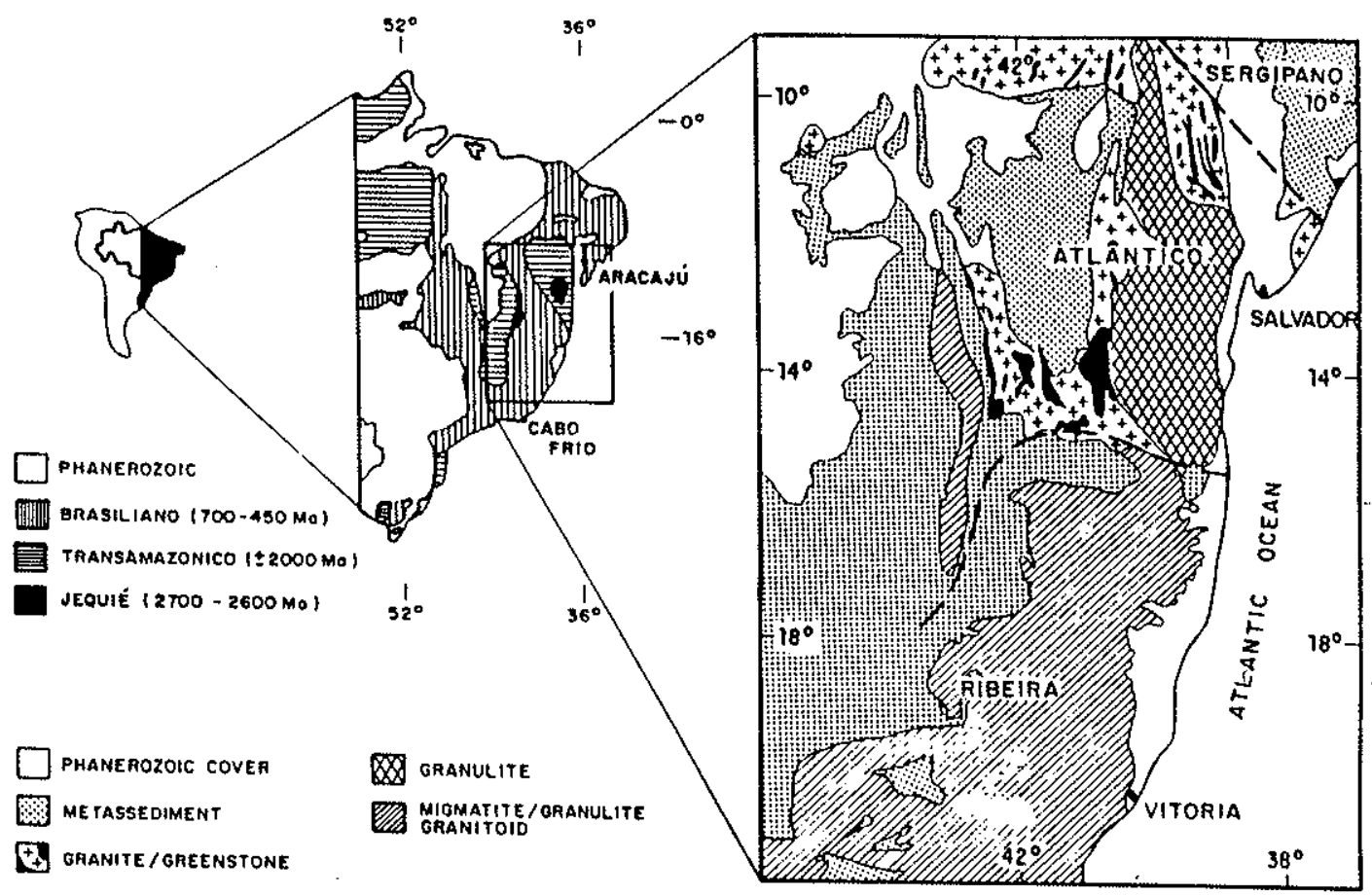

Figura II.1.2. Províncias do embasamento do escudo precambriano brasileiro (Cordani et al, 1984) 


\section{II.2. ZONA DO FALHAMENTO DE CUBATÃO}

A Província Ribeira, na qual temos maior interesse por englobar a área da pesquisa é caracterizada por rochas extremamente afetadas pelo metamorfismo e deformação brasilianos, recortadas por intenso cisalhamento transcorrente associado aos estágios de convergência de blocos continentais, no final do Proterozóico e início do Paleozóico.

$\mathrm{Na}$ área em questão, gerou-se um sistema de falhamentos designado "Sistema de Megafalhas de Cubatão-Alem Paraiba" (SADOWSKI e MOTIDOME, 1987; SADOWSKI, 1991), ou "Sistema de Cisalhamento do Sudeste" (ENDO e MACHADO, 1993).

O Sistema de Megafalhas Cubatão (Figura II.2.1), engloba extensas zonas de cisalhamento subparalelas com direções variando de $\mathrm{N} 50^{\circ} \mathrm{E}$ a $\mathrm{N} 70^{\circ} \mathrm{E}$.

Esse sistema se estende desde o Oceano Atlântico até a borda S-SE do Estado de Minas Gerais, por cerca de $300 \mathrm{~km}$ de largura, se considerarmos englobadas as cunhas de empurrão Socorro-Guaxupé, ou, por $150 \mathrm{~km}$ de largura, se considerarmos apenas sua extensão até o Falhamento de Jandiuvira, na borda da cunha de Socorro.

O sistema se mantem ativo desde o Proterozóico Superior, uma vez que existem indícios de rochas ígneas afetadas desde esse período até o Mesozóico, além de várias reativações posteriores afetando sedimentos Cenozóicos (SADOWSKI, 1977; 1991; RICCOMINI, 1989).

Conforme pode se observar na figura, o Sistema Cubatão apresenta uma zona central de falhamento principal, constituida pelo alinhamento de três segmentos de falhas: Lancinha-Itapeúna, Cubatão e Além Paraiba. O comprimento visível no embasamento exposto é de $800 \mathrm{~km}$, admitindo-se que se estenda tambem sob a Bacia do Paraná por mais $1300 \mathrm{~km}$, totalizando portanto mais de $2000 \mathrm{~km}$ (ZALAN, et al 1987). 


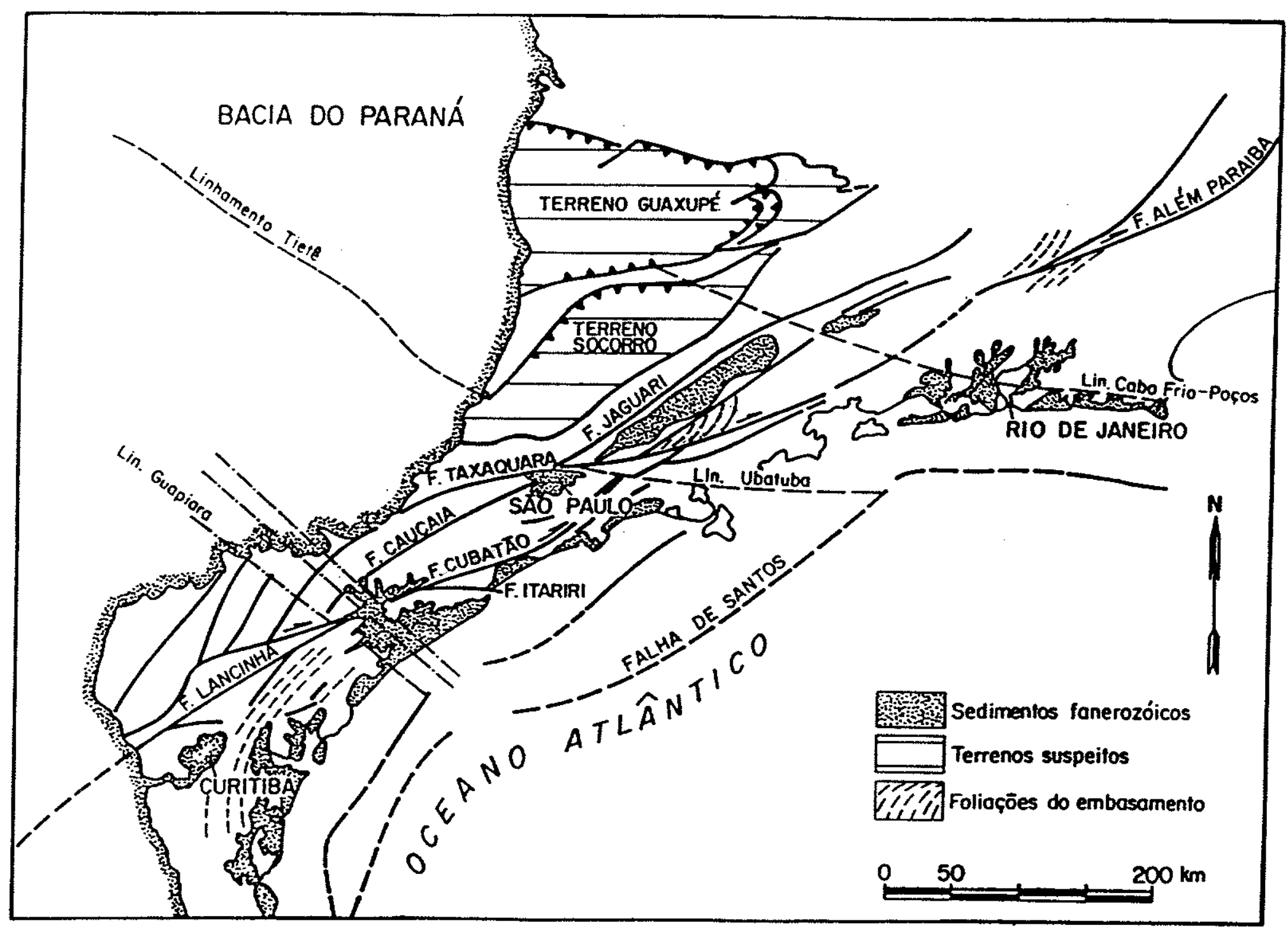

Figura 11.2.1. Sistema de Megafalhas Cubatão (Sadowski, 1991) 
O segmento Cubatão desse sistema, na área da pesquisa, encontra-se associado a uma faixa de metassedimentos de baixo grau, separando as rochas cle alto e médio grau de metamorfismo dominantes no Complexo Costeiro, das consideradas de médio grau de metamorfismo do Bloco Juquitiba (HASUI, 1973, 1984; HASUI e SADOWSKI, 1976).

O falhamento foi considerado basicamente transcorrente dextral (EGYDIO DA SILVA et al, 1982), sendo que nas cercanias de Santos apresenta alem das transcorrências, feições de acavalamento (SADOWSKI, 1974, 1991).

Esses autores, associaram a cinemática da Falha de Cubatão a um sistema de juntas e falhas menores, conforme ilustrado na Figura II.2.2.

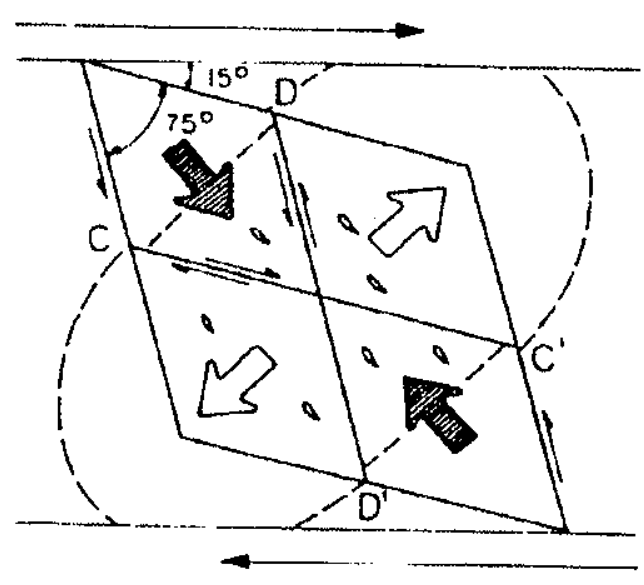

Figura II.2.2. Sistemas de juntas associadas às grandes transcorrências (Egydio da Silva, 1982) 


\title{
CAPÍTULO III
}

\section{GEOLOGIA DA ÁREA}

\section{III.1. ESTRATIGRAFIA.}

\author{
III.1.1. Litologia
}

A área é constituida predominantemente de rochas metamórficas dos Complexos Embu e Costeiro do Proterozóico Superior (HASUI e OLIVEIRA, 1984).

O mapa geológico da área é apresentado na Figura III.1.1.1.

A situação da área e a articulação das folhas IBGE são mostradas na Figura III.1.1.2.a.

A seção geológica A-A', indicada no mapa geológico é mostrada na Figura III.1.1.2.b.

O grau de metamorfismo dessas rochas é variável, desde as de alto grau situadas no Complexo Costeiro a SE, até as consideradas de médio grau do Bloco Juquitiba a NW. Separando-as, nítidamente, está o alinhamento da Falha de Cubatão, associada a metassedimentos de baixo grau.

Podemos estabelecer a seguinte distribuição, numa ordem cronológica começando pela mais antiga:

- Rochas do Complexo Costeiro, conforme terminologia usada por HASUI e SADOWSKI, 1976 e HASUI (1984), aflorantes a sudeste da Falha do Cubatão:

- Gnaisses bandados com hornblenda, biotita, plagioclásios e quartzo;

- Granito-gnaisses com porfiróides de microclina

- Milonito-gnaisses.

- Rochas Associadas ao Falhamento do Cubatão:

- Quartzitos sacaróides;

- Granada-clorita-biotita-xistos, mármores e filonitos cataclasados, com faixas milonitizadas nos contactos. 
- Rochas do Bloco Juquitiba, aflorantes a noroeste da Falha do Cubatão:

- Calco-silicatadas;

- Granada-silimanita-micaxistos, cloritizados e migmatizados;

- Muscovita-biotita-xistos e quartzo-xistos, alternados com silimanita, localmente migmatizados;

- Granito-gnaisses granatíferos;

- Milonito-gnaisses bandados, com intercalações quartzíticas e calco-silicatadas. 


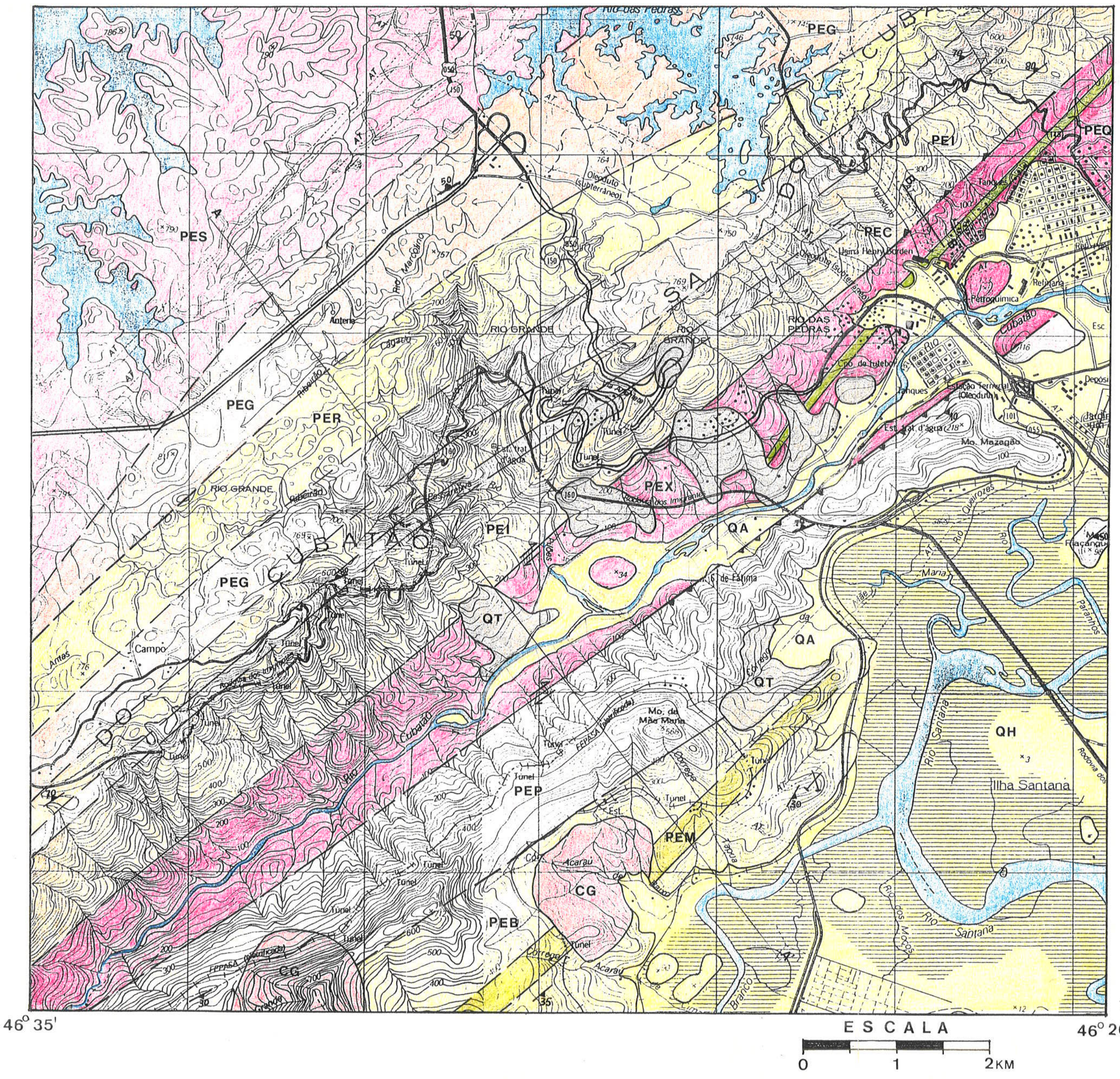

$23^{\circ} 51^{\prime}$

MAPA GEOLÓGICO

LEGENDA

QUATERNÁRIO
QA $\square$ ALUVIİOO
QH $\square$ HOLOCENO MARINHO
QT TALUS

CAMBRIANO-PRECAMBRIANO SUPERIOR

CG GRANITOS PóS-TECTÓNICOS.

PRÉCAMBRIANO

PEI $0 \begin{aligned} & \text { MILONIO-GNAISESE, BANDADOS. COM } \\ & \text { INIFRC. QUARTIIIICASE CALCO-SIICAT. }\end{aligned}$

PEG $\square$ GRANITO-GNAISSES GRANATIFEROS.

PES 0 MUSCOVIIA-BIOIIAA-XISIS E QUARRIO-

PER $\square$ GRANADA-SILIMANITA-MICAXIITOS,

PEC $\square$ CAICO-SHLCAIAdAs

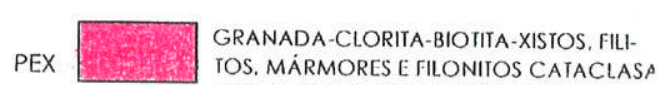

PEQ QUARTIIOS SACARÓIDES

PEM $\square$ MILONIIO-GNAISSES

PEP $\square$ GRANIO-GNAISES COM PORFIRÓIDES

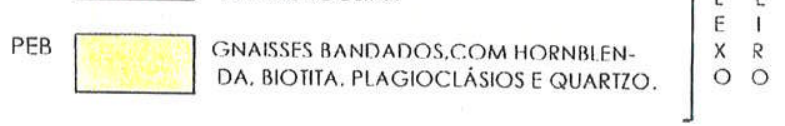

CONVENÇŌES

= contacto geológico observado e inferido

Falha transcorrente

4 Falha reversa

\. xistosidade e foliação

×r Rodovia e efrrovic

$\longrightarrow$ Seção geológica

Figura III.1.1.1. Mapa Geológico
(baseado em Sadowski, 1974, 1992) 


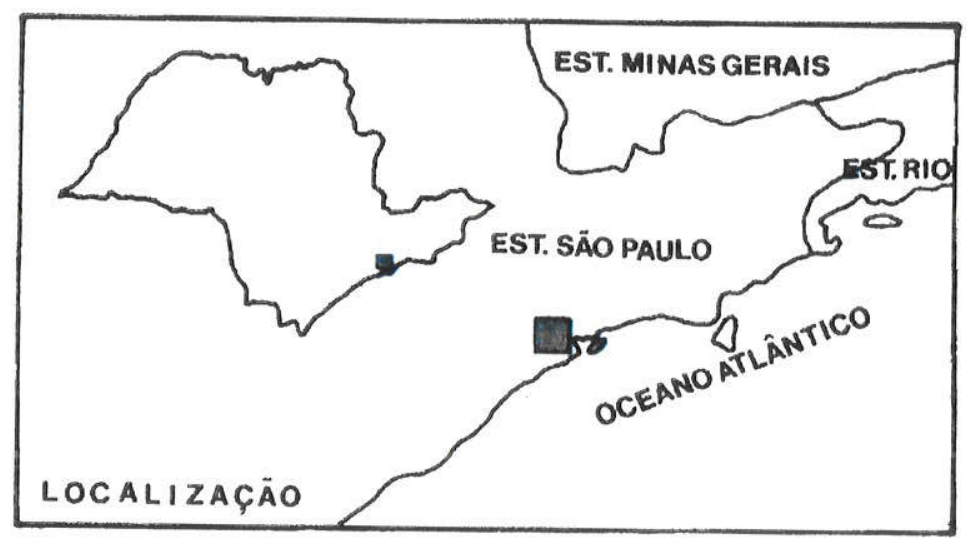

\begin{tabular}{|c|c|c|}
\hline $\begin{array}{c}\text { Säo } \\
\text { Paulo }\end{array}$ & Maus & $\begin{array}{c}\text { Mogi das } \\
\text { Cruzes }\end{array}$ \\
\hline $\begin{array}{c}\text { Riacho } \\
\text { Grando }\end{array}$ & Santos & Bertioga \\
\hline
\end{tabular}

Folhas Santos, Riacho Grande 1:50000 IBGE 1984

ARTICULAÇĀO

Figura III.1.1.2.a. Situação da área e articulação das folhas IBGE
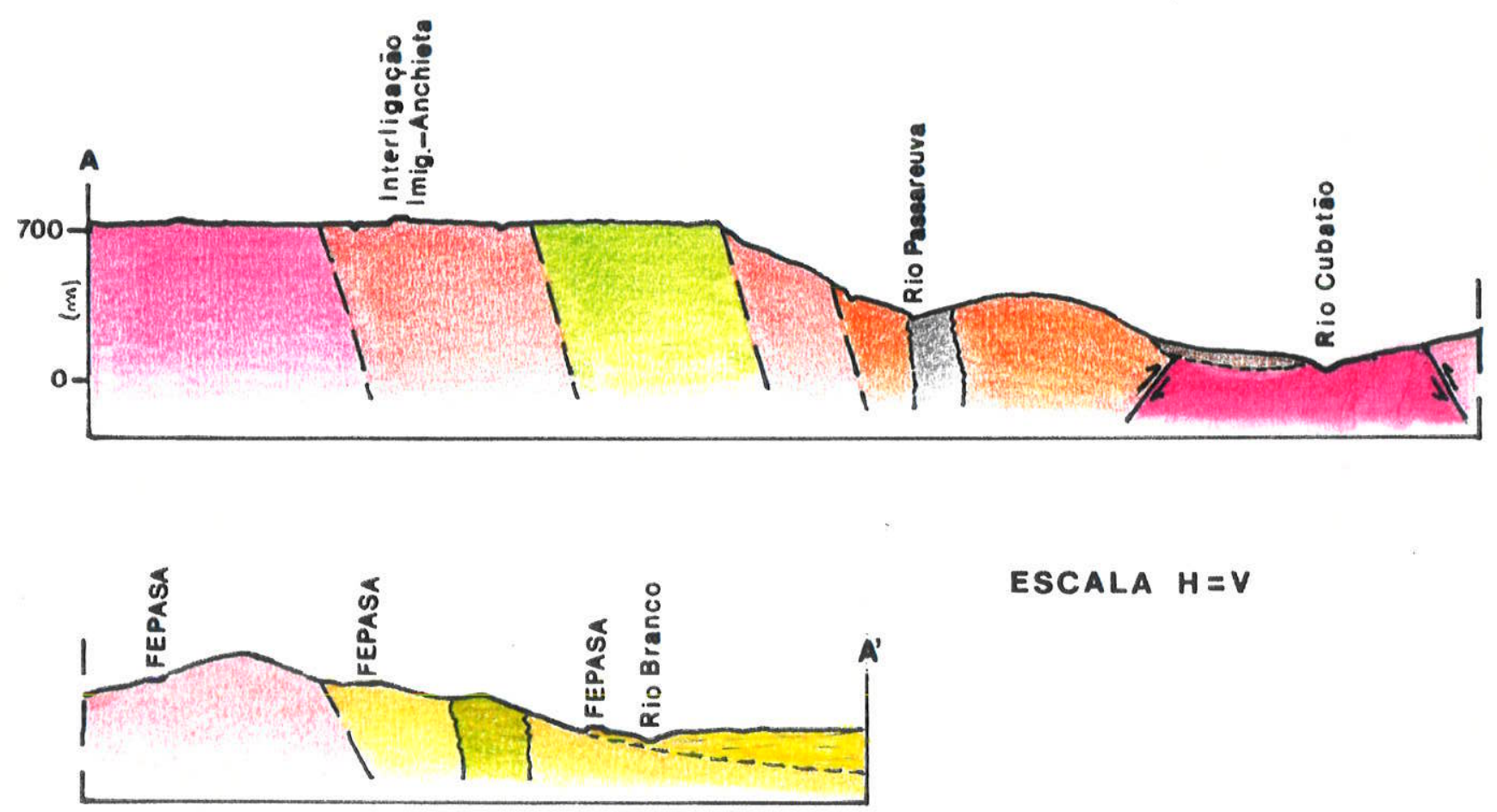

ESCALA $H=V$

Figura III.1.1.2.b. Seção Geológica A-A' 
As relações espaciais da faixa de metassedimentos do vale do Cubatão com as rochas do Bloco Juquitiba, podem ser observadas com mais detalhes na seção geológica B-B', executada no quadrante $\mathrm{NE}$ da área, junto ao aqueduto da Usina Henry Borden (Figura III.1.1.3.).

As rochas existentes na área, apresentam-se em diferentes estágios de alteração, que variam com a litologia. Entretanto, de maneira geral são mais intensos junto ao Planalto Paulistano e vão decrescendo à medida que se desce em cota. Abaixo da cota $350 \mathrm{~m}$, os afloramentos de rocha sã tornam-se sistemáticos nos talvegues.

Sabe-se que na região do planalto essa alteração atinge mais de uma centena de metros de profundidade, de acordo com levantamentos geofísicos (GEOTÉCNICA, 1968).

Dois corpos granitóides se destacam na parte sul, alinhados com outros corpos semelhantes aflorantes fora da área, segundo uma direção geral NE.

Constituem "stocks" circunscritos, ao que tudo indica pós-tectônicos, de idade Cambriano-Precambriano Superior.

A intrusão desses granitóides parece estar estreitamente relacionada com $\circ$ Falhamento de Cubatão, o qual teria criado uma faixa de maior permeabilidade da crosta, possibilitando a subida do magma (SADOWSKI, 1974).

Vários corpos de tálus ocorrem na faixa central da área, acompanhando a linha geral da escarpa serrana, a maioria situada na vertente esquerda do Rio Cubatão. Os corpos maiores se encontram nas cotas mais baixas se estendendo até o vale, enquanto outros corpos menores localizados em cotas mais altas, ocupam depressões locais do embasamento.

Os tálus são formações geológicas acumulativas, recentes e instáveis, de idade Quaternária, com uma composição heterogênea e representativa das diversas litologias aflorantes na serra, nas cotas superiores.

Sào compostos por fragmentos rochosos angulosos a semi-arredondados, com dimensões variando de centimétricos a decimétricos, por vezes com blocos atingindo $1,5 \mathrm{~m}$ a $2,0 \mathrm{~m}$ de diâmetro. Esses fragmentos estão imersos numa matriz mais fina, areno-silto-argilosa. A proporção dos componentes é muito variável, dependendo do corpo de tálus, havendo tambem variações locais num mesmo corpo (MACHADO FILHO, 1976, 1984). 
Ao longo da faixa serrana, recobrindo as rochas precambrianas, ocorrem sedimentos holocênicos delgados (solos coluviais), não representados no mapa geológico, os quais sustentam a vegetação das encostas (RODRIGUES, 1992).

Esses solos são areno-silte-argilosos ou silte-argilosos, com coloração variando do marrom médio ao marrom-acinzentado e possuem espessura geralmente inferior a $1,5 \mathrm{~m}$. Ocorrem ao longo de toda a faixa, ocupando os espigóes até "meia-encosta" e desaparecendo junto aos talvegues.

Esses solos coluviais possuem grande importância no que se refere à estabilidade superficial das encostas, conforme será comentado no Capítulo IV.

No vale do rio Cubatão, ocorrem aluviões holocênicos continentais. São sedimentos grosseiros, formados por seixos e matacões que representam bem as litologias da região. Seus diâmetros variam de centimétricos até $2,0 \mathrm{~m}$, entremeados por areias grosseiras. (SUGUIO, 1969).

Tratando-se de um rio caudaloso, as frações mais finas (silte e argila) não se mantem, pois são carregadas em suspensão.

Na porção SE da área, já na planície costeira, se fazem presentes os sedimentos quaternários marinhos, representados por sucessóes de areias claras e argilas escuras orgânicas, com espessuras variáveis, mas de modo geral crescente em direção ao mar. 


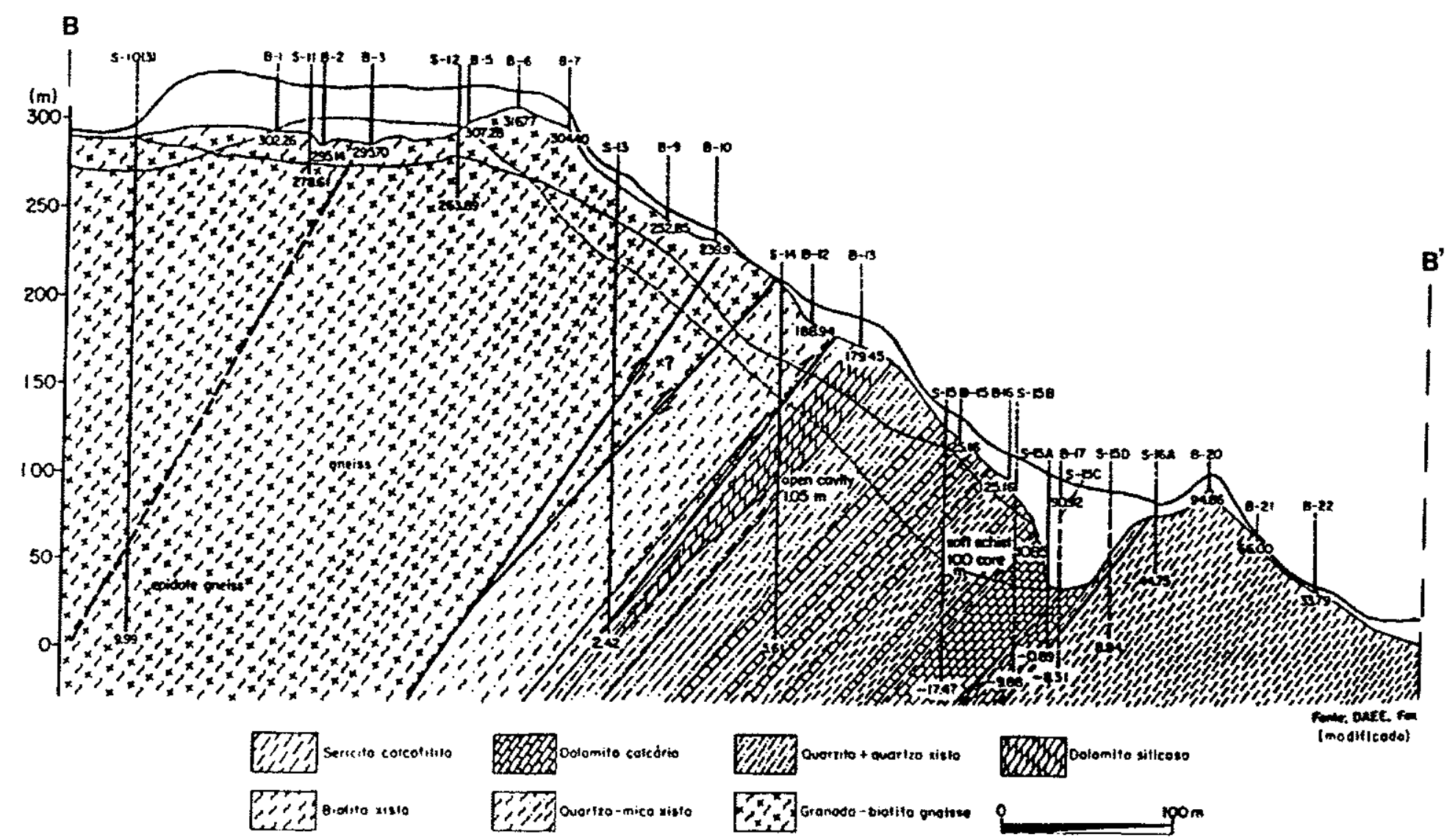

Figura III.1.1.3. Seção B-B': relações espaciais da faixa de metassedimentos do vale do Cubatão, com as rochas do Bloco Juquitiba (Sadowski, 1991) 


\section{III.1.2. Relações de Contacto.}

Conforme pode ser observado no mapa geológico, os contactos entre as várias litologias da área, são bastante lineares e sub-paralelos, acompanhando a direção geral do Falhamento de Cubatão, em torno de $\mathrm{N} 55^{\circ} \mathrm{E}$.

A zona do Falhamento de Cubatão, conforme já citado anteriormente, está preenchida por metassedimentos de baixo grau e separa nítidamente as rochas do Complexo Costeiro das do Bloco Juquitiba.

Os contactos dos metassedimentos costumam ser bem determinados, o mesmo não acontecendo com todas as litologias ao norte e ao sul da Falha, onde podem apresentar aspecto aparentemente gradacional devido terem sido afetadas por intenso cisalhamento dúctil.

Quanto às intercalações de quartzito e calco-silicatadas, formam lentes ou faixas bem alinhadas dentro das outras rochas, apresentando contactos geralmente bruscos e bem determinados.

Os dois corpos granitóides que aparecem no sul da área, possuem contactos fechados, cortando discordantemente os contactos lineares do Complexo Costeiro. A intrusão desses granitos parece estar estreitamente relacionada com o falhamento do Cubatão. De fato, esses corpos, tanto na área como fora dela, formam manchas isoladas que se dispõe paralelamente à direção da falha.

No vale do Cubatão, os aluvióes holocênicos tem seus limites muito bem determinados, a não ser em seus contactos com os talus, onde existem áreas de interpenetração.

Os sedimentos marinhos tiveram seus contactos delineados com base na topografia, sendo visiveis em fotos aéreas.

$\mathrm{Na}$ verdade, pode ocorrer nesses limites uma transição a partir de sedimentos continentais não representados no mapa (solos coluviais), ou mesmo sedimentos aluviais. 


\section{III.2. ESTRUTURAS.}

\section{III.2.1. Estruturas Dúcteis.}

Algumas estruturas primárias do tipo bandamentos e acamamentos residuais podem ser encontradas preservadas em rochas da região.

Entretanto, as estruturas mais frequentes $e$ importantes são as tectônicas secundárias, dúcteis ou rúpteis.

Dentre as estruturas dúcteis, se destacam as penetrativas, foliações e lineações, visíveis em afloramentos e tambem em escalas menores, até a microscópica. Ocorrem tambem estruturas de menor abrangência espacial como dobras e "boudins", estes últimos representando feições de transição dúctil-rúptil. Fotografias III.2.1.1. e III.2.1.2.

Existem várias gerações de foliações afetando as rochas da área pesquisada, sendo que a mais proeminente corresponde à foliação de transposição ondulada, em amplos anticlinórios e sinclinórios, ao longo de eixos de dobramento $\mathrm{N} 50^{\circ}-60^{\circ} \mathrm{E}$ (SADOWSKI, 1977). Essa foliação de transposição ondulada é intensificada próximo às zonas de falha, confundindo-se com a própria foliação milonítica, na região de maior deformação das faixas miloníticas do Cubatão. Ela constitue planos que condicionam menor resistência mecânica das rochas. Nesses planos, por vezes pode-se observar o estiramento e achatamento de "boudins", tanto em pegmatitos como em camadas de rochas calco-silicatadas.

As foliações anteriores à transposição, indicam a existência de fases de dobramentos anteriores, encontrando-se frequentemente onduladas $e$ se entrecortando.

Não há para o presente trabalho, interesse em aprofundamento desses aspectos.

Foram mencionadas 3 fases de deformações penetrativas no Bloco Juquitiba (HASUI e SADOWSKI, 1976), alem da existência de núcleos precambrianos ainda mais intensamente deformados dentro das rochas do Complexo Embu, nas proximidades das escarpas da Serra do Mar.

Nas rochas do Complexo Costeiro, são mencionadas evidências de 2 fases de dobramentos penetrativos, nas rochas supostamente brasilianas (SADOWSKI $e$ MOTIDOME, 1987), não entrando os autores em detalhes quanto à deformação de núcleos granulíticos fora da área da pesquisa. 


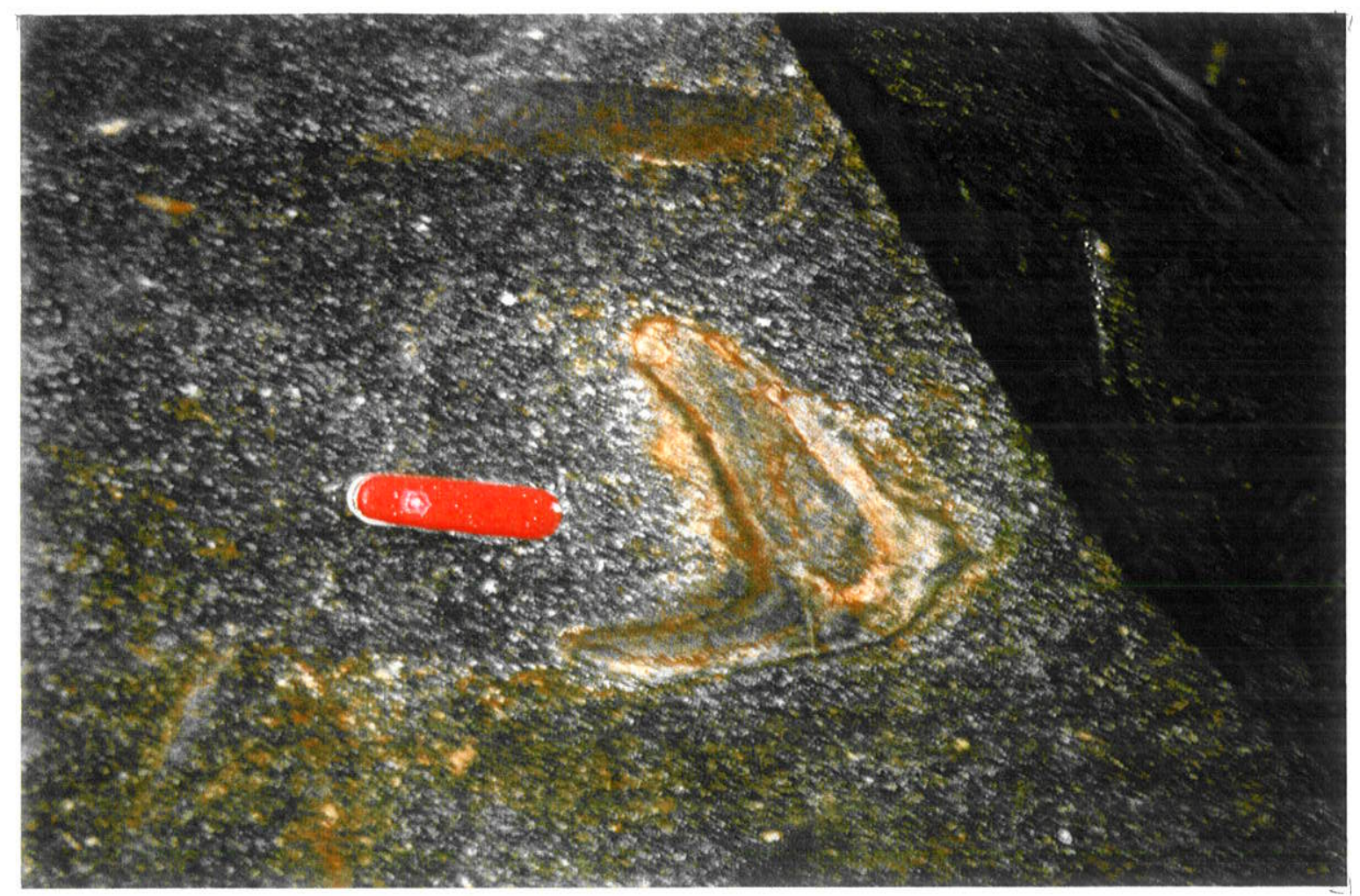

Fotografia III.2.1.1. Dobra em zona de cisalhamento dúctil

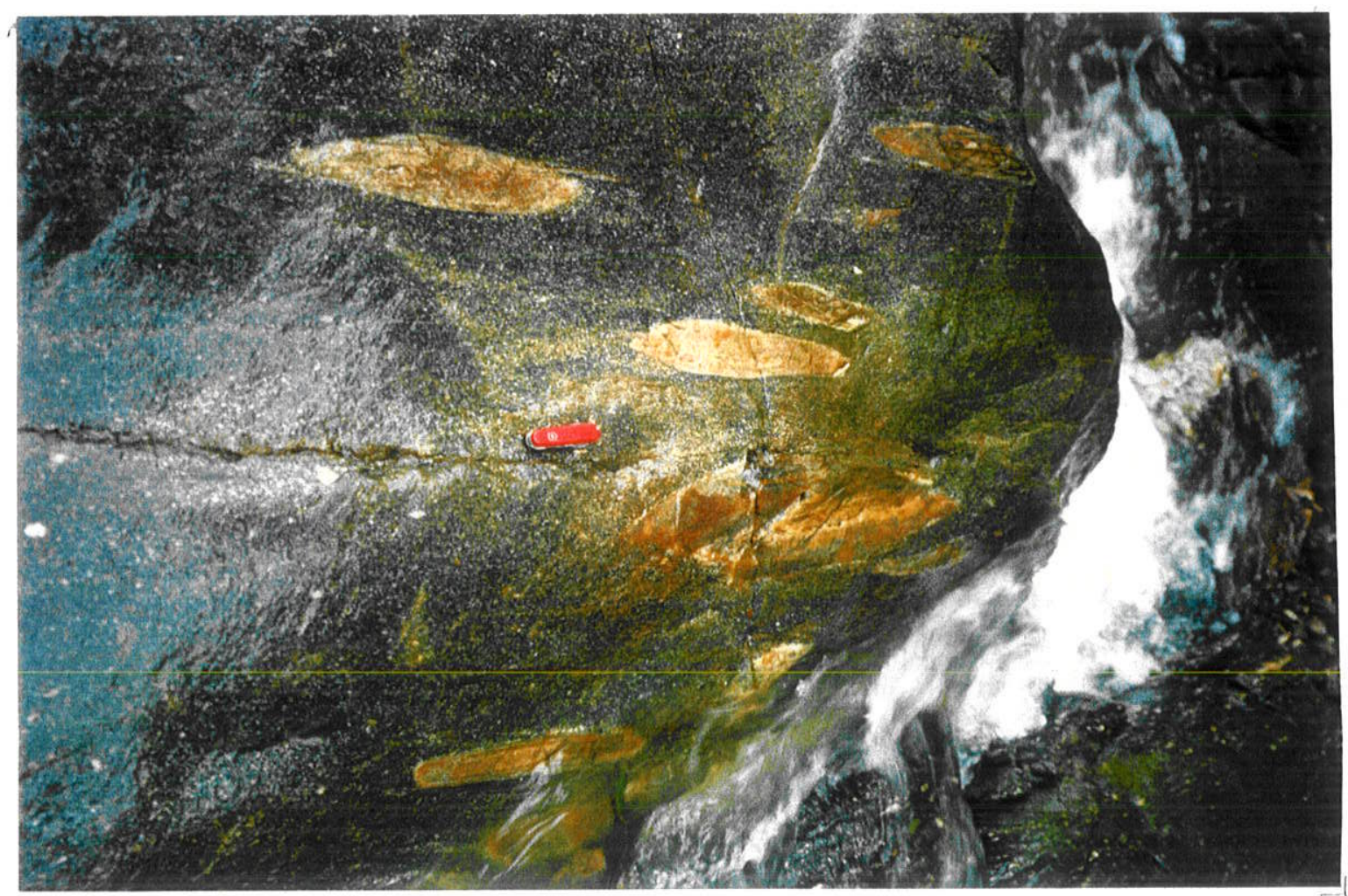

Fotografia III.2.1.2 Boudins em zona de cisalhamento dúctil-rúptil 
III.2.2. Estruturas Rúpteis - Fotolineamentos

As estruturas rúpteis são claramente determinantes das drenagens superficiais (e sem dúvida tambem da subterrânea como discutiremos mais adiante), em toda a área, se distribuindo segundo um padrão ditado pelos grandes falhamentos que afetaram a região, condicionadas em parte pelas anisotropias e sistemas de juntas menores resultantes de deformações Neoproterozóicas.

A estabilidade dos blocos está íntimamente ligada às estruturas rúpteis, daí a importância de estudar a sua distribuição na área.

Realizamos um estudo dos fotolineamentos, cujo mapa esquemático é apresentado na Figura III.2.2.1. e permite uma visão dos padrões dessas estruturas observadas no plano horizontal.

Os fotolineamentos foram obtidos por observação estereoscópica em fotografias aéreas nas escalas 1:25000 (BASE, 1994) E 1:20000 (USAF, 1965), complementada por consulta a imagens do LANDSAT $5(1988,1995)$.

Os fotolineamentos foram estudados através de diagramas de distribuição de frequências do tipo rosáceas, com intervalos angulares de $10^{\circ}$, utilizando-se o programa "Rockware, v. 2.0", tentando-se estabelecer áreas diferenciadas em relação aos padrões de distribuição.

Foram feitas inúmeras tentativas de separação de áreas, após o que optamos por 4 áreas que se mostraram aparentemente mais interessantes e cujas rosáceas são apresentadas nas figuras a seguir:

Área do Planalto: Figura III.2.2.2.

Área da Serra e Vale do Cubatão: Figura III.2.2.3.

Área A, na parte SW: Figura III.2.2.4.

Área B, na parte NE: Figura III.2.2.5. 


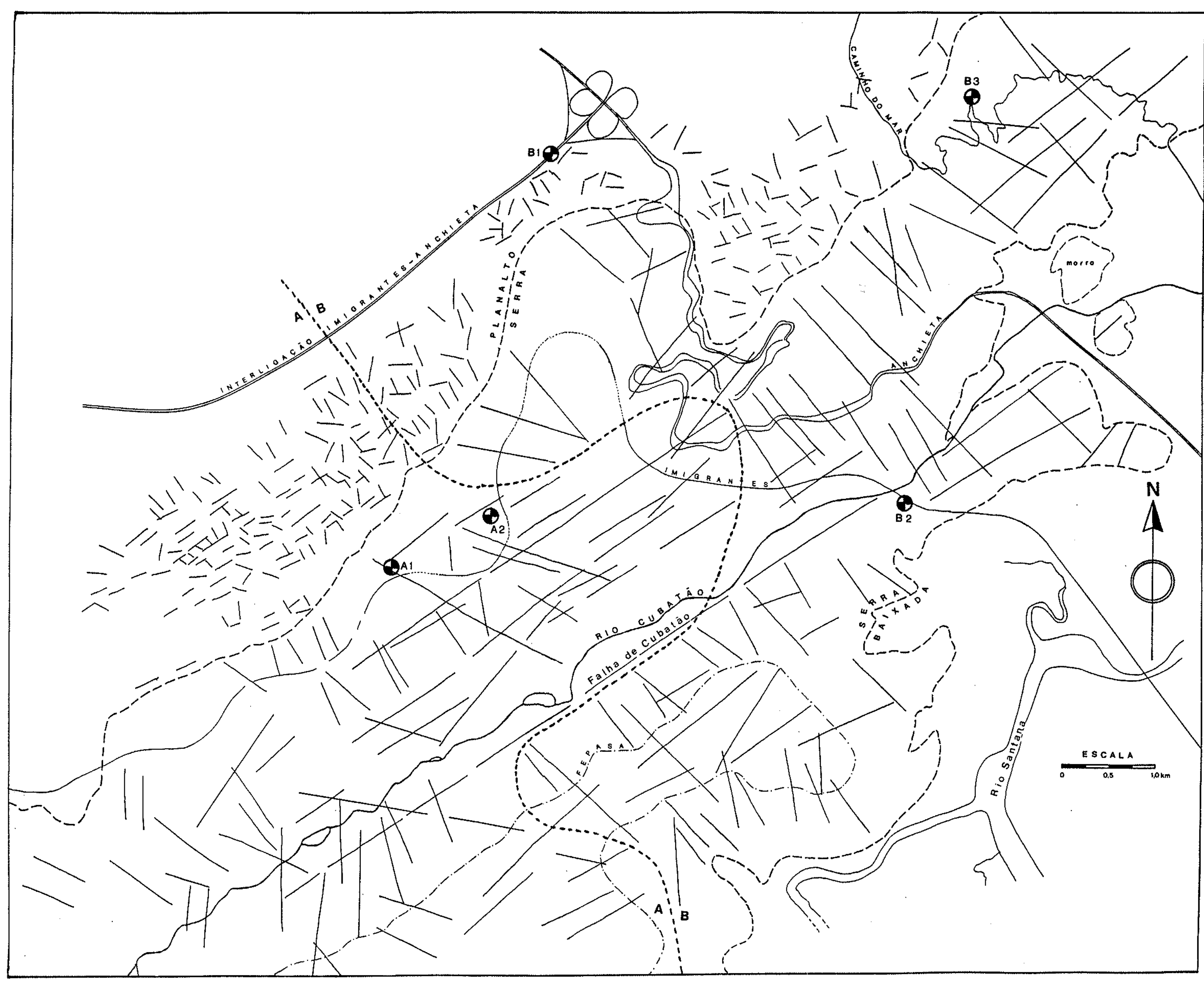

FOTOLINEAMENTOS

CONVENÇÓES
Rodovias
Aine Limite de áreas
Bineamento

Base: Fotos afreas escaia
1:25000 - BASE/1994 Fotos aéreas sescale
1:2000 - USAF/1965 


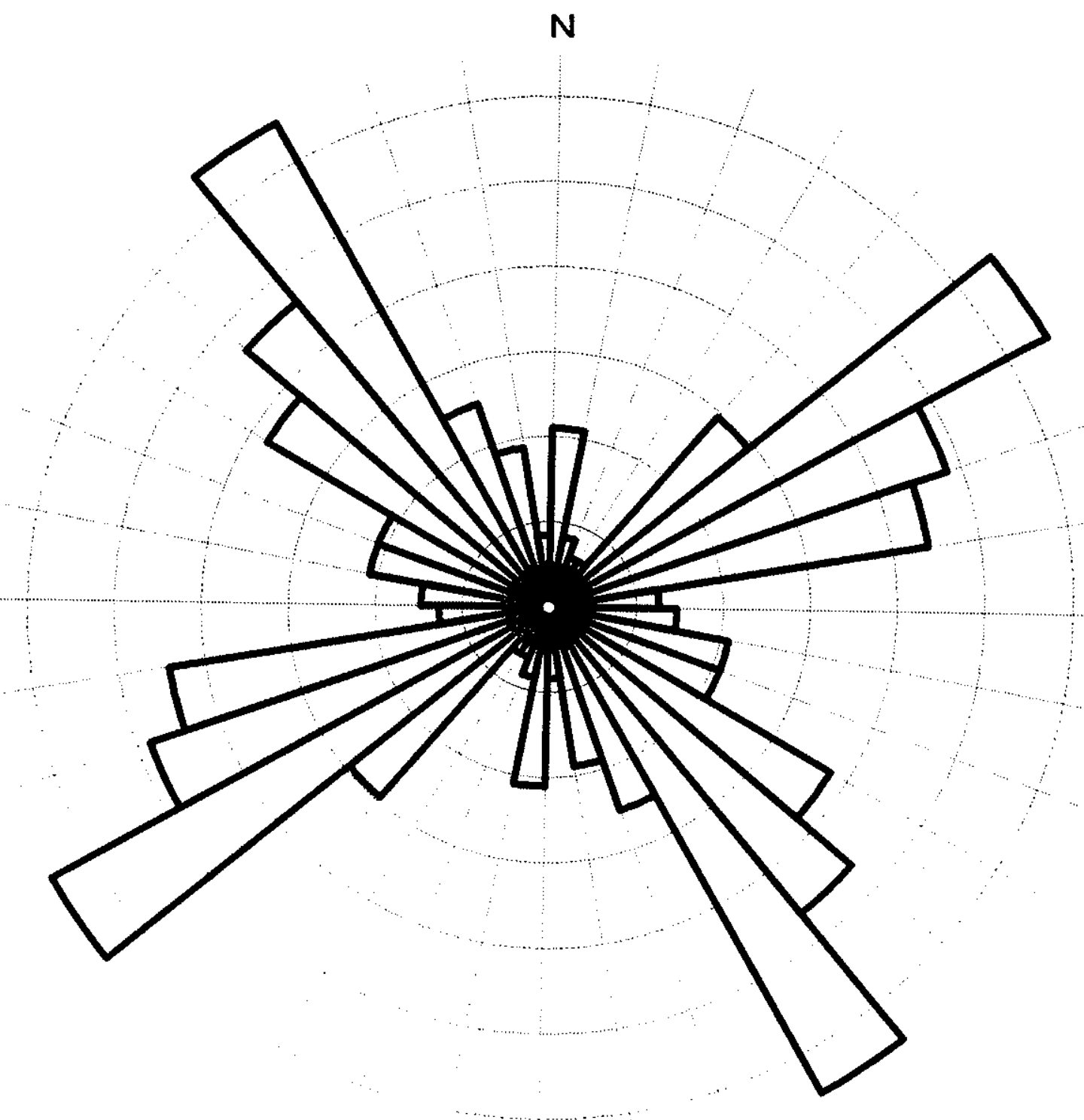

\begin{tabular}{|c|c|}
\hline $\begin{array}{c}\alpha^{0} \\
\text { (azimute) }\end{array}$ & $\begin{array}{c}N^{0} \\
\text { (frequência) }\end{array}$ \\
\hline $01-10$ & 10 \\
\hline $11-20$ & 4 \\
\hline $21-30$ & 3 \\
\hline $31-40$ & 3 \\
\hline $41-50$ & 14 \\
\hline $51-60$ & 31 \\
\hline $61-70$ & 23 \\
\hline $71-80$ & 21 \\
\hline $81-90$ & 6 \\
\hline $91-100$ & 7 \\
\hline $101-110$ & 10 \\
\hline $111-120$ & 10 \\
\hline $121-130$ & 18 \\
\hline $131-140$ & 22 \\
\hline $141-150$ & 31 \\
\hline $151-160$ & 12 \\
\hline $161-170$ & 9 \\
\hline $171-180$ & 4 \\
\hline Total & 238 \\
\hline
\end{tabular}

Frequências de lineamentos Área do Planalto

Figura III.2.2.2. Diagrama de frequências em rosácea. Área do Planalto 


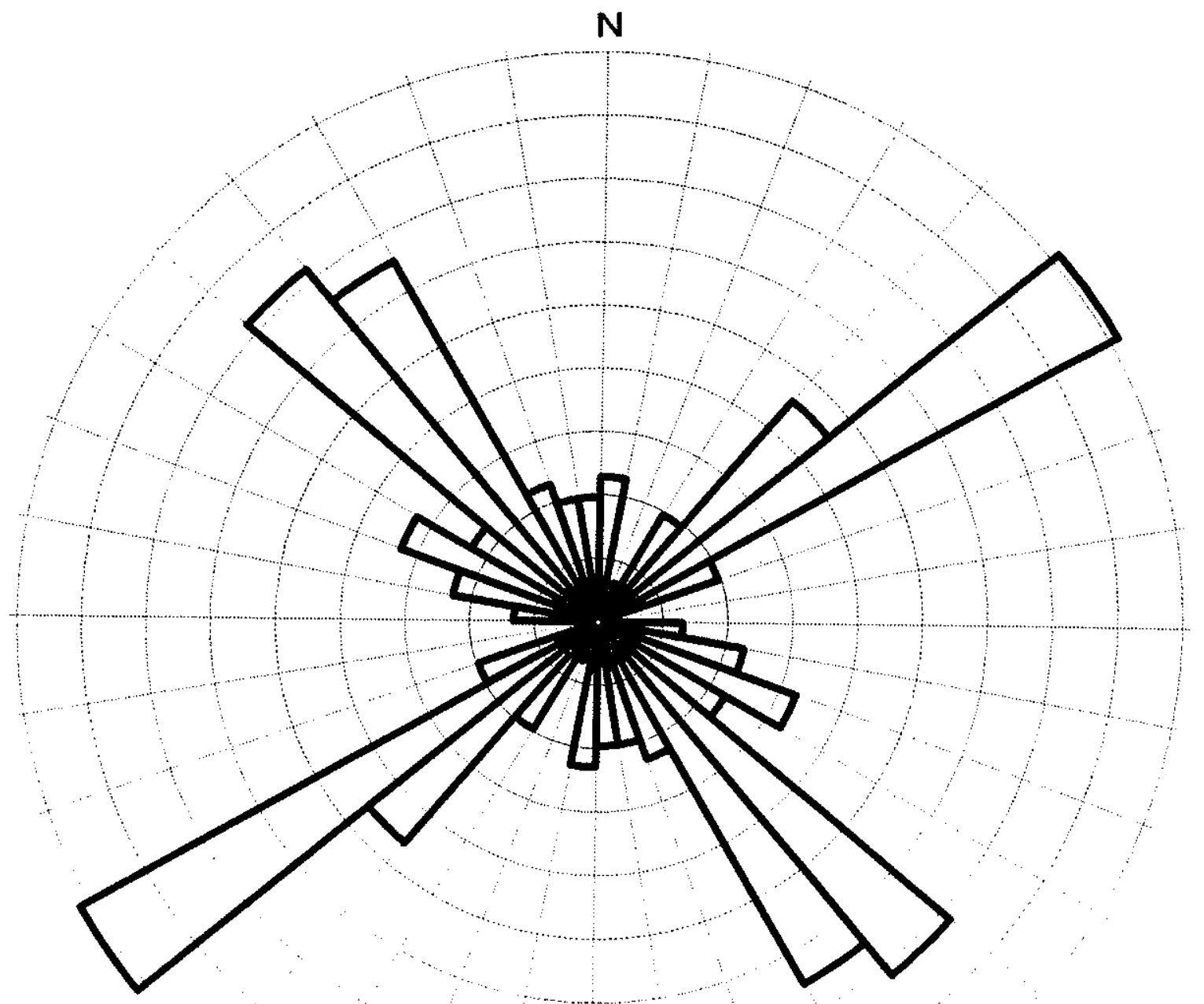

\begin{tabular}{|c|c|}
\hline $\begin{array}{c}\alpha^{0} \\
\text { (azimute) }\end{array}$ & $\begin{array}{c}\mathbf{N}^{\circ} \\
\text { (frequência) }\end{array}$ \\
\hline $01-10$ & 7 \\
\hline $11-20$ & 0 \\
\hline $21-30$ & 2 \\
\hline $31-40$ & 6 \\
\hline $41-50$ & 14 \\
\hline $51-60$ & 28 \\
\hline $61-70$ & 6 \\
\hline $71-80$ & 1 \\
\hline $81-90$ & 0 \\
\hline $91-100$ & 4 \\
\hline $101-110$ & 7 \\
\hline $111-120$ & 10 \\
\hline $121-130$ & 7 \\
\hline $131-140$ & 22 \\
\hline $141-150$ & 20 \\
\hline $151-160$ & 7 \\
\hline $161-170$ & 6 \\
\hline $171-180$ & 6 \\
\hline Total & 153 \\
\hline
\end{tabular}

Frequências de lineamentos

Área da Serra e Vale do Cubatão

Figura III.2.2.3. Diagrama de frequências em rosácea. Área da Serra e Vale do Cubatão 


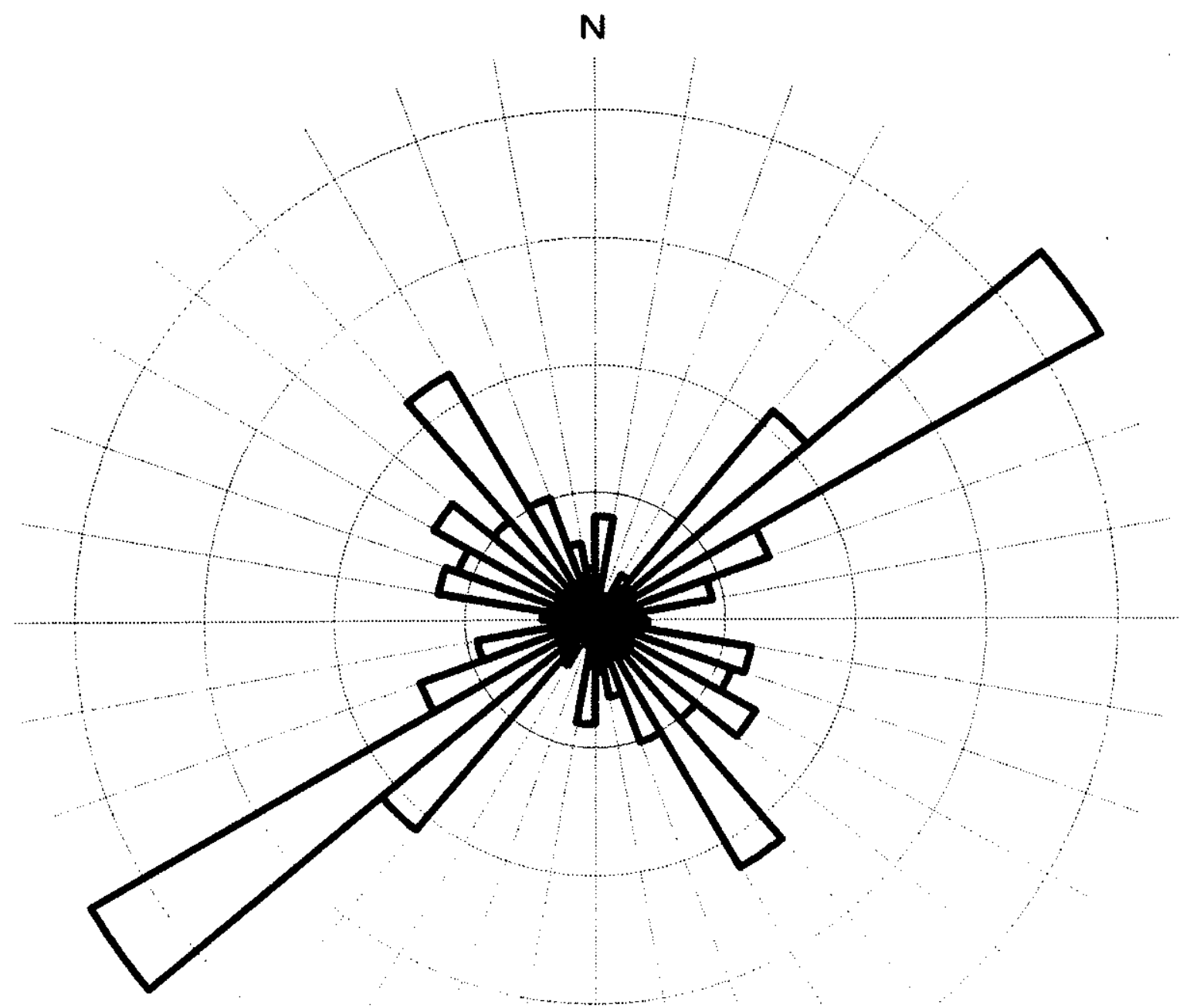

\begin{tabular}{|c|c|}
\hline $\begin{array}{c}\alpha^{0} \\
\text { (azimute) }\end{array}$ & $\begin{array}{c}N^{\circ} \\
\text { (frequência) }\end{array}$ \\
\hline $01-10$ & 8 \\
\hline $11-20$ & 0 \\
\hline $21-30$ & 2 \\
\hline $31-40$ & 4 \\
\hline $41-50$ & 21 \\
\hline $51-60$ & 44 \\
\hline $61-70$ & 14 \\
\hline $71-80$ & 9 \\
\hline $81-90$ & 2 \\
\hline $91-100$ & 4 \\
\hline $101-110$ & 12 \\
\hline $111-120$ & 11 \\
\hline $121-130$ & 14 \\
\hline $131-140$ & 10 \\
\hline $141-150$ & 22 \\
\hline $151-160$ & 10 \\
\hline $161-170$ & 6 \\
\hline $171-180$ & 4 \\
\hline Total & 197 \\
\hline
\end{tabular}

Frequências de lineamentos

Área A

Figura III.2.2.4. Diagrama de frequências em rosácea. Área A 


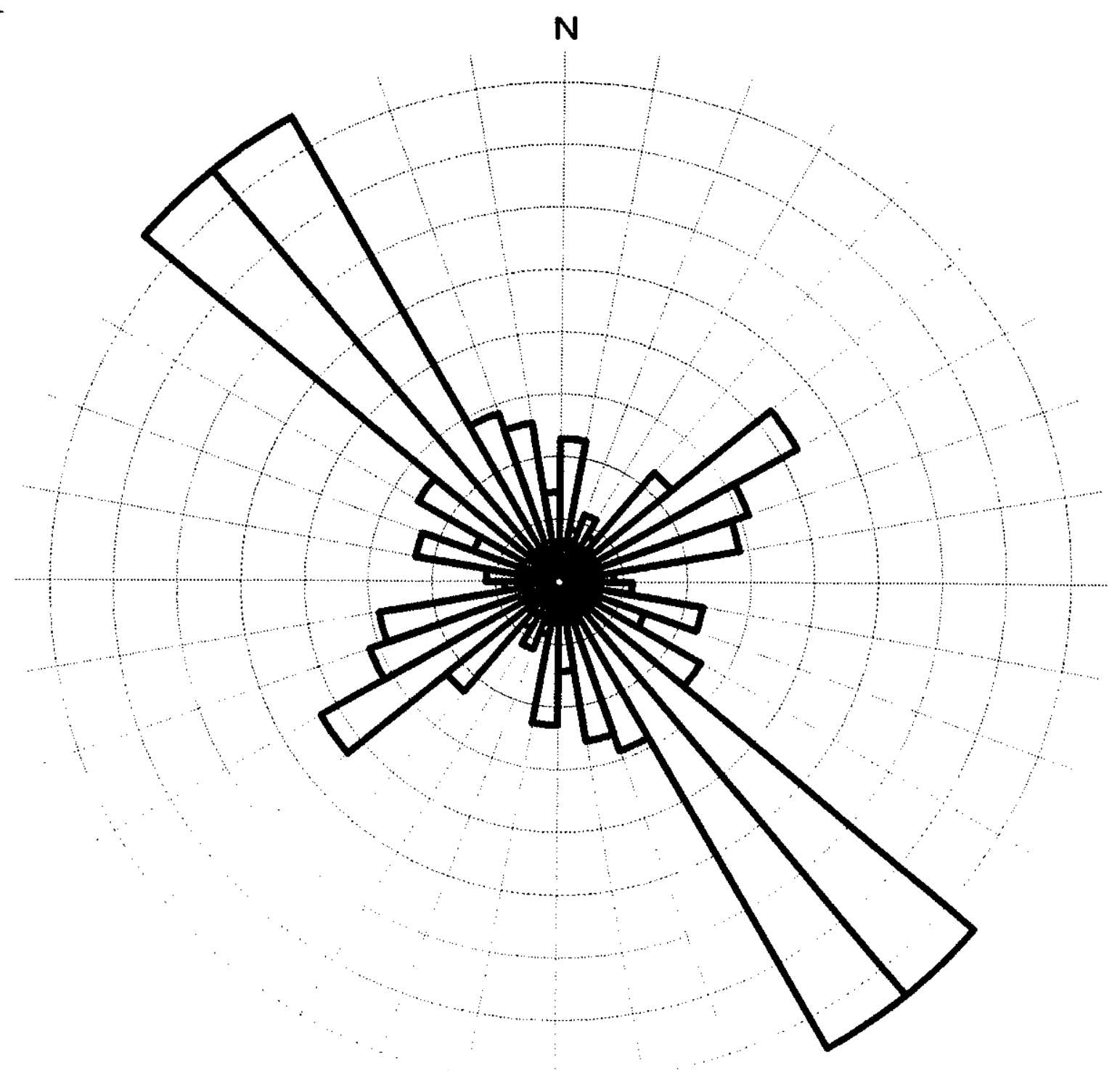

\begin{tabular}{|c|c|}
\hline $\begin{array}{c}\alpha^{0} \\
\text { (azimute) }\end{array}$ & $\begin{array}{c}N^{0} \\
\text { (frequência) }\end{array}$ \\
\hline $01-10$ & 8 \\
\hline $11-20$ & 3 \\
\hline $21-30$ & 4 \\
\hline $31-40$ & 3 \\
\hline $41-50$ & 8 \\
\hline $51-60$ & 15 \\
\hline $61-70$ & 11 \\
\hline $71-80$ & 10 \\
\hline $81-90$ & 3 \\
\hline $91-100$ & 4 \\
\hline $101-110$ & 8 \\
\hline $111-120$ & 5 \\
\hline $121-130$ & 9 \\
\hline $131-140$ & 30 \\
\hline $141-150$ & 30 \\
\hline $151-160$ & 10 \\
\hline $161-170$ & 9 \\
\hline $171-180$ & 5 \\
\hline Total & 175 \\
\hline
\end{tabular}

Frequências de lineamentos

Área B

Figura III.2.2.5. Diagrama de frequências em rosácea. Área B 
Uma análise dos diagramas de frequências apresentados, permite concluir:

Área do Planalto: apresenta duas direções principais, igualmente destacadas, segundo $\mathrm{N} 50^{\circ}-60^{\circ}$ e $\mathrm{N} 140^{\circ}-150^{\circ}$.

Área da Serra e Vale do Cubatão: apresenta uma direção principal N $50^{\circ}-60^{\circ}$ e uma direção secundária $\mathrm{N} 130^{\circ}-150^{\circ}$.

Essas duas áreas mostram padrões de lineamentos aparentemente bem diferentes quando observadas no mapa.

Entretanto, essa diferença está ligada principalmente aos comprimentos, pois quando analisamos as direções dos lineamentos através dos diagramas de rosáceas, observamos que tem distribuição semelhante para ambas as áreas, prevalecendo a direção N $50^{\circ}-60^{\circ}$.

Quanto à direção $\mathrm{N} 140^{\circ}-150^{\circ}$, que tambem é proeminente no Planalto, torna-se secundária, segundo $\mathrm{N} 130^{\circ}-150^{\circ}$, na Serra e Vale.

Área A (na parte SW): apresenta uma direção principal bem destacada em $\mathrm{N} 50^{\circ}-60^{\circ}$ e uma direção secundária em $\mathrm{N} 140^{\circ}-150^{\circ}$.

Área B (na parte NE): apresenta uma direção principal bem destacada em $\mathrm{N} 130^{\circ}-150^{\circ}$ e uma direção secundária em $\mathrm{N} 50^{\circ}-60^{\circ}$.

As áreas A e B, apresentam certa diferença visual, quando observadas no mapa, uma vez que na primeira os fotolineamentos são mais extensos segundo NE-SW e na segunda segundo NW-SE.

Quando analisados através dos diagramas de rosáceas, verificamos que basicamente as mesmas direções se destacam nos dois casos, entretanto essa diferença fica manifestada na inversão entre as direções principal e sucundária nas áreas $\mathrm{A}$ e B.

A direção $\mathrm{N} 50^{\circ}-60^{\circ}$ proeminente nas 4 áreas mencionadas, corresponde à direção da foliação de transposição ondulada, conforme citado em III.2.1., a qual se mostra intensificada próxima às zonas de falhas.

Essa mesma direção, corresponde tambem à direção das grandes falhas transcorrentes regionais, conforme descrito por EGYDIO DA SILVA et al (1982).

É $\circ$ caso da Falha de Cubatão, que na área da pesquisa apresenta tambem, localmente, características de acavalamento. 


\section{III.2.3. Estruturas Rúpteis - Juntas}

Foram realizados levantamentos de campo, considerando os planos de juntas de 5 locais representativos das áreas chamadas A e B. Nesses locais, a existência de afloramentos rochosos permitiu uma segura medição das atitudes estruturais dos planos.

Foi utilizada no levantamento de campo uma bússola tipo Clar, previamente declinada (declinação $19^{\circ} \mathrm{W}$ ), o que facilitou bastante o trabalho pois, como se sabe, com esse tipo de bússola basta uma única medida para cada plano, obtendose diretamente o ângulo de mergulho e o rumo do mergulho.

Os dados na notação Clar, foram posteriormente tratados diretamente em computador, através do "Programa Quickplot, versão 1990".

Os estereogramas obtidos com o uso do programa mostram os polos dos planos das juntas segundo uma distribuição gaussiana, com indicação de curvas de contorno (isolinhas), representando as porcentagem de pontos plotados, por unidade percentual de área do estereograma.

A distribuição dos nódulos de contagem utilizados pelo programa é baseada na rede de Kalsbeek modificada. Foi escolhida a opção "high density", com contagem automática, a qual considera 1261 nódulos para os círculos de contagem. As curvas de contorno traçadas, tem sempre a de $1 \%$ como a de valor mais baixo $e$ obviamente, a porcentagem máxima encontrada, como o valor mais alto, sendo os intervalos das isolinhas iguais em cada estereograma.

Os estereogramas tem como referência o diagrama de "Schmidt-Lambert", com projeção no hemisfério inferior.

Foram estudados 2 locais na Área A e 3 na Área B, cujas localizações estão indicadas na Figura III.2.2.1., já apresentada anteriormente.

Os locais estudados e as famílias de juntas encontradas são sumariamente descritos a seguir: 


\section{- Ponto A1}

Localizado junto à estrada de serviço da Rodovia dos Imigrantes, à montante do vale conhecido como VA-10 (viaduto ascendente $\mathrm{n}^{\circ} .10$ ). Foram levantados 92 planos de juntas que resultaram no estereograma da Figura III.2.3.1.

A Fotografia III.2.3.1., dá uma visão restrita do local do levantamento, junto à borda da estrada.

Familias principais (Isolinhas de 5\%):

Família $1 . \mathrm{N} 45^{\circ} / \partial=86^{\circ} \mathrm{NW}$

Família $2 . \mathrm{N} 68^{\circ} / \partial=28^{\circ} \mathrm{SE}$

Familia secundária (Isolinha de 4\%):

Família 3. $\mathrm{N} 146^{\circ} / \partial=87^{\circ} \mathrm{NE}$

Observações:

a.) A foliação média medida no local é $\mathrm{N} 50^{\circ} / \partial=85^{\circ} \mathrm{NW}$.

b.) Para a família 1 , foi considerado um valor interpolado no estereograma.

c.) A família 1, assim considerada, virtualmente coincide com a foliação. De qualquer forma, nesse e em outros estereogramas, fica clara a influência da foliação na formação das discontinuidades.

d.) Prevalecem no local as juntas verticalizadas $e$ de mergulhos muito fortes para todos os quadrantes, mas predominantemente para NW.

e.) A família 2, entretanto, se diferencia dessa tendência e tem mergulho mais baixo, para $\mathrm{SE}$.

\section{- Ponto A2}

Localizado junto à estrada de serviço da Rodovia dos Imigrantes, a montante do emboque lado Santos do TA-9 (túnel ascendente no.9).

Foram medidos 66 planos de juntas que resultaram no estereograma da Figura III.2.3.2.

A Fotografia III.2.3.2. é uma vista do afloramento, junto à borda da estrada.

Familia principal (Isolinha de 12\%):

Família $1 . \mathrm{N} 45^{\circ} / \partial=76^{\circ} \mathrm{NW}$ 
Familias secundárias (Isolinhas de $3 \%$ ):

Familia 2. $\mathrm{N} 20^{\circ} / \partial=36^{\circ} \mathrm{SE}$

Familia 3. $\mathrm{N} 125^{\circ} / \partial=84^{\circ} \mathrm{NE}$

Familia 4. $\mathrm{N} 135 \% \partial=50^{\circ} \mathrm{NE}$

Observações:

a.) A foliação média medida no local é $\mathrm{N} 75^{\circ} / \partial=72^{\circ} \mathrm{NW}$.

b.) A familia 1 se destaca nítidamente sobre as demais

c.) Para a família 3, foi considerado um valor interpolado no estereograma.

- Ponto B1.

Localizado na Rodovia de Interligação-Anchieta-Imigrantes, a $250 \mathrm{~m}$ da Alça da Via Anchieta. Foram levantados 81 planos de juntas, conforme apresentado na Figura III.2.3.3.

A Fotografia III.2.3.3. mostra parte do afloramento rochoso no trecho central entre as duas pistas da rodovia.

Família principal (Isolinha de 12\%):

Família $1 . \mathrm{N} 132^{\circ} / \partial=86^{\circ} \mathrm{NE}$

Famílias secundárias (Isolinhas de 6\%):

Familia 2. $\mathrm{N} 85^{\circ} / \partial=41^{\circ} \mathrm{SE}$

Família 3. $\mathrm{N} 155^{\circ} / \partial=57^{\circ} \mathrm{NE}$

Familia secundária (Isolinha de 3\%)

Família 4. $\mathrm{N} 16^{\circ} / \partial=50^{\circ} \mathrm{NW}$

Observações:

a.) A foliação média medida no local é $\mathrm{N} 20^{\circ} / \partial=50^{\circ} \mathrm{NW}$

b.) A família 1, se destaca sobre as demais

c.) A familia 4, praticamente coincide com a foliação.

\section{- $\underline{\text { Ponto B2 }}$}

Localizado em corte rochoso da Rodovia dos Imigrantes, no trecho entre o rio Cubatão e a Rodovia Pedro Taques. O local bastante favorável, permitiu o levantamento de 154 planos de juntas que resultaram no estereograma da Figura III.2.3.4. 
Na Fotografia III.2.3.4., temos uma vista parcial do corte em final de execução para a construção da pista descendente (Pista W).

Famílias principais (Isolinhas de 6\%):

Familia 1. N $50^{\circ} / \partial=75^{\circ} \mathrm{NW}$

Familia 2. $\mathrm{N} 115^{\circ} / \partial=82^{\circ} \mathrm{SW}$

Familias secundárias (Isolinhas de 4\%):

Família 3. $\mathrm{N} 22^{\circ} / \partial=36^{\circ} \mathrm{SE}$

Família $4 . \mathrm{N} 85^{\circ} / \partial=37^{\circ} \mathrm{SE}$

Observações:

a.) A foliação média medida no local é $\mathrm{N} 50^{\circ} / \partial=80^{\circ} \mathrm{NW}$

b.) A família 1. está claramente condicionada pela foliação da rocha

c.) Para a família 2, foi considerada uma posição interpolada, entre dois contornos máximos muito próximos no estereograma.

- Ponto B3

Localizado em talvegue cruzado pelo Caminho do Mar, na altura do $\mathrm{km}$ 47,4. Foram medidos no local 94 planos de juntas, sendo os dados plotados em estereograma, conforme consta da Figura III.2.3.5..

A Fotografia III.2.3.5. é uma vista parcial do afloramento, aparecendo ainda a galeria sob a rodovia.

Família principal (Isolinha de 10\%):

Familia 1. N $60^{\circ} / \partial=82^{\circ} \mathrm{NW}$

Famílias secundárias (Isolinhas de 6\%):

Família 2. $\mathrm{N} 124^{\circ} / \partial=80^{\circ} \mathrm{NE}$

Familia 3. N $170^{\circ} / \partial=28^{\circ} \mathrm{NE}$

Observações:

a.) A foliação média medida no local é $\mathrm{N} 55^{\circ} / \partial=80^{\circ} \mathrm{NW}$

b.) A família 1 se destaca bastante sobre as demais e está condicionada pela foliação.

c.) A família 3, corresponde ao plano rochoso visivel na foto. 


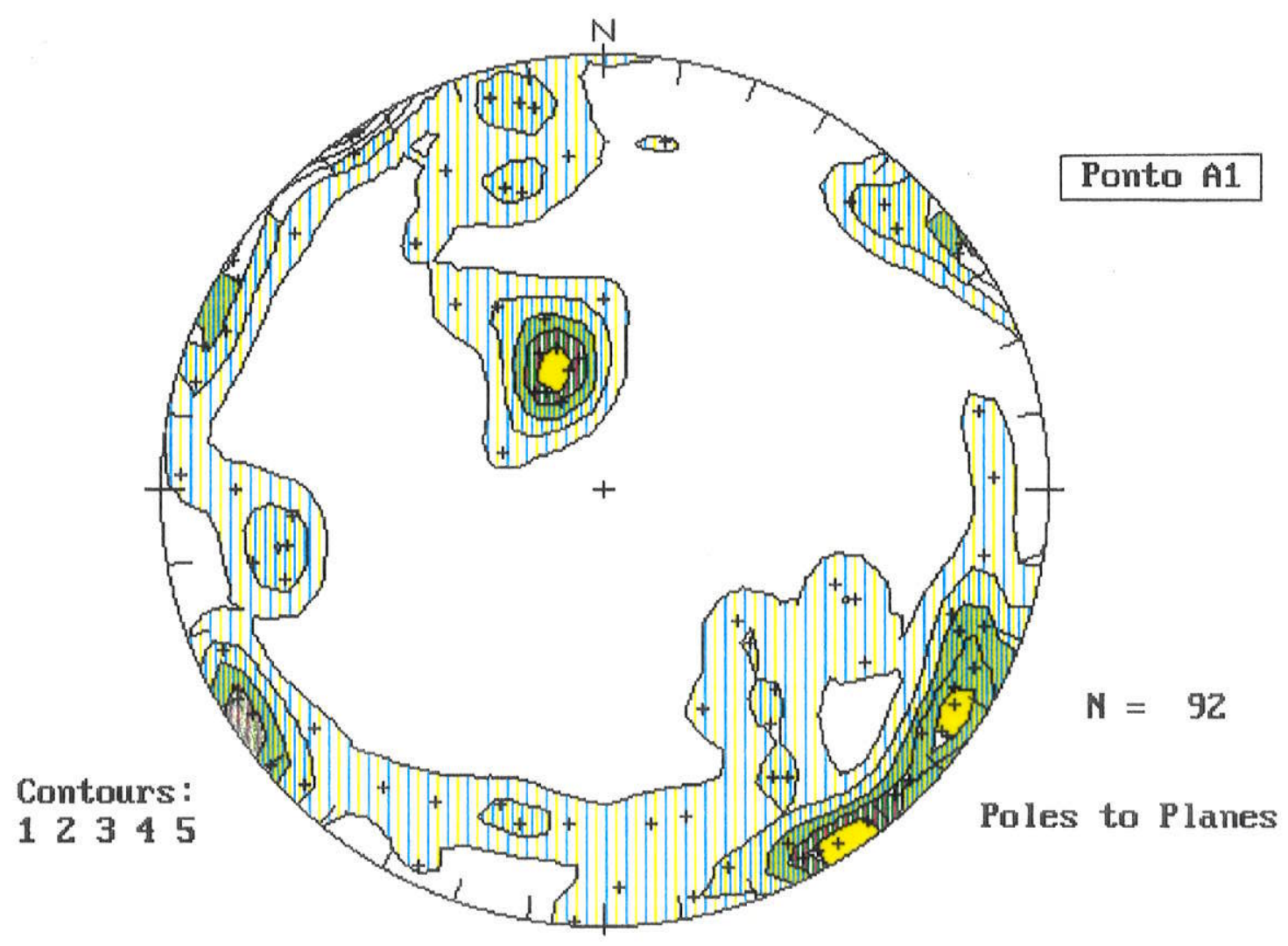

Figura III.2.3.1. Ponto A1. Estereograma de 92 polos de juntas

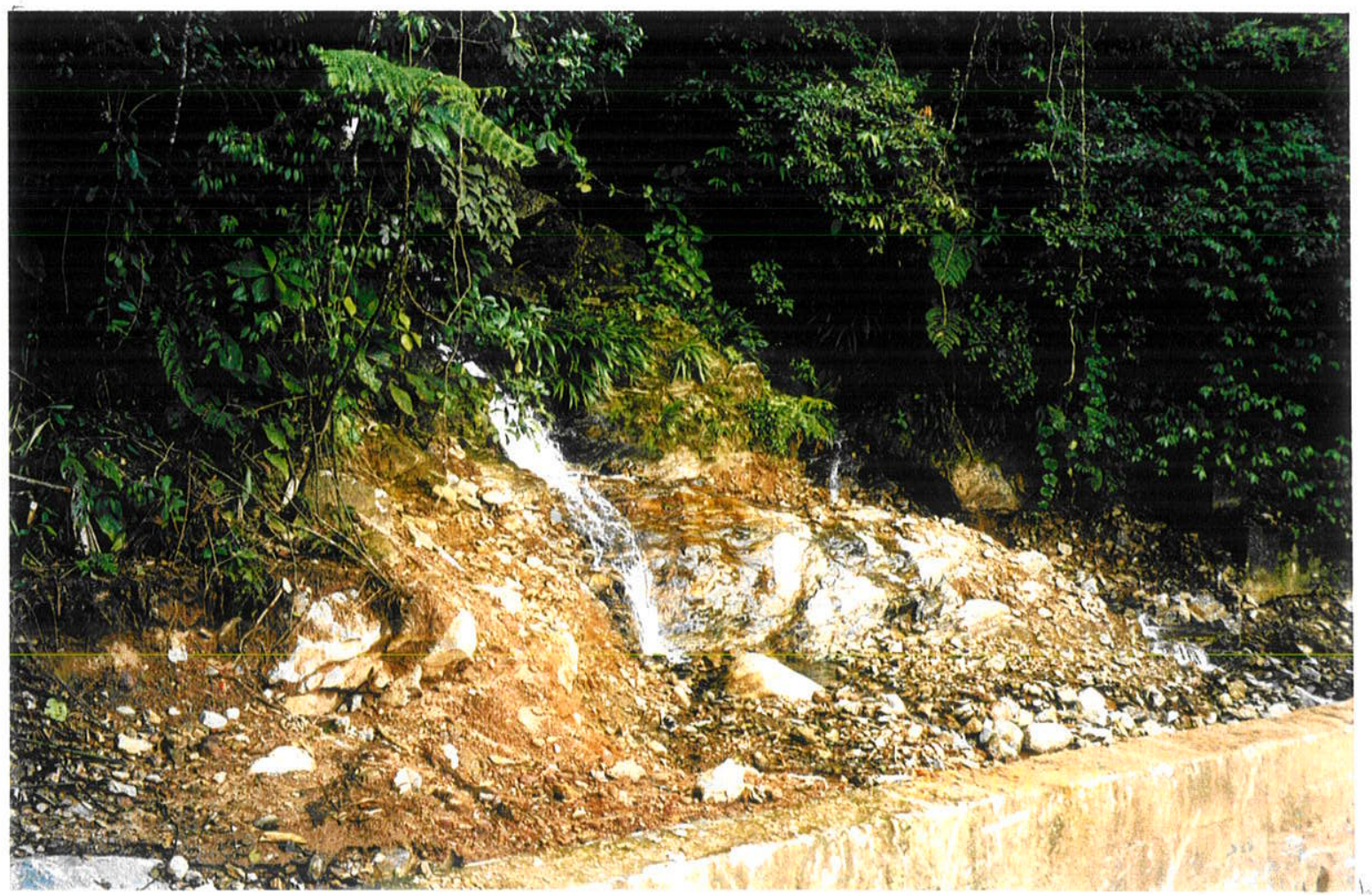

Fotografia III.2.3.1. Ponto A1. Visão restrita do local 


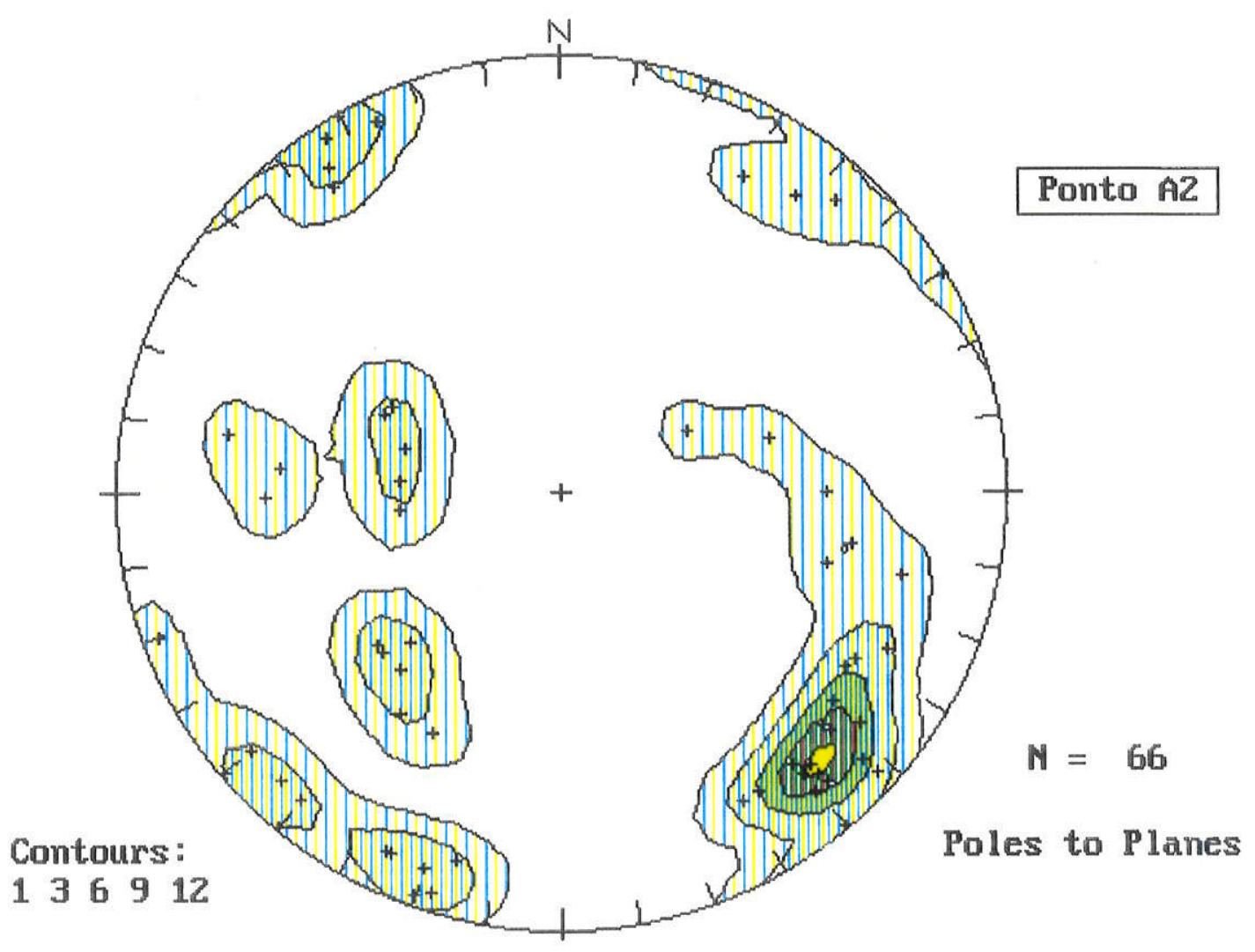

Figura III.2.3.2. Ponto A2. Estereograma de 66 polos de juntas

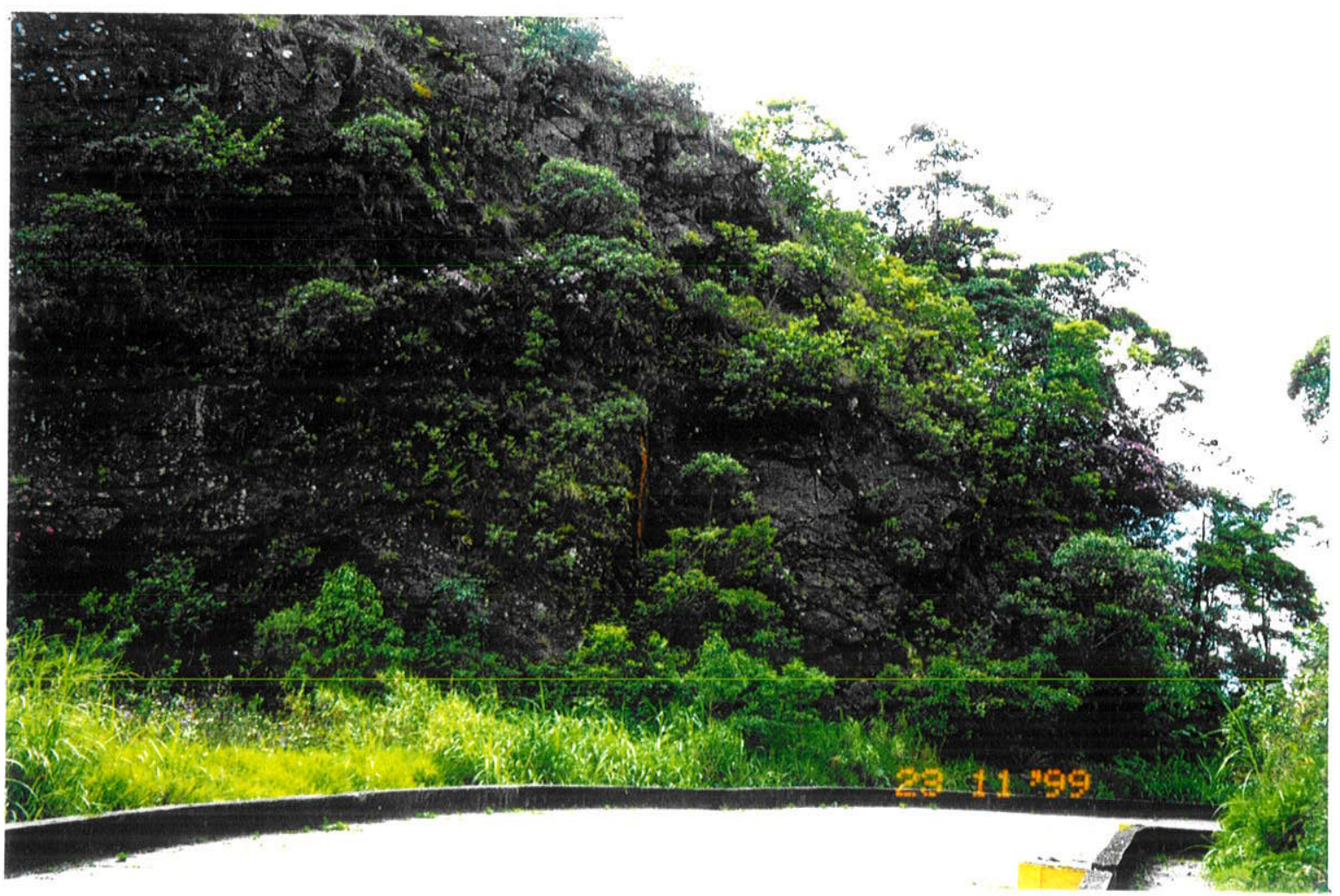

Fotografia III.2.3.2. Ponto A2. Visão do afloramento 


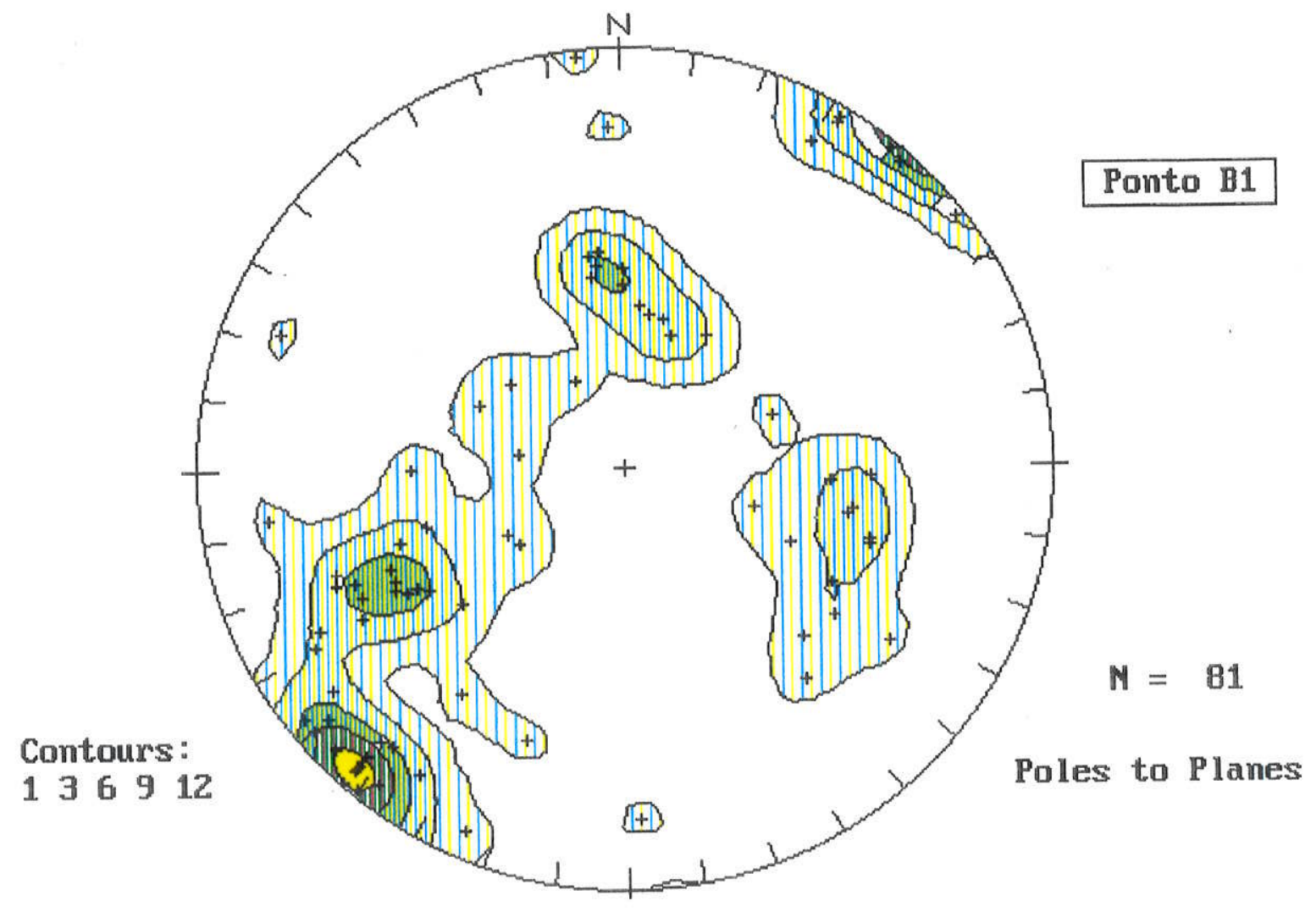

Figura III.2.3.3. Ponto B1. Estereograma de 81 polos de juntas

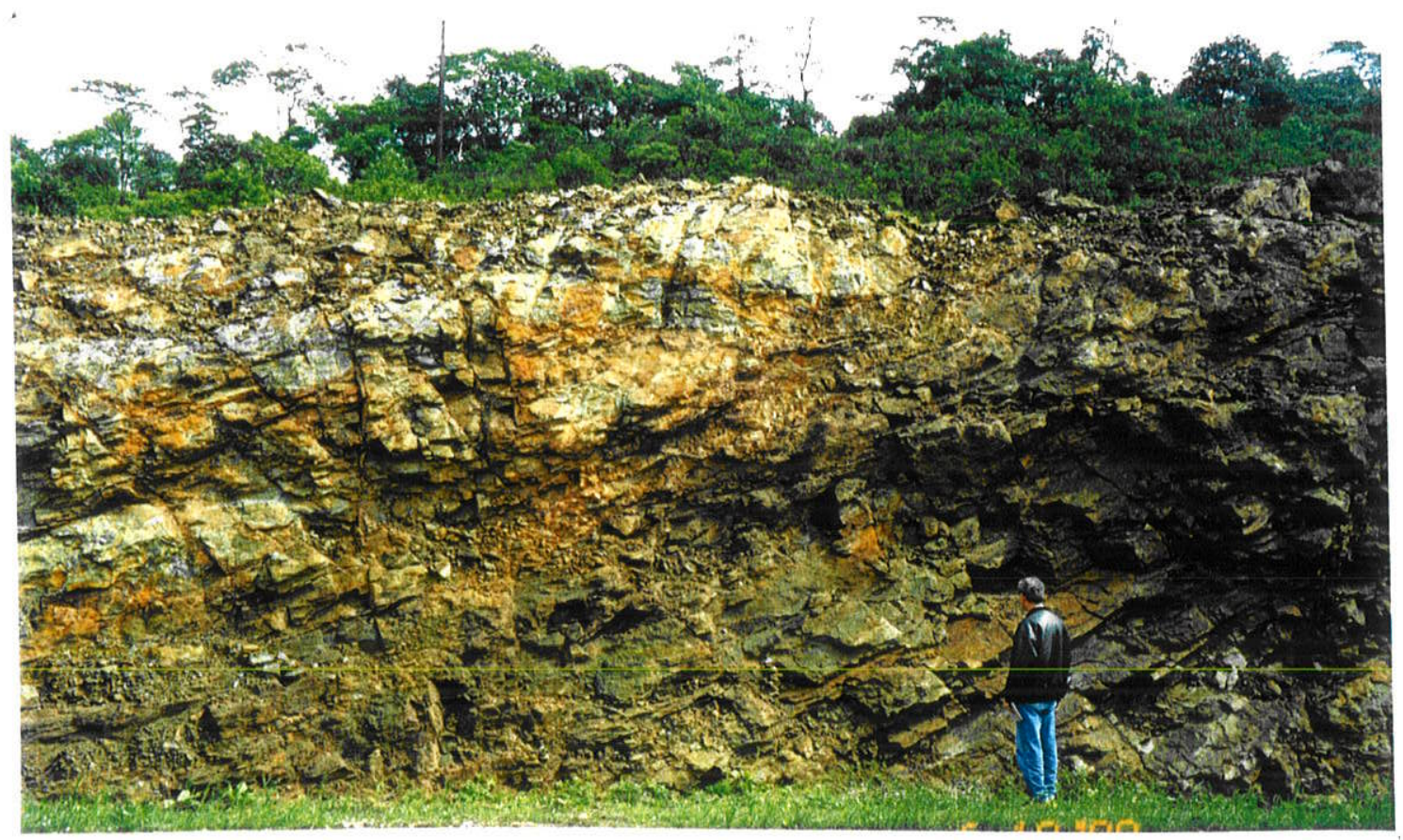

Fotografia III.2.3.3. Ponto B1. Vista parcial do local 


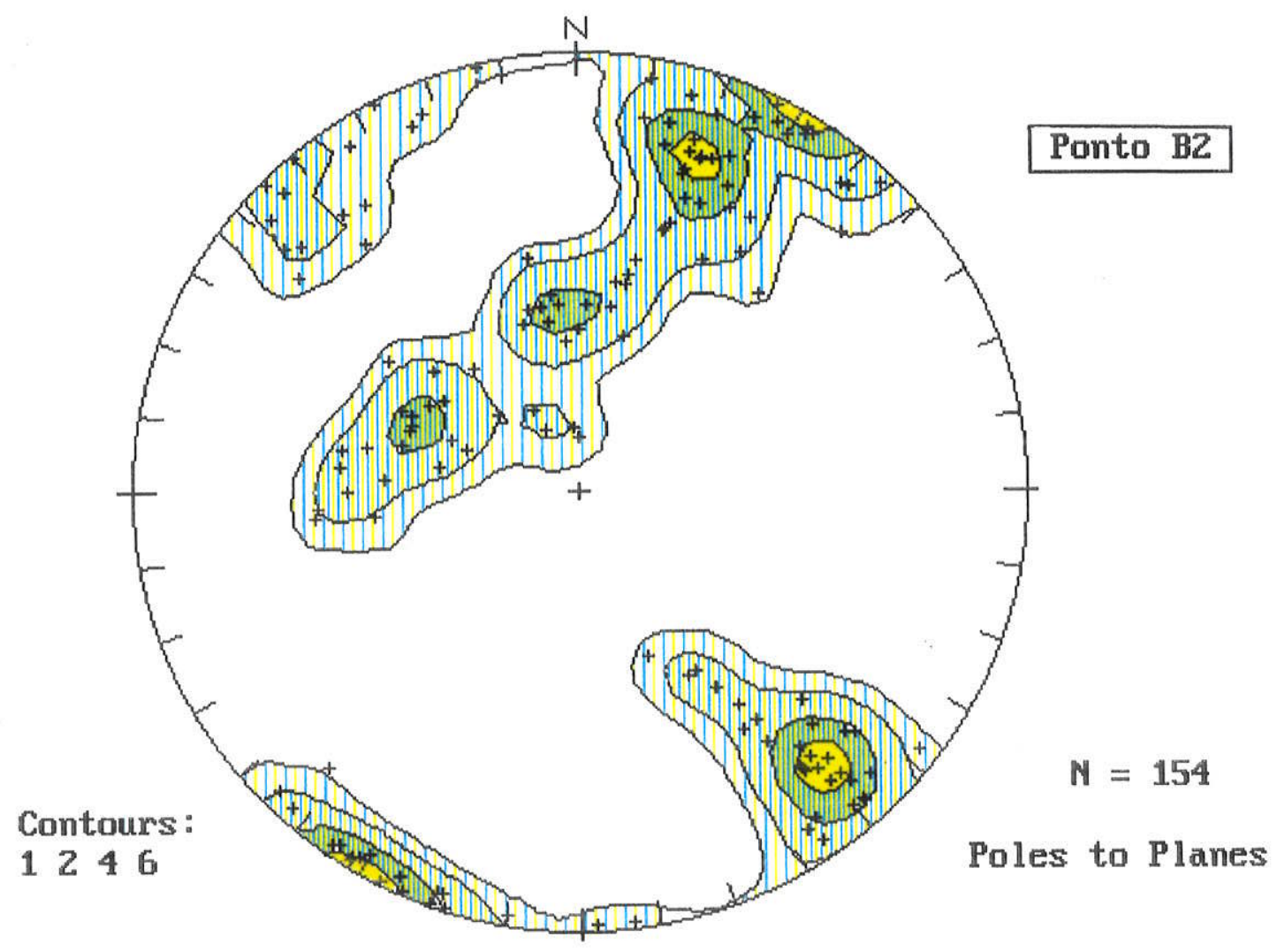

Figura III.2.3.4. Ponto B2. Estereograma de 154 polos de juntas

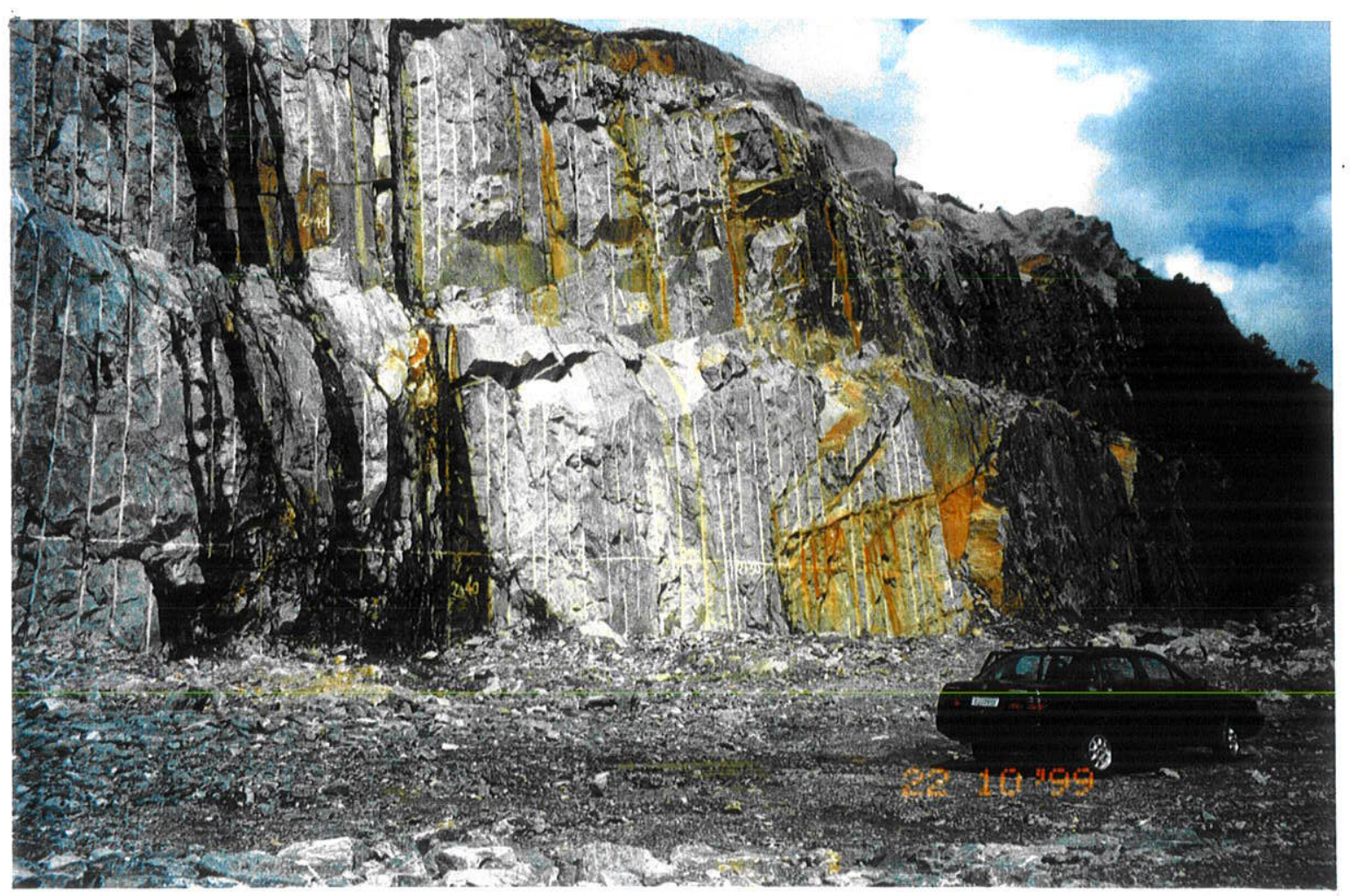

Fotografia III.2.3.4. Ponto B2. Vista do corte 


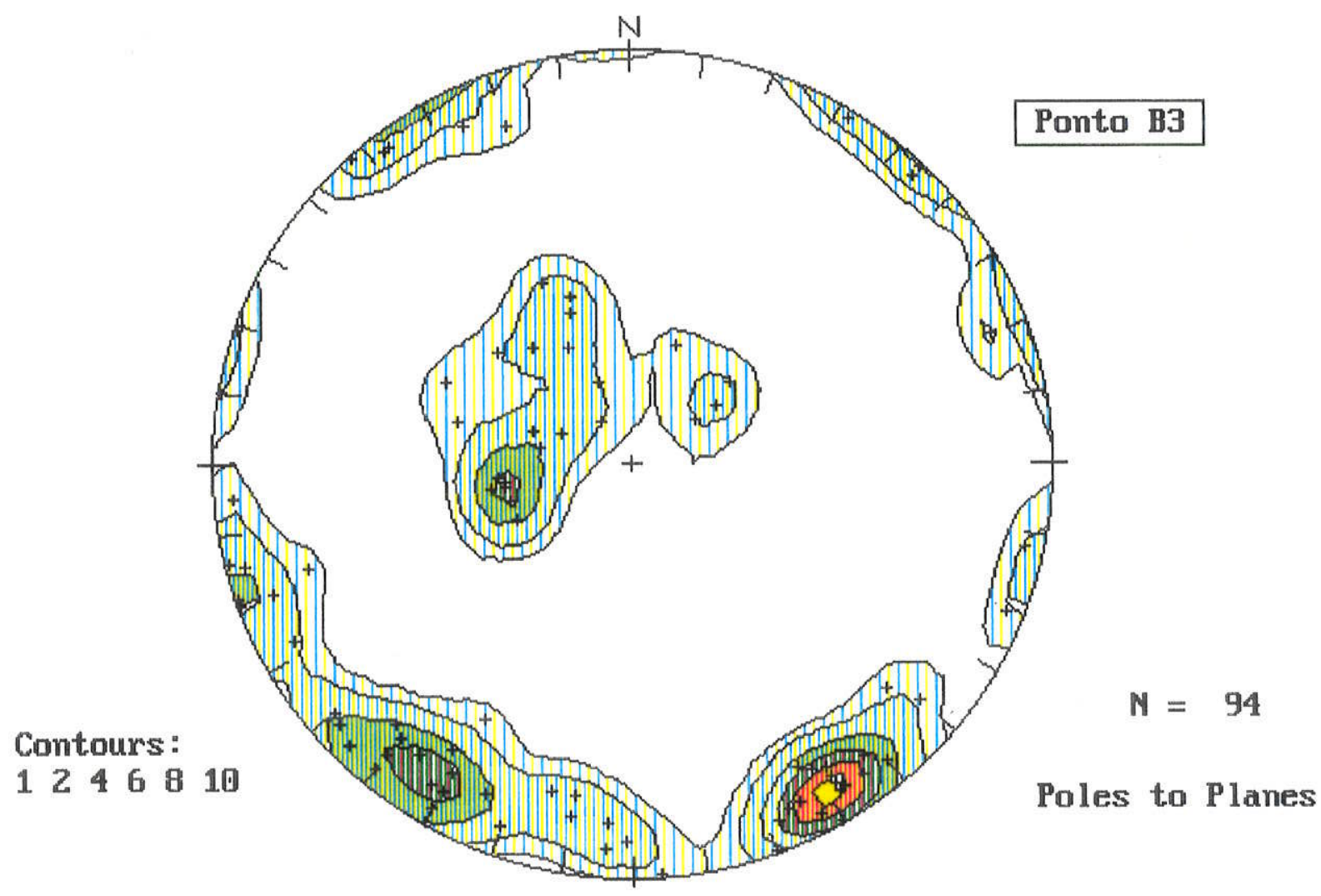

Figura III.2.3.5. Ponto B3. Estereograma de 94 polos de juntas

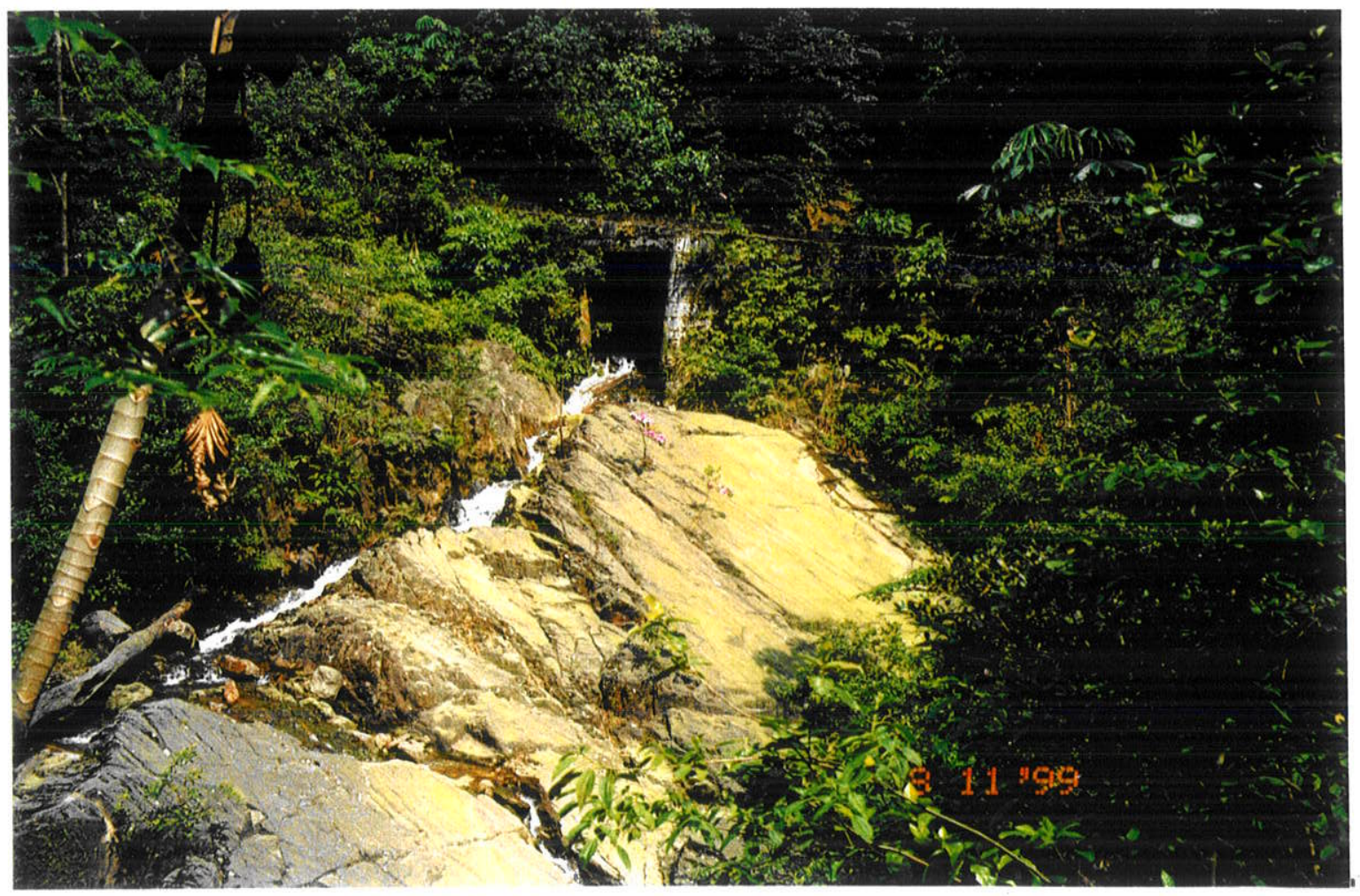

Fotografia III.2.3.5. Ponto B3. Vista parcial do afloramento 
As Figuras III.2.4.1. a III.2.4.5., apresentadas a seguir, permitem uma melhor visualização conjunta das principais estruturas rúpteis preponderantes em cada um dos 5 locais levantados.

A Tabela III.2.4.1., por sua vez, facilita a comparação dos valores numéricos das atitudes das estruturas lançadas nos estereogramas.

A observação desses gráficos permite, entre outras, as seguintes conclusões:

- Nos locais estudados existe sempre uma coincidência, ou grande aproximação, entre a foliaçào e um dos planos principais de juntas (plano secundário em B1), sendo os seus mergulhos para NW, geralmente superiores a $72^{\circ}\left(50^{\circ} \mathrm{em} \mathrm{B1}\right)$.

As direções desses planos de juntas e foliação são, exceto em B1, muito próximo às direções dos fotolineamentos (do principal na área $\mathrm{A} e$ do secundário na área $\mathrm{B}$ ), isto é $\mathrm{N} 55^{\circ}$.

É visível o condicionamento imposto pelas grandes estruturas regionais, como o Falhamento de Cubatão, de direção geral $N 55^{\circ}$ a $N 60^{\circ}$.

- Nos locais estudados, um dos planos secundários de juntas (principal no caso de B1), mergulha para $\mathrm{NE}$ e tem direção aproximada do fotolineamento - secundário na área $A$ e principal na área $B$ - isto é: $\mathrm{N} 140^{\circ}$ a $\mathrm{N} 145^{\circ}$.

- Em 4 dos locais levantados, um plano principal de junta, um plano secundário e a foliação, se interceptam segundo uma linha que mergulha para N-NW em A1, A2, B1 e, para NE em B3.

- As direções dos fotolineamentos nas áreas A e B, são praticamente ortogonais. 


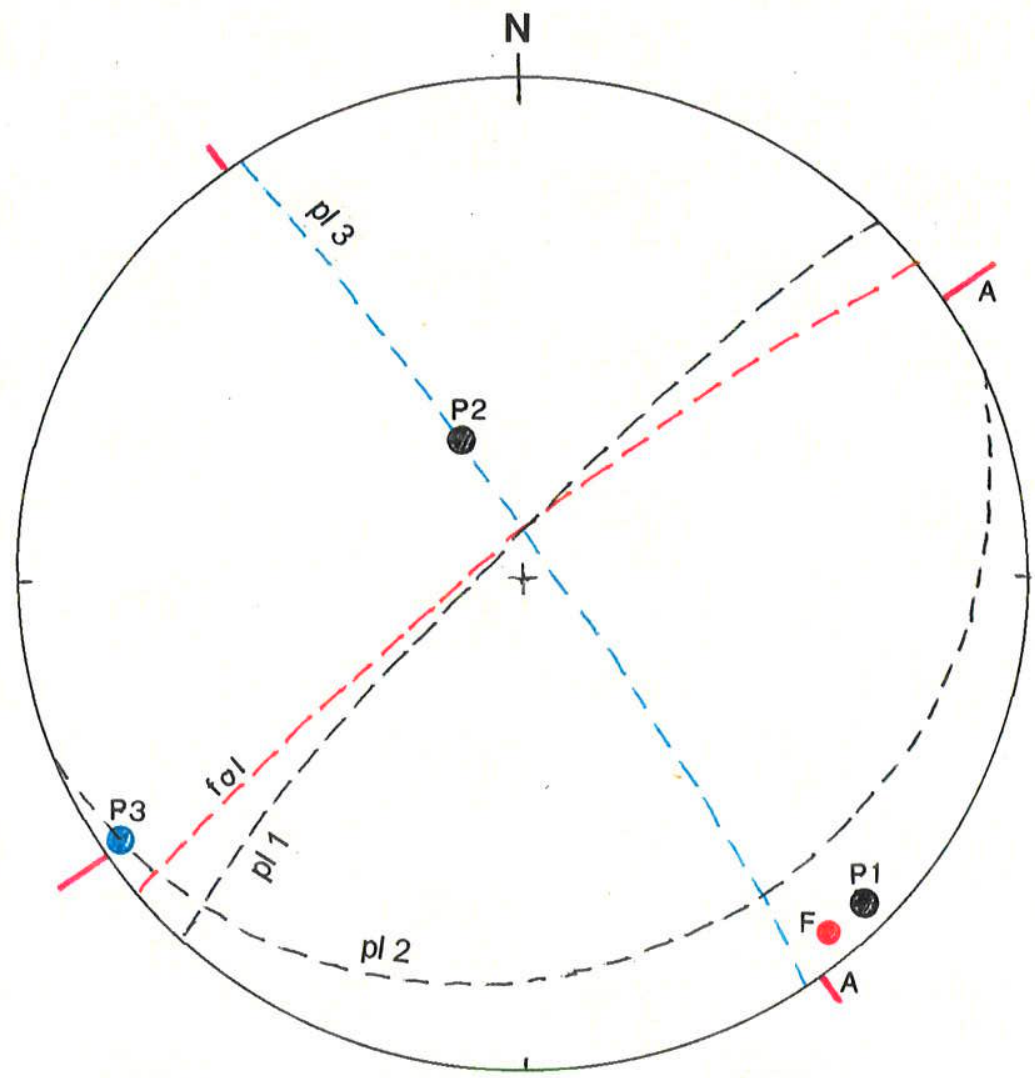

Figura III.2.4.1. Ponto A1. Estereograma das estruturas rúpteis predominantes

\section{Legenda dos Estereogramas}

P1

- Polo do plano de junta da família principal

pl 1.

Projeção ciclográfica do plano de junta da família principal

P3

- Polo do plano de junta de família secundária

pl 3 -

Projeção ciclográfica do plano de junta de familia secundária

$\mathrm{F}$

- Polo do plano médio da foliação

fol

fol -

Projeção ciclográfica do plano médio da foliação

A

Direção média do fotolineamento principal (área A)

$\underline{A}$

Direção média do fotolineamento secundário (área A) 


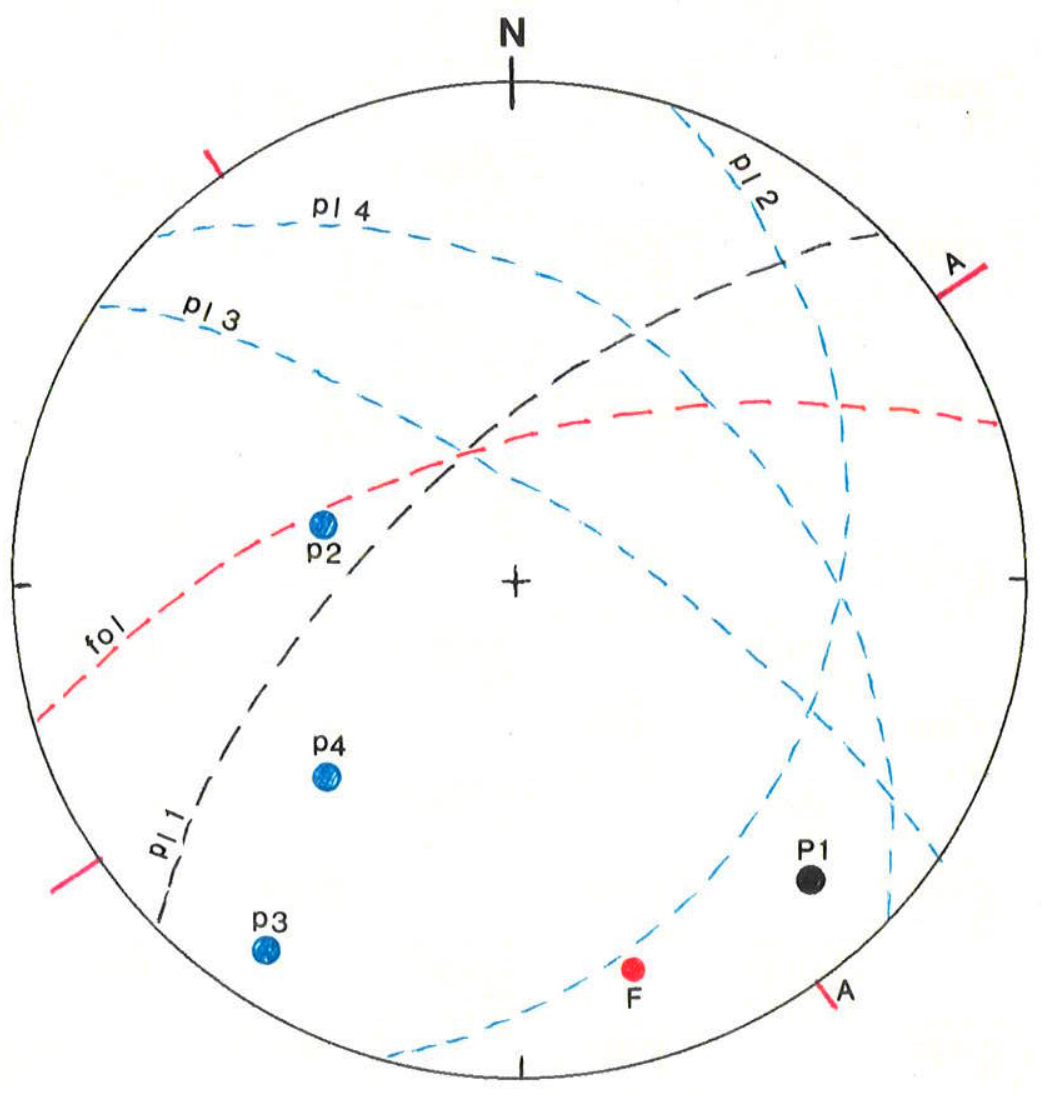

A 2

Figura III.2.4.2. Ponto A2. Estereograma das estruturas rúpteis predominantes

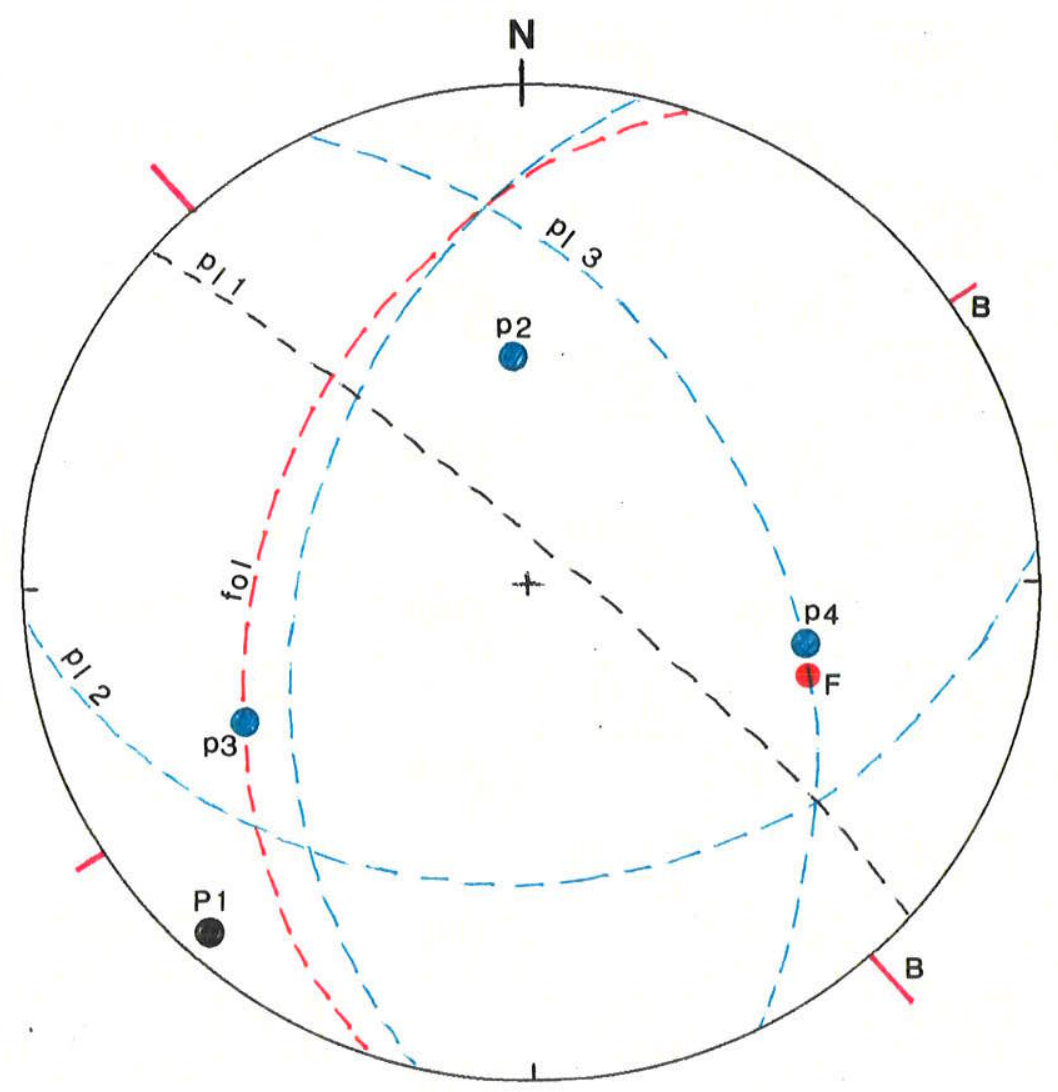

B 1

Figura III.2.4.3. Ponto B1. Estereograma das estruturas rúpteis predominantes 


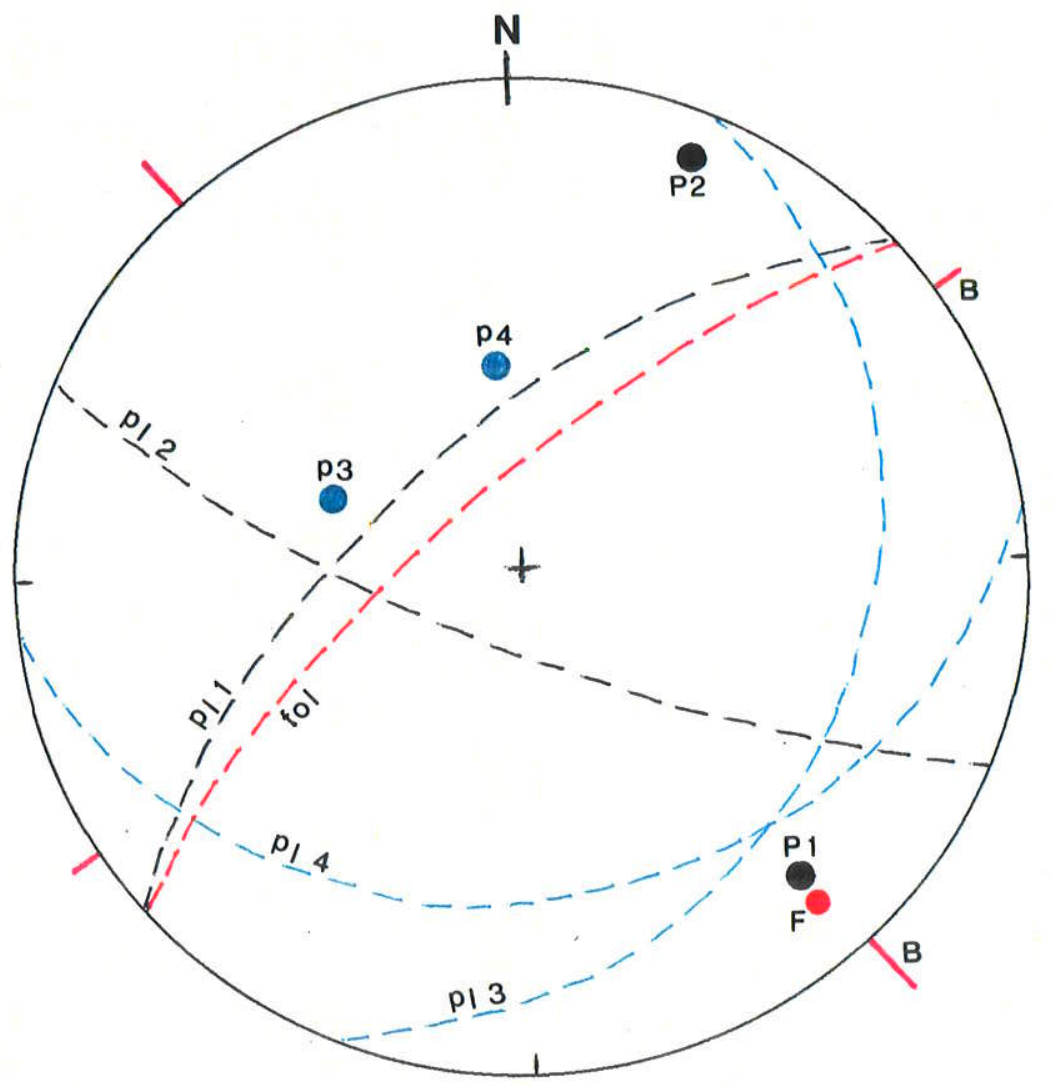

B 2

Figura III.2.4.4. Ponto B2. Estereograma das estruturas rúpteis predominantes

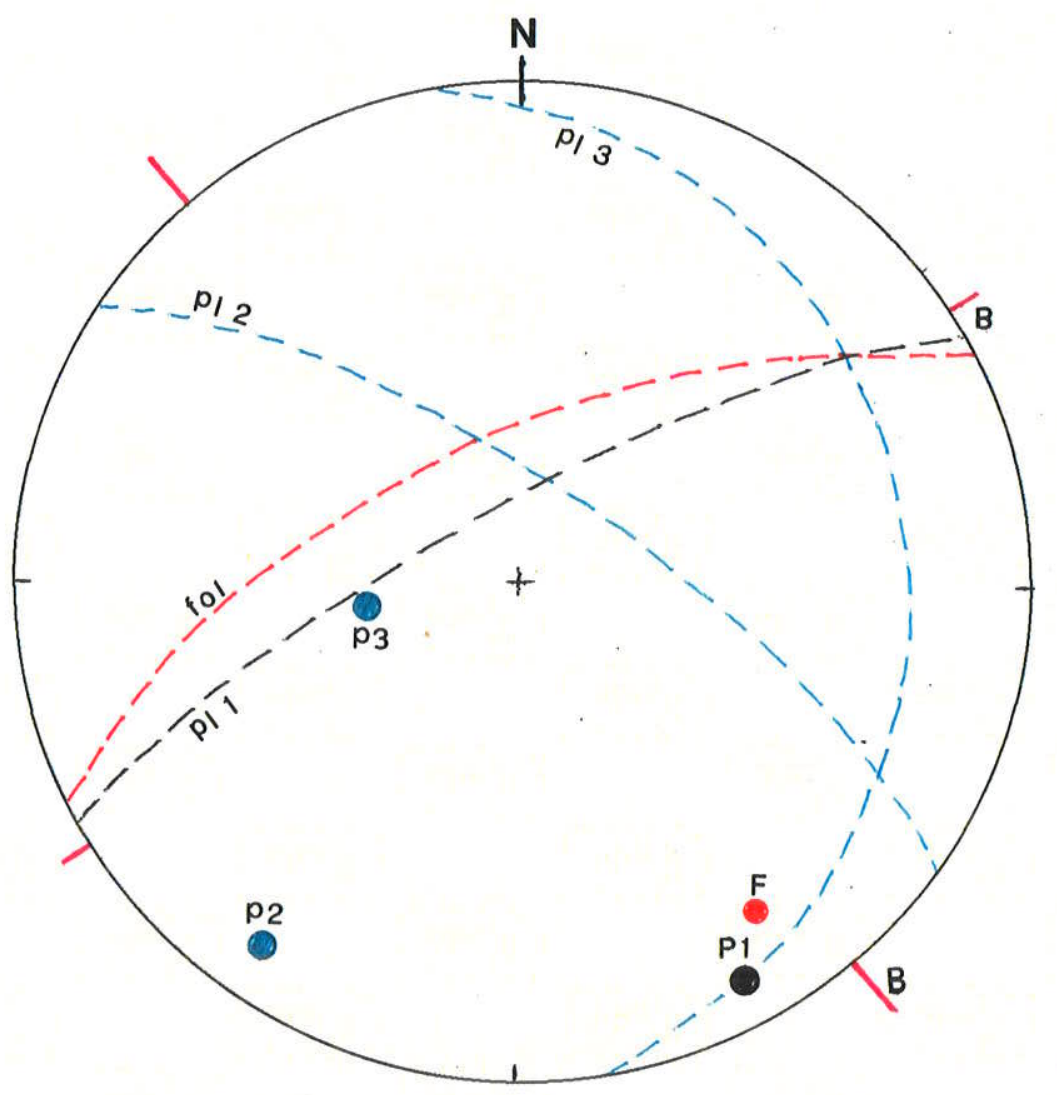

B 3

Figura III.2.4.5. Ponto B3. Estereograma das estruturas rúpteis predominantes 
Tabela III.2.4.1. Quadro comparativo das estruturas rúpteis preponderantes (direção/mergulho)

\begin{tabular}{|c|c|c|c|c|c|c|}
\hline LOCAL & $\begin{array}{c}\text { JUNTAS } \\
\text { PRINCIPAIS }\end{array}$ & $\begin{array}{c}\text { JUNTAS } \\
\text { SECUNDÁRIAS }\end{array}$ & $\begin{array}{c}\text { FOLIAÇÃO } \\
\text { MÉDIA }\end{array}$ & $\begin{array}{c}\text { FOTOLINEAM. } \\
\text { PRINCIPAL }\end{array}$ & $\begin{array}{l}\text { FOTOLINEAM. } \\
\text { SECUNDÁRIO }\end{array}$ & OBSERVAÇÃO \\
\hline \multirow[t]{2}{*}{ Ponto A1 } & ${ }^{*} \mathrm{~N} 45^{\circ} / 86^{\circ} \mathrm{NW}$ & $\mathrm{N} 146^{\circ} / 87^{\circ} \mathrm{NE}$ & $\mathrm{N} 50^{\circ} / 85^{\circ} \mathrm{NW}$ & $\mathrm{N} 55^{\circ}$ & $\mathrm{N} 145^{\circ}$ & $\begin{array}{l}\text { * Valor interpol. } \\
\text { no estereograma }\end{array}$ \\
\hline & $\mathrm{N} 68^{\circ} / 28^{\circ} \mathrm{SE}$ & & & & & \\
\hline \multirow{2}{*}{ Ponto A2 } & $N 45^{\circ} 76^{\circ} \mathrm{NW}$ & $\mathrm{N} 20^{\circ} / 36^{\circ} \mathrm{SE}$ & $\mathrm{N} 75^{\circ} / 72^{\circ} \mathrm{NW}$ & $\mathrm{N} 55^{\circ}$ & $\mathrm{N} 145^{\circ}$ & \\
\hline & & ${ }^{*} \mathrm{~N} 125^{\circ} / 84^{\circ} \mathrm{NE}$ & & & & $\begin{array}{l}\text { * Valor interpol. } \\
\text { no estereograma }\end{array}$ \\
\hline \multirow[t]{3}{*}{ Ponto B1 } & N132/86 NE & $\mathrm{N} 85^{\circ} / 41^{\circ} \mathrm{SE}$ & $\mathrm{N} 20^{\circ} / 50^{\circ} \mathrm{NW}$ & $\mathrm{N} 140^{\circ}$ & $N 55^{\circ}$ & \\
\hline & & $\mathrm{N} 155^{\circ} / 57^{\circ} \mathrm{NE}$ & & & & \\
\hline & & ${ }^{*} \mathrm{~N} 16^{\circ} / 50^{\circ} \mathrm{NW}$ & & & & $\begin{array}{c}{ }^{*} \text { Isolinha de } \\
\text { apenas } 3 \% \text { pontos }\end{array}$ \\
\hline \multirow{2}{*}{ Ponto B2 } & $\mathrm{N} 50^{\circ} / 75^{\circ} \mathrm{NW}$ & $\mathrm{N} 22^{\circ} / 36^{\circ} \mathrm{SE}$ & $\mathrm{N} 50^{\circ} / 80^{\circ} \mathrm{NW}$ & $\mathrm{N} 140^{\circ}$ & $\mathrm{N} 55^{\circ}$ & \\
\hline & ${ }^{*} \mathrm{~N} 115^{\circ} / 82^{\circ} \mathrm{SW}$ & $\mathrm{N} 85^{\circ} / 37^{\circ} \mathrm{SE}$ & & & & $\begin{array}{c}\text { * Valor interpol. } \\
\text { no estereograma }\end{array}$ \\
\hline \multirow[t]{2}{*}{ Ponto B3 } & $\mathrm{N} 60^{\circ} / 82^{\circ} \mathrm{NW}$ & $\mathrm{N} 124^{\circ} / 80^{\circ} \mathrm{NE}$ & $\mathrm{N} 55^{\circ} / 80^{\circ} \mathrm{NW}$ & $\mathrm{N} 140^{\circ}$ & $\mathrm{N} 55^{\circ}$ & \\
\hline & & $\mathrm{N} 170^{\circ} / 28^{\circ} \mathrm{NE}$ & & & & \\
\hline
\end{tabular}




\section{CAPítulo IV}

\section{GEOMORFOLOGIA DA ÁREA}

\section{IV.1. CONSIDERAÇÕES GERAIS}

Alguns autores procuraram explicar a formação e evolução geomorfológica da Serra de Cubatão, baseados em suas experiências e observações de campo e tambem em teorias e similitudes com outras áreas.

DE MARTONNE (1933), geógrafo francês que aqui esteve, comparou a Serra do Cubatão com um fenômeno ocorrido no sul do Maciço Central Francês - "O Espinouse". Admitiu na ocasião, que a Serra de Cubatão seria resultante do intenso fraturamento do seu fronte em estreitos blocos, os quais teriam sofrido abatimento em direção à Baixada Santista, abrindo consequentemente vales ao longo das falhas.

MORAES REGO (1940), interpretou a região do vale do Cubatão, como um sinclinal cujo núcleo seria constituido de rochas xistosas da parte superior do Precambriano Brasileiro.

F. RUELLAN (1944), relacionando a área aos seus estudos efetuado na Serra do Rio de Janeiro, admitiu que ela constituisse geomorfologicamente uma frente dissecada de blocos de falha.

ALMEIDA (1953), interpretou o relevo da Serra do Cubatão como um intenso $e$ demorado processo de erosão diferencial de adaptação das formas topográficas aos diversos tipos litológicos. Tal processo, teria se iniciado a partir de uma zona de falhamento ou forte flexura, ocorrido aquem da posição atual da escarpa, alguns quilômetros mar adentro. Os vales dos rios Cubatão e Mogi, seriam consequência da erosão de uma faixa de xistos, embutida entre gnaisses e migmatitos que sustentam as altas vertentes marginais.

Atualmente, admite-se que essa faixa, muito bem marcada ao longo do vale do Cubatão (Figura III.1.1.1.), seja preenchida por metassedimentos e tenha condicionamento estrutural no Falhamento de Cubatão. 
Esse falhamento, discutido em II.2., se desenvolveu durante a formação do Sistema Rift do Este Brasileiro, no período Jurássico/Início do Cretáceo, quando se delineou a borda continental brasileira.

A origem e evolução da Serra de Cubatão está portanto íntimamente ligada à formação e evolução da costa sudeste brasileira, com início há cerca de $150 \mathrm{Ma}$, tendo sido afetada por vários eventos posteriores de reativação tectônica Cenozóica.

O recuo das escarpas é governado pelas linhas estruturais e contactos litológicos das rochas precambrianas, com a abertura de grandes festonamentos na borda do Planalto Atlântico (CRUZ, 1975).

Tal evolução, prende-se aos processos geomórficos e seus mecanismos, típicos de áreas tropicais úmidas. Os altos índices pluviométricos, provocam $\circ$ constante escoamento superficial e subterrâneo, favorecendo assim a ação do intemperismo, tanto nos materiais superficiais, como em diversos níveis de alteração do susbstrato rochoso. A saturação dos materiais superficiais, especialmente nos verões onde ocorrem as chuvas mais intensas, aliada aos elevados valores de declividade das vertentes, provocam as ocorrências de escorregamentos e movimentos de massa, (exemplificados em I.1.), desgastando e modelando o relevo das encostas.

Os movimentos de massas nessas condições, conforme concordam vários autores (SHARPE, 1938; ZARUBA, 1969; CRUZ, 1990), devem ser reconhecidos como dos mais importantes processo geomórficos modeladores das encostas. Esses movimentos, ocorrendo em grandes extensões ou isoladamente, "fazem parte integrante do complexo processo erosivo formador das vertentes escarpadas", sendo intensificados sempre que interferem fatores antropogênicos.

O termo escarpa tem sido utilizado para vertentes com declividade superior a $22^{\circ}$, com segmentos retilíneos de mais de $60 \mathrm{~m}$, caracterizados por desníveis topográficas de pelo menos 40m (CRUZ, 1990), como ocorre via de regra na área da pesquisa. 


\section{IV.2. CARACTERÍSTICAS LOCAIS}

O mapa geomorfológico da área é apresentado na Figura IV.2.1.

Examinando a figura, podemos distinguir 3 províncias geomorfológicas bem distintas:

- Planalto Paulistano, no quadrante NW.

Faz parte do Planalto Atlântico, designação mais abrangente para o estudo da costa sudeste do Brasil. Possue relevo ondulado, com altitudes em torno de 700 a $750 \mathrm{~m}$ e acidentes topográficos de pequena amplitude, que excepcionalmente podem atingir até $1000 \mathrm{~m}$. As formas mamelonares com morrotes semi-arredondados, resultantes da ação intempérica, estâo entremeadas por cursos d'água de baixo gradiente hidráulico, que correm em várias direções.

A Fotografia IV.2.1. é uma vista de um trecho do Planalto Paulistano, junto à Represa do Rio das Pedras.

- Trecho Serrano, atravessando a área de SW para NE:

Caracteriza-se por um relevo muito acidentado e escarpado, com taludes muito inclinados, geralmente entre $35^{\circ}$ e $55^{\circ}$. O festonamento da linha principal de escarpa, a partir da borda do planalto, resultou numa sucessão de talvegues bastante entalhados no relevo, os quais se dispõe segundo as linhas de maior declive, buscando o rio Cubatão ou seus afluentes principais, os rios Pilões e Passareúva.

Os gradientes hidráulicos são muito elevados, geralmente superiores a $30^{\circ}$ e as amplitudes entre espigões e talvegues atingem até $60 \mathrm{~m}$.

Muitos desses talvegues apresentam-se secos a maior parte do tempo, entretanto transformam-se rapidamente em riachos caudalosos por ocasião das fortes chuvas características da região, especialmente no período de anual de outubro a março.

A Fotografia IV.2.2., dá uma visão parcial da escarpa serrana, que representa "um degrau com aproximadamente $700 \mathrm{~m}$ de altura", separando o Planalto Paulistano da Planície Costeira.

A Fotografia IV.2.3. é outra visão da Serra de Cubatão, em primeiro plano, com a Planície Costeira ao fundo. 
- Planície Costeira, no quadrante SE da área, de relevo plano e sujeita às oscilações de marés. Localmente restaram morrotes cristalinos isolados atingindo altitudes de 80 a $120 \mathrm{~m}$.

A Fotografia IV.2.4. é uma vista da Planície Costeira, tendo ao fundo a cidade de São Vicente.

Uma feição geomorfológica muito destacada na área é o vale do rio Cubatão que acompanha a direção geral da falha do mesmo nome. Ele está encaixada entre a escarpa principal da Serra de Cubatão e um alinhamento de cristas remanescentes ao sul do vale.

A escarpa da Serra tem sua borda superior muito bem marcada, em torno de 700$750 \mathrm{~m}$, se desenvolvendo na direção geral $\mathrm{NE}$ e apresentando uma reentrância na altura das cabeceiras do rio Pilóes, principal tributário do Cubatão na área.

A borda inferior da escarpa, embora menos marcante, tambem é bastante visivel, especialmente em fotos aéreas ao estereoscópio.

A linha de cristas que forma a vertente sul do vale do Cubatão, com cotas em torno de $700 \mathrm{~m}$, guarda a mesma direção geral das escarpas e vai decrescendo para $\mathrm{NE}$, até se transformar em morrotes isolados.

A ocorrência dessas cristas, parece ter similaridade com o fenômeno estudado por CAMPANHA (1994) no Planalto do Juqueriquerê, em São Sebastião, afastado cerca de $95 \mathrm{~km}$ na direçáo $\mathrm{NE}$, o qual é formado por uma sucessão de morros subnivelados, nas altitudes de 700 a $750 \mathrm{~m}$. 


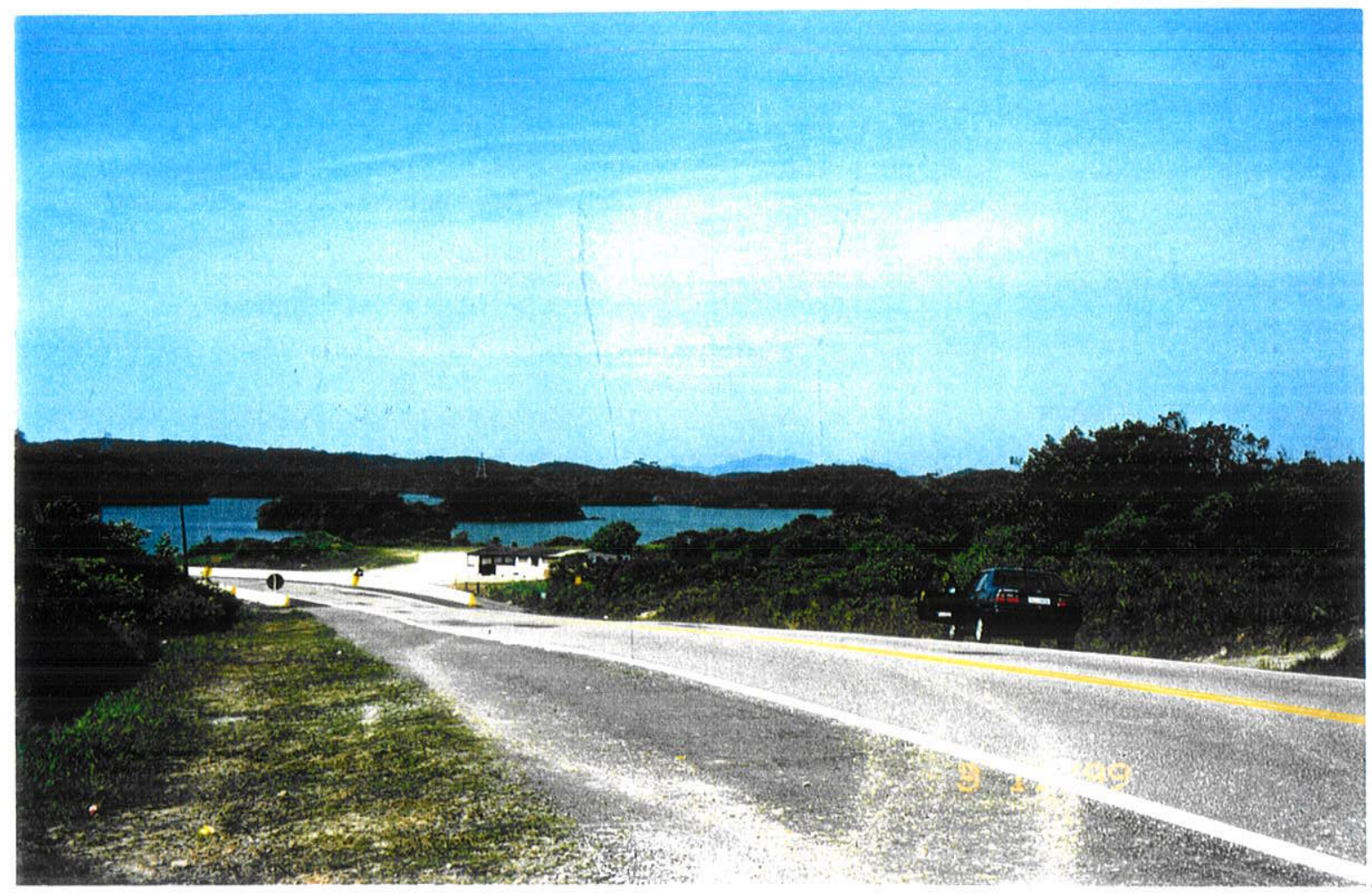

Fotografia IV.2.1. Planalto Paulistano. Vista parcial junto à Represa do Rio das Pedras

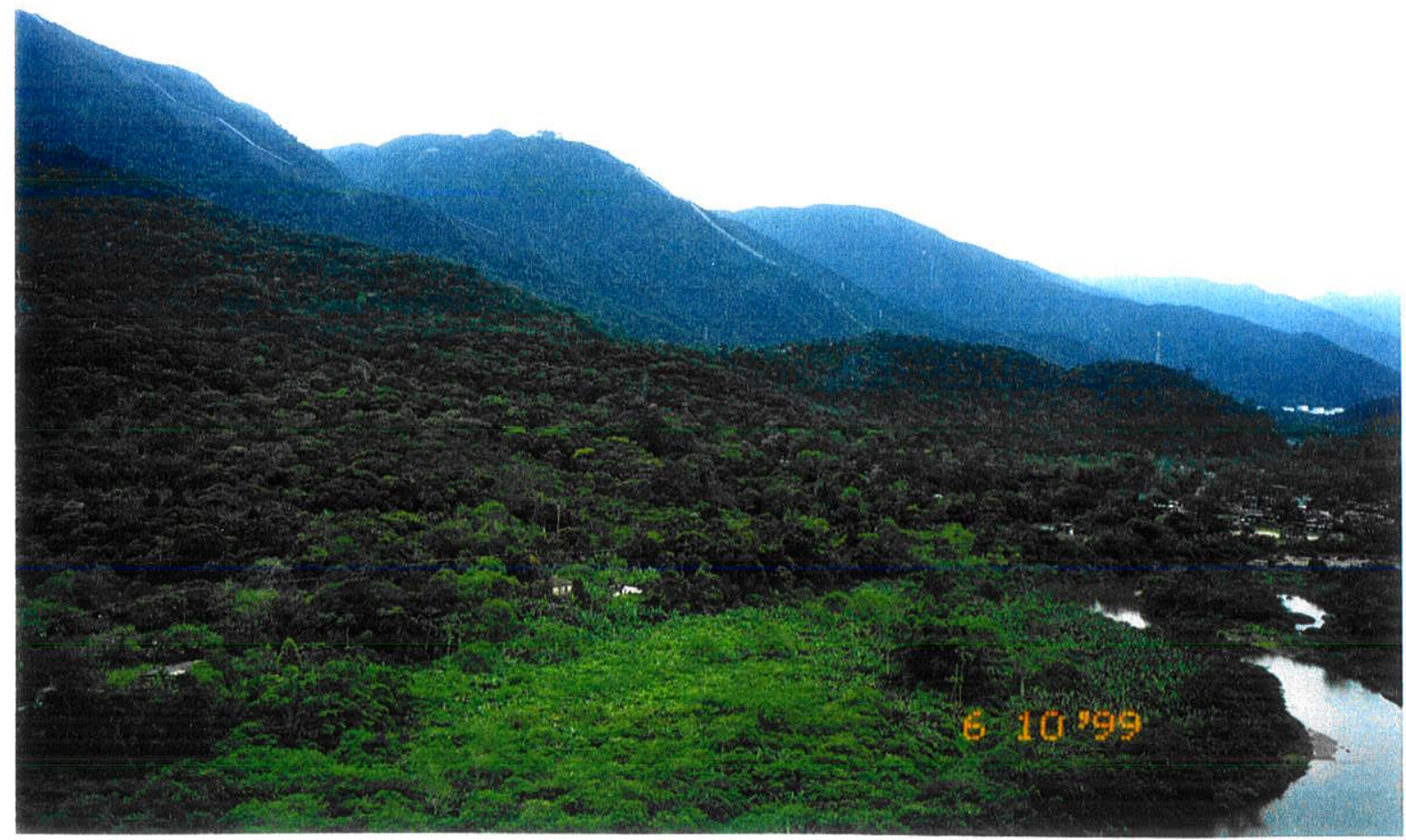

Fotografia IV.2.2. Serra de Cubatão. Visão geral da vertente do Caminho do Mar 


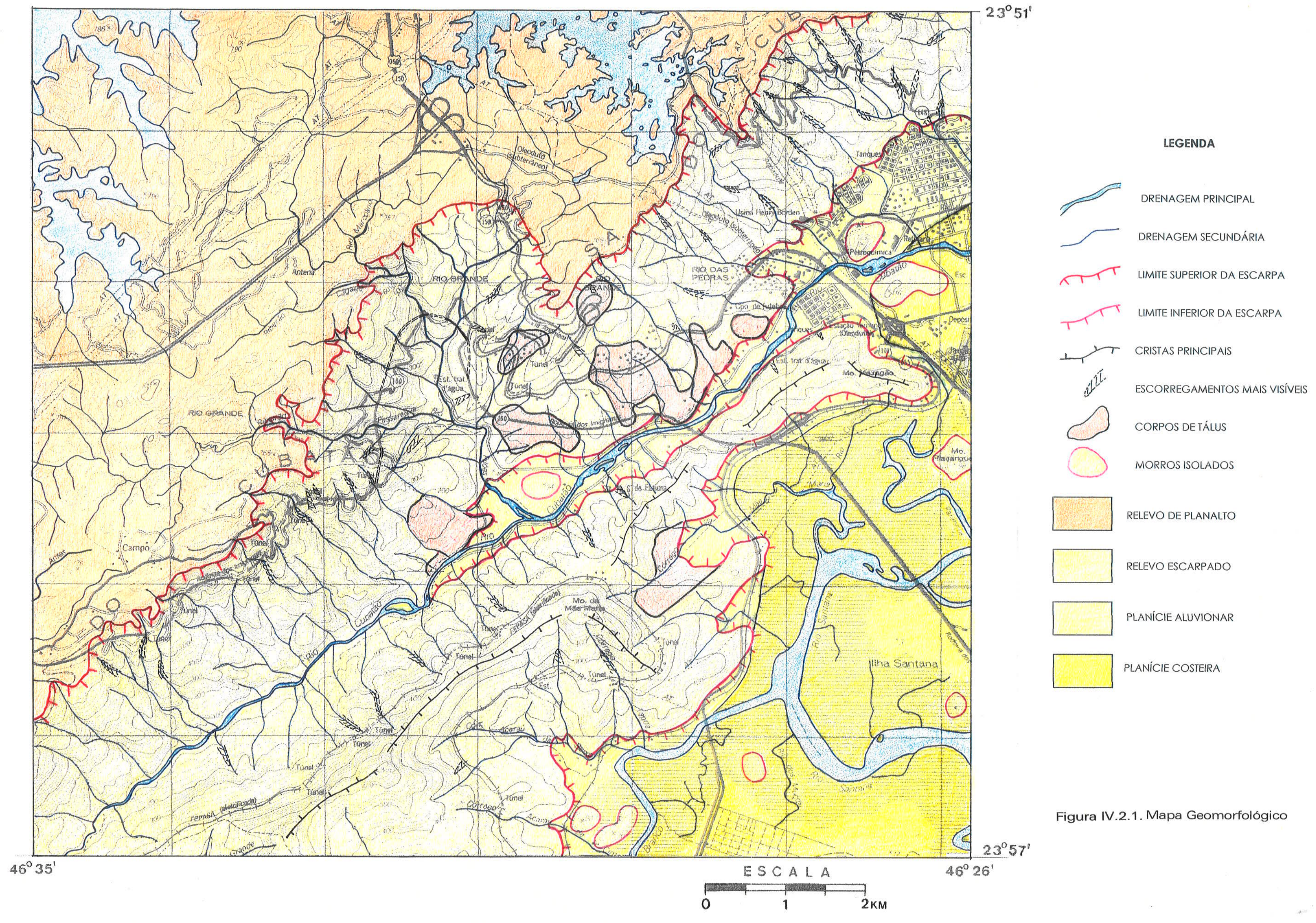




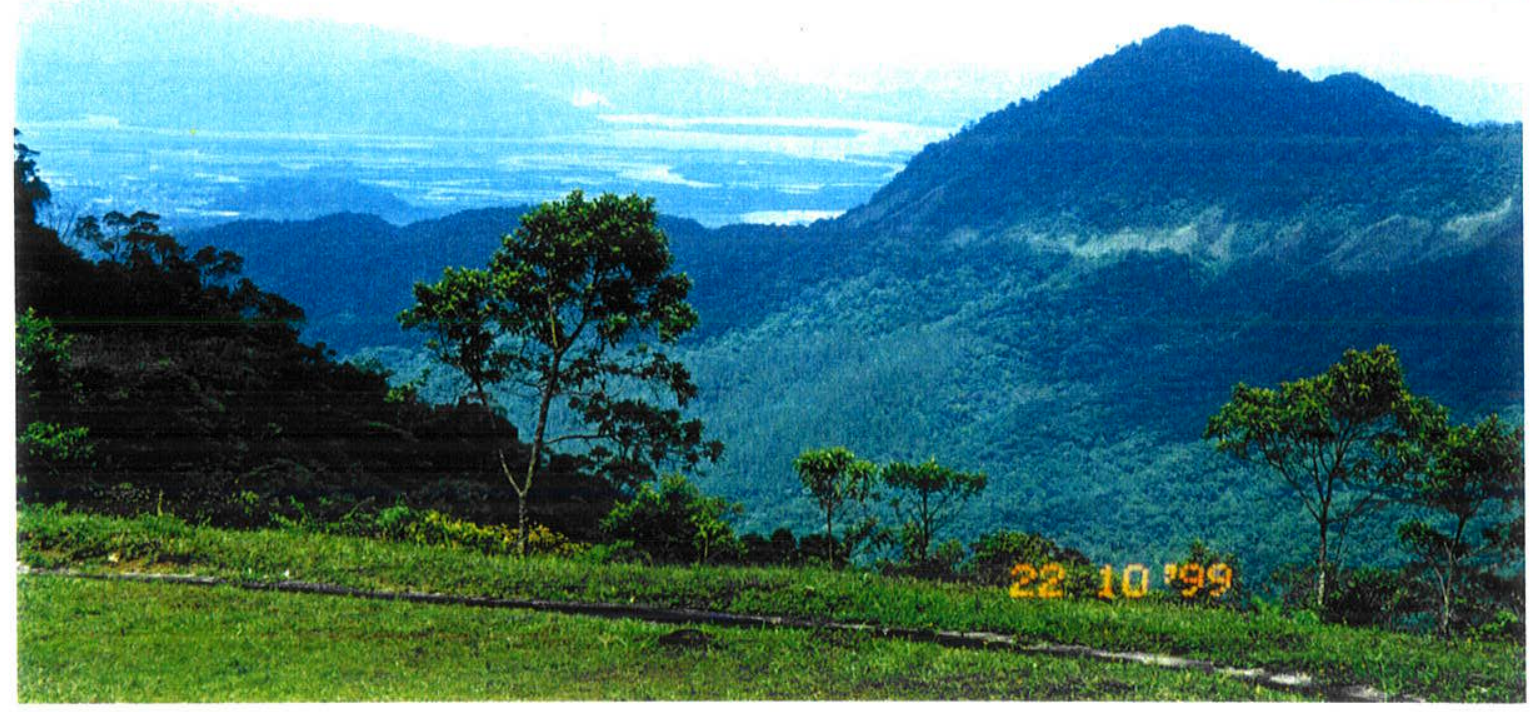

Fotografia IV.2.3. Serra de Cubatão. Vista da vertente direita do rio Cubatão, com Planície Costeira ao fundo

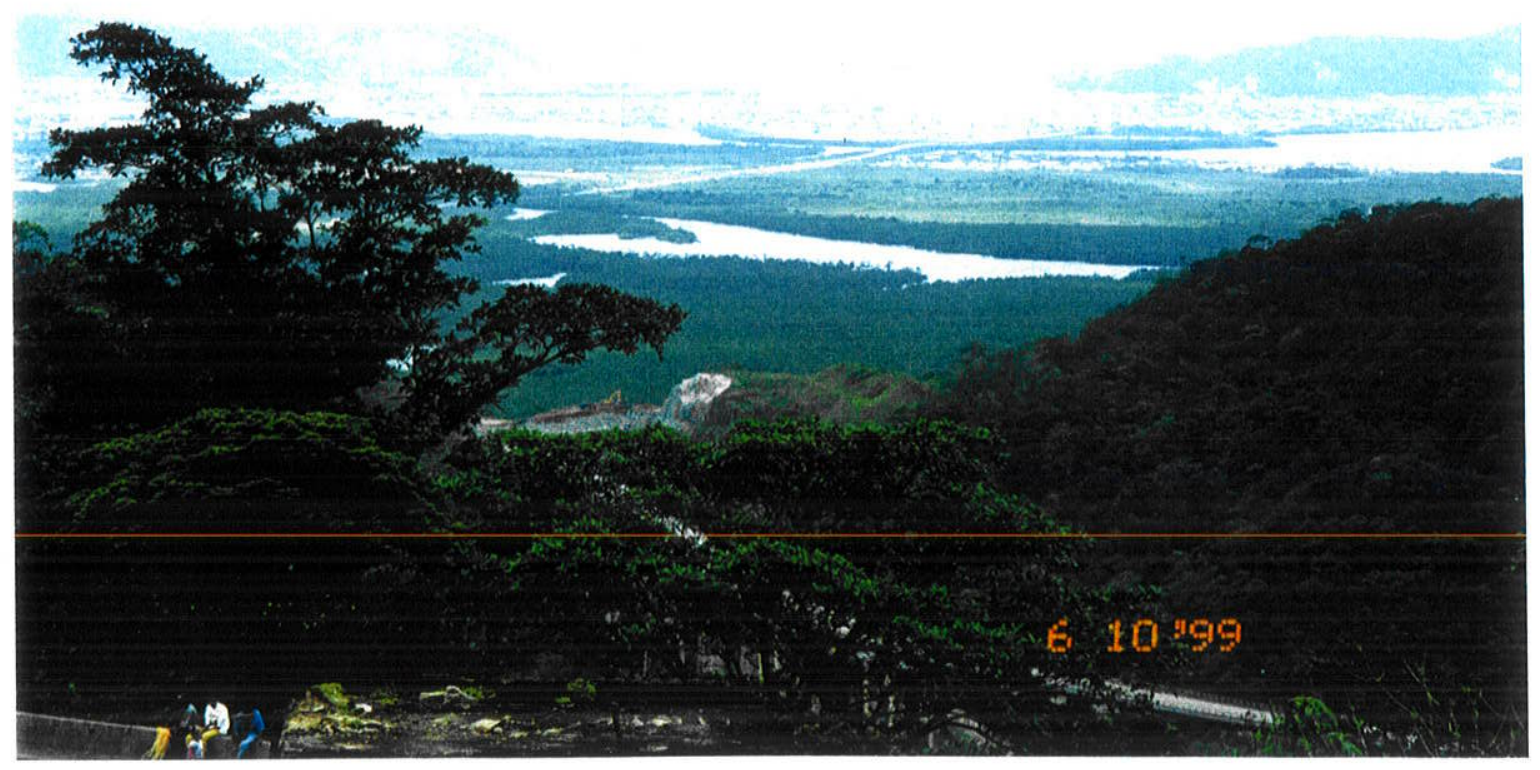

Fotografia IV.2.4. Planície Costeira. Vista parcial com a cidade de São Vicente ao fundo 


\section{IV.3. VISÃO LOCAL E DAS ÁREAS CIRCUNDANTES}

A Imagem IV.3.1., do satélite Landsat-5, 1995, nos dá uma ampla visão da área da pesquisa e das áreas circundantes.

A imagem cobre uma área total 8 vezes maior que a área de estudo, permitindo distinguir muitos elementos de interesse geral como relevo, hidrografia, sistemas viários, cidades, complexos industriais etc, incluindo tambem as principais feições da geomorfologia local anteriormente comentadas, bem como sua continuidade nas áreas circundantes, o que dá uma melhor visão de conjunto.

A sobreposição da transparência apresentada na Figura IV.3.1., aonde está delimitada a área da pesquisa, facilita a identificação dos elementos de maior interesse constantes da imagem Landsat, dentre os destacamos:

Relevo

- Limite Planalto - Serra;

- Limite Serra - Planície;

- Padrão diferenciado entre o Planalto Paulistano ("mar de morros"), Serra de Cubatão (escarpa) e Planície Costeira (topografia plana);

- Reentrâncias pronunciadas na borda serrana nas regióes dos vales dos rios Pilóes, Perequê, Mogi, Quilombo e Jurubatuba.

Hidrografia

- Represamentos no Planalto Paulistano (Billings, Rio Pequeno, Rio das Pedras);

- Rios Cubatão, Branco, Casqueiro, Perequê, Mogi, Quilombo, Jurubatuba, Piaçabuçu;

- Canais do Barreiros, Casqueiro, de Bertioga.

Sistema viário:

- Rodovia dos Imigrantes;

- Via Anchieta;

- Interligação Anchieta - Imigrantes;

- Caminho do Mar;

- FEPASA. 
Cidades:

- Cubatão;

- Santos;

- São Vicente;

- Vicente de Carvalho.

Complexos Industriais:

- COSIPA;

- Refinaria Presidente Bernardes.

Convem destacar ainda, atravessando toda a imagem, o Falhamento de Cubatão, orientado segundo a direção estrutural regional principal: $\mathrm{N} 50^{\circ}-60^{\circ} \mathrm{E}$.

Muitos outros elementos, constam da imagem apresentada e podem ser analisados, dependendo do enfoque que se considere.

Utilizando-se técnicas de processamento digital de imagens, a partir da gravação original em fita magnética, pode-se pesquisar e obter muitas informações.

Um exemplo de resultado, obtido com processamento digital de imagem de satélite em laboratório, já foi apresentado na Imagem 1.3.1., onde está muito bem diferenciado o padrão visual entre o Planalto Paulistano, a Serra de Cubatão e a Planície Costeira. 


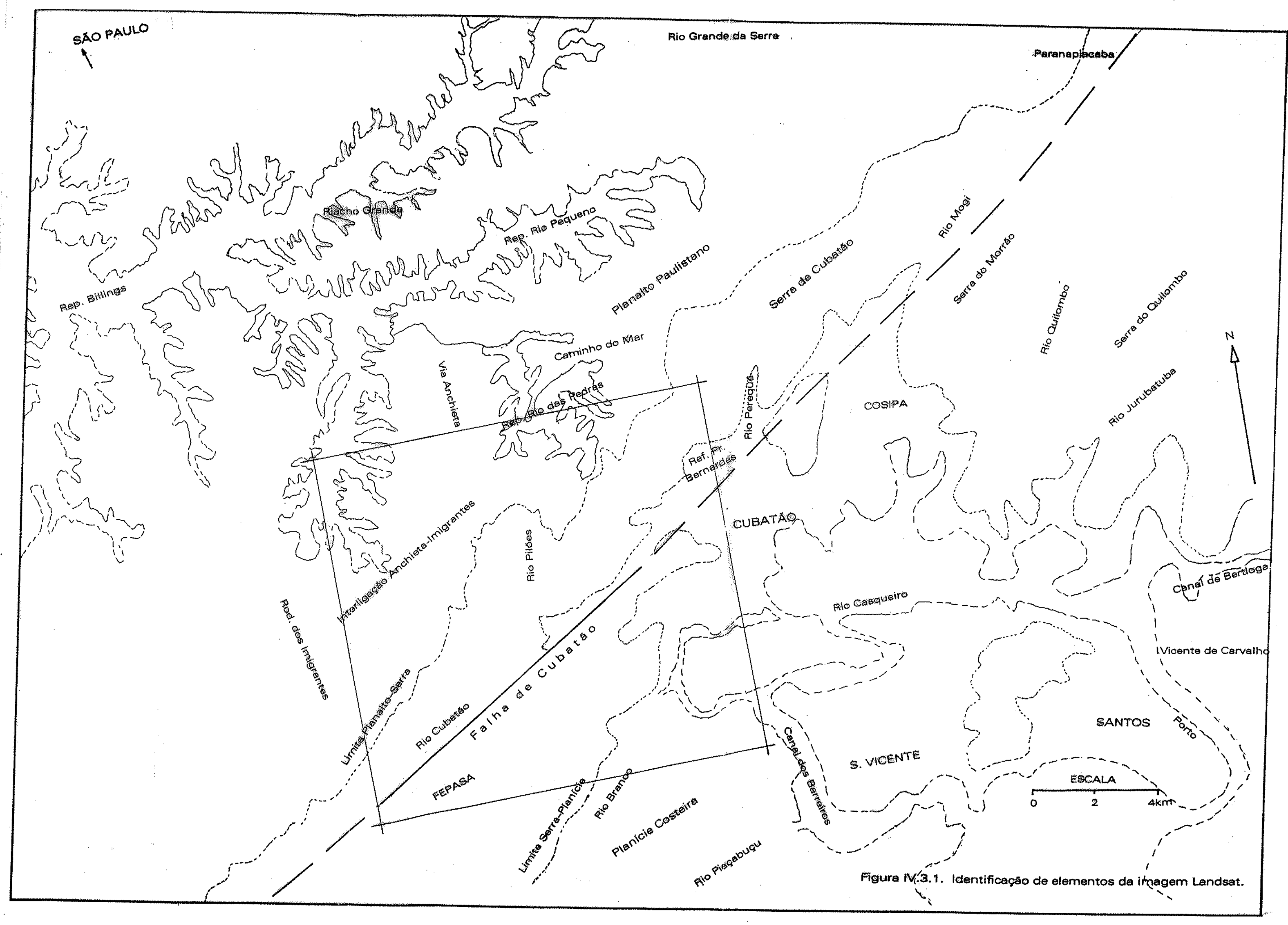




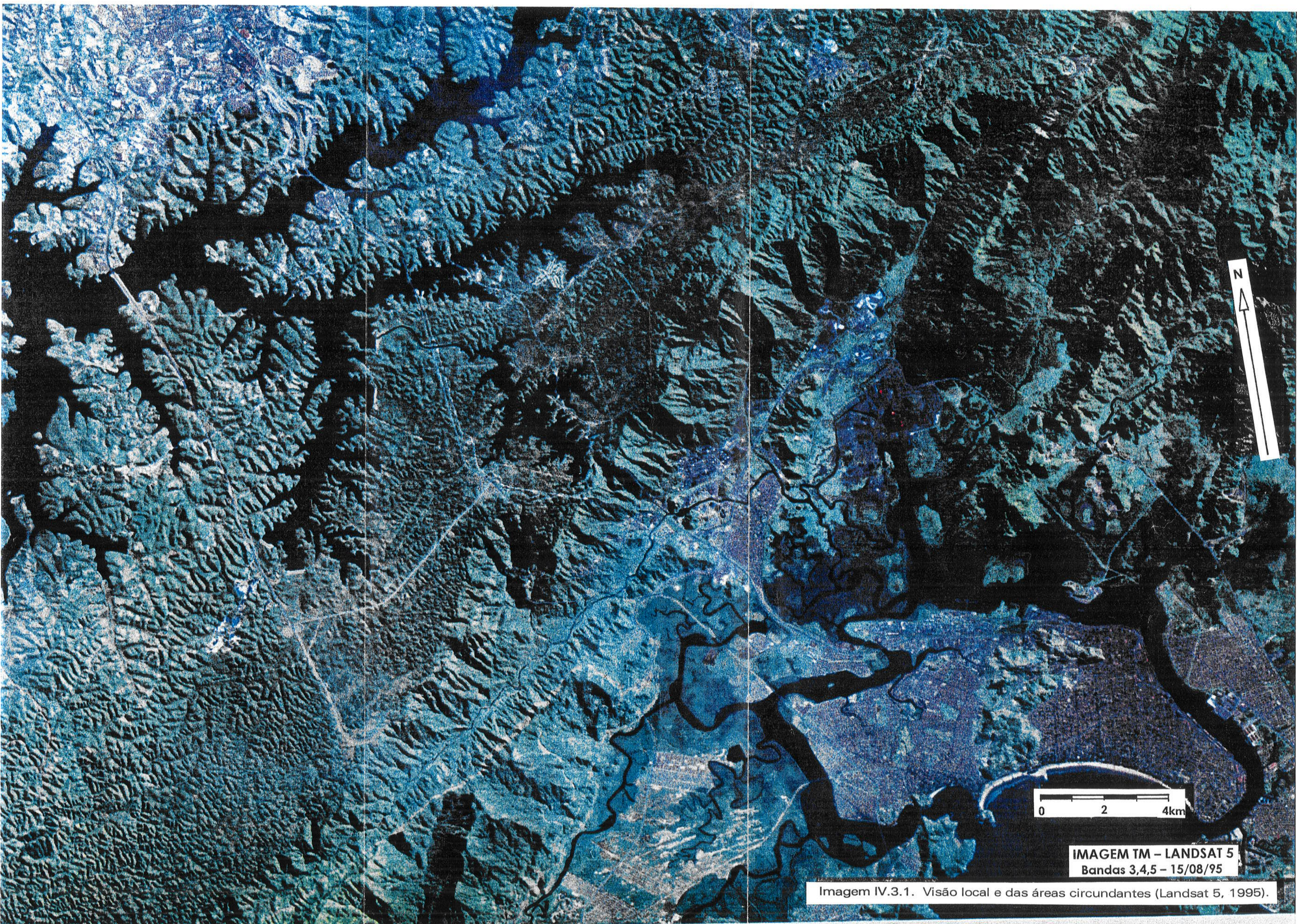




\section{CAṔ́tULO $v$}

\section{CLIMA, PLUVIOMETRIA E VEGETAÇÃo}

\section{V.1. CONSIDERAÇÕES SOBRE O CLIMA E INFLUÊNCIA DA PLUVIOMETRIA.}

Existem algumas cartacterísticas diferenciadas entre os climas das 3 províncias geomorfológicas mencionadas anteriormente: Planalto, Serra e Planície Costeira. Vamos nos ater ao trecho da Serra de Cubatão, que tem especial interesse para este trabalho, onde o clima se caracteriza por elevados índices pluviométricos, grande nebulosidade e temperatura média anual superior a $22^{\circ} \mathrm{C}$.

A média mensal das temperaturas é superior a $18^{\circ} \mathrm{C}$ nos meses mais frios e superior a $22^{\circ} \mathrm{C}$ nos meses mais quentes.

A área apresenta um clima de transição, entre 2 tipos classificados por KOEPPEN:

Af - chuva contínua durante todo $o$ ano, sem estação seca;

Aw - chuva se concentrando mais no verão e chuvas ocasionais no inverno.

De modo geral, o clima apresenta características do tipo "Tropical Chuvoso".

A umidade relativa do ar é sempre elevada, comumente acima de $85 \%$. Essa característica, aliada à temperatura média anual elevada, favorece grandemente o desenvolvimento da flora em geral.

A névoa e chuviscos típicos dessa região serrana se devem à condensação de água das massas de ar carregadas de umidade provenientes do Oceano Atlântico, ao encontrarem a barreira climática representada pela escarpa da Serra do Cubatão.

O período conhecido como "estação das águas", se estende de outubro a março/abril, quando ocorre $70 \%$ da precipitação pluviométrica anual.

Os índices pluviométricos na área serrana são dos mais elevados do País, alcançando frequentemente valores superiores a $3500 \mathrm{~mm} / \mathrm{ano}$.

Excepcionalmente, podem atingir valores superiores a $4000 \mathrm{~mm} / \mathrm{ano}$, como ocorreu em 1976, quando os índices seguintes foram registrados:

- 4152 mm na Estação Pluviométrica E-143 na Cota 400 (Via Anchieta);

- $4408 \mathrm{~mm}$ na Estação Pluviométrica E-153, na Curva da Onça (cota $500 \mathrm{~m}$ da Via Anchieta) 
A Figura V.1.1., mostra a localização de 5 estações pluviométricas existentes na área de interesse para o trabalho:

- Estação E-109 ALTO DA SERRA, altitude de 760m;

- Estação E-153 CURVA DA ONÇA, Via Anchieta, altitude de 500m;

- Estação E-143 COTA 400, Via Anchieta, altitude de 400m;

- Estação E-236 PILÕES, altitude de 100m;

- Estação E 101 CUBATÃo. altitude de 06m.

A Tabela V.1.1., apresenta as alturas anuais de chuvas registradas nas 5 estações pluviométricas citadas, no período 1976-1991.

Conforme se depreende da tabela apresentada, os meses mais chuvosos são janeiro e fevereiro, sendo agosto o mês mais seco.

Os maiores índices pluviométricos foram registrados pelas estações E-153, na Curva da Onça e E-143, na Cota 400, ambas de especial interesse por estarem localizadas em plena escarpa serrana.

Os registros mais completos se referem à Cota 400, porém se observarmos os 3 únicos índices registrados na Curva da Onça, verificaremos que eles são comparativamente superiores. Este último local é provavelmente o de maior incidência pluviométrica na área da pesquisa. Registros de campo, atualmente desaparecidos mas de conhecimento do autor, entre 1976 e 1985 indicavam essa tendência. 


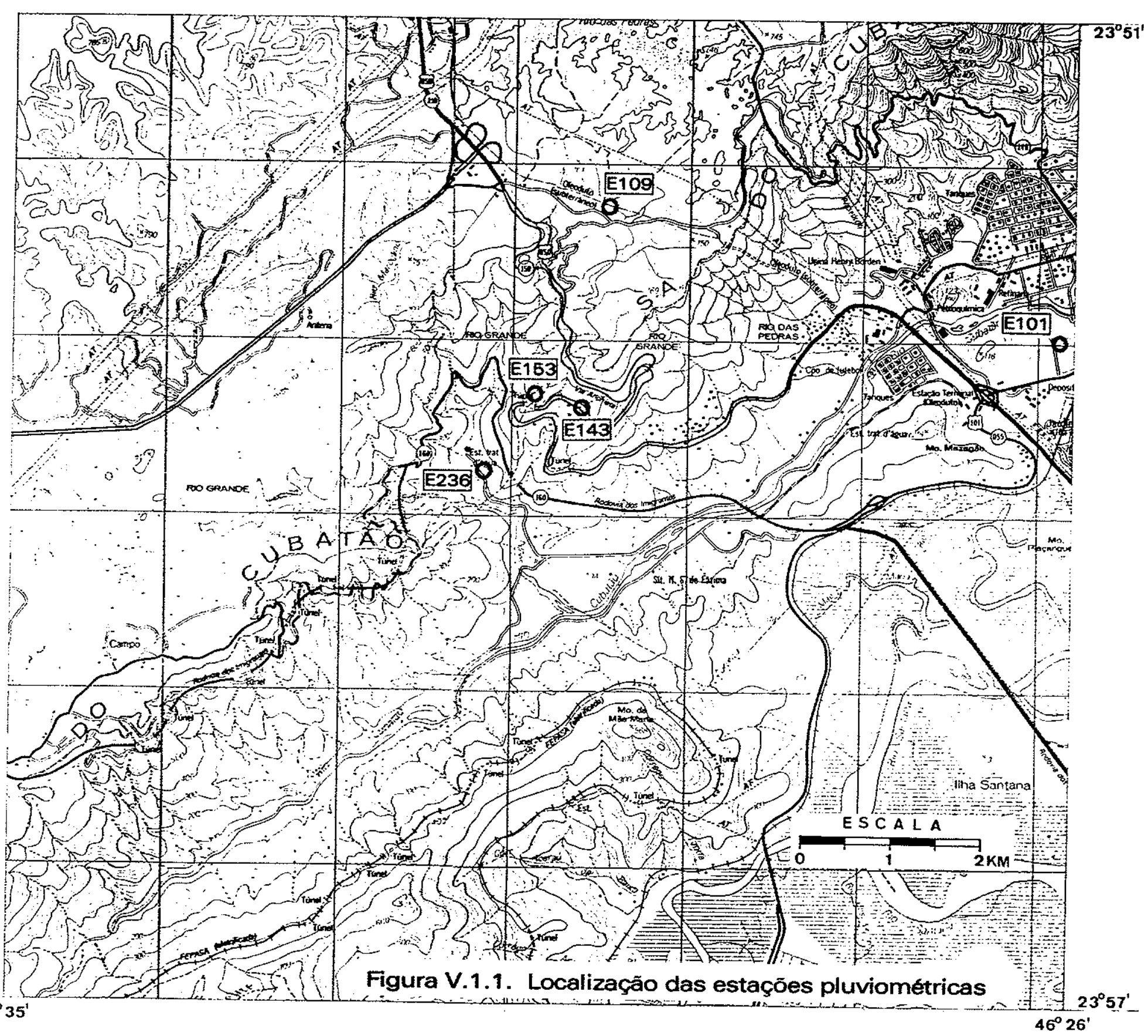


Tabela V.1.1. Alturas anuais de chuvas (mm), 1976-1991 (DAEE/CTH,1997)

\begin{tabular}{|c|c|c|c|c|c|c|c|c|}
\hline ANO & $\begin{array}{c}\text { E-109 } \\
\text { ALTO DA } \\
\text { SERRA } \\
\text { (Alt. } 760 \mathrm{~m} \text { ) }\end{array}$ & $\begin{array}{c}\text { E-153 } \\
\text { CURVA DA } \\
\text { ONÇA } \\
\text { (Alt. } 500 \mathrm{~m} \text { ) }\end{array}$ & $\begin{array}{c}\text { E-143 } \\
\text { COTA } 400 \\
\text { (Alt. } 400 \mathrm{~m} \text { ) }\end{array}$ & $\begin{array}{c}\text { E-236 } \\
\text { PILÕES } \\
\text { (Alt. } 100 \mathrm{~m} \text { ) }\end{array}$ & $\begin{array}{c}\text { E-101 } \\
\text { CUBATÃO } \\
\text { (Alt. 06m) }\end{array}$ & $\begin{array}{c}\text { Mês } \\
\text { mais } \\
\text { chuvoso }\end{array}$ & $\begin{array}{l}\text { Mês } \\
\text { mais } \\
\text { seco }\end{array}$ & OBS. \\
\hline 1976 & - & 4408 & 4152 & - & 3202 & JAN & JUN & Várias Estaçōes \\
\hline 1977 & - & 3681 & 3596 & 3293 & 2426 & $A B R$ & JUL & pluviométricas (E) \\
\hline 1978 & 2542 & - & 2640 & - & 2089 & NOV & AGO & ficaram sem a \\
\hline 1979 & - & - & - & - & 2401 & NOV & JUN & totalização anual, \\
\hline 1980 & - & - & 2878 & 2840 & - & FEV & MAl & nos anos em que \\
\hline 1981 & - & - & 3109 & - & 2247 & JAN & SET & ocorreram falhas \\
\hline 1982 & 2865 & - & 3497 & - & 2436 & NOV & AGO & nos registros \\
\hline 1983 & 3353 & - & 3575 & 3637 & 3197 & FEV/MAR & AGO & mensais \\
\hline 1984 & 2362 & 2667 & 2593 & 2336 & 1854 & NOV & JUN & \\
\hline 1985 & - & - & - & - & 2105 & JAN & JUL & \\
\hline 1986 & - & - & 3814 & 3756 & 2886 & DEZ & JUN & \\
\hline 1987 & - & - & - & 2554 & 2228 & JAN & JUL/AGO & \\
\hline 1988 & - & - & 3950 & - & 2822 & FEV & AGO & \\
\hline 1989 & - & - & - & 3213 & 2743 & FEV & AGO & \\
\hline 1990 & - & - & 3102 & 2291 & 2292 & ABR & AGO & \\
\hline 1991 & 2223 & - & - & - & 2531 & MAR & AGO & \\
\hline
\end{tabular}


Consultando os registros pluviométricos mensais disponiveis e relativos à estação $\mathrm{E}$ 143 na Cota 400 (DAEE/CTH, 1997), destacamos os seguintes valores mais expressivos:

- Janeiro/76 .......... $1037 \mathrm{~mm}$

- Abril/77 ............. $607 \mathrm{~mm}$

- Janeiro/85 .......... $633 \mathrm{~mm}$

- Dezembro/86 ...... $623 \mathrm{~mm}$

- Fevereiro/88 ....... $681 \mathrm{~mm}$

- Fevereiro/89 ....... $695 \mathrm{~mm}$

- Março/91 ............ 879 mm

Para essa mesma estação, o registro mensal mais baixo encontrado, foi de $18 \mathrm{~mm}$, relativo a Julho/85.

O relatório geral para $O$ projeto de engenharia da Rodovia dos Imigrantes (ESCRITÓRIO TEC. J. C. F. FERRAZ, 1971), cita chuvas torrenciais excepcionais atingindo o valor de $400 \mathrm{~mm}$ em 24 horas, na encosta da Estrada de Ferro Sorocabana (atual FEPASA), na vertente direita do rio Cubatão, não especificando entretanto a data.

Um ábaco muito interessante foi preparado por TATIZANA et al, em 1987, correlacionando a intensidade de chuvas com os escorregamentos induzidos na Serra do Mar, município de Cubatão, conforme apresentado na FIGURA V.1.2.

A figura mostra uma curva exponencial que é a envoltória dos pontos com maior probabilidade da ocorrência de escorregamentos.

Todos os pontos plotados no gráfico correspondem a locais com atividade antrópica, pesquisados no trecho serrano do município de Cubatão, razão pela qual fala-se em escorregamentos induzidos.

No eixo das ordenadas estão marcadas as intensidades de chuvas, em $\mathrm{mm} / \mathrm{h}$ e, no eixo das absissas, as chuvas acumuladas nos três dias anteriores ao evento pluviométrico considerado, em mm. Cruzando-se os dados Ordenada X Abcissa, encontramos um ponto que pode corresponder a um evento de escorregamento induzido (dentro da envoltória), ou a um evento sem registro de escorregamento (fora da envoltória). 


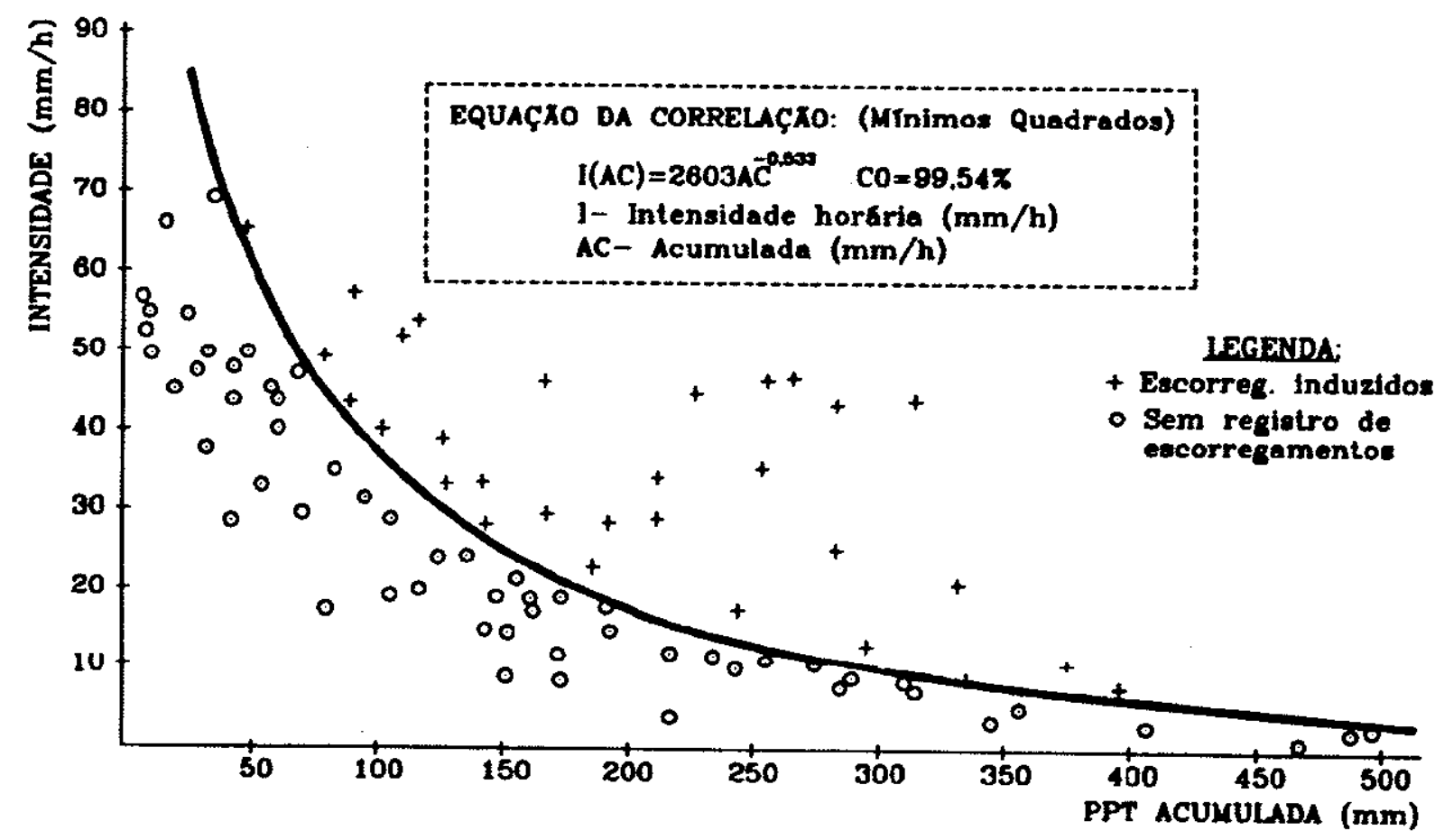

Figura V.1.2. Correlação entre chuvas e escorregamentos na Serra do Mar, município de Cubatão (Tatizana et al, 1987). 


\section{V.2. CONSIDERAÇÕES SOBRE O TIPO E INFLUÊNCIA DA VEGETAÇÃO}

A floresta na Serra de Cubatão, tem sofrido, especialmente nas três últimas décadas, os efeitos deletérios dos poluentes industriais provenientes do Polo petroquímico e siderúrgico de Cubatão e Piaçaguera.

Esse efeito se faz sentir em toda a floresta, mas de forma mais acentuada nas cotas acima de $350 \mathrm{~m}$ onde é maior a pluviosidade, notadamente nas vertentes mais próximas dos centros poluidores, como se observa nas encostas do Caminho do Mar, onde a vegetação tem sido bastante afetada. As nuvens carregadas de poluentes, trazidas pelos ventos que provem do mar, provocam a formação de "chuvas ácidas" ( $\mathrm{pH}$ inferior a 5), muito prejudiciais à vegetação.

Observam-se sinais de doenças - necroses e cloroses - com sintomas típicos de lesão por cloro/fluor e ozônio (GUTBERLET, 1996). Espessas camadas de partículas de aparência preta e oleosa são acumuladas nas superfícies das folhas.

Devido aos poluentes, incluindo o dióxido de enxofre e dióxido de nitrogênio, ocorre uma acentuada perda de folhas e a diminuição da biodiversividade de espécies, permanecendo aquelas mais resistentes, como: quaresmeiras, Cecropia, Tibouchira, Micônia, Helicônia,sp, Maranta sp, Piper sp, Philodendron (imbé), Rhipsalis, Epiphyllum, Mikania lagunosa e diversas espécies de gramíneas.

São encontrados muitos troncos de grandes árvores mortas e em várias áreas, observa-se a tendência de prevalecer a vegetação arbustiva. Não tem sido observado o crescimento de novas espécies arbóreas.

Quanto aos ventos provenientes do Planalto Paulistano soprando em direção ao mar, tem influência de apenas $5 \%$ a $10 \%$ no conjunto das condições meteorológicas locais (segundo o autor acima). Entretanto, tambem constituem fator degenerativo da flora, pois tem uma ação permanente, carregando poluentes provenientes das indústrias dos municípios do $\mathrm{ABC}$ e Mauá.

A flora da mata-de-encosta atlântica que reveste a Serra de Cubatão é composta por uma vegetação extremamente diversificada em espécies, pertencentes à "Floresta Latifoliada Tropical Úmida de Encostas" (GONÇALVES, 1995).

Trata-se de uma floresta de formação vegetal umbrófila com os condicionantes de ambiente tropical e que, apesar de luxuriante é dotada de grande fragilidade ante às perturbações antrópicas. 
O equlíbrio do ecossistema, formado por comunidades muito complexas, mostra-se bastante sensível e está sendo rompido pelas ações resultantes da atividade humana (obras de engenharia, ocupação irregular, desmatamento, poluição química etc.).

Nas Fotografias V.2.1 e V.2.2., podemos observar respectivamente, um aspecto geral da mata e uma área com indícios de degradação vegetal.

Predominam na flora original da Serra de Cubatão, as espécies lenhosas fanerogâmicas, formando os estratos superiores, escalonados e bastante densos. Essa disposição dificulta a passagem dos raios solares, os quais atingem o solo de forma muito escassa, criando um ambiente de sombra propício para o surgimento de espécies umbrófilas (marantas, helicônias, begônias, samambaias e musgos) que revestem o piso da mata. Sobre esse dossel arbóreo, se desenvolvem espécies herbáceas semi-lenhosas heliófilas, do tipo trepadeiras. Fazem parte ainda dessa diversidade, lianas, bromélias, cactos e orquídeas, que crescem sobre os troncos e ramos das árvores.

Com a degradação vegetal, esse panorama vai sendo modificado, com diminuição das espécies em geral, em particular das espécies arbóreas.

A degeneração gradativa do revestimento vegetal das encostas, inclusive com $\circ$ enfraquecimento da trama de raízes e rizomas que servem como travamento dos solos, especialmente durante as chuvas, implica na diminuição da sua resistência ao cisalhamento, aumentando consequentemente sua susceptibilidade aos escorregamentos.

Observações visuais em áreas afetadas por escorregamentos mostraram que as raízes, mesmo de grandes árvores, são pouco profundas, com penetração geralmente restrita ao solo coluvial, ou penetrando pouco no solo saprolítico muito pobre em nutrientes. Ainda assim, seu papel no travamento dos solos não pode ser menosprezado. 


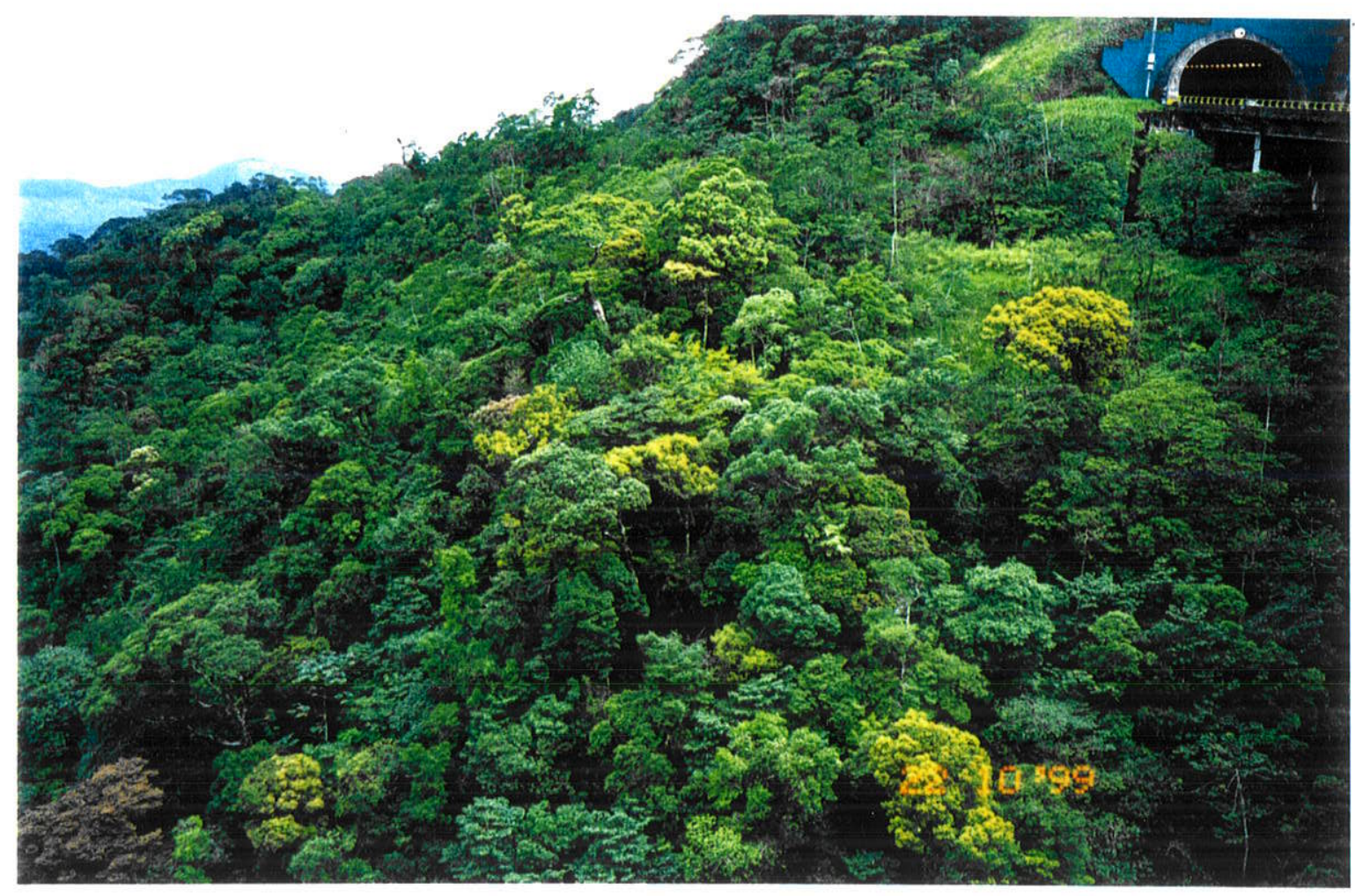

Fotografia V.2.1. Aspecto geral da mata na Serra de Cubatão

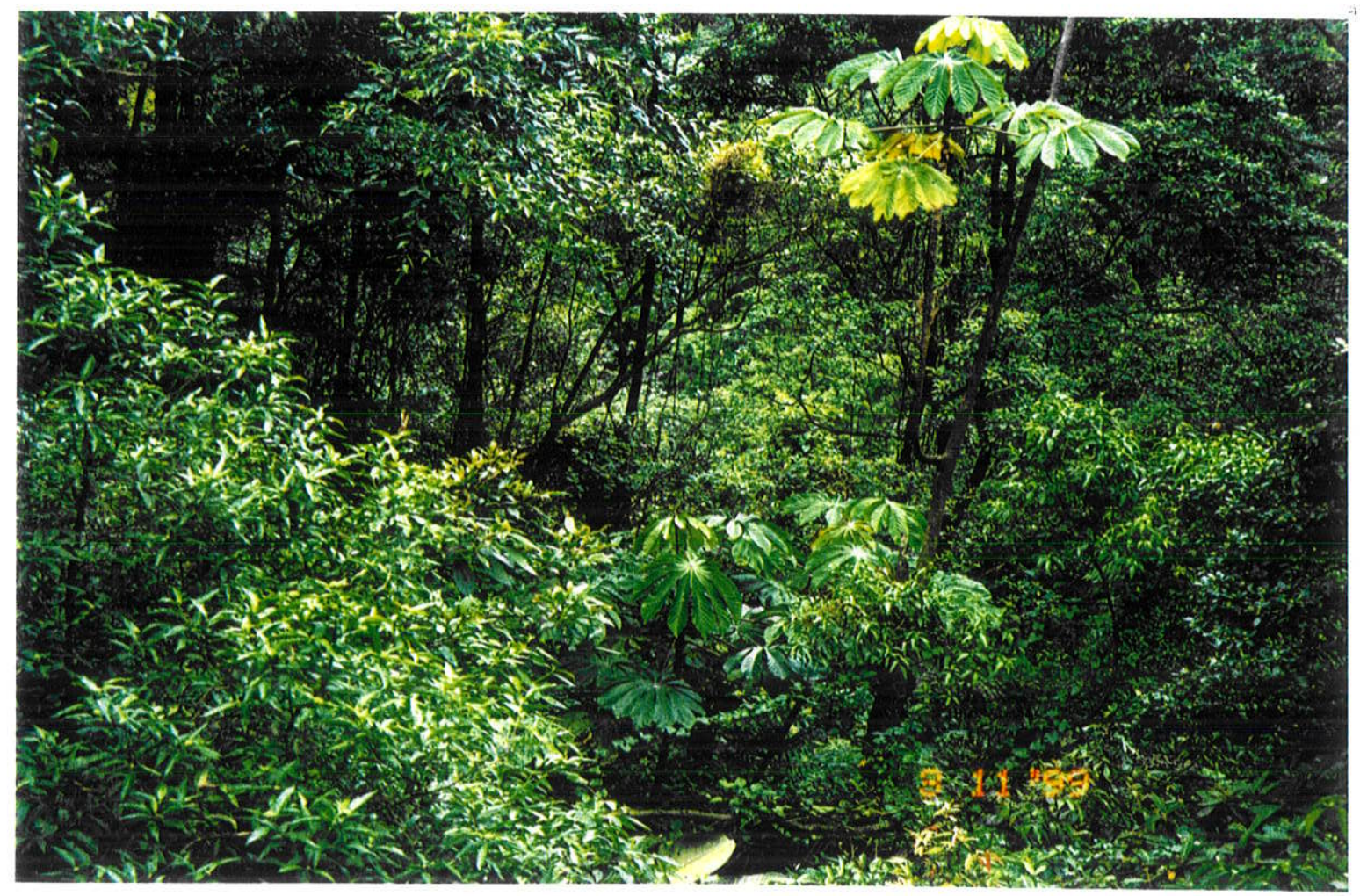

Fotografia V.2.2. Área com indícios de degradação vegetal 
WOLLE, 1987, elaborou um gráfico correlacionando o desmatamento com a variação esquemática de estabilidade das encostas, expressas pelo seu fator de segurança (FS = relação entre as forças resistentes num bloco ideal de encosta e as forças cisalhantes atuantes no mesmo bloco), conforme apresentado na Figura V.2.1..

Verifica-se na figura, que existe uma linha de tendência natural da estabilidade da encosta antes do desmatamento, com um determinado ângulo de inclinação $(\Delta \mathrm{FS} / \Delta \mathrm{t}$ Florestado). Essa linha é modificada após o desmatamento, assumindo um ângulo mais inclinado ( $\Delta \mathrm{FS} / \Delta \mathrm{t}$ Desmatado), o que leva à ruptura da encosta num tempo total inferior ao que seria sem o desmatamento.

Observa-se que, imediatamente após o desmatamento, ocorre um acréscimo de estabilidade devido à eliminação de fatores desfavoráveis como sobrecarga da vegetação, efeito alavanca, etc. Entretanto, esse acréscimo tende a desaparecer com o tempo, à medida que ocorrem o apodrecimento das raizes, com consequente perda da trama de travamento dos solos, bem como de outros fatores favoráveis, como a redistribuiçao da água das chuvas e proteção superficial, anteriormente proporcionados pela vegetação.

Não podemos deixar de ressaltar que, descontado o efeito deletério da poluição química, as condições de clima, temperatura e umidade, favorecem grandemente a regeneração da vegetação em geral, que em poucos anos, tende a ocupar seus espaços nas aréas afetadas pelo homem ou por escorregamentos naturais.

Em locais onde a construção da Rodovia dos Imigrantes provocou destruição da vegetação,. foram tomados cuidados para a sua recuperação, após a abertura da estrada. Cerca de 4 anos depois, a vegetação arbustiva já cobria completamente as cicatrizes da construção, estando a vegetação arbórea em fase inicial de desenvolvimento.

Para intervalos de tempo maiores, observa-se a recuperação da floresta, conforme ilustrado nas Fotografias V.2.3. e V.2.4., tiradas em nov/1974 e out/1999, respectivamente.

Considerando-se o gráfico anteriormente apresentado, significa que, alguns anos após o desmatamento, à medida que vai havendo a regeneração progressiva da flora, vai tambem se restabelecendo a linha de tendência natural da estabilidade. 


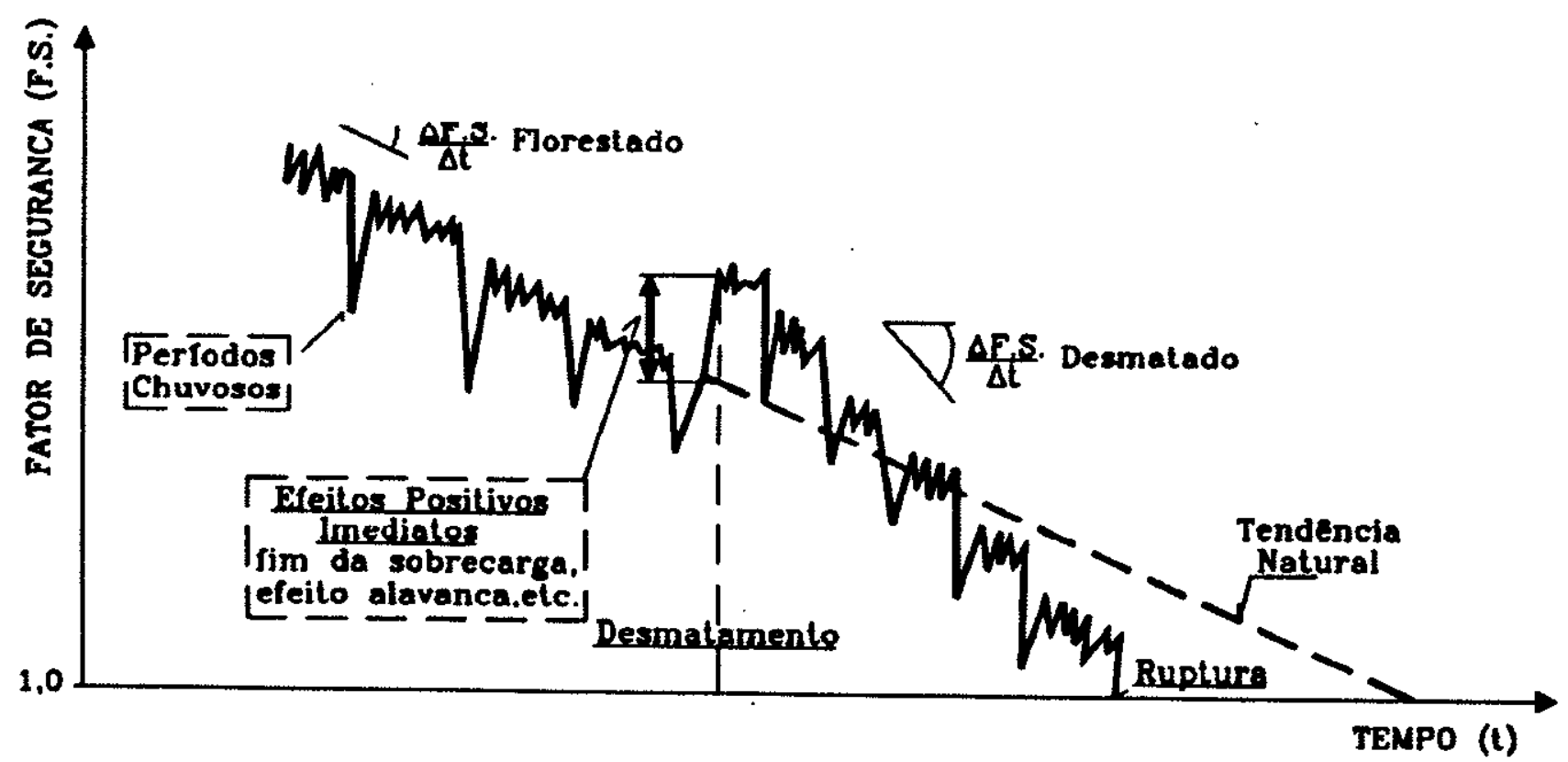

Figura V.2.1. Desmatamento e variação esquemática da estabilidade das encostas (Wolle, 1986). 


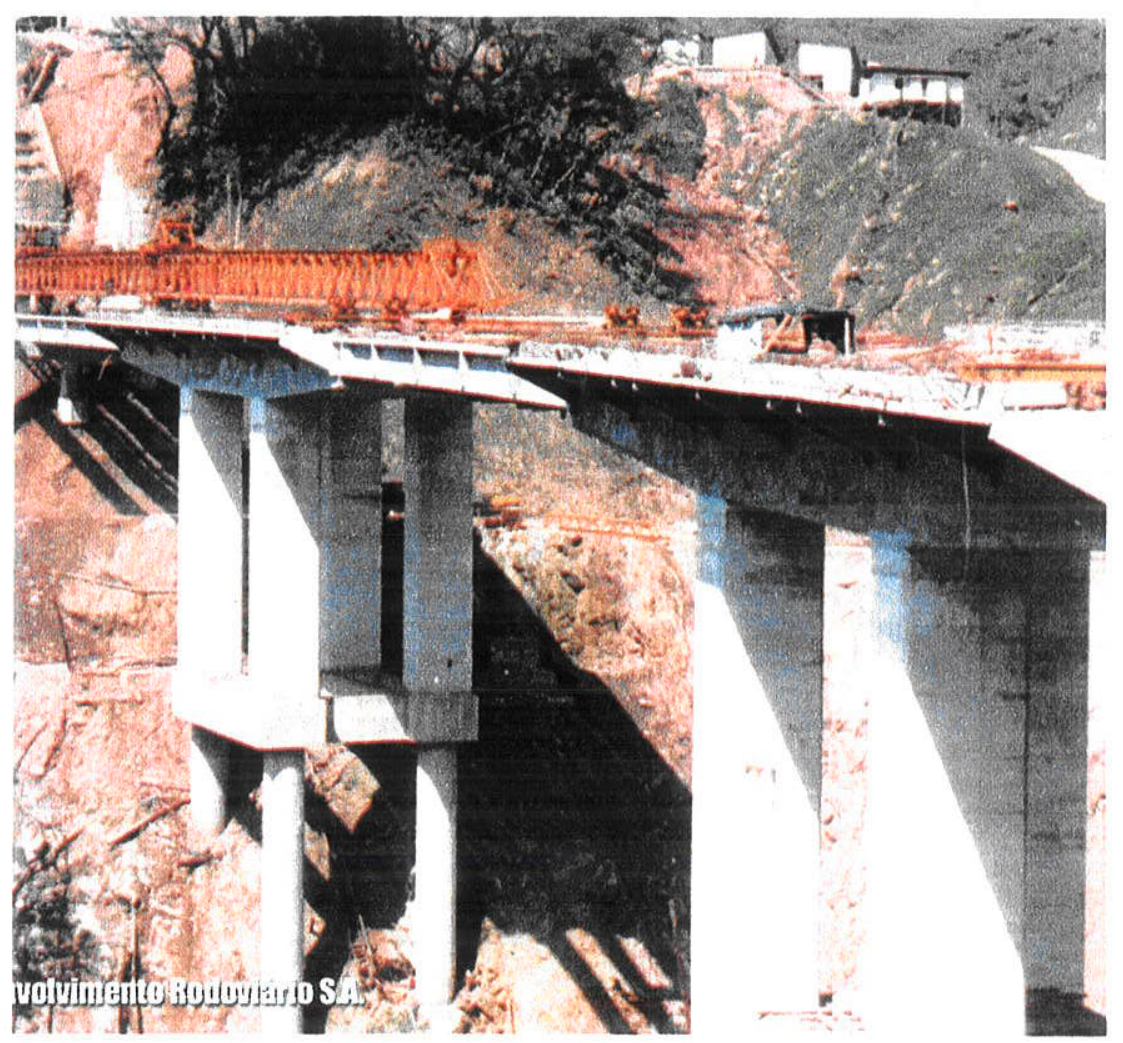

Fotografia V.2.3. Vegetação destruida na encosta do viaduto VA-5 da Rodovia dos Imigrantes, Nov/1974 (Desenvolvimento Rodoviário SA)

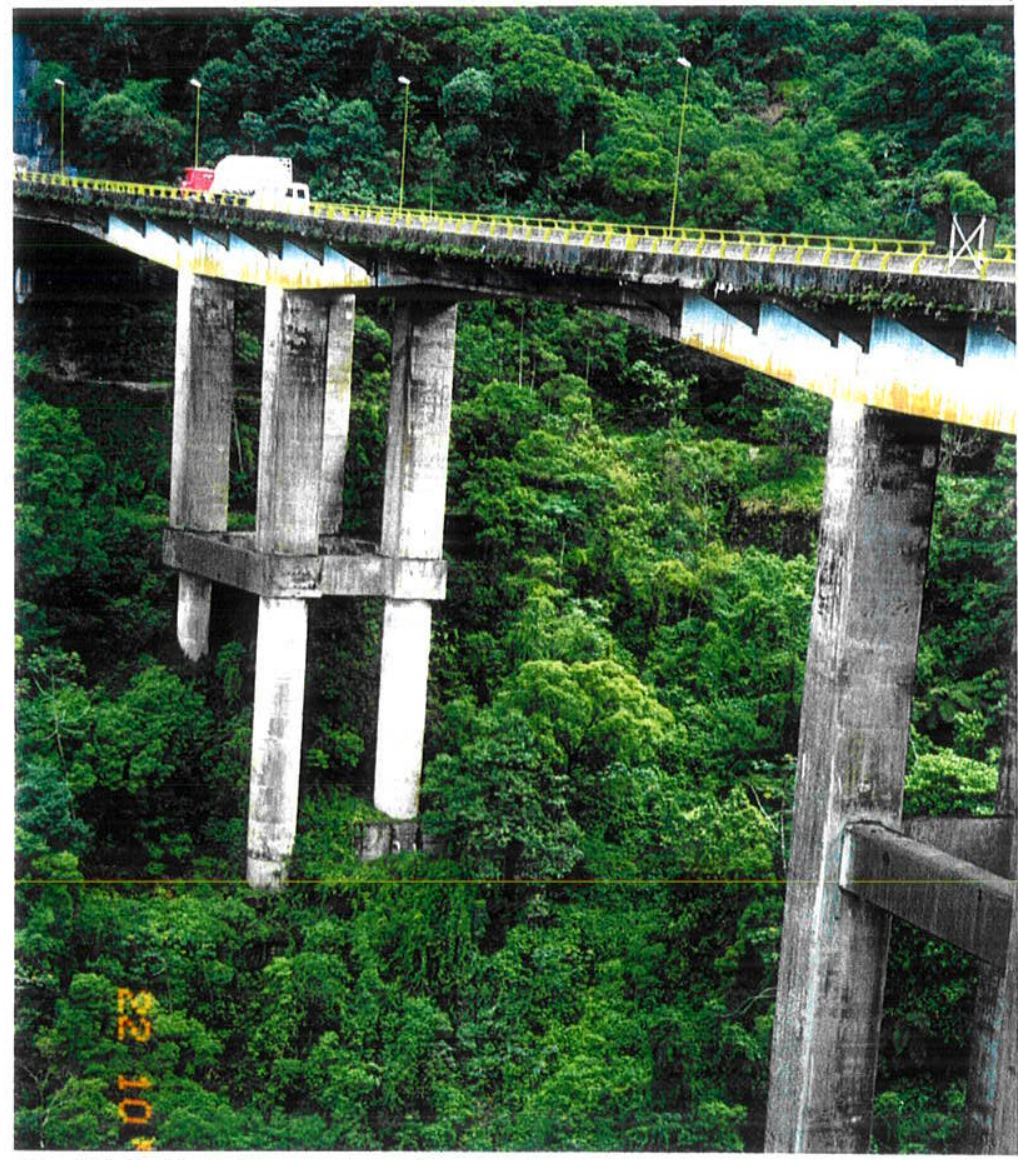

Fotografia V.2.4. Aspecto da vegetação no mesmo local em Out/1999. 


\section{CAPÍtulo VI}

\section{ASPECTOS CONCEITUAIS DA ESTABILIDADE DE ENCOSTAS}

\section{VI.1. MOVIMENTOS DE ENCOSTAS - CLASSIFICAÇÃO E FATORES INTERVENIENTES}

Os movimentos e instabilizações em encostas são condicionados por uma série muito grande de fatores, cujas origens estão na formação da própria rocha e que se desenvolvem à medida que ela vai sofrendo transformações no decorrer do tempo, até ocorrer a deflagração efetiva do processo de movimentação.

A maior parte desses fatores pode ser englobada no que chamamos de condicionantes geológicos, geomorfológicos e estruturais, bem como no clima (destacando a pluviometria) e na vegetação, conforme abordamos nos capítulos anteriores. Além disso, devemos levar em conta a influência decisiva da ação antrópica na deflagração dos processos instabilizatórios, sempre que ela se faz presente.

Dentre as várias classificações existentes para os movimentos de encostas, preferimos apresentar a de VARNES, 1978, conforme consta na Tabela VI.1.1.

Nessa tabela, o termo solo é empregado conforme o uso corrente em engenharia, correspondendo aos materiais incoerentes $e$ inconsolidados, sejam areias, siltes ou argilas.

As quedas, referem-se principalmente a eventos ocasionais localizados. Em áreas com matacões (não típicas da Serra do Cubatão), os mesmos vão sendo desconfinados pela ação hidráulica e podem vir a rolar encosta abaixo pela ação da gravidade.

Tombamentos, são fenômenos que ocorrem em condições de juntas paralelas à crista do talude, mergulhando para dentro do maciço e que tendem a se deslocar segundo sua linha de maior declive.

Os escorregamentos, são os movimentos mais visiveis na Serra do Mar, estando classificados basicamente em rotacionais e translacionais. A ruptura rotacional é a regra nos solos mais homogêneos, como os horizontes coluviais que constituem a maioria dos escorregamentos cíclicos dos períodos chuvosos. Após rompido, esse material se desloca longas distâncias encostas abaixo, transformando-se em corridas de lama e deixando extensas cicatrizes lineares na paisagem. 
Os escoamentos de massa tipo rastejo, são muito comuns em horizontes superficiais, como os já referidos solos coluviais, provocando um curioso encurvamento nos caules vegetais, que adquirem um perfil de "Gogó de Ema", provocado pelo seu deslocamento gradual e lento no sentido do movimento encosta abaixo, ao mesmo tempo que vão crescendo obedecendo ao fototropismo positivo que tende a verticalizá-los.

Quanto ao rastejo profundo, que não tem sido tão bem estudado, é na verdade de grande importância na estabilidade geral da Serra do Mar, pois afeta os horizontes rochosos mais profundos, até dezenas de metros de profundidade, provocando a abertura de fendas de tração e estabelecendo um comportamento mecânico que o Prof. Manuel Rocha do LNEC, chamou de "maciço desarticulado", em 1973, ao visitar as obras da Rodovia dos Imigrantes. Esse comportamento, explica a ocorrência de uma drenagem subterrânea predominantemente vertical nessas encostas, com elevada permeabilidade hidráulica. Pudemos constatar inclusive, durante as escavações de tubulões de viadutos dessa rodovia (Viadutos 12 e 13), que fendas decimétricas ocorriam até pelo menos $20 \mathrm{~m}$ de profundidade, permitindo comunicação verbal entre trabalhadores escavando tubulões próximos.

$\mathrm{O}$ rastejo é tambem característico das formações de tálus, ocorrendo tanto superficialmente como em profundidade. Geralmente o movimento é intermitente, acompanhando os períodos chuvosos, variando de velocidade de ponto para ponto, tanto horizontalmente como verticalmente (normalmente é maior junto à superfície, diminuindo com a profundidade). Com a saturação, o movimento tende a se acelerar, à medida que diminue a resistência ao cizalhamento do material, podendo ocorrer a ruptura do tálus, com escorregamento por vezes catastrófico, como exemplificaremos em outro capítulo.

A Tabela VI.1.2., apresenta alguns dos principais fatores deflagradores dos movimentos de encostas.

A remoção de solos, como fator deflagrador de movimentos, pode ser exemplificada pelos cortes em encostas de solo, conforme conhecemos tão bem em certos trechos de rodovias antigas como o Caminho do Mar e a própria Via Anchieta, ou nas estradas de serviço da Rodovia dos Imigrantes. É comum tambem, ocorrer a remobilização de um escorregamento, pela remoção descuidada do material no sopé do mesmo e que está funcionando como resistência passiva ao movimento (prática utilizada por algumas prefeituras e empreiteiras pouco qualificadas). 
Tabela VI.1.1. Classificaçáo dos movimentos de encostas (Varnes, 1978)

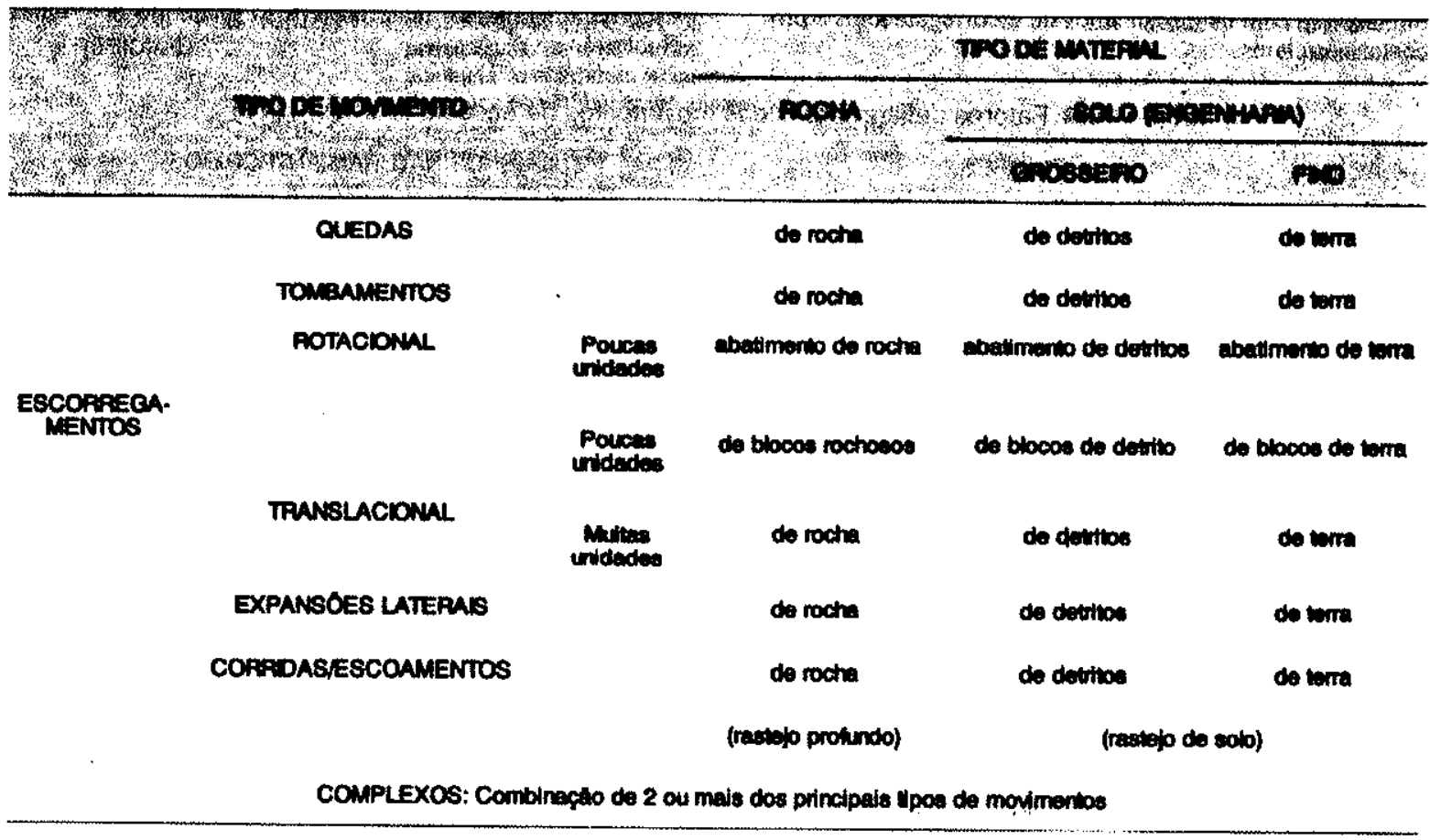

Tabela VI.1.2. Fatores deflagradores dos movimentos de encostas (Varnes, 1978)

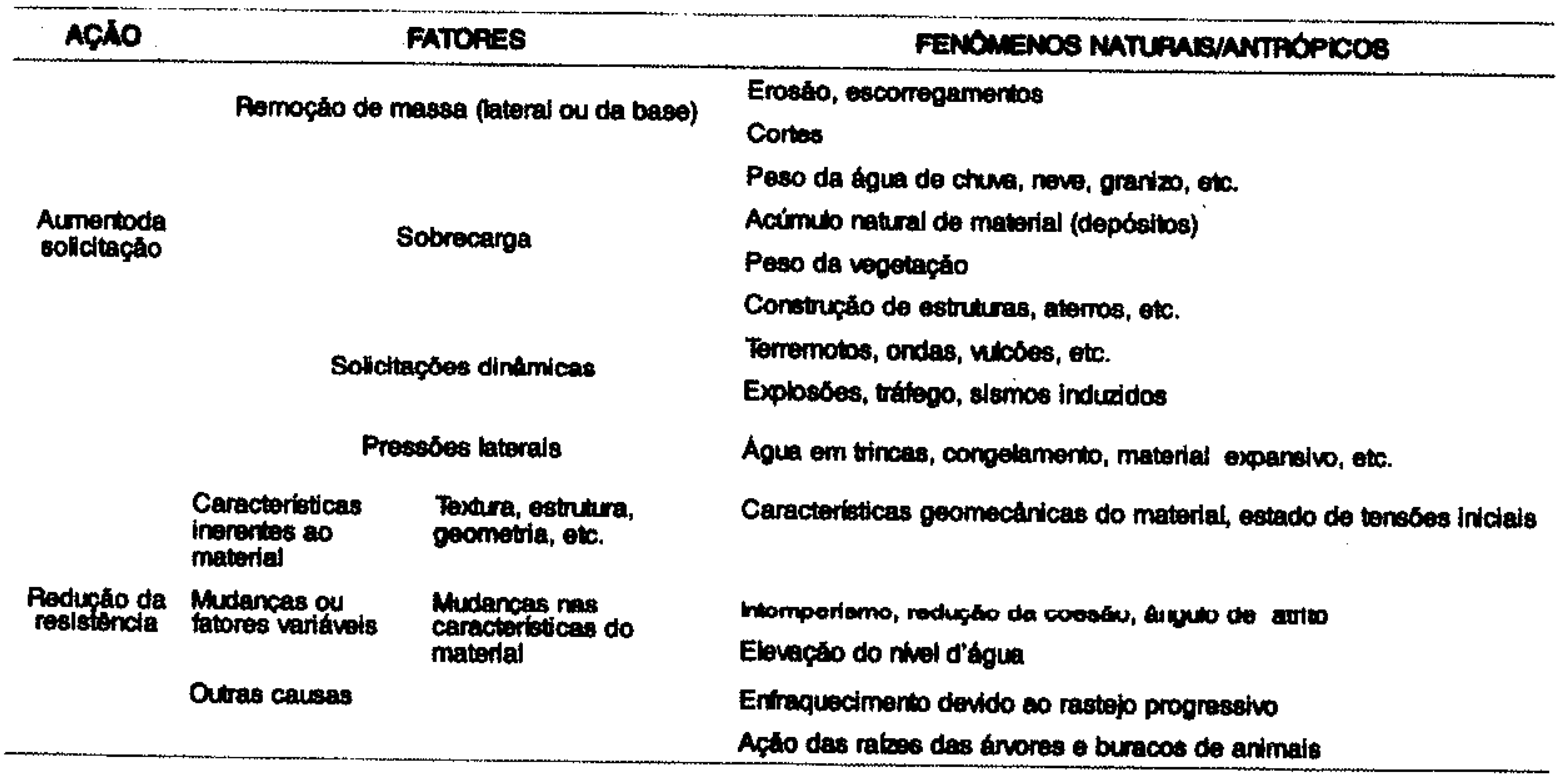


Sobrecargas, podem ser aterros em encostas causando a ocorrência de rupturas de base, exemplos que tambem fazem parte da história das construções rodoviárias em trechos da Serra do Mar. O termo sobrecarga, na tabela é empregado de forma ampla, englobando inclusive toda a massa da vegetação. Já o "efeito alavanca" (oscilação das árvores com os ventos, transmitida ao terreno por suas raízes), está colocado em "outras causas".

Evidentemente, a água e os mecanismos dela resultantes, preponderam nos fatores predisponentes e tambem nos fatores deflagradores dos movimentos em encostas, se deixarmos de lado a ação antrópica.

No caso dos maciços de solos, sabemos que os parâmetros determinantes da resistência ao cisalhamento são o ângulo de atrito interno e a coesão.

A coesão possui uma parcela relacionada à capilaridade, denominada "coesão aparente", que varia com o grau de saturação do solo e essa variação pode ter grande influência no mecanismo de escorregamento.

É o que ocorre na Serra do Mar, onde a maioria dos escorregamentos cíclicos afetam o solo coluvionar (ou coluvial). A variação da coesão aparente desses solos em função do grau de saturação, foi estudada por CARVALHO, 1991 (Figura VI.1.1.).

$\mathrm{Na}$ figura, podemos observar como é significativo o efeito da saturação $\mathrm{S}$, sobre a variação da coesão aparente $\mathrm{c}$. A curva de correlação, mostra que com o aumento do grau de saturação de $60 \%$ para $100 \%$, a coesão aparente diminue de $20 \mathrm{kPa}$ para praticamente zero.

Outras características e propriedades dos solos, podem afetar sua susceptibilidade aos processos de instabilização, devendo ser consideradas na análise de casos específicos. É o caso de estruturas reliquiares em solos residuais (incluindo os solos saprolíticos da Serra do Mar), que podem ter grande influência na sua resistência ao cisalhamento e que portanto devem ser consideradas numa analise de estabilidade de taludes nesse material.

Para exemplificar a influência dessas estruturas reliquiares (tambem chamadas de macroestruturas de solos por alguns autores), apresentamos a Tabela VI.1.3.

Os valores de ângulo de atrito interno e coesão, foram obtidos em ensaios de cisalhamento direto de 4 tipos de solos residuais, mostrando significativa variação, dependendo da direção do esforço aplicado, em relação à posição do plano da macroestrutura existente (laminada, xistosa, ou bandada). 


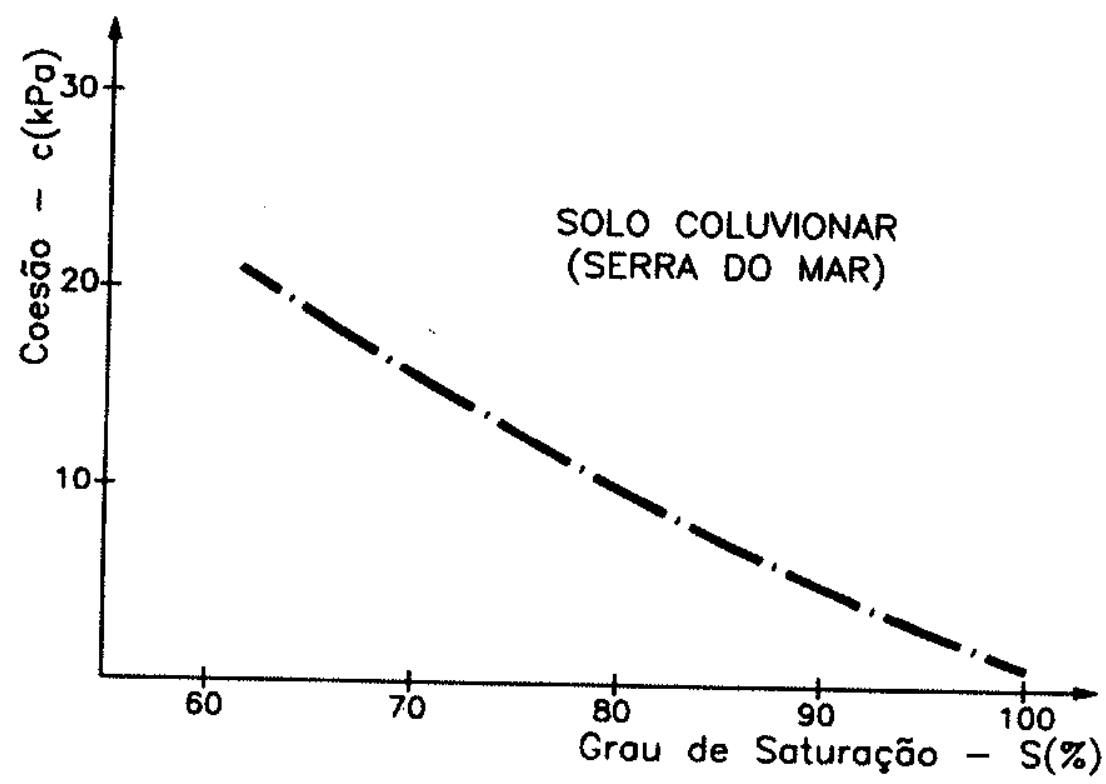

Figura VI.1.1. Variação da coesão aparente do solo coluvionar da Serra do Mar em função do grau de saturação (Carvalho, 1991)

Tabela VI.1.3. Resistência de solos com macroestruturas (Sandroni, 1985)

\begin{tabular}{|c|c|c|c|c|}
\hline \multirow{2}{*}{ SOLO RESDUAL. } & \multirow{2}{*}{$\begin{array}{c}\text { MACRO } \\
\text { ESTRUTURA }\end{array}$} & \multicolumn{2}{|c|}{ CISALHAMENTO DIRETO ( $50 \mathrm{kPa} \times 0<500 \mathrm{kPa})$} & \multirow{2}{*}{$\begin{array}{c}\text { CONDLCOES DE } \\
\text { UMBADE }\end{array}$} \\
\hline & & PARALELO * & PERPENDICULAR * & \\
\hline Quartito & Laminada & $\begin{array}{c}C^{\prime}=20 \mathrm{kPa} \\
\varphi^{\prime}=37^{\circ}\end{array}$ & $\begin{array}{c}c^{\prime}=50 \mathrm{kPa} \\
\varphi^{\prime}=44^{\circ}\end{array}$ & Umido \\
\hline Quartzito micáceo & Xistosa & $\begin{array}{c}c^{\prime}=40 \mathrm{kPa} \\
\varphi^{4}=22^{\circ}\end{array}$ & $\begin{array}{c}c^{+}=45 \mathrm{kPa} \\
\varphi^{4}=27^{\circ}\end{array}$ & Úmido \\
\hline Gnaisse migmatizado & Bandada & $\begin{array}{c}c^{\prime}=40 \mathrm{kPa} \\
\varphi^{+}=20^{\circ}\end{array}$ & $\begin{array}{c}C^{\prime}=52 \mathrm{kPa} \\
\varphi^{\prime}=23^{\circ}\end{array}$ & Úmido \\
\hline Gnalise migmatizado & Bandada & $\begin{array}{c}c^{\prime}=30 \mathrm{kPa} \\
\varphi^{\prime}=21^{\circ}\end{array}$ & $\begin{array}{c}c^{\prime}=49 \mathrm{kPa} \\
\varphi^{\prime}=22^{\circ}\end{array}$ & Saturado \\
\hline
\end{tabular}


Os valores máximos da tabela, como se pode observar, foram obtidos para esforços aplicados normalmente aos planos das macroestruturas dos solos e os valores mínimos para os esforços aplicados paralelamente a essas estruturas.

Para maciços rochosos, além dos parâmetros básicos de resistência ao cisalhamento é fundamental considerarmos a ocorrência das descontinuidades presentes e como elas influenciam essa resistência.

Uma vez que os valores de ângulo de atrito interno e coesão são mais elevados para as rochas que para os solos delas resultantes e os solos em geral, considerados apenas esses parâmetros, os taludes rochosos deveriam ser sempre mais estáveis, admitindo comparativamente maior inclinação que os taludes em solos.

Ocorre porém, que essa afirmação muitas vezes não é verdadeira, pois em taludes rochosos as rupturas são condicionadas principalmente pela ocorrência de planos de juntas, os quais devem ser cuidadosamente analisados.

A ocorrência de juntas, diminue a resistência ao cisalhamento dos maciços rochosos, atuando no sentido da diminuição do seu ângulo de atrito, conforme mostrado na Tabela VI.1.4.

Observamos na tabela que, alem da diferença de valores do ângulo de atrito para cada tipo de rocha, existe significativa variação para uma mesma rocha em função da condição considerada. Rochas intactas, tem ângulo de atrito geralmente superior a $45^{\circ}$ (condição conhecida como "resistência de pico"), diminuindo esse valor cerca de $20 \%$ a $25 \%$ pela simples existência de juntas e, caindo ainda mais, quando ocorre início de cisalhamento, permanecendo porem um certo valor mínimo, conhecido por "atrito residual".

Encostas que apresentam juntas com indícios de movimentação (cisalhadas), devem portanto serem consideradas na condição de ruptura iminente. 
Tabela VI.1.4. Valores de ângulo de atrito para rochas intactas, com juntas e com juntas cizalhadas (Hoek, 1972)

\begin{tabular}{|c|c|c|c|}
\hline \multirow[t]{2}{*}{ TPO DE ROCHA } & \multicolumn{3}{|c|}{ ÃNGULO DE ATRITO ( ) } \\
\hline & NTACTA & JUNTA & RESDUAL \\
\hline Andesito & 45 & $31-35$ & $28-30$ \\
\hline Basalto & $48-50$ & 47 & - \\
\hline Gesso & $\cdot$ & $35-41$ & - \\
\hline Diorito & $53-55$ & - & - \\
\hline Granito & $50-64$ & - & $31-33$ \\
\hline Grauvaca & $45-50$ & - & - \\
\hline Calcário & $30-60$ & . & $33-37$ \\
\hline Morrzonito & $48-65$ & $\cdots$ & $28-32$ \\
\hline Pórfiro & - & 40 & $30-34$ \\
\hline Quartzito & 64 & 44 & $26-34$ \\
\hline Arenito & $45-50$ & $27-38$ & $25-34$ \\
\hline Xisto & $26-70$ & - & - \\
\hline Folhelho & $45-64$ & 37 & $27-32$ \\
\hline Siltito & 50 & 43 & - \\
\hline Ardósia & $45-60$ & - & $24-34$ \\
\hline
\end{tabular}




\section{Vl.2. TIPOS DE RUPTURA}

Em solo coesivo, o tipo de ruptura padrão está esquematizado na Figura VI.2.1. Trata-se de superfície de ruptura circular, onde $\mathrm{O}$ e $\mathrm{r}$ representam respectivamente $\mathrm{O}$ eixo $e \circ$ raio do cilíndro deslizante teórico e $\zeta_{R}$ representa a resistência ao cisalhamento do maciço.

A figura é genérica para solos coesivos, variando para cada caso o raio de curvatura da superfície cizalhante e sua posição em relação à face do talude.

Os solos argilosos tem coesão maior que os solos arenosos. A coesão passa a diminuir quanto mais arenoso o solo se torna, tendendo a zero para as areias eólicas arredondadas (areias de dunas). À medida que a coesão diminue, o raio de curvatura da superfície de ruptura aumenta, tendendo à ruptura plana.

No caso de solos com macroestruturas, como os saprolíticos (com estruturas reliquiares tipo bandamentos, xistosidades, etc.), elas atuam como planos de fraqueza, podendo ocorrer rupturas planas, ou segundo um padrão composto circular-plano.

As rupturas circulares são objeto de estudo específico da Mecânica de Solos e não serão detalhadas neste trabalho.

Convem entretanto citar que, no caso dos solos coluviais que sofrem escorregamentos periódicos na Serra do Mar, as rupturas são inicialmente circulares, até encontrarem o substrato residual, ocorrendo então deslizamento planar.

Para maciços rochosos, a influência das descontinuidades é preponderante nos mecanismos de ruptura, pois constituem planos de menor resistência ao cisalhamento. Alguns tipos de ruptura plana são apresentados na Figura VI.2.2.

Verifica-se que, quando existe no maciço mais de uma família de descontinuidades, a ruptura é condicionada por ambas, resultando num padrão composto.

$\mathrm{Na}$ Figura VI.2.3., estão representados alguns dos principais tipos de ruptura plana em taludes rochosos e suas correspondentes projeções em estereogramas, associadas às condições estruturais. Em cada estereograma, estão representados os polos dos planos de juntas, o plano médio das juntas, o plano da face do talude e a linha de crista do talude. 


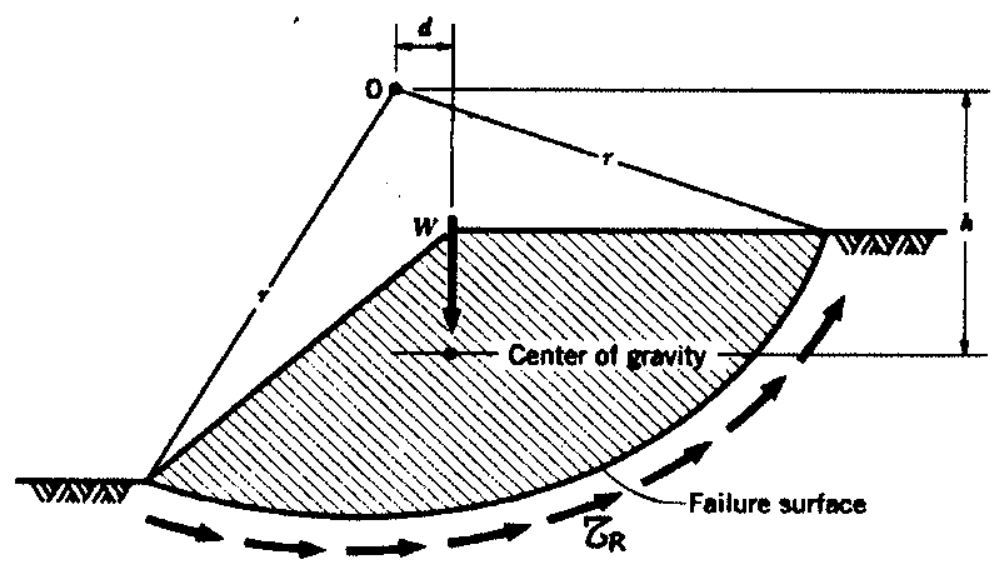

Figura VI.2.1. Ruptura em solo coesivo (Cernica, 1994)

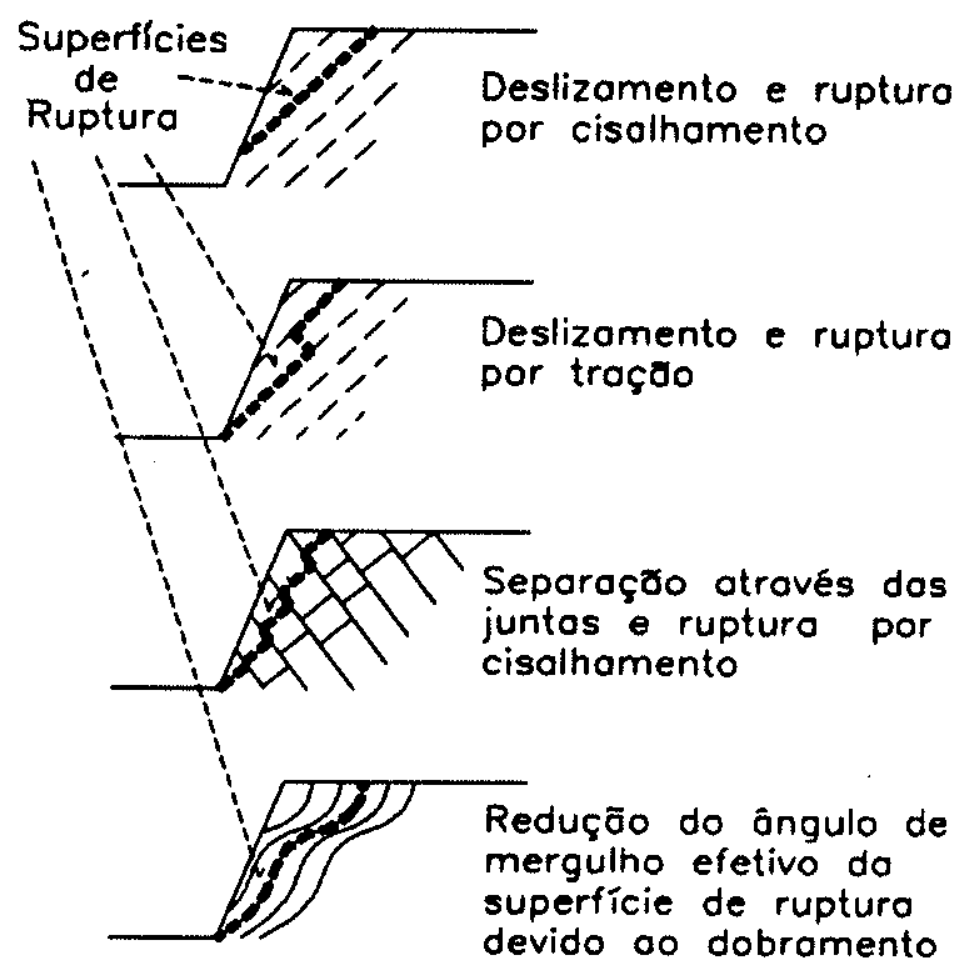

Figura VI.2.2. Tipos de ruptura plana (Piteau e Martin, 1991) 


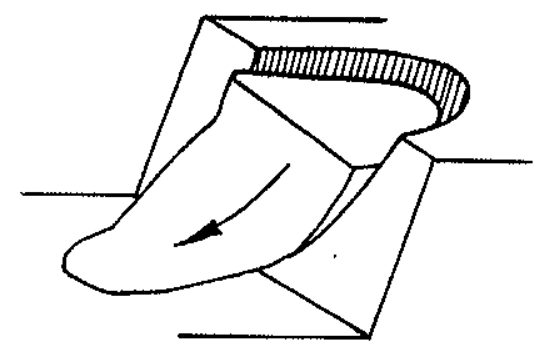

a. Circular fallure in overburden soil waste rock or heavlly fractured rock with no identiflable structural pattern.

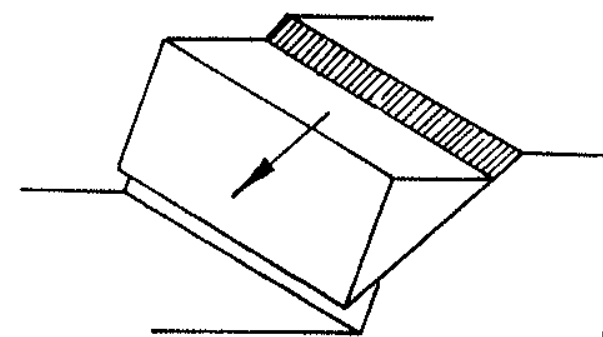

b. Plane failure in rock with highly ordered structure such as slate.

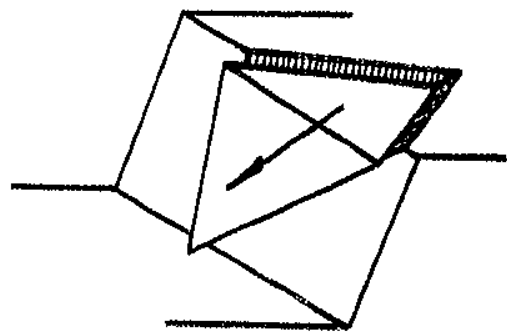

c. Wede follupe on two interrecting discontinultios.

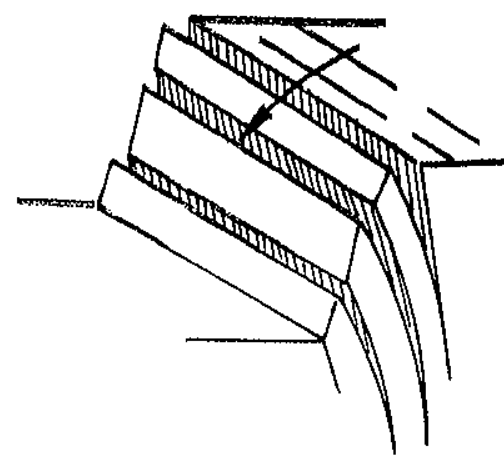

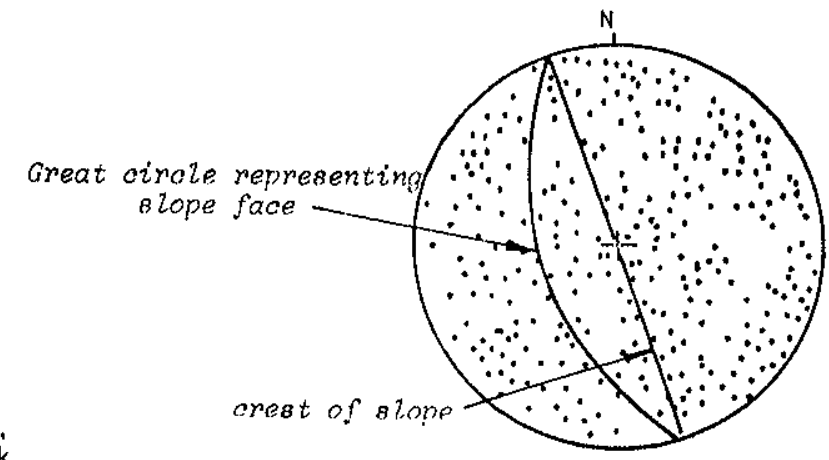

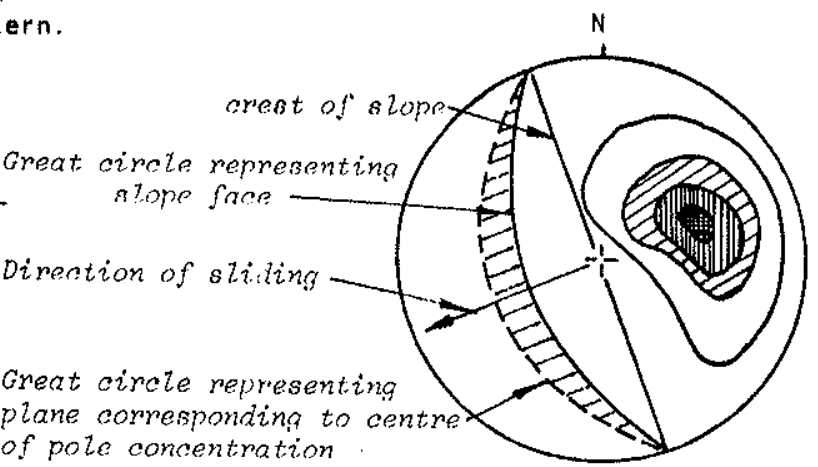

of pole concentration
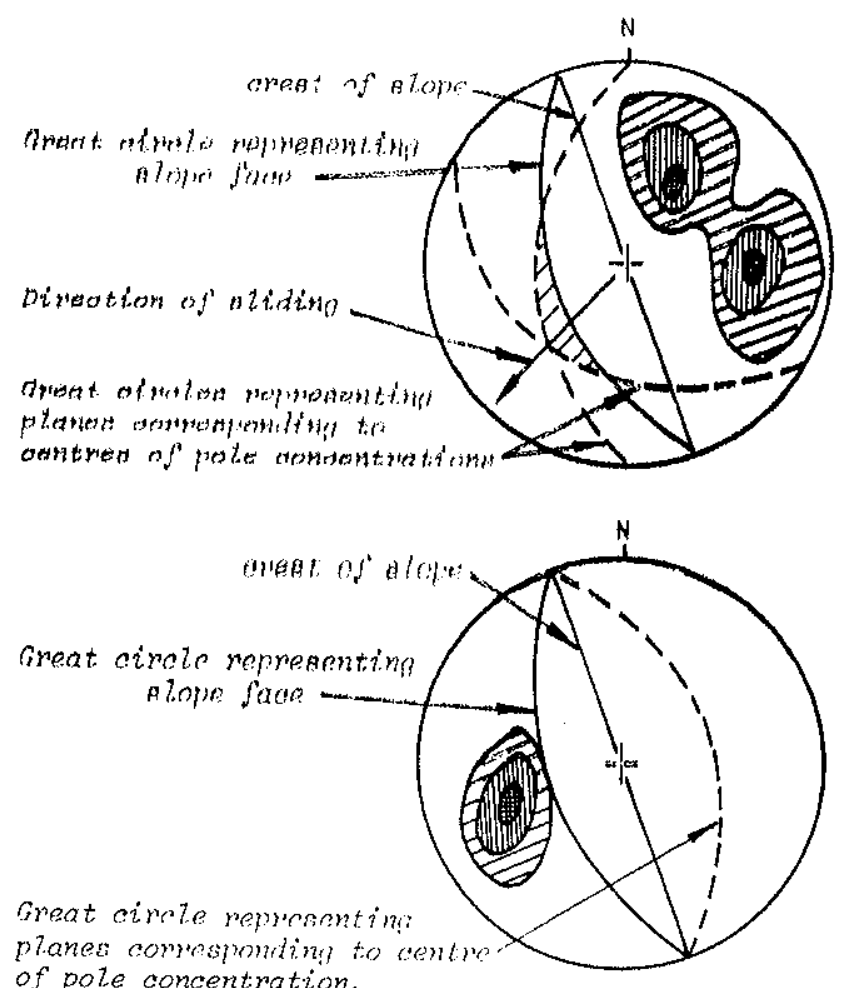

d. Toppling failure in hard rock which can form columnar structure separated by steeply dipping discontinuities.

Figura VI.2.3. Principais tipos de rupturas em taludes rochosos e suas condições estruturais representadas em estereogramas (Hoek \& Bray, 1997) 
Observamos na figura anterior, que o tipo a é característico de rocha branda ou rocha muito fraturada sem padrão definido das descontinuidades, de tal modo que os polos das juntas aparecem com distribuição homogênea no estereograma. Esse tipo de ruptura circular é tambem característico de solo coesivo.

$\mathrm{O}$ tipo b, apresenta uma única família de juntas de direção paralela à direção do talude e ângulo de mergulho menor que o dele. A zona achurada no estereograma, representa a condição de estabilidade mais desfavorável, que podemos tambem chamar de "condição de ruptura".

No tipo c, existem duas famílias de juntas que cortam o talude formando uma cunha de ruptura. As intersecções dos planos dessas juntas com o plano do talude, representados no estereograma, definem a zona de ruptura (achurada).

O tipo d, ilustra uma única família de juntas, de direção paralela à direção do talude e com ângulo de mergulho superior ao do talude. É a condição potencial de ruptura por tombamento, representada no estereograma pelos planos das juntas $e$ do talude, em semicírculos opostos.

Casos mais complexos, podem ser entendidos pela combinação de mais de um dos tipos esquematizados. 


\section{3. CLASSIFICAÇÕES GEOMECÂNICAS}

Foram elaboradas diversas classificações geomecânicas, por vários autores, a partir especialmente da década de 1940. Essas classificações foram preparadas visando aplicações em obras subterrâneas, mas com o passar dos anos, foram sendo estendidas e adaptadas para uso tambem em obras de superfície.

Algumas das principais classificações estão apresentadas na Tabela VI.3.1., com observações concernentes ao seu uso na época e posteriores modificações.

Os vários autores, em suas classificações, basearam-se em alguns índices característicos das rochas, conforme consta da Tabela VI.3.2..

Os autores que utilizaram o maior número de índices, como se pode ver, foram Wickham, Beniawski e Barton. Entretanto, Wickham não considerou o RQD, nem fez recomendações executivas, o que na prática restringe a sua aplicação.

O parâmetro RQD ("Rock Quality Designation"), proposto por DEERE et al (1967) é um índice de qualidade do maciço rochoso, com valor em porcentagem, obtido em testemunhos de sondagem. É definido pela relação entre o comprimento da amostra recuperada numa manobra (soma das peças maiores que $10 \mathrm{~cm}$ ) e o comprimento efetivamente perfurado.

BENIAWSKI, 1973, introduziu o Sistema RMR ("Rock Mass Rating System"), o qual sofreu posteriormente diversas modificações. Em 1979, o autor propôs uma versão da sua classificação ao "South African Council for Scientific and Industrial Research - CSIR"), cuja versão traduzida é apresentada na Tabela VI.3.3.. Essa classificação tambem é conhecida como CSIR - Classificação geomecânica para maciços fraturados.

Conforme se observa nessa classificação, para cada característica considerada $e$ faixa de variação, a rocha recebe uma nota (peso relativo). A soma dessas notas ou pesos relativos, resultará num valor numérico final para o conjunto, estabelecendo a classificação geomecânica do maciço numa das seguintes categorias:

Classse I - 100 a 81 - muito bom

Classe II - 80 a 61 - bom

Classe II - 60 a 41 - regular

Classe IV - 40 a 21 - pobre

Classe $\mathrm{V}-\leq 20$ - muito pobre

Para cada classe é estimado um tempo médio de auto-sustentação do maciço, o qual varia desde anos até minutos, em função do vão livre considerado para a seção da escavação. 
Tabela VI.3.1. Principais classificações geomecânicas (Beniawski, 1989)

\begin{tabular}{|c|c|c|c|c|}
\hline CLASSIFICAÇĀO & AUTOR E DATA & ORIGEM & $\begin{array}{l}\text { APLICACYOSS } \\
\text { OHIGNAIS }\end{array}$ & $\begin{array}{l}\text { OBSERVACÓES } \\
\end{array}$ \\
\hline Carga de rocha & $\begin{array}{l}\text { Teraghi } \\
\text { (1946) }\end{array}$ & $\overline{E U A}$ & $\begin{array}{l}\text { Túneis com } \\
\text { suportes } \\
\text { metálicos }\end{array}$ & $\begin{array}{l}\text { Amplo emprego nos EUA por } 40 \text { anos; Inadequada para os } \\
\text { métodos modernos de execuçáo de tunels (ancoragens } \theta \text {. } \\
\text { concreto projetado); }\end{array}$ \\
\hline $\begin{array}{l}\text { Tempo de auto- } \\
\text { sustentação }\end{array}$ & $\begin{array}{l}\text { Laufter } \\
\text { (1958) }\end{array}$ & Austria & Tứneis & $\begin{array}{l}\text { Introduziu o conceito de vãos livres sem suporte e seu tempo } \\
\text { de auto-sustentaçāo, em funçáo da qualidade do maciço; multo } \\
\text { consenadora para aplicação nos métodos; }\end{array}$ \\
\hline RQD & $\begin{array}{l}\text { Deere et al. } \\
(1967)\end{array}$ & EUA & $\begin{array}{l}\text { Descriçāo de } \\
\text { testemunhos e } \\
\text { túneis }\end{array}$ & $\begin{array}{l}\text { Simples descrição das condiçóes de um testemunho de } \\
\text { sondagem rotativa; parte integrante dos sistemas modernos de } \\
\text { classificaçāo; náo considera condiçáo de supenficie de juntas e } \\
\text { materiais de preenchimento; muito sensivel aos efeitos de } \\
\text { orientaçáo dos testemurhos; }\end{array}$ \\
\hline RSR & $\begin{array}{l}\text { Wickham et al. } \\
(\$ 972)\end{array}$ & EUA & $\begin{array}{l}\text { Túneis com } \\
\text { suportes } \\
\text { metálicos }\end{array}$ & $\begin{array}{l}\text { Introduziu as avaliaçōes numéricas "ratings" e ponderaçōes } \\
\text { para correlecionar a qualidade do maciço com dimensóes das } \\
\text { escavaçōes e suportes necessários; base para os sistemas } \\
\text { subseqüentes mais empregados do nivel Internaclonal; }\end{array}$ \\
\hline Sistema RMR & $\begin{array}{l}\text { Bieniawski } \\
(1973)\end{array}$ & $\begin{array}{l}\text { Africa } \\
\text { do Sul }\end{array}$ & Túneis e minas & $\begin{array}{l}\text { Evolução dos sistemas anteriores; amplamente atterado em } \\
\text { relaçáo à versăo original (1974, 1975, 1976, 1979, 1984); } \\
\text { deservolvido com base em } 49 \text { casos históricos. Versão } \\
\text { atualizada conta com } 268 \text { casos reais (Bieniawski, 1989); }\end{array}$ \\
\hline Sistema Q & $\begin{array}{l}\text { Barton et al. } \\
(1974)\end{array}$ & Noruega & $\begin{array}{l}\text { Túneis e } \\
\text { cavidades amplas }\end{array}$ & $\begin{array}{l}\text { Baseado no método do RQD; introduçáo de quatro parámetros } \\
\text { adicionais: número e condição das juntas, condição de água } \\
\text { subterránea, tensóes nas vizinhanças da escavação; } \\
\text { desemolvido com base em mais de } 200 \text { casos reais; }\end{array}$ \\
\hline
\end{tabular}

Tabela VI.3.2. Indices característicos das principais classificações geomecânicas (ABGE, 1998)

\begin{tabular}{|c|c|c|c|c|c|c|}
\hline INDICES CARACTERISTKCOS & $\begin{array}{c}\text { Terzaghi } \\
(1946)\end{array}$ & $\begin{array}{l}\text { Lauffer } \\
(1958) \\
\end{array}$ & $\begin{array}{l}\text { Deere et al. } \\
(1967)\end{array}$ & $\begin{array}{l}\text { Wickham et al. } \\
\text { (1974) }\end{array}$ & $\begin{array}{l}\text { Bieniawski } \\
\text { (1973) }\end{array}$ & $\begin{array}{l}\text { Barton et al. } \\
(1974)\end{array}$ \\
\hline \multicolumn{7}{|c|}{$\begin{array}{llll}(1900 & (1974) & (1973) & (1974) \\
\end{array}$} \\
\hline - tipo litológico & & & & $x$ & & \\
\hline - estrutura & $x$ & $x$ & & $x$ & & \\
\hline - grau de alteração & $x$ & $x$ & & $x$ & & $x$ \\
\hline - minerais expansivos & $x$ & $x$ & $\mathrm{x}$ & & & $x$ \\
\hline - resistência & & $x$ & & $x$ & $x$ & $x$ \\
\hline \multicolumn{7}{|l|}{ H- Descontinuidades } \\
\hline - orientação & & & & $x$ & $x$ & \\
\hline - espaçamento & $x$ & $x$ & $x$ & $x$ & $x$ & $x$ \\
\hline - rugosidade das paredes & & & & & $x$ & $x$ \\
\hline - atteração das paredes & & & & $x$ & $x$ & $x$ \\
\hline - abertura & & & & $\mathrm{x}$ & $\mathrm{x}$ & $x$ \\
\hline - preenchimento & & & . & & $x$ & $x$ \\
\hline - número de familias & & & & & & $\hat{x}$ \\
\hline \multicolumn{7}{|l|}{ III - Maciço rochoso } \\
\hline - RQD & & & $x$ & & $\mathrm{x}$ & $x$ \\
\hline \multicolumn{7}{|l|}{ - velocidade de ondas elásticas } \\
\hline - água & $x$ & $x$ & & $x$ & $x$ & $x$ \\
\hline - tensōes "in situ" & $x$ & $x$ & $x$ & & & $x$ \\
\hline \multicolumn{7}{|l|}{ N-Métodos construtivos } \\
\hline (recomendações de procedimento) & $\operatorname{sim}$ & não & $\operatorname{sim}$ & กล̃o & $\operatorname{sim}$ & $\operatorname{sim}$ \\
\hline Número total de indices & 6 & 7 & 4 & 9 & 9 & 12 \\
\hline indices relativos a descontinuidades & 1 & 1 & 1 & 4 & 6 & 6 \\
\hline
\end{tabular}


Tabela V1.3.3. Sistema RMR de classificação geomecânica (Beniawski, 1979)

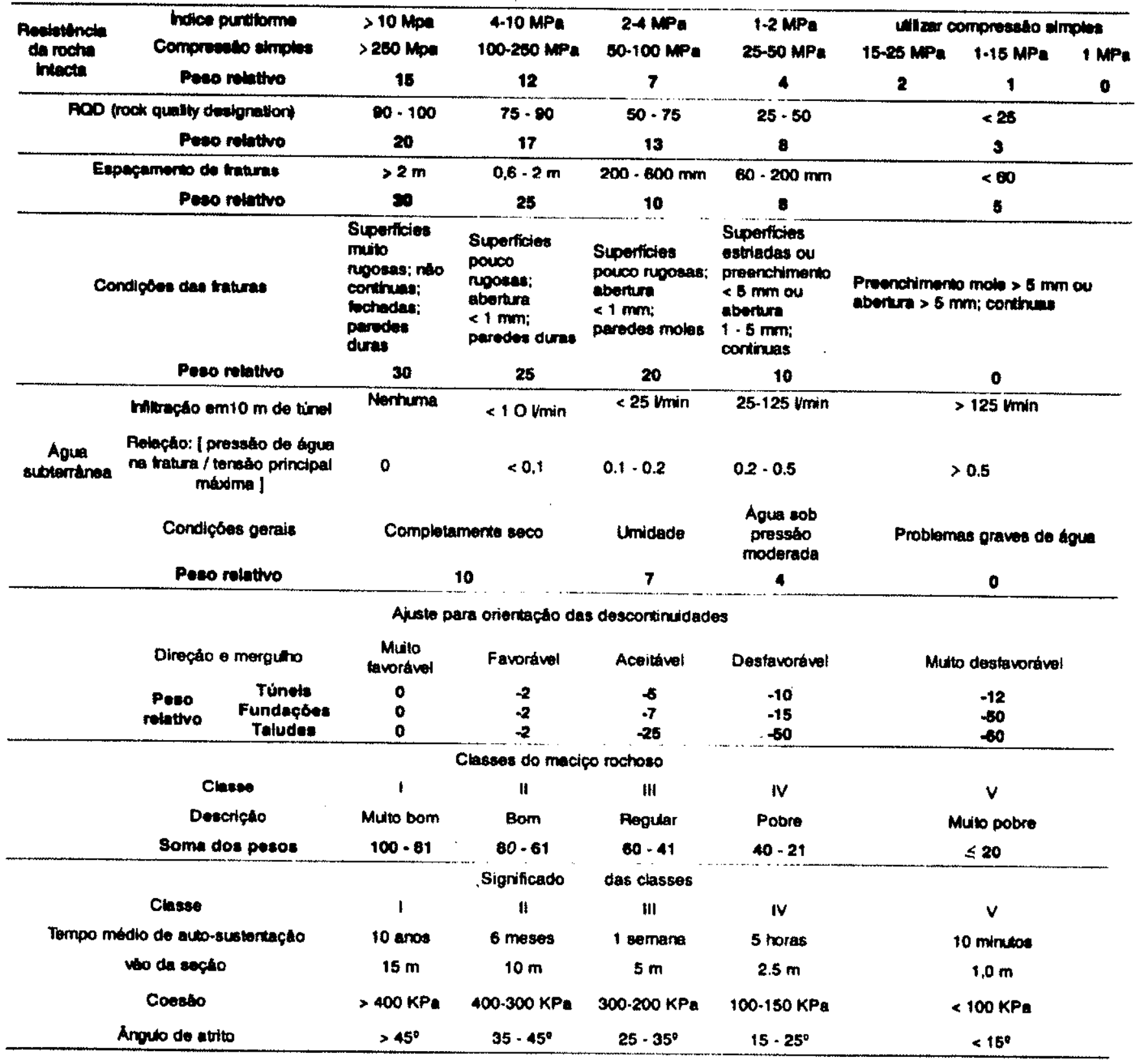


Convem lembrar que nas tabelas de Beniawski, podem-se encontrar variações nas faixas atribuidas a determinados índices e seus pesos relativos, dependendo do ano da adaptação ou versão utilizada.

BARTON et al (1974), estudando quase 2 centenas de casos histórico de túneis e escavações subterrâneas, propuseram ao "Norwegian Geotechnical Institute - NGI", um índice de qualidade do maciço rochoso, denominado índice $Q$, para caracterizar sua condição geral de estabilidade quando submetido à escavação.

$O$ índice Q é definido pela seguinte expressão:

Onde:

$$
\mathrm{Q}=(\mathrm{RQD} / \mathrm{Jn}) \times(\mathrm{Jr} / \mathrm{Ja}) \times(\mathrm{Jw} / \mathrm{SRF})
$$

\begin{tabular}{|c|c|}
\hline ock quality designation) & $\begin{array}{l}=\text { índice de qualidade da rocha, } \\
\text { proposto por DEERE }\end{array}$ \\
\hline Jn (joint set number) & $\begin{aligned}= & \text { indice de influência do número } \\
& \text { de famílias de juntas }\end{aligned}$ \\
\hline $\mathrm{Jr}$ (joint roughness number) & $\begin{array}{l}=\text { índice de influênciam da } \\
\text { rugosidade das paredes das } \\
\text { juntas }\end{array}$ \\
\hline Ja (joint alteration number) & $\begin{array}{l}=\text { índice de influência da alteração } \\
\text { das paredes das juntas }\end{array}$ \\
\hline joint water reduction fact & $\begin{array}{l}=\text { índice de redução da resistência } \\
\text { pela presença de água }\end{array}$ \\
\hline SRF (stress reduction factor) & $\begin{array}{l}=\text { índice de influência das tensões no } \\
\text { entorno da escavação }\end{array}$ \\
\hline
\end{tabular}

Verifica-se na expressão a grande importância atribuida às condições das descontinuidades ou juntas, alem do estado de tensões na região circundante à excavação. Os valores dos diversos parâmetros que entram na expressão acima do cálculo de $\mathrm{Q}$, devem ser individualmente determinados de acordo com a Tabela VI.3.4., apresentada nas três partes $\underline{\mathrm{a}}, \underline{\mathrm{b}}$ e $\underline{\mathrm{c}}$. A tabela, bastante detalhada, facilita a obtenção desses valores, trazendo no final considerações adicionais para sua correta interpretação. 
Tabela V1.3.4. Parâmetros rochosos utilizados na obtenção do índice Q da classificação NGI (Barton et al, 1974)

\begin{tabular}{|c|c|c|}
\hline Deacription & value & Notes \\
\hline $\begin{array}{l}\text { 1. ROCK QUALITY DEsighayion } \\
\text { A. Very poor } \\
\text { A. Ponr } \\
\text { C. Fair } \\
\text { D. Good } \\
\text { E. Excellient }\end{array}$ & $\begin{array}{c}\text { RQD } \\
0-25 \\
75-50 \\
50-75 \\
75=90 \\
90-100\end{array}$ & $\begin{array}{l}\text { 1. Where RQD is reported or measured as } \\
\leq 10 \text { including } 0 \text { ) a a nom nal value } \\
\text { of to is used to evaiuate } Q \text {. } \\
\text { 2. RQD intervals of } 5 \text {, i.e. 100, } 95,90 \text { ete } \\
\text { ore sufficiently accurace. }\end{array}$ \\
\hline $\begin{array}{l}\text { 2. JOINT SET NUnBER } \\
\text { A. Massive, no or few joints } \\
\text { a. One joint set } \\
\text { c. One joint set plus random } \\
\text { 0. Two joint sets } \\
\text { E. Two joint sets plus random } \\
\text { F. Three joint sets } \\
\text { G. Throe joine sets plus random } \\
\text { H. Four or more joint sets. } \\
\text { rondon. heavily jointed } \\
\text { 'sugar cube'. etc } \\
\text { J. Crushed rock. earthlike }\end{array}$ & $\begin{array}{l}3 n \\
0.5-1.0 \\
2 \\
3 \\
4 \\
6 \\
9 \\
12 \\
\\
15 \\
20\end{array}$ & $\begin{array}{l}\text { 1. For Intersectlons use }\left(3.0 \times J_{n}\right) \\
\text { 2. For portals use }\left(2.0 \times J_{n}\right)\end{array}$ \\
\hline 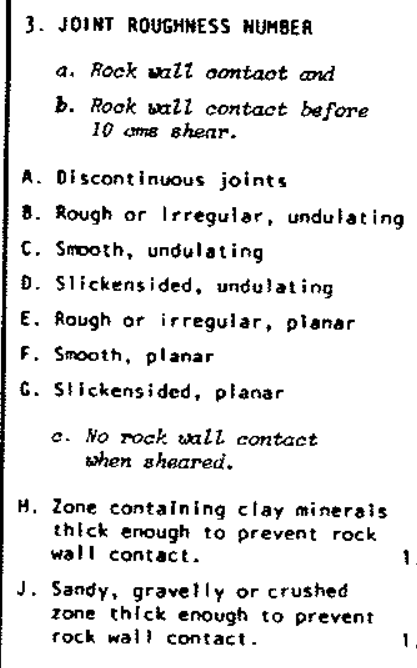 & $\begin{array}{r}4 \\
3 \\
2 \\
1.5 \\
1.5 \\
1.0 \\
0.5\end{array}$ & $\begin{array}{l}\text { 1. Add } 1.0 \text { if the mean spacing of the } \\
\text { relevant jolnt set is greater than } 3 \mathrm{~m} \text {. } \\
\text { 2. Jr }=0.5 \text { can be used for planar. slick- } \\
\text { ensided joints having liveations, provided } \\
\text { the lineations ore orientated for minimum } \\
\text { strength. }\end{array}$ \\
\hline $\begin{array}{l}\text { 4. JoINT ALTERation Number } \\
\text { a. Rock walt contact. } \\
\text { A. Tightly healed, hard, non- } \\
\text { softenlng, impermeable fllling }\end{array}$ & 0.75 & Ar (approx.) \\
\hline
\end{tabular}

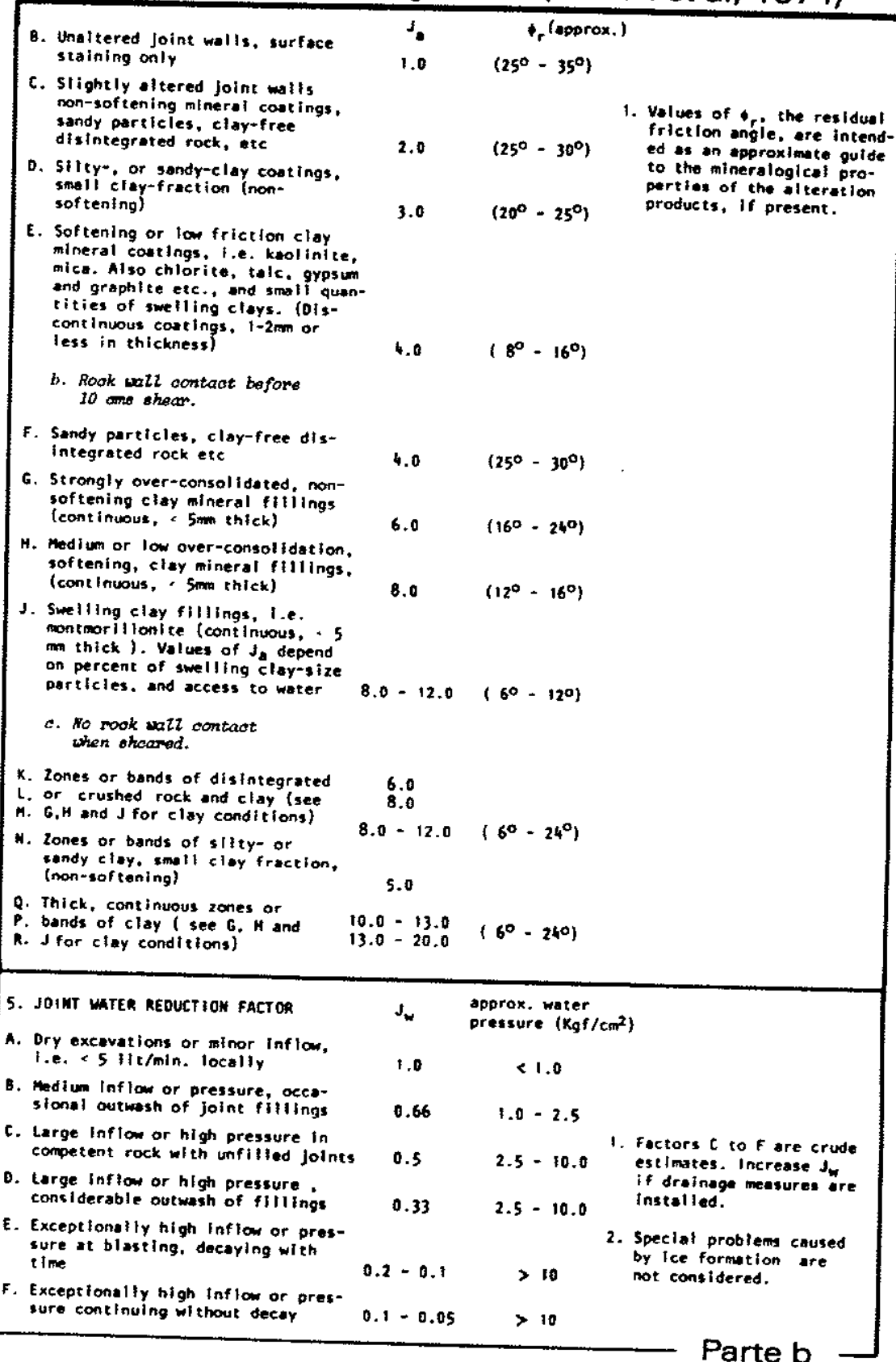




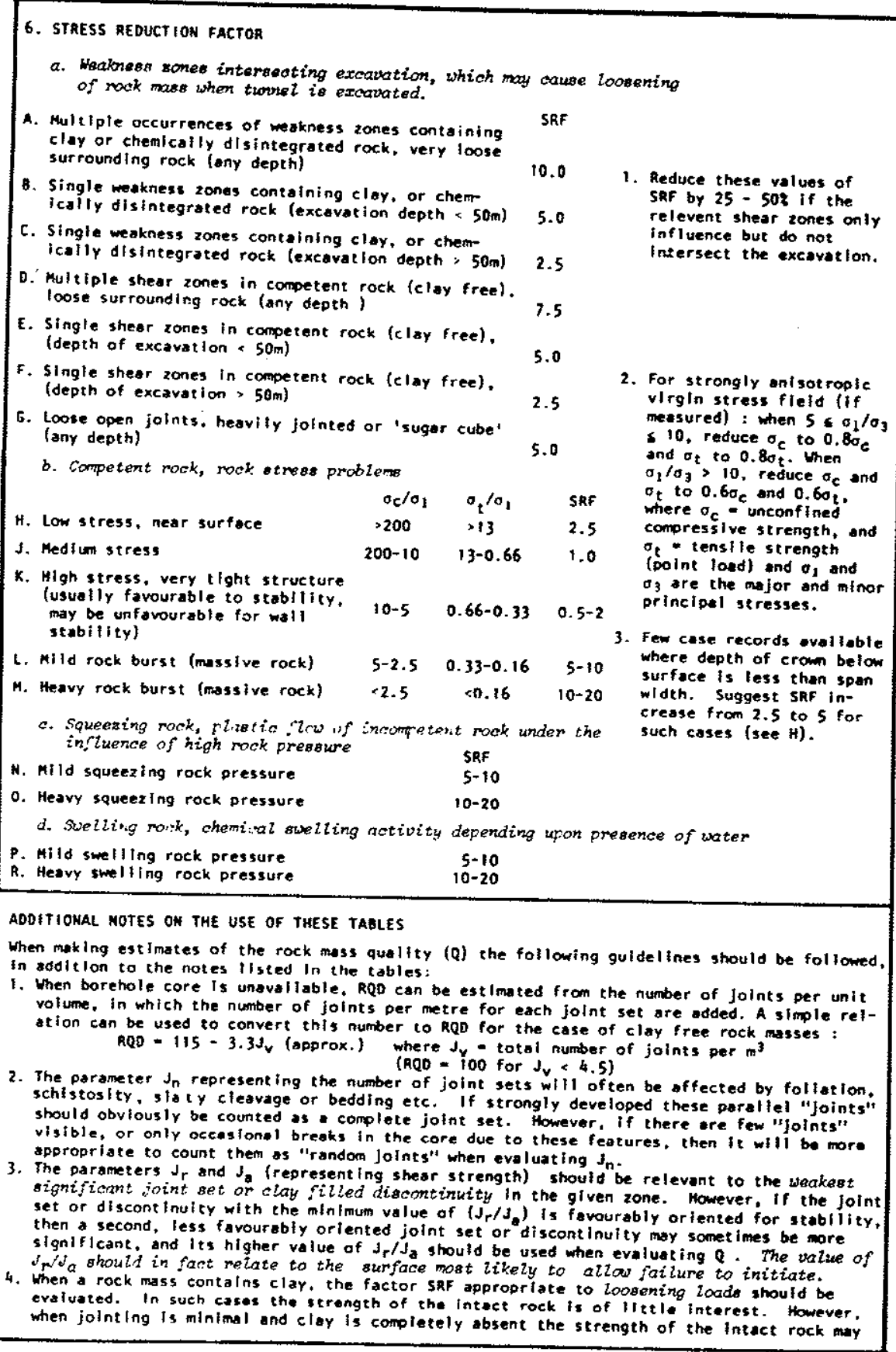

Tabela VI.3.4

Parte c 
Como vimos, as classificações anteriores foram desenvolvidas a partir do estudo $e$ observações de túneis e outras obras subterrâneas, sendo posteriormente adaptadas para utilização em escavações de taludes.

ROMANA (1985), decidiu propor uma classificação geomecânica de maciços, específica para taludes. A nova classificação, designada SMR ("Slope Mass Rating"), resultou basicamente de modificações introduzidas por Romana no sistema RMR de Beniawski.

Para isso, ele considerou alguns fatores de correção devidos às influências das juntas, alem de um fator devido à influência do método de escavação utilizado.

O SMR é um valor quantitativo definido pela expressão:

$$
\begin{aligned}
& \mathrm{SMR}=\mathrm{RMR}+(\mathrm{F} 1 \times \mathrm{F} 2 \times \mathrm{F} 3)+\mathrm{F} 4 \\
& \text { Onde: } \mathrm{F} 1= \text { fator de correção devido ao ângulo entre as direções } \\
& \text { da junta } e \text { da face do talude }(\mathrm{F} 1=1-\operatorname{sen} \mathrm{Aj}) . \text { Ele } \\
& \text { varia de } 1,00 \text { para } \mathrm{Aj} \sim 0^{\circ} \text {, até } 0,15 \text { para } \mathrm{Aj}>30^{\circ} . \\
& \mathrm{F} 2= \text { fator de correção devido ao ângulo de mergulho da } \\
& \text { junta }\left(\mathrm{F} 2 \sim \mathrm{tg}^{2} \mathrm{Bj}\right) . \text { Ele varia de } 1,00 \text { para } \mathrm{Bj}>45^{\circ} . \\
& \text { até } 0,15 \text { para } \mathrm{Bj}<20^{\circ} . \\
& \mathrm{F} 3= \text { fator de correção devido à posição relativa dos } \\
& \text { planos da junta (mergulho Bj) e do talude } \\
& \text { (mergulho Bs). Para juntas e taludes paralelos } \\
&(\mathrm{Bj}=\mathrm{Bs}) \text { é boa a condição de estabilidade. Para } \\
& \text { juntas com mergulho maior que o talude }(\mathrm{Bj}>\mathrm{Bs}), \\
& \text { temos a condição potencial de tombamento. Para } \\
& \text { juntas com mergulho } 10^{\circ} \text { inferior ao mergulho do } \\
&\text { talude (Bs } \left.-\mathrm{Bj}>10^{\circ}\right), \text { temos uma condição de } \\
& \text { estabilidade muito desfavorável. } \\
& \mathrm{F} 4= \text { fator de correção empírico, devido ao método de } \\
& \text { escavação utilizado. }
\end{aligned}
$$

Na Tabela VI.3.5., estão relacionados valores de ajustes devidos às juntas, dependendo da influência dos fatores F1, F2, F3, em diferentes casos.

A Tabela VI.3.6., indica o fator de correção F4, para cada método de escavação do talude. Como se observa nessa tabela, para taludes naturais intactos, o fator de correção F4 a ser aplicado é de +15 , diminuindo para +10 no caso de escavação com "pré-splitting", termo usado para um desmonte controlado precedido de préfraturamento da rocha. $\mathrm{O}$ fator $\mathrm{F} 4$ diminue um pouco mais, passando a +8 quando o método usado é desmonte cuidadoso (usualmente chamado "fogo 
cuidadoso") e fica zerado para o desmonte comum com explosivo ou máquina escavadeira. Para casos de desmonte a fogo sem controle, a estabilidade fica muito prejudicada e F4 se torna negativo, podendo diminuir até - 8 .

Após introduzidas as correções, Romana propôs a classificação SMR, conforme apresentado na Tabela V1.3.7., que ele chamou de primeira tentativa, considerando a possibilidade de posteriores modificações.

Tal trabalho, sendo específico para taludes, pode servir como base para análises regionais de risco de ruptura, permitindo estabelecer valores quantitativos muito úteis na elaboração de cartas geológico-geotécnicas. 
Tabela VI.3.5. Valor de ajuste devido às juntas (Romana, 1985)

\begin{tabular}{|c|c|c|c|c|c|}
\hline Cene & Very faporable & Faoorable & Fair & Unfarmothle & Very unfavorable \\
\hline $\begin{array}{l}T\left|a_{1}-a_{1}\right| \\
\left|\left(c_{1}-a_{1}\right)-\right| 80^{\circ} \mid\end{array}$ & $>30^{\circ}$ & $30-20$ & $20-10$ & 10.5 & $<5$ \\
\hline 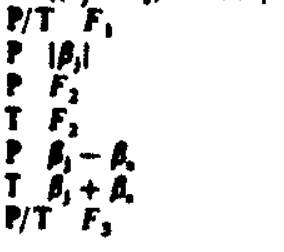 & $\begin{array}{l}0.15 \\
<20^{\circ} \\
0.15 \\
1 \\
>10^{\circ} \\
<110^{\circ} \\
0\end{array}$ & $\begin{array}{c}0.40 \\
20-30 \\
0.40 \\
1 \\
10-0^{\circ} \\
110-120^{\circ} \\
-6\end{array}$ & $\begin{array}{c}0.70 \\
30-35 \\
0.70 \\
1 \\
0^{\circ} \\
>120 \\
-25\end{array}$ & $\begin{array}{c}0.85 \\
35-45 \\
0.85 \\
1 \\
0 " \text { to }-10 \\
- \\
-50\end{array}$ & $\begin{array}{c}1.00 \\
>45^{\prime \prime} \\
1.00 \\
1 \\
<-10^{\circ} \\
-60\end{array}$ \\
\hline
\end{tabular}

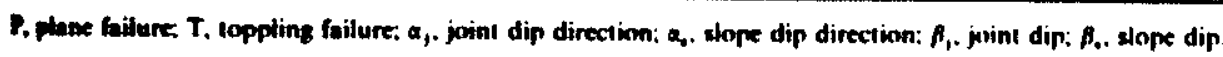

Tabela VI.3.6. Valor de ajuste devido ao método de escavação (Romana, 1985)

\begin{tabular}{lccccc}
\hline Method & $\begin{array}{c}\text { Nasural } \\
\text { slope }\end{array}$ & Presptitting & $\begin{array}{c}\text { Smowth } \\
\text { blasting }\end{array}$ & $\begin{array}{c}\text { Blastiny or } \\
\text { merhanical }\end{array}$ & $\begin{array}{c}\text { Deficient } \\
\text { blasting }\end{array}$ \\
\hline$F_{4}$ & +15 & +10 & +8 & 0 & +8 \\
\hline
\end{tabular}

Tabela VI.3.7. Classificação SMR (Romana, 1985)

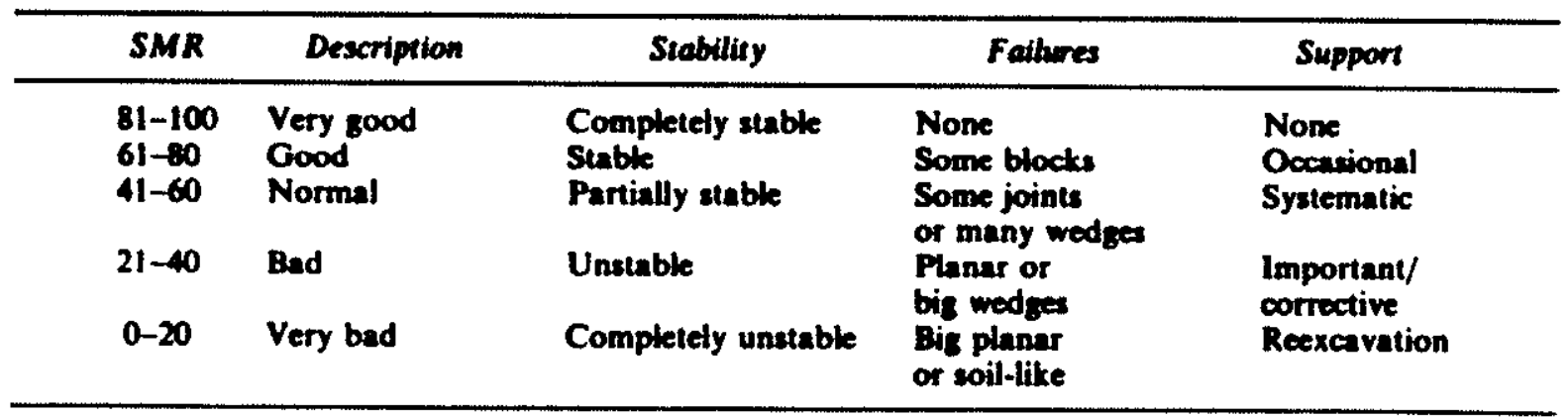




\section{VI.4. ANÁLISE DE ESTABILIDADE DE TALUDES}

\section{VI.4.1. Parâmetros de Estabilidade}

Existem inúmeros fatores que influenciam a estabilidade das encostas, conforme já comentado, que devem ser considerados na análise de cada caso.

Para a discussão genérica da estabilidade de taludes entretanto, os parâmetros físicos mais relevantes e determinantes da resistência ao cisalhamento dos maciços de solos e rochas, são a coesão e o ângulo de atrito interno. Como já vimos, no caso de maciços rochosos, as descontinuidades devem merecer um estudo especial. O significado da coesão e do ângulo de atrito fica melhor entendido, quando relacionado com as tensões normal e cisalhante atuantes num bloco de material na condição limite de ruptura, conforme mostrado na Figura VI.4.1.1. e que pode ser definida na expressão geral da sua "resistência ao cisalhamento" (I):

$$
\begin{aligned}
& \zeta=c+\sigma \tan \phi \\
& \sigma=\text { tensão normal } \\
& c=\text { coesão } \\
& \phi=\text { ângulo de atrito interno }
\end{aligned}
$$

Na Tabela VI.4.1.1., estão indicados alguns valores típicos de coesão (c), ângulo de atrito $(\phi)$ e peso específico, obtidos para diferentes tipos de materiais.

Observa-se na tabela, que a coesão atinge os valores mais elevados (35000 a $55000 \mathrm{kPa}$ ) para rochas duras ígneas como granito e basalto, diminuindo bastante para as argilas em geral e caindo a zero para as areias, cascalhos $e$ rochas fragmentadas. Quanto ao ângulo de atrito, atinge valores de $45^{\circ}$ para rochas duras, podendo alcançar valores ainda maiores para algumas areias, cascalhos e rochas duras fragmentadas. Valores inferiores a $35^{\circ}$ são encontrados para as argilas glaciais $e$ areias soltas, sendo os ângulos mais baixos os das argilas moles, especialmente as orgânicas e a bentonita.

$\mathrm{O}$ peso específico (saturado e seco), tambem tem os valores mais altos para as rochas duras $\left(25\right.$ a $30 \mathrm{kN} / \mathrm{m}^{3}$ ), caindo geralmente abaixo de 20 para os outros mateirais e atingindo os valores mais baixos para as argilas moles orgânicas e a bentonita, 


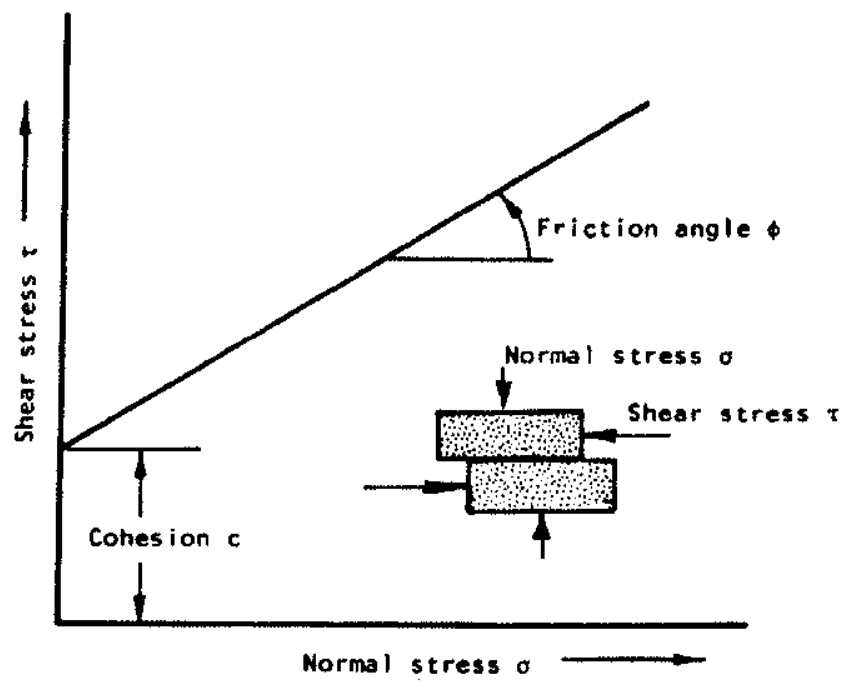

Figura VI.4.1.1. Tensões normal e cisalhante num bloco de solo ou rocha na condição limite de ruptura (Hoek e Bray, 1997)

Tabela VI.4.1.1. Parâmetros típicos de solos e rochas (Hoek e Bray, 1997)

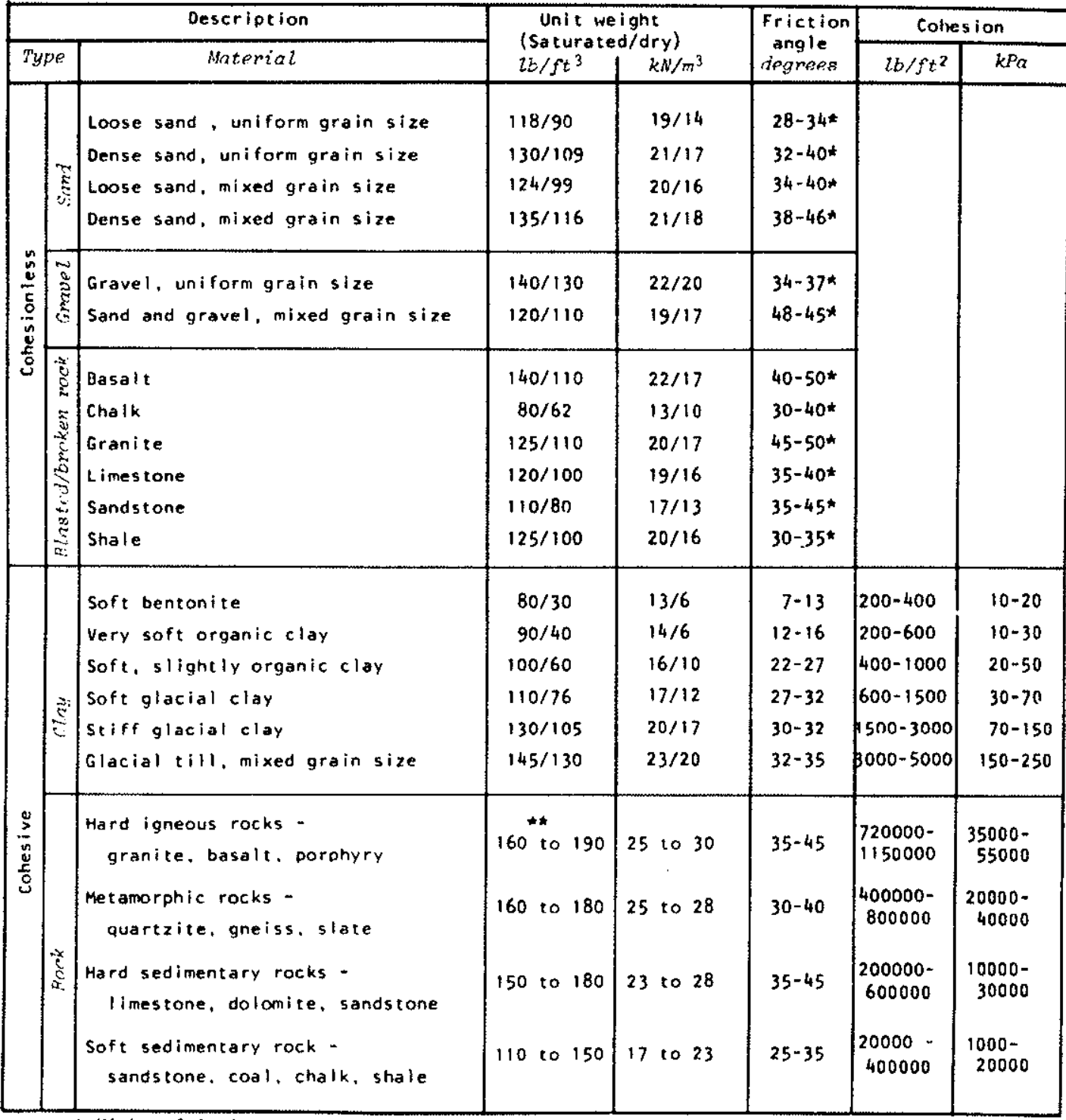

* Higher friction angles in cohesionless materials occur at low confining or normal stresses

** For intact rock, the unit weight of the material does not vary significantly between saturated and dry states with the exception of materials such as porous sandstones. 
VI.4.2. Fator de Segurança de um Talude.

Consideremos inicialmente a condição geral de equilibrio em um talude com presença de água, onde individualizamos um bloco, representando as principais forças atuantes, conforme esquematizado na Figura VI.4.2.1:

Estando na condição de equilíbrio, a resultante de todas as forças atuantes no bloco é igual a zero, por definição. Assim sendo, a somatória das forças que tendem a levar o bloco ao cisalhamento é igual à somatória das forças resistentes, conforme a expressão:

$$
W \operatorname{sen} \psi+V=c A+(W \cos \psi-U) \tan \phi
$$

$$
\text { Onde: } \begin{aligned}
W & =\text { Força peso do bloco } \\
\Psi & =\text { Ângulo do talude } \\
V & =\text { Parcela da força cisalhante devida à água } \\
c & =\text { coesão do material do maciço } \\
\mathrm{A} & =\text { Área de contacto do bloco com a superfície de } \\
\text { ruptura potencial } & \\
U & =\text { Parcela negativa da força normal devida à água } \\
\phi & =\text { Ângulo de atrito interno do material do maciço }
\end{aligned}
$$

A expressão de forças (II) é tambem o desenvolvimento da expressão (I), já apresentada, considerando a aplicação das tensões cisalhante $(\boldsymbol{\sigma})$ e normal $(\sigma)$, na área A do bloco, isto é:

$$
\begin{aligned}
& \sigma A=W \operatorname{sen} \psi+V \\
& \sigma A=W \cos \psi-U
\end{aligned}
$$

Podemos melhorar a estabilidade do bloco, aplicando ao mesmo a força $T$ de um tirante, o que significa aumentar a resultante das forças resistentes, conforme indicado na Figura VI.4.2.2., aonde $\beta$ é o ângulo vertical entre $\circ$ tirante e o talude.

As componentes de T, introduzidas em (II), resultam na expressão geral de forças num bloco atirantado:

$$
\mathrm{W} \operatorname{sen} \psi+V-T \cos \beta=\mathrm{cA}+(\mathrm{W} \cos \psi-U+T \operatorname{sen} \beta) \tan \phi
$$

O Fator de Segurança FS, tambem conhecido como coeficiente de segurança é definido pela relação entre as forças resistentes $e$ as forças que tendem a provocar o cisalhamento do bloco (favorecem o deslizamento do bloco). 


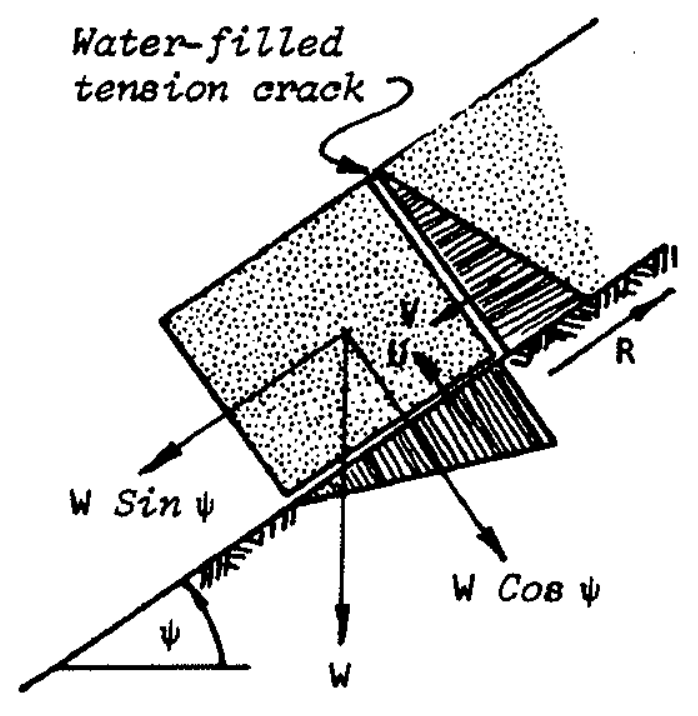

Figura VI.4.2.1. Forças atuantes num bloco em equlibrio (Hoek e Bray, 1997)

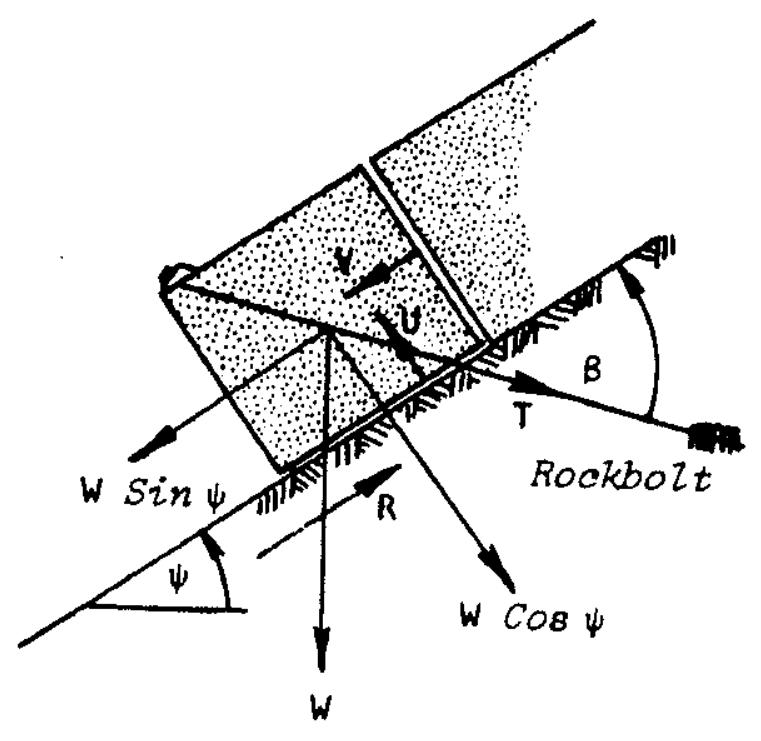

Figura VI.4.2.2. Equilíbrio de forças num bloco atirantado (Hoek e Bray, 
No caso esquematizado, o fator de segurança do bloco pode ser considerado o fator de segurança do talude.

A partir de (III), obtemos o fator de segurança, definido pela expressão seguinte:

$$
F S=\frac{c A+(W \cos \psi-U+T \operatorname{sen} \beta) \tan \phi}{W \operatorname{sen} \psi+V-T \cos \beta}
$$

O fator de segurança utilizado varia em função do tipo de obra e do seu carater transitório (caso de contenções provisórias) ou permanente.

Para escavações e contenções provisórias, pode-se usar FS em torno de 1,2 a 1,3. Para obras definitivas, ele varia geralmente de 1,3 a 1,5, dependendo do tipo de projeto.

Muitas vezes, estão embutidos no fator de segurança utilizado, aspectos de incertezas dos projetistas, tanto em relação aos valores corretos dos parâmetros ce $\phi$, como em relação ao peso da massa instabilizada. Além disso, pode haver perda da força $T$ de protensão do tirante com o passar do tempo, por acomodação da rocha e redistribuição de tensões no maciço. Por essa razão, se usam Fatores de segurança teoricamente elevados, como 1,5, ou mais. Em maciços sob a influência de pressóes elevadas de água, ou em solos plásticos, tambem se costuma usar FS elevado.

Para cada caso portanto, o fator de segurança a ser utilizado deverá levar em conta os parâmetros intervenientes na estabilidade e a confiança que se pode ter na representatividade dos seus valores, bem como o objetivos do projeto e o tipo de obra que se está analisando.

Será sempre conveniente o acompanhamento geológico-geotécnico executivo de uma obra de estabilização, fazendo se possivel, novas amostragens durante as perfurações dos tirantes, aferindo os parâmetros utilizados e as premissas de projeto. Nunca podemos esquecer que, em maciços rochosos fraturados é preponderante a influência das juntas, conforme já comentamos em capítulo anterior. Nesses casos, o mapeamento das juntas deve ser considerado na compartimentação do maciço, orientando o projetista sobre eventuais ajustes.

Um monitoramento periódico posterior à execução da obra de contenção, através de instrumentação geomecânica, tambem é aconselhável. Isso foi feito na Rodovia dos Imigrantes, onde os muros principais contaram com a instalação de células de controle de carga em alguns tirantes, monitorando assim a variação da força $\mathrm{T}$ de atirantamento no passar do tempo. 


\section{VI.4.3. Altura X Inclinação}

Para cada tipo de material, existe uma relação entre a altura máxima possivel e o ângulo de inclinação do talude com com o plano horizontal. $O$ assunto foi estudado por vários autores interessados em conhecer essa relação altura $X$ inclinação e estabelecer assim a condição crítica para a estabilidade do talude.

$\mathrm{Na}$ Figura VI.4.3.1., estão esquematizados 5 casos típicos de rupturas em taludes, em diferentes materiais, cada qual com sua relação "altura X inclinação", para as condições seca e saturada Estão representadas tambem as curvas de ruptura, em gráficos "tensão cisalhante X tensão normal", em cada caso.

Observando a figura, vemos que o primeiro caso, corresponde a uma situação teórica de um talude em rocha maciça intacta, com acamamento horizontal mas sem a influência de juntas, o qual se manteria estável mesmo com alturas enormes, da ordem de quilômetros. Isso se daria com inclinações de até $60^{\circ}$ na condição saturada e de até $75^{\circ}$ na condição seca. Trata-se evidentemente de uma situação teórica irreal.

No segundo caso, existe uma descontinuidade aberta até um determinado nível do maciço, condicionando a ruptura por cizalhamento a partir deste ponto. $\mathrm{O}$ talude se mantem estável com alturas consideráveis, de centenas de metros, para inclinação inferior a $35^{\circ}$ na condição saturada e $45^{\circ}$ na condição seca.

O terceiro caso, corresponde a um maciço onde existe um sistema predominante de descontinuidades cortando tangencialmente a superfície do talude, alem de um outro sistema secundário, aproximadamente normal ao primeiro. A ruptura resultante é do tipo em degraus, sendo que a altura máxima estável tende ao infinito, para inclinação inferior a $45^{\circ}$ na condição saturada, ou inferior a $52^{\circ}$ na condição seca.

No quarto caso, representativo de maciço rochoso extremamente fraturado $e \mathrm{em}$ várias direções, a superfície de ruptura é aproximadamente circular. A estabilidade do talude se mostra mais desfavorável que nos casos anteriores, sendo considerado o valor zero para sua coesão, bem como valores variáveis para o ângulo de atrito do material, dependendo da posição considerada no maciço $e$ da situação das tensões. Comparativamente, observamos que as alturas máximas estáveis para o talude são bem menores neste caso, mesmo considerando-se ângulos de inclinação bem inferiores. 
T2920

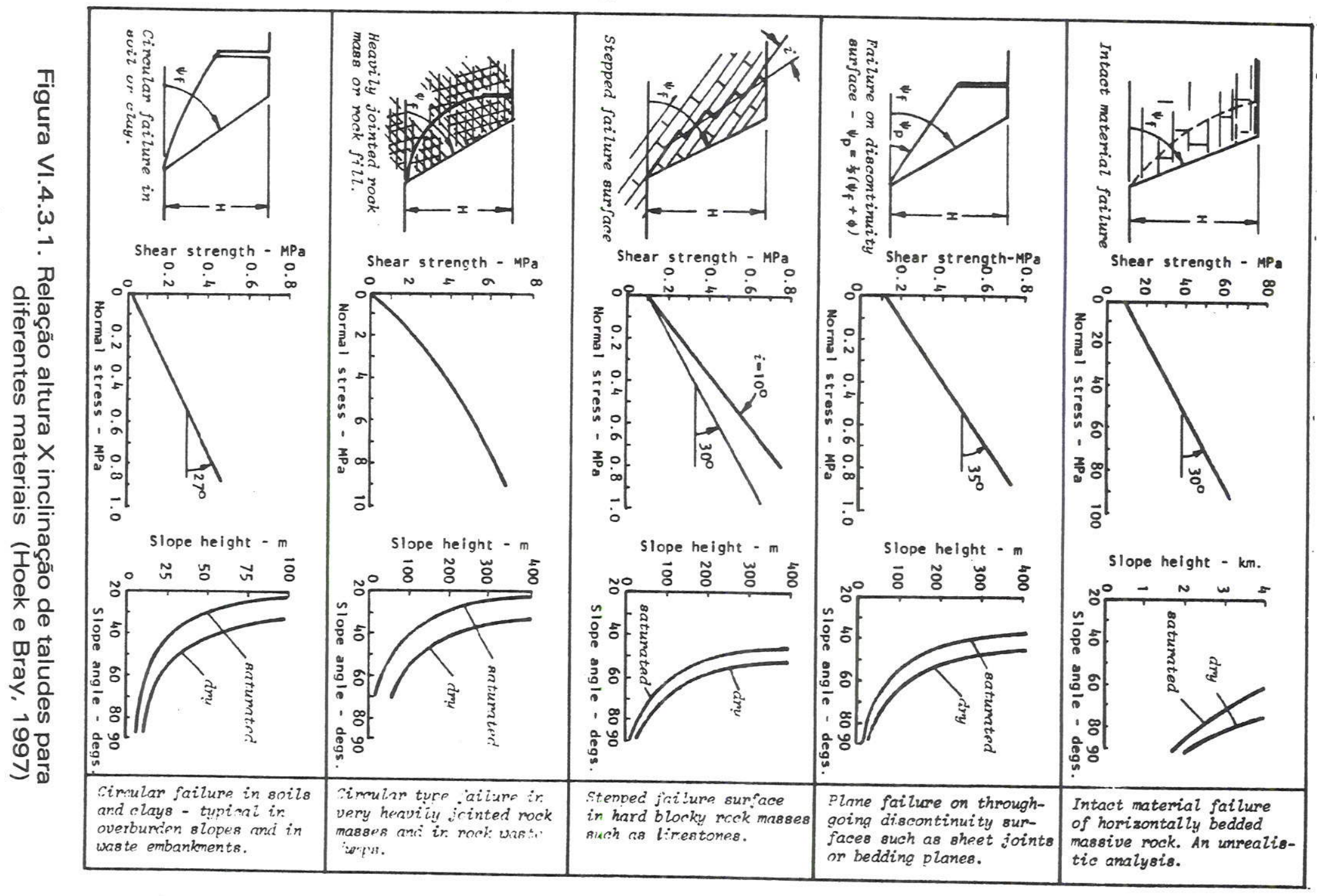


O quinto caso, representa ruptura num solo argiloso, condicionado por uma descontinuidade. A ruptura por cisalhamento se dá a parïr da base da fratura,segundo uma superfície circular. A forma tem semelhança geométrica com o segundo caso, entretanto os valores de coesão e ângulo de atrito são bastante inferiores, bem como as alturas máximas estáveis para os mesmos ângulos de inclinação.

Pesquisando a influência dos parâmetros de estabilidade em taludes escavados em rochas duras, com padrão variado de descontinuidades, HOEK (1995) utilizou mais de uma centena de dados compilados por KLEY (1967) e ROSS-BROWN (1973), referentes a obras de escavação de minas, galerias, fundações de barragens, cortes rodoviários, etc. Elaborou um gráfico, relacionando altura $\mathrm{X}$ inclinação dos taludes, traçando a curva probabilística de estabilidade, conforme mostrado na Figura VI.4.3.2.

$\mathrm{O}$ autor atribue a diferença de comportamento entre os taludes (estáveis $e$ instáveis), basicamente à influência das descontinuidades.

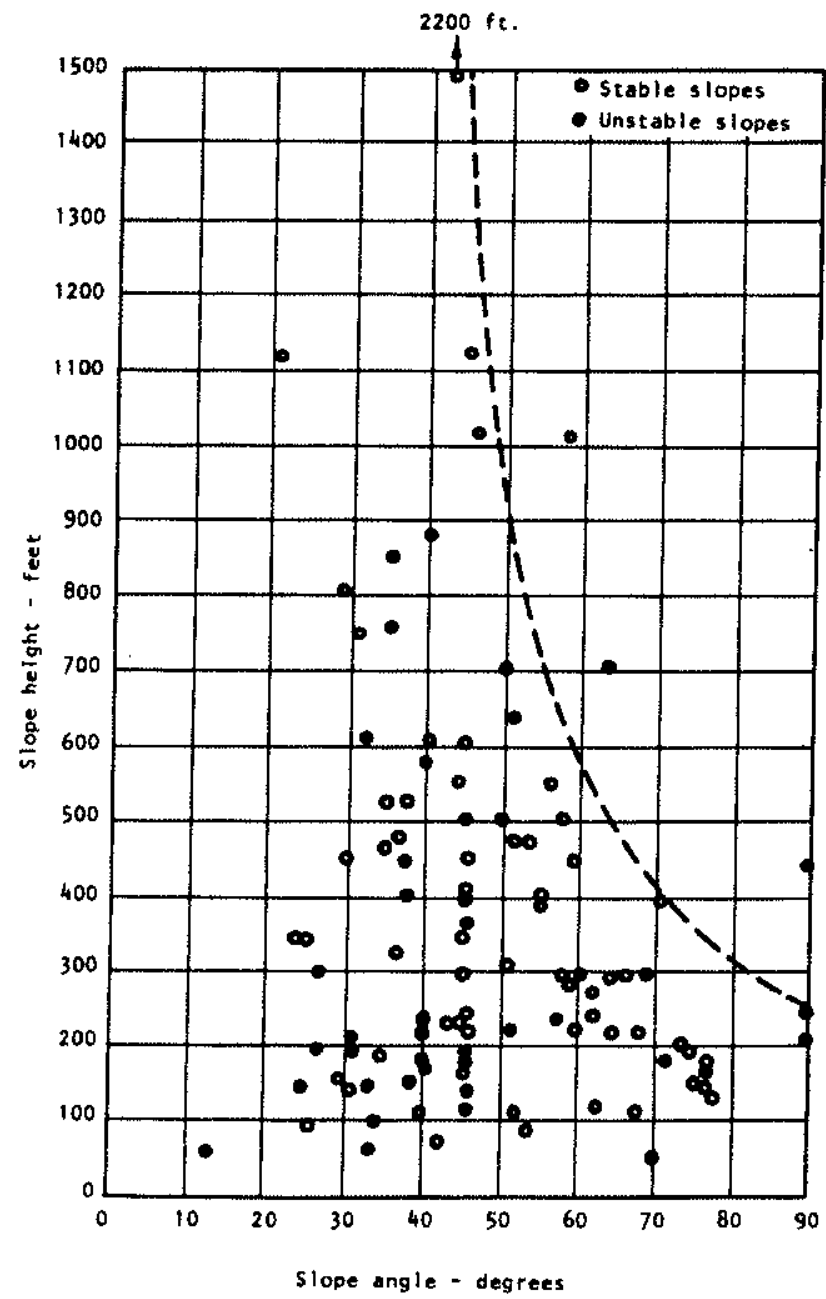

Figura VI.4.3.2. Altura $X$ inclinação de taludes em rochas duras (Hoek, 1995) 


\section{Vl.4.4. Critérios de Ruptura}

Critérios de ruptura, constituem hipóteses elaboradas por diversos pesquisadores, na tentativa de predizer quantitativamente as condições sob as quais um material sofre ruptura, quando submetido a um determinado regime de esforços.

No caso de um maciço de rocha ou solo, submetido a um determinado estado de tensões, significa estabelecer a sua condição de resistência limite, na qual se dá a ruptura ("ponto de ruptura").

Para entender melhor o comportamento de um material submetido a esforços e que vai deformando até o limite de ruptura, podemos observar dois casos típicos de ensaios esquematizados nas Figuras VI.4.4.1. e VI.4.4.2.

$\mathrm{O}$ primeiro caso, corresponde ao comportamento tensão $\mathrm{X}$ deformação de um material elásto-plástico. Os metais em geral tem esse comportamento, existindo um ponto de inflexão na curva ("yield point") correspondendo à mudança do regime elástico para o plástico. O regime plástico perdura até o limite de resistência do material, quando se dá a ruptura, caracterizada por uma queda brusca de tensão, permanecendo a deformação constante.

O segundo caso, corresponde ao comportamento apresentado por um material elástico. O ferro ou o vidro, tem esse tipo de comportamento, onde existe uma relação constante entre os incrementos da tensão e da deformação, resultando numa linha reta para o regime elástico, até atingir o ponto de ruptura.

Os materiais naturais constituintes de encostas e taludes (solos e rochas), normalmente apresentam comportamentos variando entre os dois tipos apresentados, isto é, nem são tão elásto-plásticos como os metais, nem tão elástico como o ferro ou o vidro. Sabemos ainda que, enquanto nos metais a resistência não varia com a pressão confinante, nos materiais ditos pétreos, a resistência aumenta com o confinamento (critério de Nouvier-Coulomb).

Entretanto, como neste tipo de estudo os maciços estão normalmente sob condições de baixa tensão confinante, eles muitas vezes apresentam comportamento mais próximo do segundo caso que do primeiro. Significa que, após o regime elástico, existe um ponto de inflexão para o regime plástico ("yield point"), quase imediatamente seguido da ruptura. A característica rúptil do material é portanto predominante, pois a ductibilidade é própria de condições de altas tensões em profundidade. 


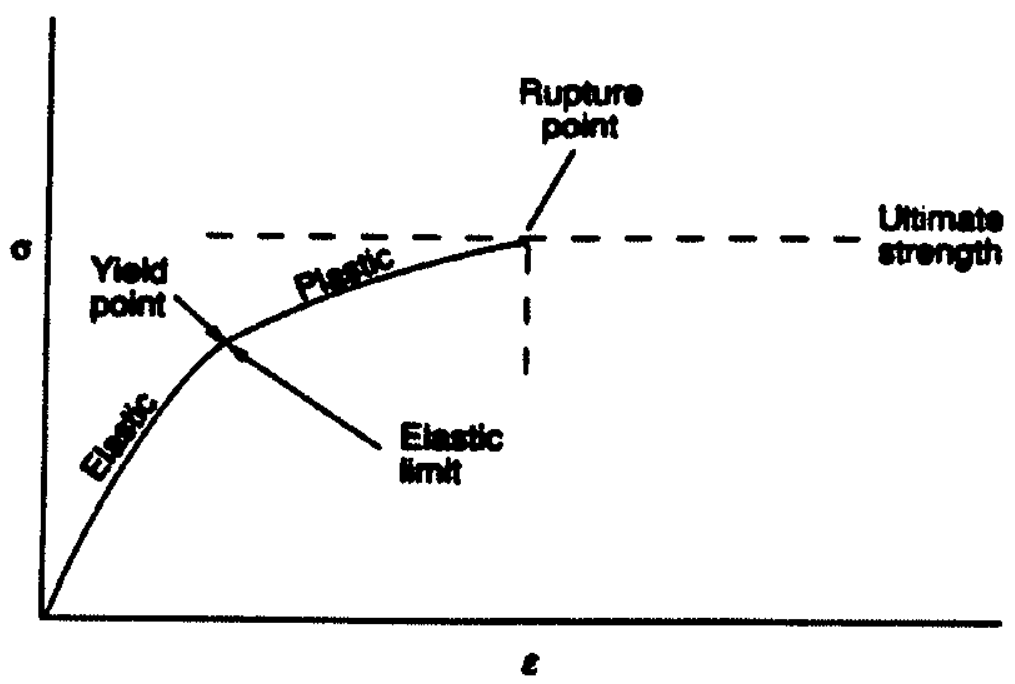

Figura VI.4.4.1. Curva tensão $X$ deformação de material elasto-plástico(Hatcher Junior, 1995)

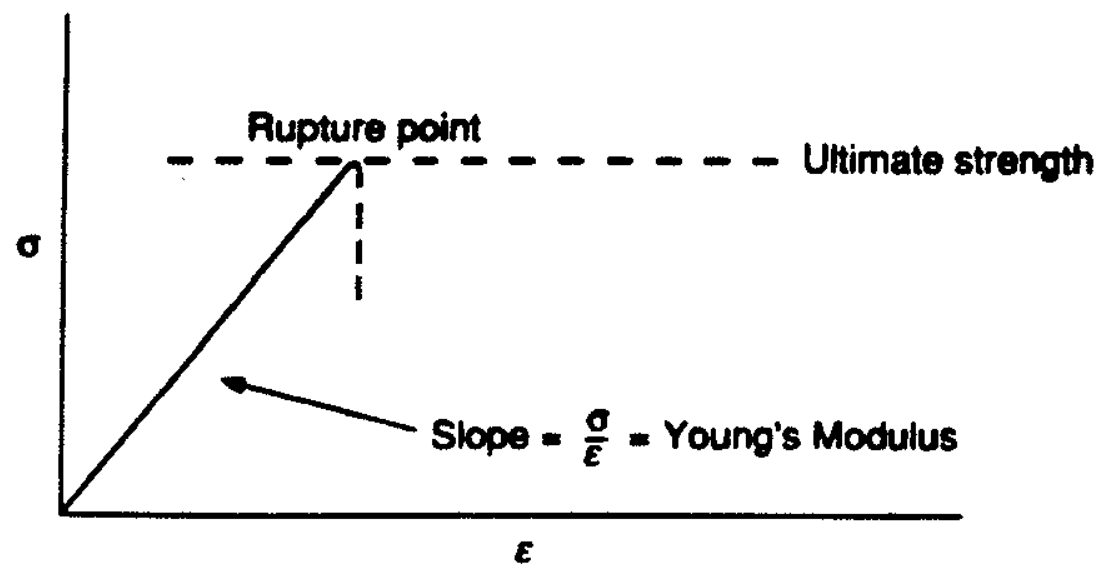

Figura VI.4.4.2. Curva tensão $X$ deformação de material elástico (Hatcher Junior, 1995) 
Diversos pesquisadores propuseram critérios de ruptura, desenvolvendo considerações e teorias a respeito (Griffith, Lundborg, Macclintock e Walsh, Barton, Hoek, Jaeger e Cook, entre outros). Os autores, de modo geral, levaram em conta as condições de tensão a que estão submetidos os materiais e suas aplicações a diferentes tipos de projetos, tanto em obras superficiais como subterrâneas.

Para o estudo de estabilidade de taludes de solos e rochas, os critérios mais adequados se baseiam nas premissas estabelecidas por Coulomb e Mohr.

Coulomb, em 1773, descreveu as condições da ruptura ao cisalhamento em rochas, relacionando as tensões cisalhante e normal, atuantes num plano. Através de ensaios para alguns materiais, obteve uma linha reta, definida pela expressão (I) já discutida em VI.4.1., isto é:

$$
\zeta=c+\sigma \tan \phi
$$

Como sabemos, constitue a equação de uma reta com coeficiente angular $\tan \phi$, interceptando o eixo das ordenadas em $\underline{c}$.

Esse critério, passou posteriormente a ser representado utilizando o círculo de Mohr, conforme mostrado na Figura VI.4.4.3., passando a ser conhecido como critério de Mohr-Coulomb.

O material de coesão c e ângulo de atrito interno $\phi$, representado pela reta r, está submetido ao estado de tensões $\sigma 1$ (tensão principal máxima) e $\sigma 3$ (tensão principal mínima) representado pelo círculo de Mohr e alcança sua condição de ruptura no ponto X. Esse ponto, como sabemos, representa o polo do próprio plano de ruptura, que faz ângulo de inclinação $\theta$ com a normal a $\sigma 1$.

As coordenadas de $\mathrm{X}$, constituem a expressão $(\mathrm{V})$ abaixo e definem as componentes cisalhante e normal atuantes no material na condição de ruptura. Resultam de uma simples transformação da expressão geral (I) apresentada acima):

$$
\begin{aligned}
& \zeta=1 / 2(\sigma 1-\sigma 3) \operatorname{sen} 2 \theta \\
& \sigma=1 / 2(\sigma 1+\sigma 3)+1 / 2(\sigma 1-\sigma 3) \cos 2 \theta
\end{aligned}
$$

Mohr, a partir da conceituação de Coulomb, realizou uma série de ensaios, estabelecendo a envoltória de ruptura para diferentes materiais, conforme esquematizado na Figura VI.4.4.4. Verificou que na verdade a envoltória não é uma linha reta, conforme considerado por Coulomb, existindo um trecho médio reto significativo, mas tambem curvaturas côncavas voltadas para baixo nas extremidades. O ponto B da figura, representa a ruptura do material para o círculo de Mohr com centro em $\mathrm{C}$ 


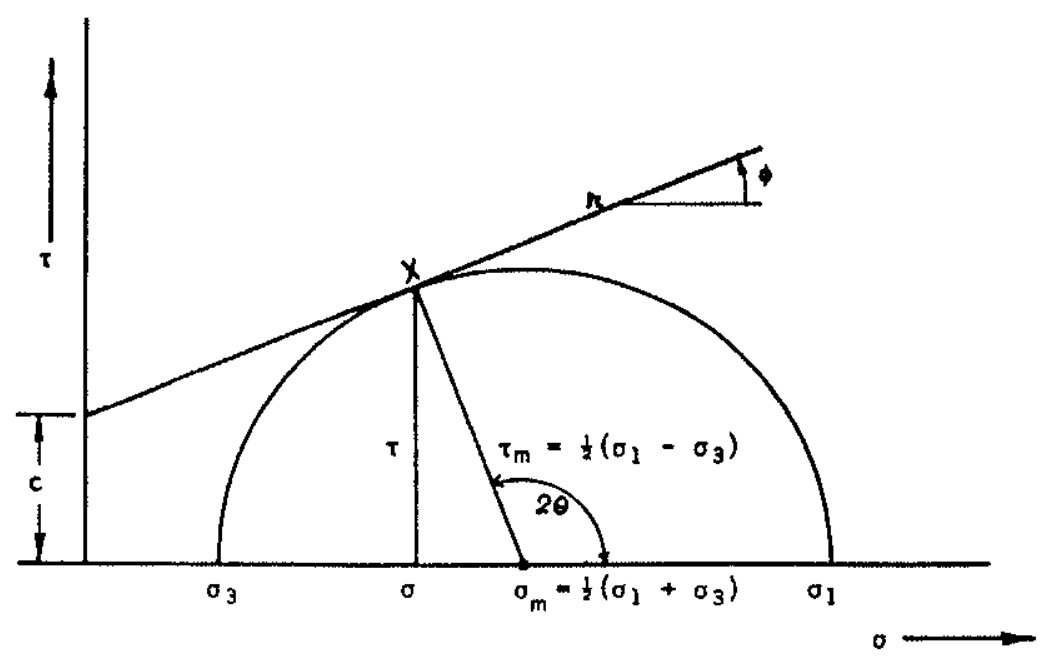

Figura VI.4.4.3. Critério de ruptura de Mohr-Coulomb

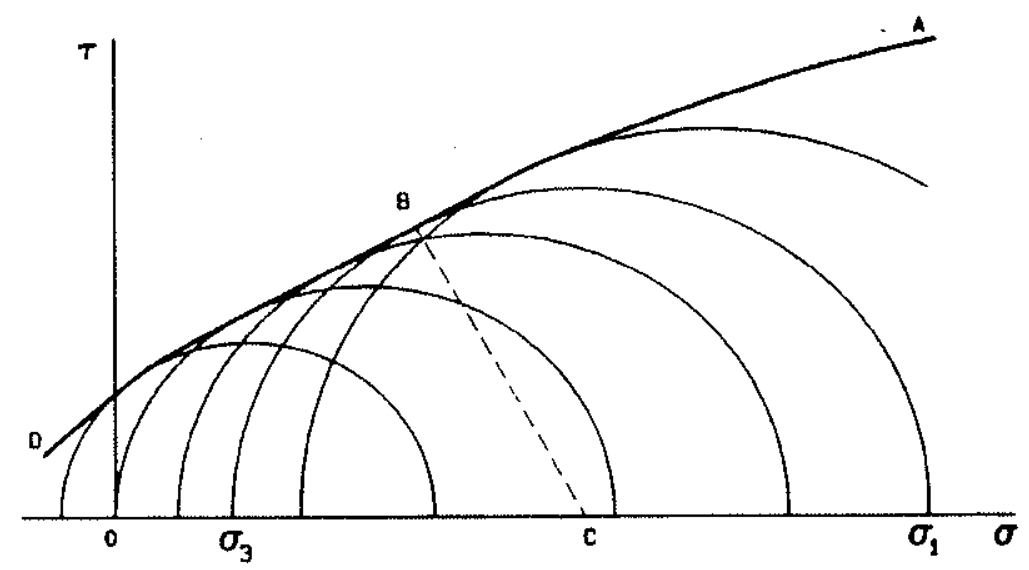

Figura VI.4.4.4. Envoltória de Mohr 


\section{VI.4.5. Métodos de Análise}

Existem diversos métodos, envolvendo conjuntos de processos, na tentativa de estabelecer um índice ou grandeza que permita avaliar o risco de ruptura de um talude ou encosta.

Esses métodos, podem ser divididos genericamente em analíticos, experimentais $e$ observacionais, dependendo do enfoque considerado.

Os métodos analíticos, envolvendo a teoria de equilíbrio-limite e modelos matemáticos de tensão $\mathrm{X}$ deformação, tem sido bastante utilizados pelos projetistas, contando atualmente com o apoio de programas computacionais, conferindo-lhes bastante sofisticação. Devemos ressaltar entretanto, que nenhum método é melhor que os seus parâmetros de entrada, isto é, a qualidade e confiabilidade dos dados alimentadores desses programas (valores de coesão, ângulo de atrito, peso específico, pressão de fluidos, influência de descontinuidades, etc.) é que realmente determinam o bom resultado da análise. Alem disso, qualquer que seja o método utilizado, deve ser precedido de uma caracterização geológico-geotécnica do talude em estudo.

$\mathrm{Na}$ Tabela VI.4.5.1., são apresentados os principais métodos analíticos, com os tipos de ruptura considerados.

Os métodos analíticos convencionais ou determinísticos, ainda são os de uso mais frequente, levando em conta os diversos parâmetros que estão envolvidos no cálculo do fator de segurança FS.

Considerando que existem variabilidades básicas desses parâmetros, em relação a valores considerados médios para os diversos materiais, alguns autores procuraram desenvolver abordagens probabilísticas, utilizando valores de acordo com distribuições estatísticas. Uma dessas abordagens (GAMA, 1997), procura estabelecer o coeficiente de variação $(\mathrm{Cv})$, que deve ser levado em conta, quando se cruzam os dados do fator de segurança (FS) com a probabilidade de colapso (Pc), conforme Figura VI.4.5.1., em anexo.

O grau de segurança de um talude segundo o autor, deve ser considerado em termos probabilísticos, levando em conta o seu coeficiente de variação, qualquer que seja o valor do fator de segurança. 
Tabela VI.4.5.1. Principais métodos analíticos de análise de estabilidade (IPT, 1990)

\begin{tabular}{|c|c|c|c|}
\hline \multicolumn{2}{|c|}{ METOOOS DE ANMLIBE DE ESTABLDADE } & \multirow[b]{2}{*}{ GEOMETRAA DA FUPTURA } & \multirow[b]{2}{*}{ DNAMEA DO PAOCESSO } \\
\hline TPO & NOME & & \\
\hline Equilborio fimite & $\begin{array}{l}\text { ESPRAL LOGAPITMICA } \\
\text { TAYOR } \\
\text { FFIIFNW } \\
\text { BSSHOP } \\
\text { SPENCEA } \\
\text { TRDMENSIONAL } \\
\text { JAMBU } \\
\text { MOAGESTEPN O PRXE }\end{array}$ & Rupturas Circulares & $\begin{array}{l}\text { Nâo condicionado por estrturas } \\
\text { reliquiares }\end{array}$ \\
\hline Tensão/deformaçấo & $\begin{array}{l}\text { ELEMENTOS FNTOS } \\
\text { DIFEAENCSAS FNITAS } \\
\text { MULTBLOCOS }\end{array}$ & Rupuras no Circutares & \\
\hline Equilibrio limite & $\begin{array}{l}\text { PLANAR } \\
\text { BPLANAR, EM CUNHA } \\
\text { MULTPLANAR }\end{array}$ & $\begin{array}{l}1 \text { płano } \\
2 \text { planos } \\
\text { Vários planos }\end{array}$ & $\begin{array}{l}\text { Condicionados por estruturas } \\
\text { reliquiares }\end{array}$ \\
\hline Tensảo/deformaçáo & & Tombamento/ Queda de Blocos & \\
\hline
\end{tabular}

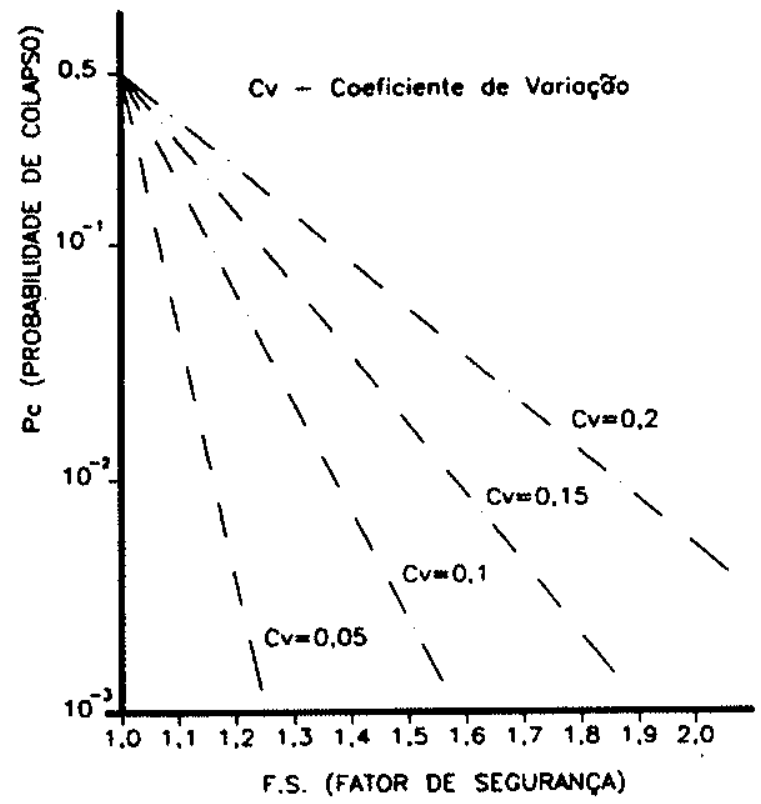

Figura VI.4.5.1. Grau de segurança de um talude em termos probabilísticos (Gama, 1997) 
Os métodos experimentais, empregando modelos físicos em diferentes escalas, tem sido usados em laboratórios, minas e canteiros de obras e, embora de uso mais restrito, por envolver custos mais elevados que os anteriormente descritos, tem a vantagem de reproduzir com maior realismo as condições dos maciços naturais.

Os métodos observacionais, são assim chamados por envolver a experiência acumulada na análise de rupturas anteriores, em condições semelhantes ou correlacionáveis com o caso em estudo.

Dentre eles se destacam as retroanálises, que partindo da situação do talude rompido, procuram ajustar os parâmetros de estabilidade, através de tentativas de chegar ao Fator de segurança 1,0, que define a condição limite de ruptura. Tendo em vista que o ângulo de atrito normalmente tem valores mais conhecidos $e$ apresenta menor dispersão, geralmente ele é pré-fixado, chegando-se ao valor da coesão por decorrência.

Um método que pode ser classificado como analítico-observacional é o da projeção estereográfica, muito importante na análise de taludes rochosos fraturados e até mesmo para alguns taludes em solo saprolítico. Desde que existam estruturas geológicas descontínuas marcantes (fraturas, juntas, falhas, xistosidades, acamamentos, etc.), esse método pode ser empregado com sucesso. Ele é muito útil para o geólogo que domina essa técnica, tendo como base o levantamento detalhado de campo das estruturas existentes no talude. Deve-se tambem escolher um valor adequado para o ângulo de atrito do material, o que não costuma ser problemático, sendo geralmente um dado disponivel.

Por esse método, podemos analisar a possibilidade de ocorrência de rupturas planares num talude, face às suas descontinuidades. Exemplificando, podemos observar algumas situações apresentadas na Figura VI.4.5.2. 

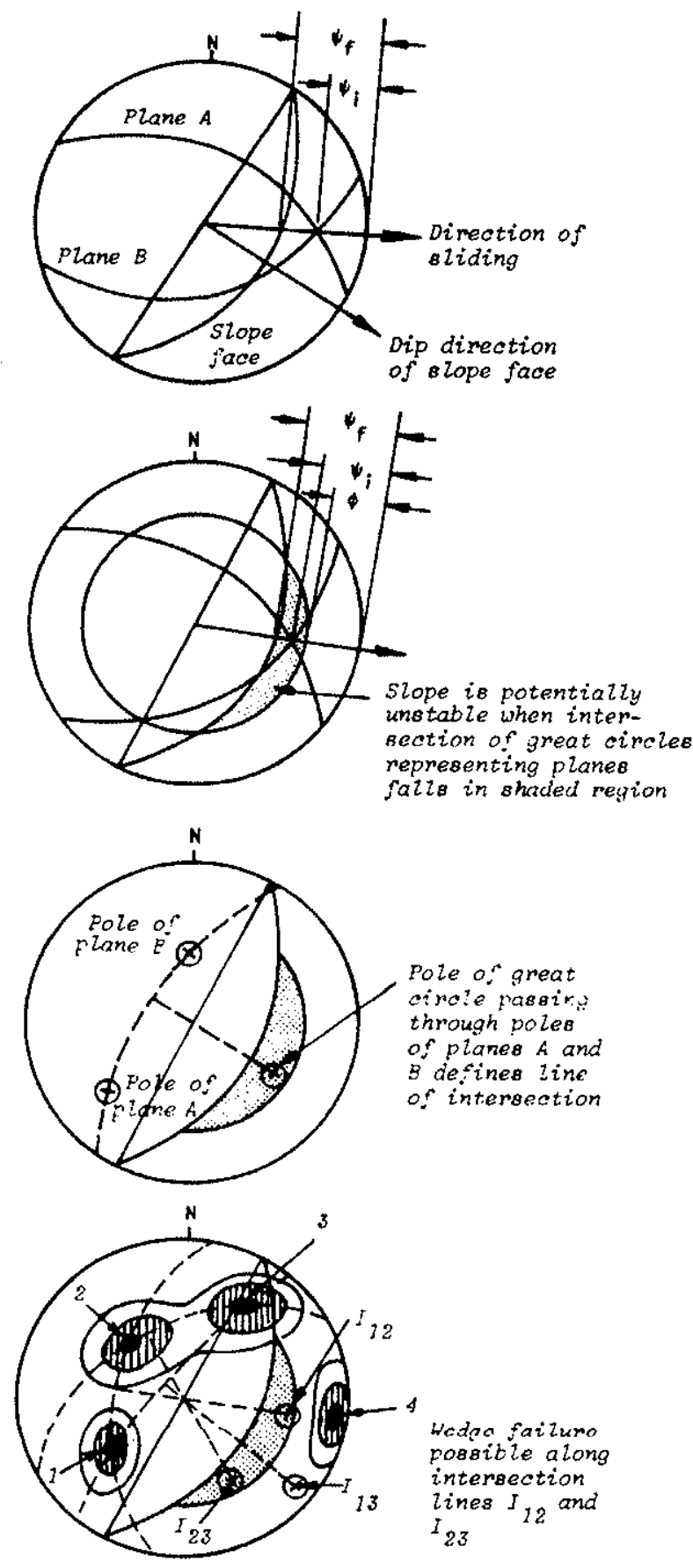

a: Sliding along the IIne of intersection of planes $A$ and $B$ is possible when the plunge of this line is less than the dip of the slope face, measured in the direction of sliding,

$$
v_{f}>v_{i}
$$

b : Sliding is assumed to occur when the plunge of the line of intersection exceeds the angle of friction, ie

$$
\psi_{f}>\psi_{i}>
$$

c : Representation of planes by their poles and determination of the line of intersection of the planes by the pole of the great clrele which passes through their poles.

d: Preliminary evaluation of the stabllity of a $50^{\circ}$ slope in a rock mass with 4 sets of structural discontinuities.

Figura VI.4.5.2. Análise de rupturas planas em projeção estereográfica (Hoek e Bray, 1997) 
Embora a figura apresentada seja de certa forma auto-explicativa, podemos frisar os seguintes aspectos:

Caso a: Os planos de descontinuidades $\mathrm{A}$ e $\mathrm{B}$, são representados pelas suas projeções ciclográficas e se interceptam segundo uma reta ("plunge"), a qual determina a direção do escorregamento.

A condição de escorregamento é que o "plunge" da reta-interseç̧ão, seja menor que o ângulo de inclinação do talude, medido no rumo do escorregamento.

Caso b: É uma reprodução do caso a , no qual é introduzido o ângulo de atrito interno do talude, representado por um círculo. A condição de ruptura está representada na projeção, pelo posicionamento da retaintersecção $\mathrm{AB}$, dentro da zona achurada.

Caso c: Corresponde a uma outra representação do caso $\underline{b}$. Os planos $\mathrm{A}$ e $\mathrm{B}$, estão neste caso representados pelos seus polos. Existe um plano que contem esses dois polos e, a $90^{\circ}$ do mesmo, está a reta-intersecção $A B$, dentro da zona instável achurada, reproduzindo o caso anterior.

Caso d: Neste caso estão representadas as concentrações de polos de 4 famílias de descontinuidades As concentrações máximas, definem os polos dos planos médios 1, 2, 3 e 4 dessas famílias. As retas-intersecções 12 e 23, dentro da zona instável achurada, representam condições de ruptura, não havendo risco para a interseção 13 , nem para as interseções que envolvem o plano 4. 


\section{CAPÍTULO VII}

\section{CONDICIONANTES LOCAIS DE ESTABILIDADE}

\section{VII.1. PERFIL DE ALTERAÇÃO E PARÂMETROS DE ESTABILIDADE}

Um modelo do perfil de alteração de rochas metamórficas em regióes serranas, foi elaborado por PASTORE, 1995, conforme apresentado na Figura VII.1.1.

O modelo, com algumas ressalvas, pode ser aplicado à Serra de Cubatão, onde os horizontes nem sempre estão bem individualizados, sendo suas espesssuras variáveis, alem dos valores indicados. Na Figura VII.1.2., apresentamos um perfil de alteração numa das seções das fundações de um viaduto da Rodovia dos Imigrantes, elaborada de acordo com uma sistemática estabelecida para o acompanhamento geológico-geotécnico da obra.

Devemos entender coluvião, como um termo genérico para designar os solos $e$ materiais transportados por gravidade que recobrem as encostas e se encontram sujeitos a mecanismos de movimentação geralmente por rastejo. Nessa concepção, englobam tanto os solos coluviais delgados e cobrindo grandes extensões, aos quais já nos temos referido algumas vezes, como os tálus bem mais espessos, confinados às depressões do embasamento e sopés de encostas.

O termo solo coluvionar é usado por alguns autores, correlacionado com coluvião. Em alguns relatórios técnicos, entretanto, temos encontramos solo coluvionar e solo coluvial sendo usados indistintamente.

Os solos coluviais comumente tem espessura da ordem de 0,5 a $1,5 \mathrm{~m}$ como indicado na figura, podendo atingir localmente 4 a $5 \mathrm{~m}$. Conforme já foi comentado anteriormente, eles sofrem periodicamente escorregamentos em épocas chuvosas, podendo produzir "corridas de lama" e provocando o aparecimento de extensas cicatrizes na vegetação. As argilas lateríticas são de ocorrência bem restrita na área.

Os tálus tem grande importância do ponto de vista da estabilidade, por constituirem grandes massas localizadas e depositadas em condições frequentemente instáveis. Formam zonas bem marcadas no mapa geológico (Figura III.1.1.1.), algumas das quais tem sido alvo de ocupações humanas desordenadas através dos anos, assunto que será comentado no Capítulo VIII. Suas espessuras são bastante variáveis, podendo atingir valores máximos superiores a $22 \mathrm{~m}$, conforme observado nas escavações para as fundações do viaduto VA-20, da Rodovia dos Imigrantes, na transposição do Rio Cubatão (MACHADO FILHO, 1974). 


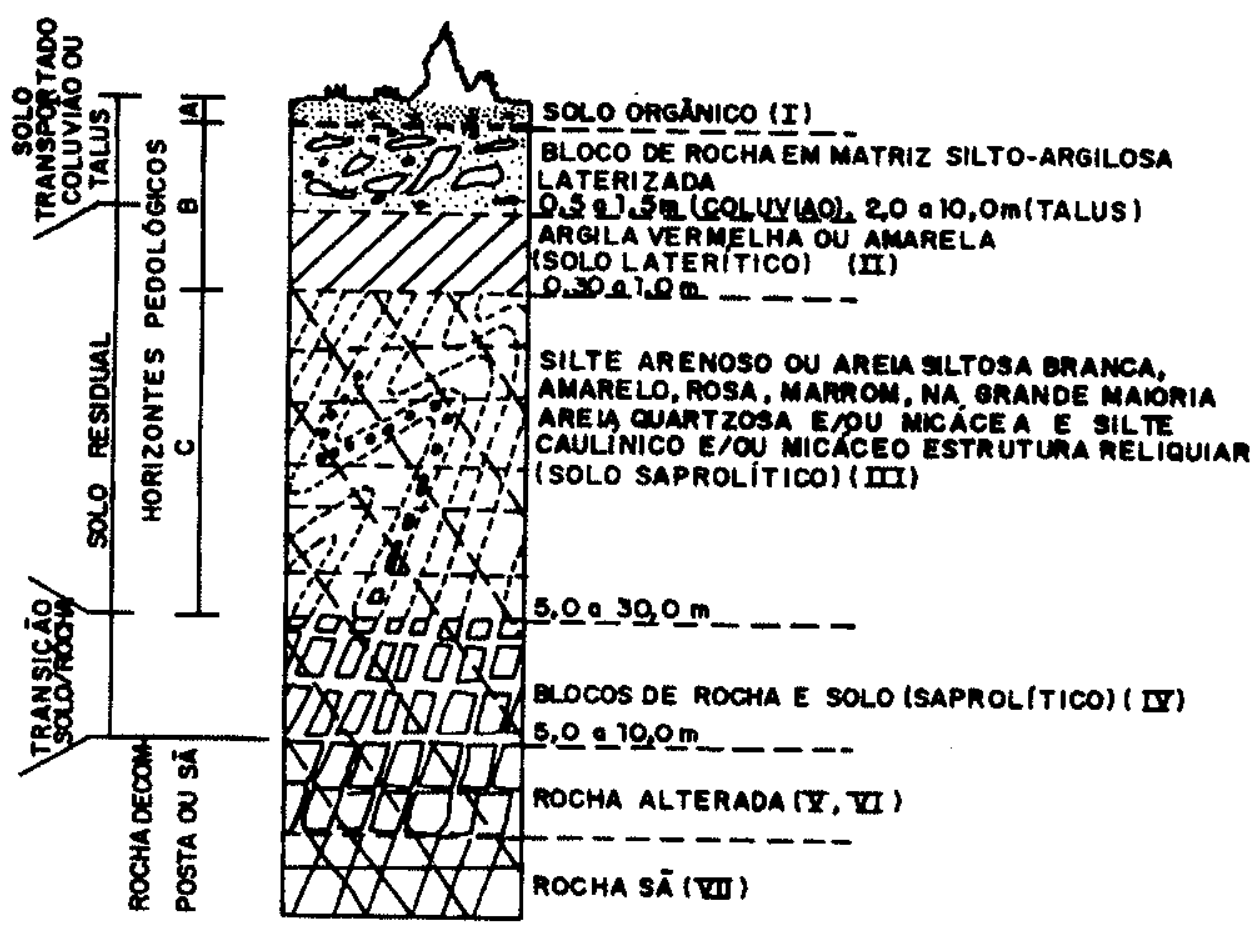

Figura VII.1.1. Perfil de alteração típico de rochas metamórficas em região de serra (Pastore, 1995)

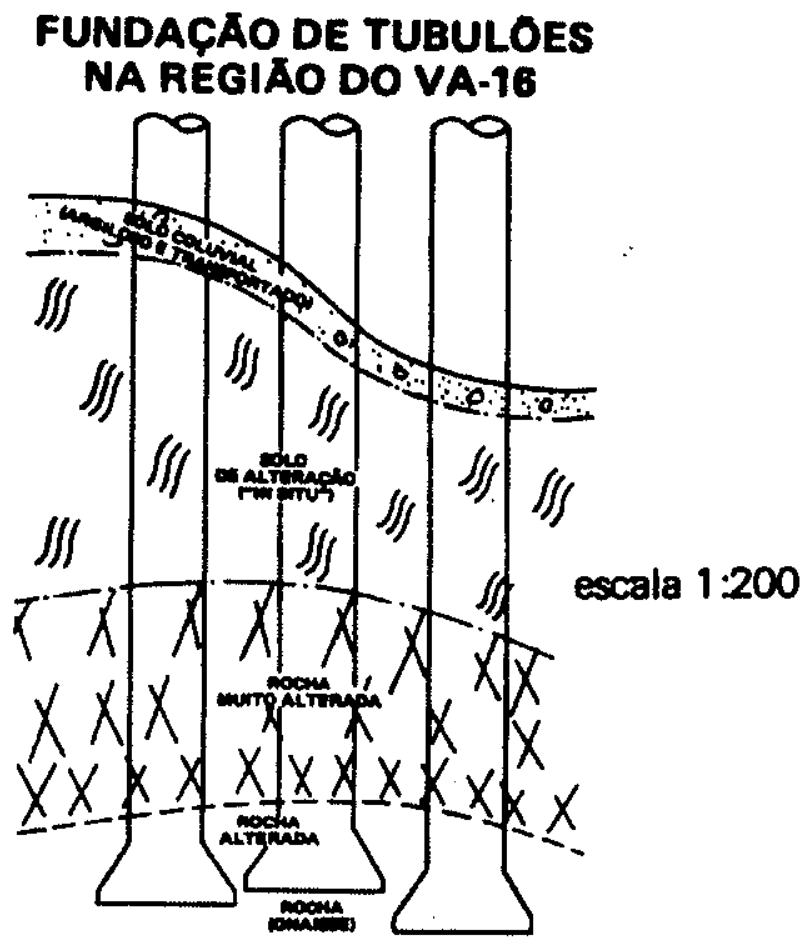

Figura VII.1.2. Perfil de alteração na região do viaduto VA-16 da Rodovia dos Imigrantes (Machado Filho, 1974) 
O solo saprolítico, prevalece entre os solos residuais, tendo como característica a preservação de estruturas reliquiares (chamadas macroestruturas de solos por alguns autores), do tipo xistosidades, bandamentos e gnaissificação. Sua espessura é bastante grande nas cotas mais elevadas junto à borda do Planalto Paulistano, onde atinge várias dezenas de metros, decrescendo progressivamente à medida que se desce a escarpa. Abaixo da cota $300 \mathrm{~m}$, sua espessura está geralmente reduzida a alguns metros, sendo comum o afloramento de rocha sã nos talvegues e à meia encosta.

O horizonte de rocha alterada, geralmente é um saprolito com estruturas geológicas marcantes (xistosidade, bandamentos, gnaissificações, clivagens. etc), possuindo espessuras muito variáveis, geralmente superiores a $5 \mathrm{~m}$, podendo atingir mais de $20 \mathrm{~m}$, conforme constatado nas escavações das fundaçóes de viadutos no trecho da serra. Como regra geral, a sua espessura decresce com a diminuição da altitude, tal como acontece para o solo saprolítico.

Os parâmetros de estabilidade c e $\phi$, foram pesquisados pelo IPT e relatados por WOLLE (1988), para o solo coluvionar e solo saprolítico. A pesquisa constou de amostragem e ensaios de 17 blocos indeformados, extraidos de encostas das regióes dos túneis TA-6 e TA-7, da Rodovia dos Imigrantes e de tálus de região vizinha. Constatou que existe grande variabilidade nos resultados e que ocorre nítida perda de resistência dos solos com a saturação (Tabela VII.1.1). Considerando todos os pontos obtidos nos ensaios citados, foram admitidos os valores médios, conforme Tabela VII.1.2. Como valores médios dos pesos específicos naturais, foram adotados $14,3 \mathrm{kN} / \mathrm{m}^{3}$ para o solo coluvionar e 18,0 $\mathrm{kN} / \mathrm{m}^{3}$ para o solo saprolítico. Em nova campanha de ensaios, posteriormente, nas encostas dos túneis TA-4 e TA-5 da mesma rodovia, o IPT encontrou valores bastante semelhantes aos acima mencionados.

Para os horizontes de rocha alterada e rocha sã, os parâmetros variam em função do local considerado e não temos dados precisos para apresentar. Sabemos que, para esses horizontes, a coesão varia basicamente em função do grau de fraturamento e, por essa razão, em certos casos, deve ser considerada bastante baixa ou próxima de zero. Quanto ao ângulo de atrito interno, embora menos sensivel que a coesão, tambem varia com o fraturamento da rocha. Geralmente pode ser considerado entre $35^{\circ}$ e $45^{\circ}$. 
Tabela VII.1.1. Resultados de ensaios de cisalhamento direto em amostras das encostas próximas aos túneis TA-6 e TA-7, da Rodovia dos Imigrantes (IPT, 1976, apud Wolle, 1988)

\begin{tabular}{|c|c|c|c|c|c|c|c|c|}
\hline SOLO & ENSAIOS & COM & UMIDADE & NATURAL & \multicolumn{2}{|r|}{ ENSAIOS } & \multicolumn{2}{|l|}{ INUNDADOS } \\
\hline ENSAIADO & $\begin{array}{l}\text { Cmin } \\
(\mathrm{kPa})\end{array}$ & $\begin{array}{l}\text { Cmax } \\
(\mathrm{kPa})\end{array}$ & $\oint_{\min }$ & $\phi_{\max }$ & $\begin{array}{l}\mathrm{C}^{\prime} \min \\
(\mathrm{kPa})\end{array}$ & $\begin{array}{l}C^{\prime} \max \\
(k \mathrm{kA})\end{array}$ & $\phi^{\prime} \min$ & $\phi^{\prime \max }$ \\
\hline $\begin{array}{c}\text { SOLO } \\
\text { COLUVIONAR }\end{array}$ & $\begin{array}{c}2,0 \\
\left(P / \phi=29^{\circ}\right)\end{array}$ & $\begin{array}{c}14,0 \\
\left(\mathrm{P} / \phi=30^{\circ}\right)\end{array}$ & $\begin{array}{c}29^{\circ} \\
(p / C=2)\end{array}$ & $\begin{array}{c}40^{\circ} \\
(p / C=10)\end{array}$ & $\begin{array}{c}0 \\
\left(p / \phi=39^{\circ}\right)\end{array}$ & $\begin{array}{c}6,0 \\
\left(p / \phi=36^{\circ}\right)\end{array}$ & $\begin{array}{c}26^{\circ} \\
\left(p / C^{\prime}=4\right)\end{array}$ & $\begin{array}{c}40^{\circ} \\
\left(p / C^{\prime}=0\right)\end{array}$ \\
\hline $\begin{array}{l}\text { SOLO SA- } \\
\text { PROLÍTICO }\end{array}$ & $\begin{array}{c}8,0 \\
\left(p / \phi=45^{\circ}\right)\end{array}$ & $\begin{array}{c}50,0 \\
\left(p / \phi=32^{\circ}\right)\end{array}$ & $\begin{array}{c}22 \\
\mathrm{p} / \mathrm{C}=17)\end{array}$ & $\begin{array}{c}45 \\
(p / C=20)\end{array}$ & $\begin{array}{c}0 \\
\left(p / \phi=34^{\circ}\right)\end{array}$ & $\begin{array}{c}30,0 \\
\left(p / \phi=32^{\circ}\right)\end{array}$ & $\begin{array}{c}22 \\
\left(p / C^{\prime} 17\right)\end{array}$ & $\begin{array}{c}45 \\
\left(p / C^{\prime}=0\right)\end{array}$ \\
\hline
\end{tabular}

Tabela VII.1.2. Parâmetros médios de resistência ao cisalhamento dos solos (IPT, 1976, apud Wolle, 1988)

\begin{tabular}{|c|c|c|c|c|}
\hline \multirow{2}{*}{$\begin{array}{c}\text { TIPO DE } \\
\text { SOLO }\end{array}$} & \multicolumn{2}{|c|}{$\begin{array}{r}\text { SOLO COM UMIDADE } \\
\text { NATURAL }\end{array}$} & \multicolumn{2}{|c|}{ SOLO INUNDADDO } \\
\cline { 2 - 5 } & $\mathrm{C}(\mathrm{kPa})$ & $\phi$ & $\mathrm{C}^{\prime}(\mathrm{kPa})$ & $\phi$ \\
\hline $\begin{array}{c}\text { SOLO } \\
\text { COLUVIONAR }\end{array}$ & 6,0 & $34^{\circ}$ & 1,0 & $34^{\circ}$ \\
\hline $\begin{array}{c}\text { SOLO } \\
\text { SAPROLITITCO }\end{array}$ & 12,0 & $45^{\circ}$ & 4,0 & $39^{\circ}$ \\
\hline
\end{tabular}




\section{VII.2. COMPARTIMENTAÇÃO DA ÁREA}

Existe uma compartimentação natural da área da pesquisa, determinada pela geomorfologia, conforme discutimos no Capítulo IV.

São bastante nítidas as diferenças de relevo, padrão de drenagem, vegetação, tipos de solos, perfil de alteração, etc, entre as províncias do Planalto Paulistano, Serra de Cubatão e Planície Costeira.

Essas diferenças, resultam em comportamentos tambem diferentes quanto à estabilidade dos taludes e encostas que, no trecho serrano, que constitue objeto principal de nosso trabalho, apresentam-se em condições precárias, quando não críticas. É nesse trecho que ocorrem de forma acentuada, os movimentos de massa, representados tanto pelos escorregamentos generalizados e/ou localizados, como pelos movimentos lentos de rastejo, já anteriormente abordados.

Baseados no estudo de distribuição dos lineamentos estruturais, visíveis em fotografias aéreas e imagens de satélite, procuramos estabelecer possiveis domínios diferenciados, conforme analisado em III.2.

Inicialmente, estudamos essa distribuição em duas das províncias geomorfológicas mencionadas, as quais apresentam visualmente, padróes distintos - planalto e serra. Quanto à planície, não apresenta essas estruturas visíveis.

Comparando os resultados dos gráficos de distribuição de frequências dos lineamentos no planalto e na serra, verificamos, com alguma surpresa, que eram bastante semelhantes (Figuras III.2.2.2. e III.2.2.3.).

Fizemos outras tentativas, com base no padrão aparente dos lineamentos, com resultados semelhantes.

Uma das tentativas entretanto, se mostrou interessante, resultando na separação nas áreas A e B, delimitadas no mapa da Figura III.2.2.1. (gráficos nas Figuras III.2.2.4. e III.2.2.5.).

$\mathrm{Na}$ área $\mathrm{A}$, a direção principal dos fotolineamentos é $\mathrm{N} 55^{\circ}$ (concordante com as grandes estruturas regionais) e a direção secundária é $\mathrm{N} 145^{\circ}$. Na área $\mathrm{B}$, ocorre uma inversão, sendo a direção principal $\mathrm{N} 140^{\circ}$ e a secundária $\mathrm{N} 55^{\circ}$.

Assim sendo, na área $\mathrm{A}$, as estruturas principais acompanham a linha geral da escarpa, interceptando a direção preferencial das drenagens, enquanto na área B, as estruturas principais são normais à linha da escarpa e concordantes com a direção preferencial das drenagens. 
Do ponto de vista da influência das drenagens na estabilidade das encostas, significa que as áreas $\underline{A}$ e $\underline{B}$, possuem, condições diferenciadas.

$\mathrm{Na}$ área $\mathrm{A}$, a tendência é a pressão hidráulica, incidindo diretamente sobre a face do plano principal de descontinuidades, favorecer seu deslocamento, instabilizando pontos do maciço. Já na área B, a tendência é o agravamento da ação erosiva com ravinamentos ao longo das drenagens principais, entalhadas segundo a linha de maior declive da escarpa.

A delimitação das área $\mathrm{A}$ e $\mathrm{B}$, orientou a seleção dos 5 pontos escolhidos para detalhamento de campo: 2 locais na Área A e 3 locais na Área B, cujos resultados foram apresentados nas Figuras III.2.3.1 a III.2.3.5. ; Figuras III.2.4.1. a III.2.4.5.; Tabela III.2.4.1. Esses resultados foram analisados no capítulo correspondente.

Verifica-se que, cada caso, apresenta peculiaridades locais, indicando a necessidade de estudo detalhado de cada situação nas análises de estabilidade.

De modo geral entretanto, os levantamentos indicaram (com excessão do ponto B1), uma direção marcante de descontinuidades entre $\mathrm{N} 45^{\circ}$ a $\mathrm{N} 60^{\circ}$, mergulhando $50^{\circ}$ a $85^{\circ}$ para $\mathrm{NW}$, com forte condicionamento da foliação. 


\section{VII.3. MODELOS DE INSTABILIZAÇÃO}

Os escorregamentos mais comuns, são os translacionais, afetando os solos coluviais. Ocorrem tanto isoladamente, como de forma generalizada nos anos de chuvas intensas e concentradas.

A Figura VII.3.1., ilustra um desses escorregamentos, podendo ser tomada como um modelo genérico para os mesmos.

Conforme já mencionamos, são de espessura delgada, afetando grandes extensões e provocando cicatrizes lineares na paisagem (Fotografia VII.3.1.).

O mecanismo de instabilização mais comum nesse caso, pode ser descrito resumidamente da seguinte maneira:

- O solo coluvial, vai perdendo resistência ao cisalhamento na época chuvosa, à medida que a saturação d'água provoca a diminuição de sua coesão aparente;

- Alcançado o limite de ruptura, inicia-se o deslocamento da massa ao longo da superfície de contacto com o solo saprolítico ou o saprólito, que lhe são subjacentes e tem maior resistência;

- No início dessa movimentação, a massa pode apresentar um aspecto de "estufamento", conforme já tivemos oportunidade de observar visualmente no campo;

- O deslocamento da massa provoca então o aparecimento de fendas de tração na sua parte superior, as quais vão irromper na superfície do talude, no ponto de menor resistência.

Frequentemente, temos encontrado partes do substrato saprolítico, arrastadas durante o escorregamento (Fotografia VII.3.2.).

Já mencionamos que movimentos lentos de rastejo, instabilizam tanto os horizontes superficiais como os horizontes rochosos mais profundos, podendo atingir dezenas de metros de profundidade.

Entretanto, não temos um modelo geral para apresentar, já que as características são muito variadas, dependendo de cada situação.

Nos solos superficiais e no tálus, a massa movimentada, lenta e contínuamente, pode se comportar plasticamente, não havendo superfície de ruptura definida. 
As rupturas planares, condicionadas por descontinuidades, constituem casos localizados que afetaram vários taludes rodoviários, tanto na fase construtiva, como na fase operacional, nas Via Anchieta, Caminho do Mar e estradas de serviço do sistema Anchieta-Imigrantes.

Cada caso, merece um estudo especial, com cuidadoso levantamento das descontinuidades, estabelecendo os planos preponderantes no mecanismo de ruptura. Conforme abordado anteriormente, quando os planos das descontinuidades tem mergulho superior ao ângulo de atrito do material $e$ interceptam a superfície do talude tangencialmente, estão estabelecidas as condições para ocorrência de ruptura.

Por vezes, o maciço rochoso pode estar extremamente fraturado, com planos em várias direções, resultando numa distribuição aproximadamente homogênea das descontinuidades. Escorregamentos nesse caso, assemelham-se ao tipo rotacional.

Escorregamentos de tálus, por vezes são translacionais, assemelhando-se aos solos coluviais e por vezes, obedecem a um padrão rotacional, como o ocorrido na Cota 95 da Via Anchieta, que será comentado posteriormente.

Não existe um padrão aplicável a todos os depósitos de tálus, os quais diferem pela espessura, composição, inclinação saturação, etc. Sabe-se entretanto, que a intervenção humana, realizando cortes, ou criando sobrecargas nos tálus, em várias oportunidades provocou sua ruptura. Exemplos são conhecidos na Via Anchieta (Cotas 500, 400, 200, 95) e na estrada de serviço da Rodovia dos Imigrantes (regiões dos VA-19, VA-20 e VA-21). 


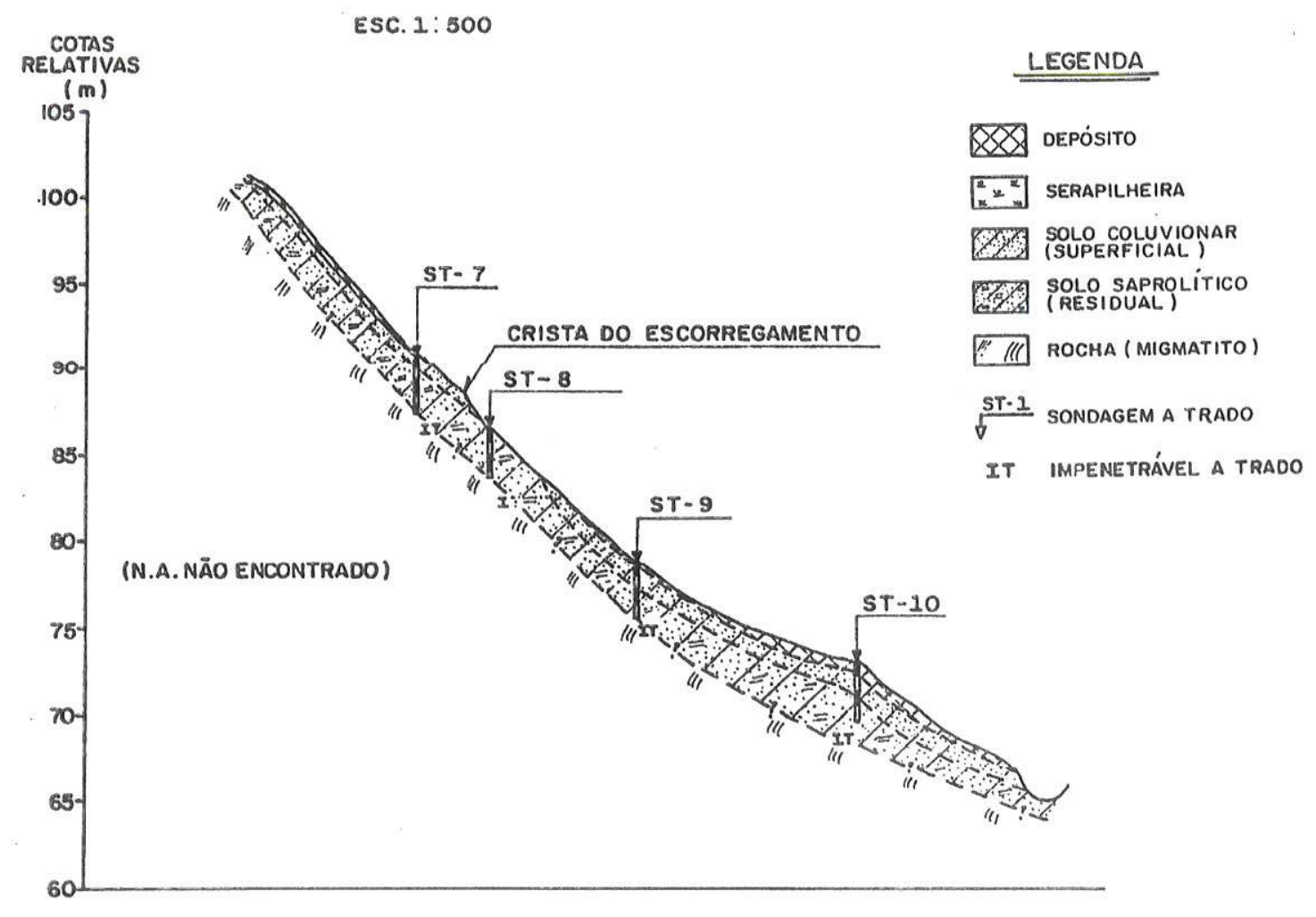

Figura VIl.3.1. Instabilização em solo coluvionar

(Wolle, 1988)

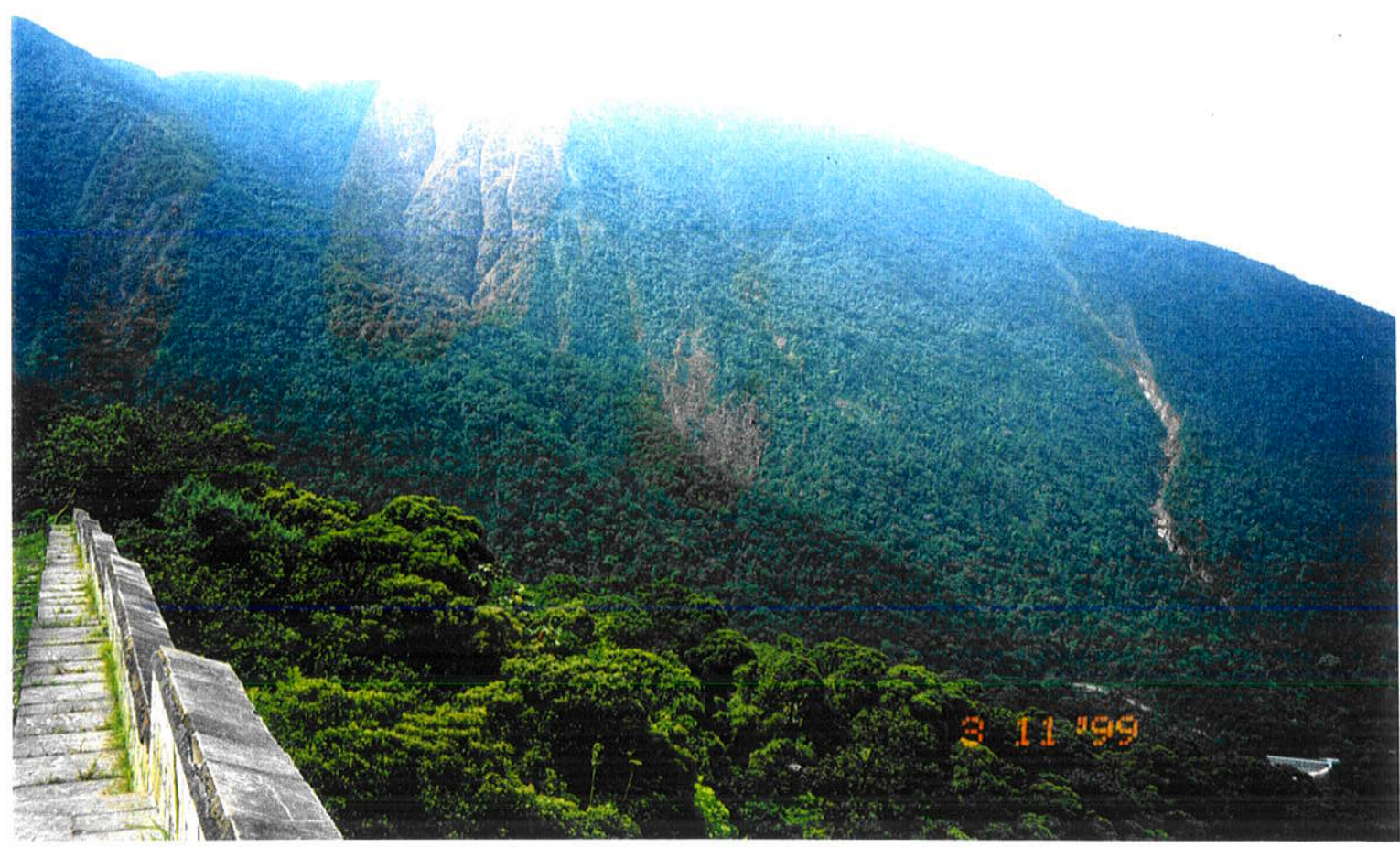

Fotografia VII.3.1. Escorregamentos translacionais na Serra de Cubatão. 


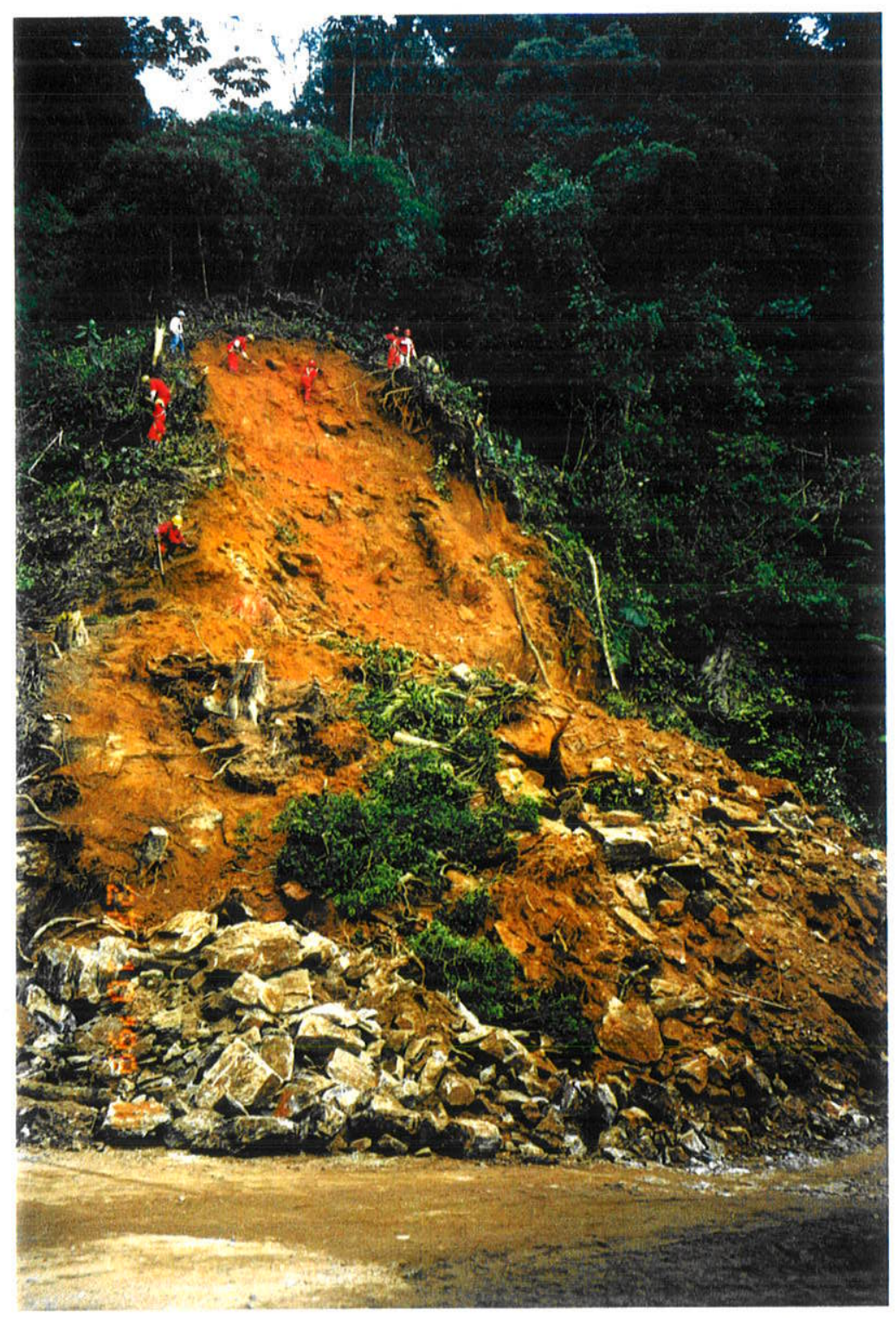

Fotografia VII.3.2. Escorregamento de solo coluvial arrastando o substrato saprolítico 


\section{VII.4. TIPOS DE TRATAMENTOS E CONTENÇÕES UTILIZADOS}

\section{VII.4.1. Considerações Gerais e Principais Tipos}

A área da pesquisa é cortada por algumas rodovias e uma ferrovia, as quais, desde as épocas de suas construções, sofreram problemas com instabilizações de encostas, tendo que adotar diversas soluções para os tratamentos e contenções.

Sendo o trecho serrano o que apresenta condições mais problemáticas quanto à estabilidade é nele que se encontram a quase totalidade das obras de contenção, ao longo da ferrovia ex-FEPASA e das rodovias Anchieta, Imigrantes e Caminho do Mar.

Os tipos de tratamentos utilizados, variaram bastante ao longo do tempo, refletindo a tecnologia disponivel em cada época. Verifica-se, por exemplo, que no Caminho do Mar, bem como em locais da ferrovia e da Via Anchieta, foram executadas obras mais artesanais, como muros de pedras da região, procurando uma conformação com a paisagem local. Ainda hoje, muitas dessas obras apresentam-se em excelente estado, passado quase um século de sua execução.

A Rodovia dos Imigrantes, por ser mais recente e tambem devido às características arrojadas de seu projeto, incorporou novas tecnologias na sua construção, incluindo as relativas ao tratamento e contenção de encostas e taludes.

"Convem lembrar, nessa altura das ponderações, que são os cuidados com a manutenção das obras mais simples de drenagem superficial (canaletas de drenagem, bueiros e descidas d'água), que determinam sua boa performance $e$ durabilidade, bem como das demais obras (muros e cortinas, revestimentos superficiais, tratamentos vegetais, etc.), as quais não devem receber o impacto direto das enxurradas durante as chuvas".

A maioria das técnicas utilizadas nos tratamentos e contenções, podem ser englobadas nos tipos principais seguintes:

- Muros atirantados

- Estacas-raiz

- Gabião e "crib-wall

- Anéis de proteção em viadutos

- Muros de concreto

- Muros de pedra 
- Gunita e concreto projetado

- Chumbadores

- Revestimento betuminoso

- Canaletas, bueiros e descidas d'água

- Drenos profundos

- Tratamento vegetal

Obras executadas em vários locais, exigiram a utilização conjunta de dois ou mais dos tipos citados, tendo em vista as características do projeto. Em todos os casos, verificou-se a importância fundamental da drenagem superficial, já que a região possui alto índice pluviométrico, havendo ao final de cada obra, recomendações para a reconstituição da vegetação afetada.

Os quatro primeiros tipos citados, serão tratados na sequência, em itens separados, por se tratarem de obras geralmente de grande porte, que foram utilizadas na solução de problemas mais graves e/ou complexos.

Quanto aos demais tipos, serão descritos de forma sucinta, a seguir.

Propositadamente, evitaremos detalhar a metodologia executiva dos vários tipos abordados, por fugir ao escopo deste trabalho.

As fotografias apresentadas, se não houver menção da fonte, foram tiradas pelo autor, em diferentes datas, a partir de 1974.

Muros de concreto.

Foram utilizado como arrimo em cortes e alguns aterros, em locais da Via Anchieta, funcionando como "muros de gravidade", que como sabemos é uma estrutura rígida que atua pelo próprio peso.

Nas estradas de serviço da Rodovia dos Imigrantes, foram empregados em vários cortes em material rochoso fraturado, com a função de arrimo e de revestimento, evitando seu desconfinamento e relaxamento gradual, o que levaria à ruptura (Fotografia VII.4.1.1.). Na fotografia, alem do muro de concreto no talude interno, podemos observar um muro atirantado na parte à juzante, suportando a plataforma estradal.

\section{Muros de pedra}

Essas constuções, bastante artesanais, foram executadas através de trabalhos demorados e cuidadosos, utilizando pedras da região.

São encontrados especialmente no Caminho do Mar, inaugurado em 1913 e em alguns pontos da Via Anchieta, inaugurada em 1947. Podem funcionar como 
muros de arrimo de encostas e taludes, ou como muros laterais de galerias $e$ escadas hidráulica, conforme mostrado na Fotografia VII.4.1.2.

\section{Gunita e concreto projetado.}

Esse tipo de revestimento é aplicado através de bombas, por jateamento com alta pressão, formando uma camada superficial muito resistente, perfeitamente aderente à parede da encosta, acompanhando todas as suas irregularidades, preenchendo pequenas cavidades e vazios. O termo concreto projetado é mais genérico, sendo gunita utilizado para o concreto mais flúido, com agregado fino. (Fotografia VII.4.1.3).

O concreto projetado tem importante utilização como contenção provisória de taludes subterrâneos (tambem chamado suporte temporário), sendo aplicado imediatamente após a escavação de uma seção de túnel, evitando a relaxação da rocha. Esse método foi desenvolvido pelos austríacos na metade do século, sendo utilizado na Rodovia dos Imigrantes.

\section{Chumbadores.}

Esse tipo foi usado em certas zonas superficialmente instáveis, geralmente associado à colocação de tela protetora de aço galvanizado, para evitar a queda de blocos instáveis e material solto sobre a estrada (Fotografia VII.4.1.4.).

Os chumbadores são constituidos de vergalhões de aço, com diâmetro variável entre $1 / 2$ e $3 / 4$ de polegada e comprimentos de 2 a $5 \mathrm{~m}$. São providos de uma rosca na sua extremidade externa, junto ao talude, onde se adapta uma placa ou cabeça, a qual é pressionada pelo rosqueamento de uma porca. Funciona com um tirante de pequena capacidade de carga

\section{Retaludamento.}

Foi usado em taludes de solos ou tálus, que por se mostrarem instáveis ou já terem se rompido, necessitaram de modificações na sua geometria.

Um exemplo desse trabalho foi executado no tálus na cota 95 da Via Anchieta, onde ocorreu ruptura do talude provocando alteamento da pista. A solução, englobando retaludamento, suavizou a inclinação do corte, introduzindo novas banquetas e bermas de equilibrio. Esse caso será tratado posteriormente, ao discutirmos os "Bairros-Cota".

\section{Revestimento betuminoso.}

Como o nome indica, constitue a aplicação de uma camada superficial de material betuminoso, visando a impermeabilização do talude contra as águas de infiltração das chuvas.

Esse tipo de tratamento, que tambem será exemplificado posteriormente, exige manutenção periódica, devendo estar sempre associado a obras de drenagem superficial e profunda. 


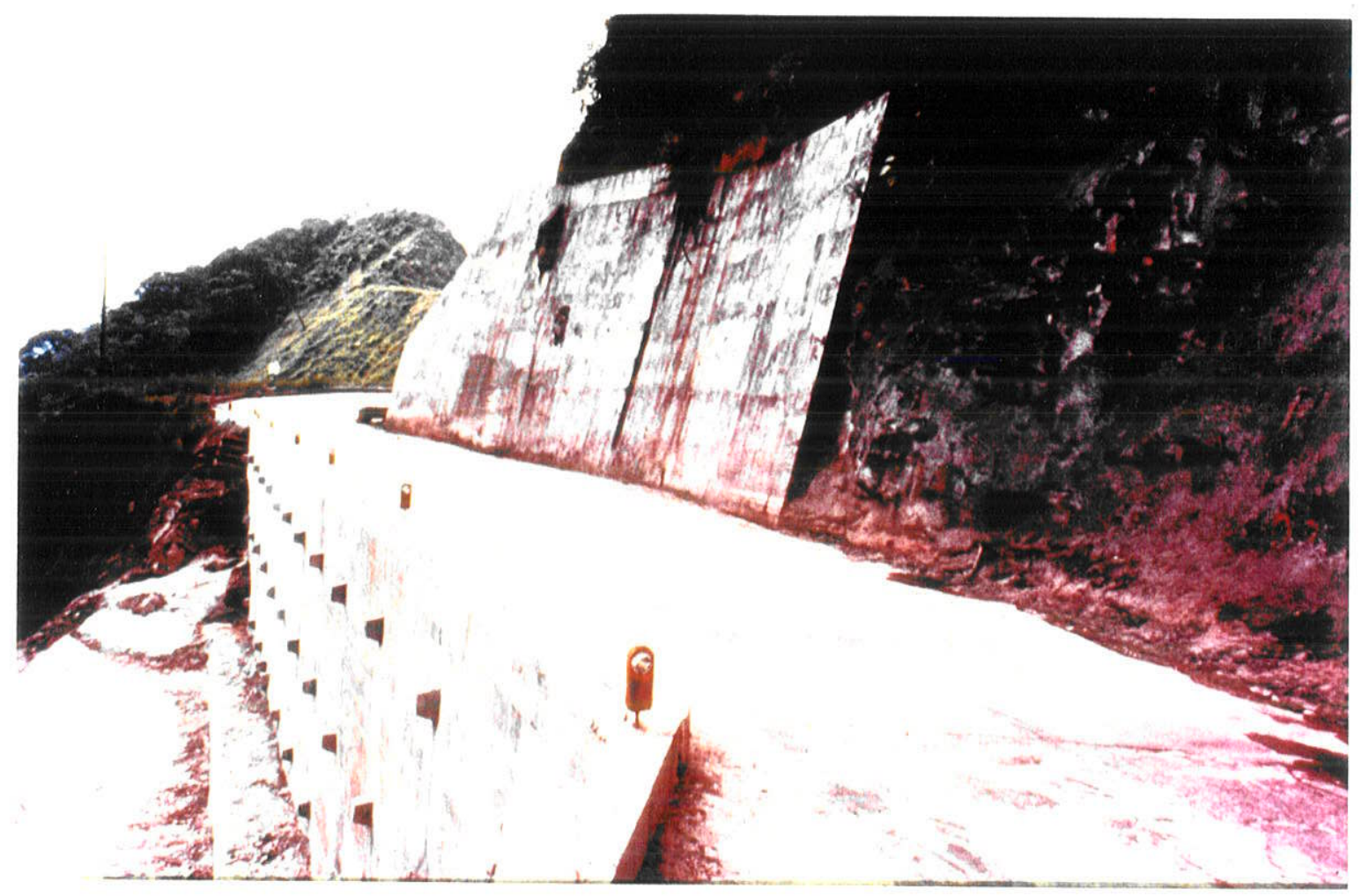

Fotografia VII.4.1.1. Muro de concreto em corte da estrada de serviço da Rodovia dos Imigrantes. A juzante, muro atirantado

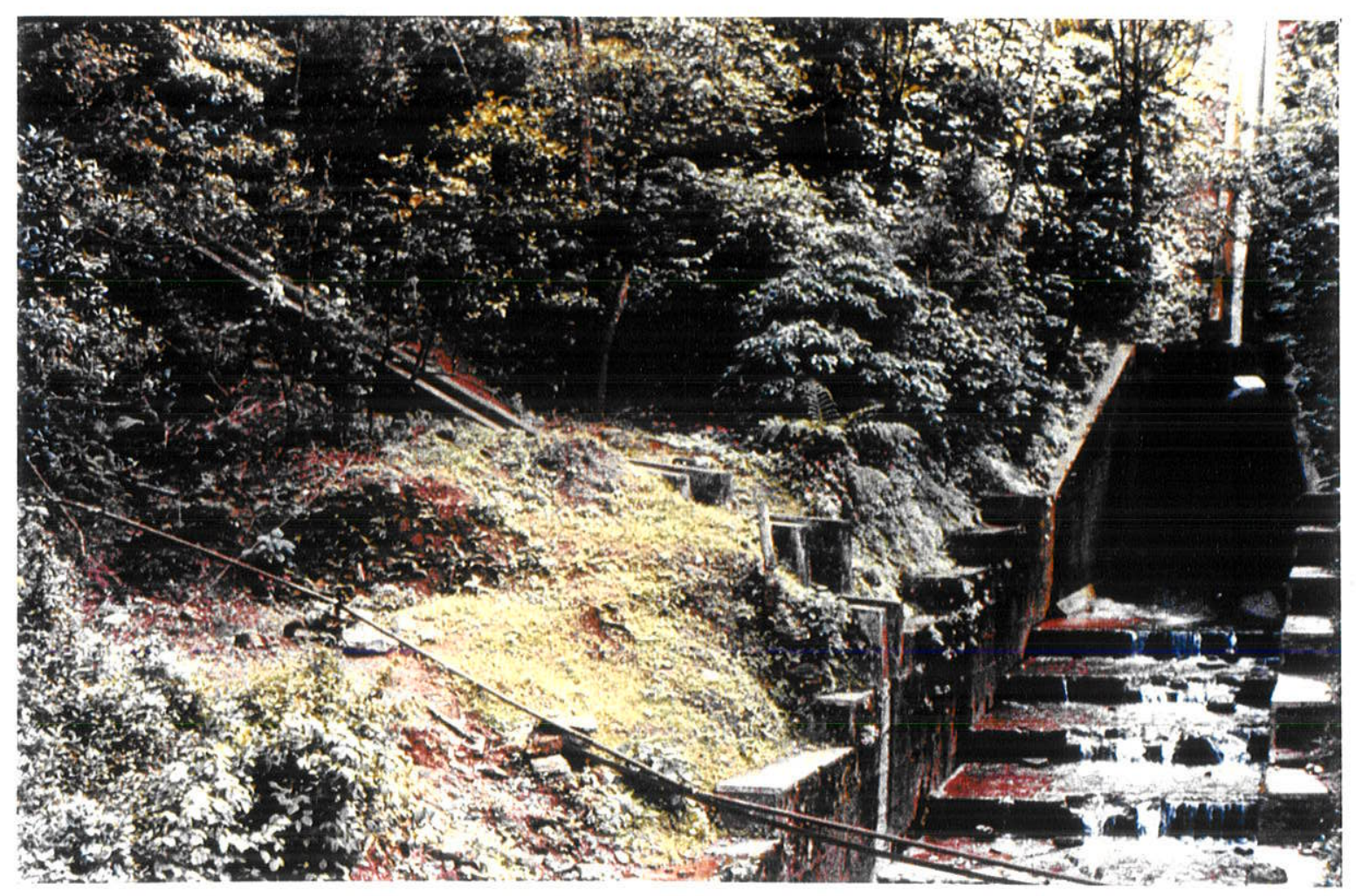

Fotografia VII.4.1.2. Muros de pedra fazendo parte de galeria e escada hidráulica 


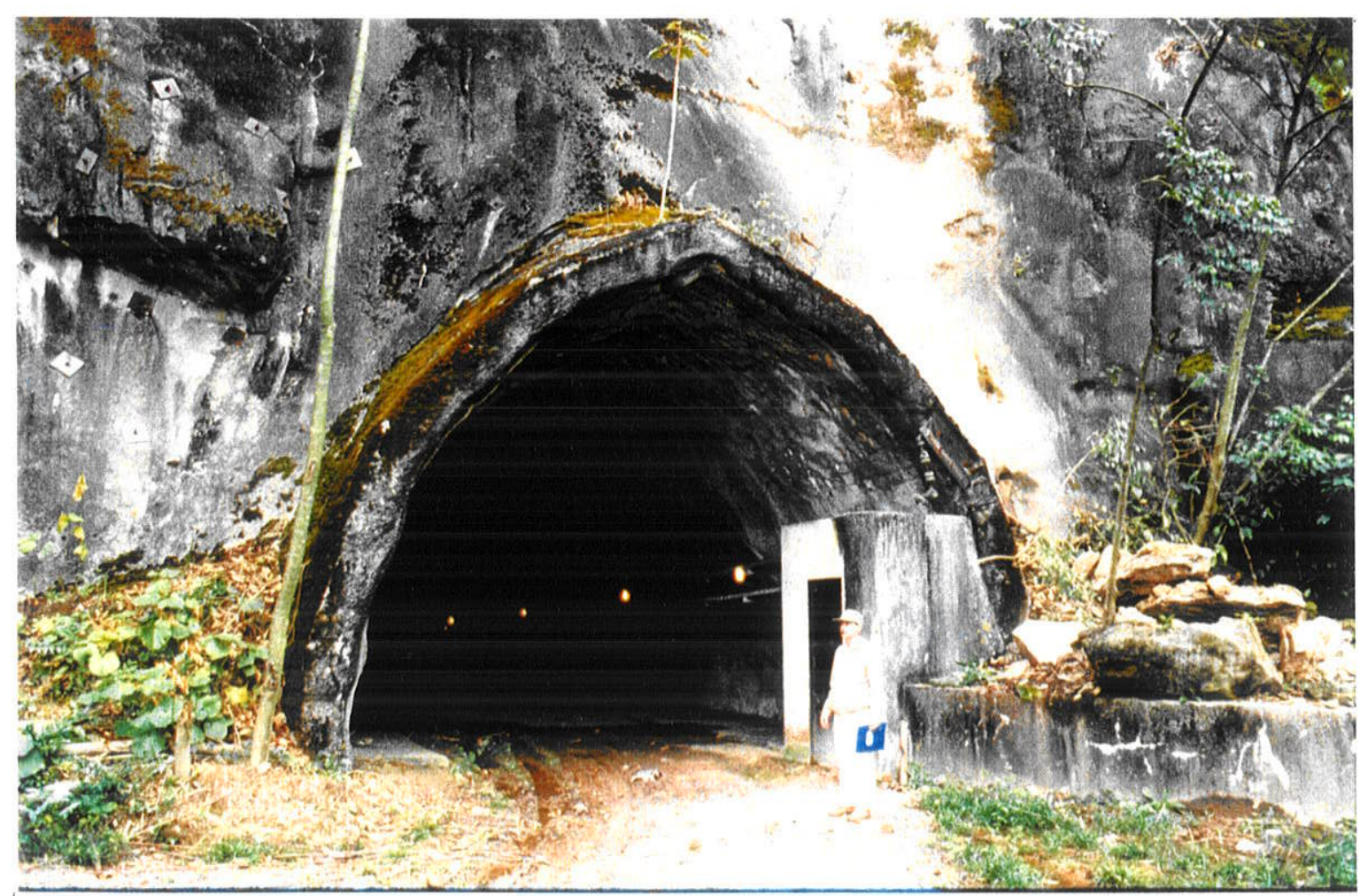

Fotografia VII.4.1.3. Concreto projetado em zona de emboque de túnel. Janela de serviço do TA-9, Rodovia dos Imigrantes

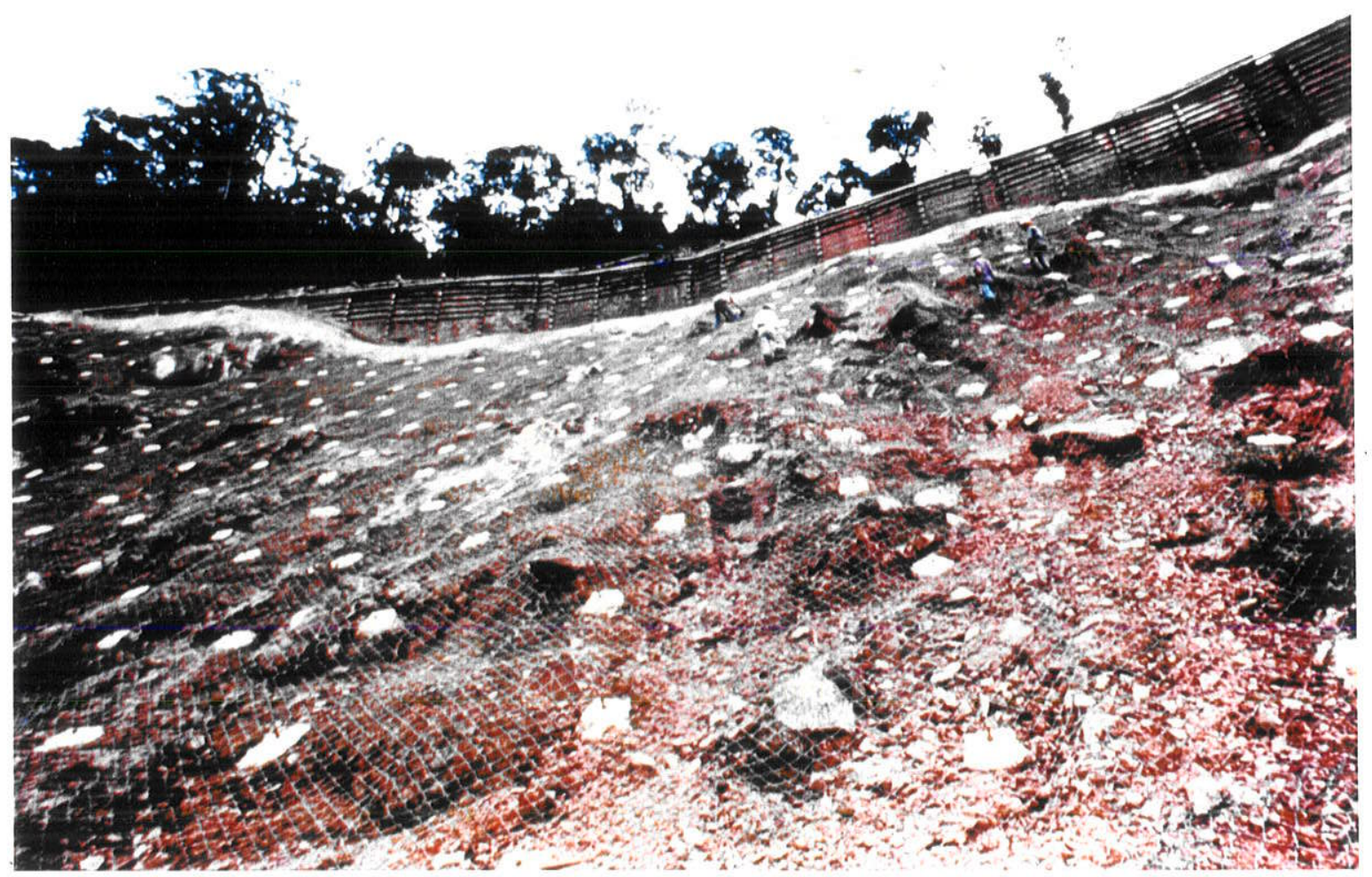

Fotografia VII.4.1.4. Encosta protegida com chumbadores e tela metálica 
Canaletas, bueiros e descidas d'áqua.

São obras de drenagem superficial de uso corrente, que juntamente com galerias, caixas de captação e escadas hidráulicas, são fundamentais para o disciplinamento do escoamento das águas pluviais (Fotografia VII.4.1.5.).

Como já foi mencionado anteriormente, a sua boa manutenção evita a ocorrência de concentrações de água, as quais podem acarretar erosões localizadas dando início a processos de instabilização.

\section{Drenos profundos.}

Foram largamente empregados, especialmente em zonas de tálus, com o objetivo principal de aliviar as pressóes capilares resultantes da existência de aquíferos confinados (casos da cota 500 e 400 da Via Anchieta e vários pontos da Rodovia dos Imigrantes). Suas vazões variam muito, dependendo do local, podendo atingir alguns litros por minuto (Fotografia VII.4.1.6.). São construidos com tubos perfurados de PVC com diâmetro de $2 \frac{1}{2}$ a 4 polegadas, envolvidos por tela de nylon ou manta Bidim, sendo o comprimento muito variável, geralmente entre $12 \mathrm{e}$ $25 \mathrm{~m}$, mas em alguns casos alcançando mais de $35 \mathrm{~m}$.

\section{Tratamentos vegetais.}

São empregados via de regra como complementação e acabamento de um projeto de contenção, reconstituindo a flora afetada durante a execução da obra.

A vegetação, como já foi discutido anteriormente, possue um papel efetivo no travamento dos solos e na distribuição das águas de infiltração.

Uma modalidade interessante de tratamento vegetal,. conhecida como "cordóes vegetais", foi utilizada em encostas de solos, como ilustrado nas Fotografias VII.4.1.7. e VII.4.1.8. Os cordões, constituidos de bambu, formam linhas paralelas proeminentes, acompanhando as curvas de nível do terreno, entre as quais a vegetação rasteira tem melhores condições para se fixar. 


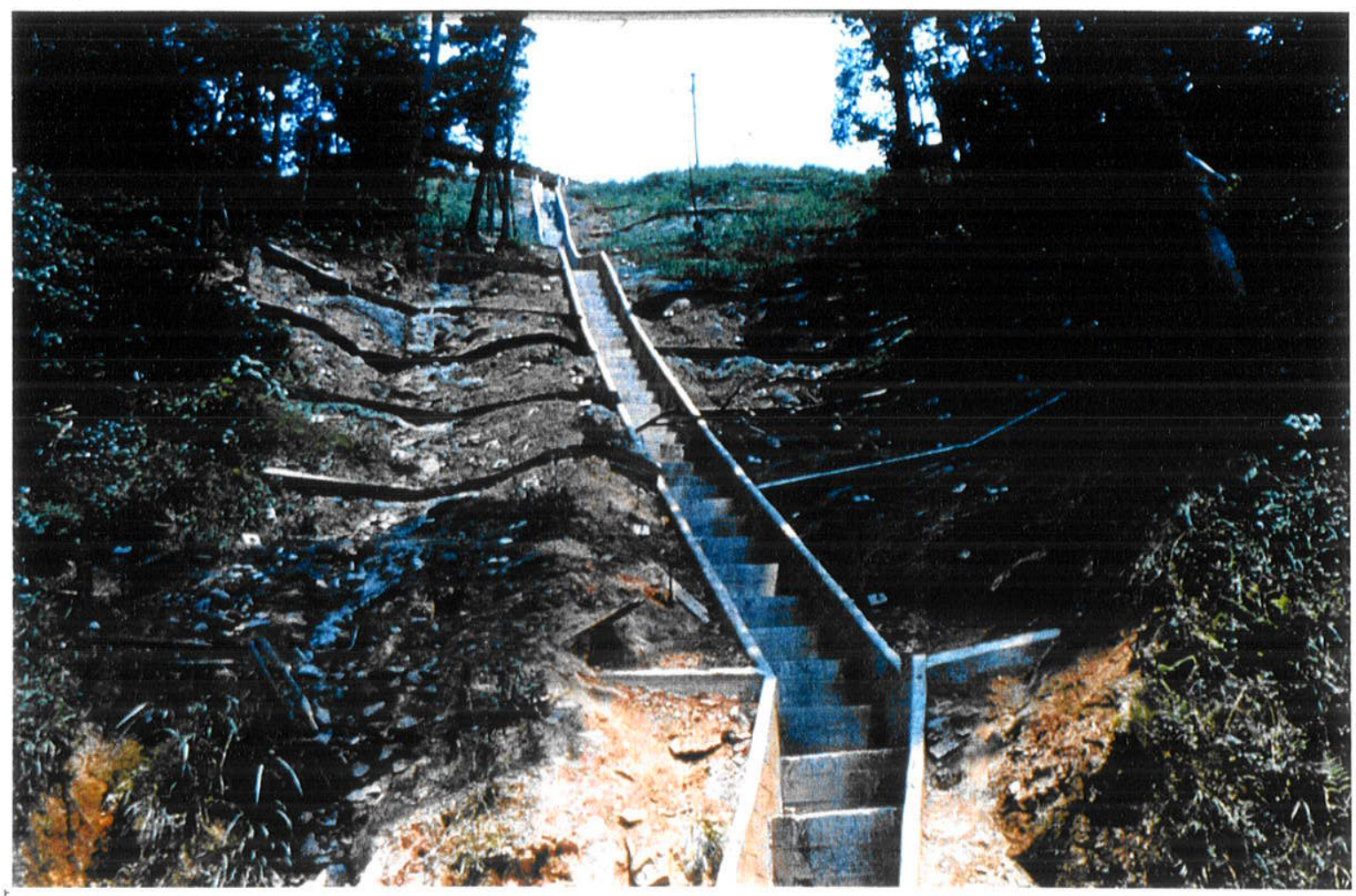

Fotografia VII.4.1.5. Drenagem superficial - escada hidráulica

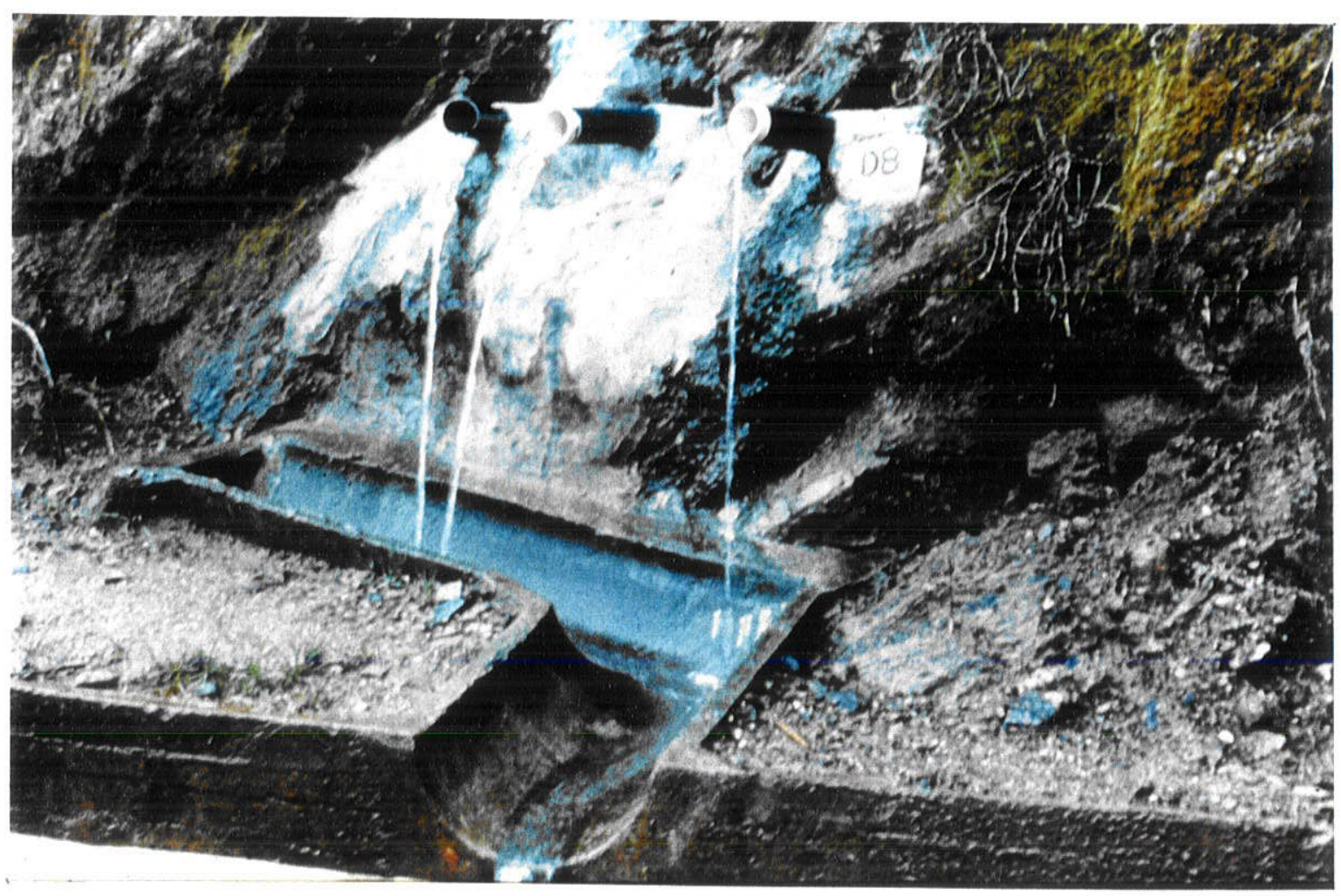

Fotografia VII.4.1.6. Drenos tubulares profundos em região de tálus 


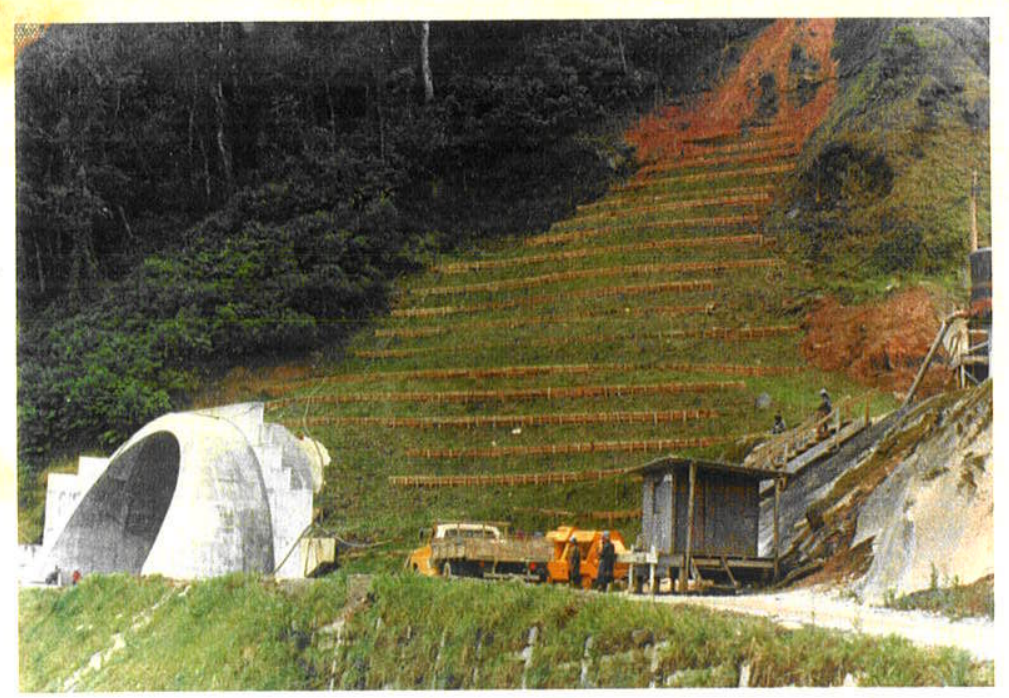

Fotografia VII.4.1.7. Cordões vegetais em encosta sobre emboque de túnel

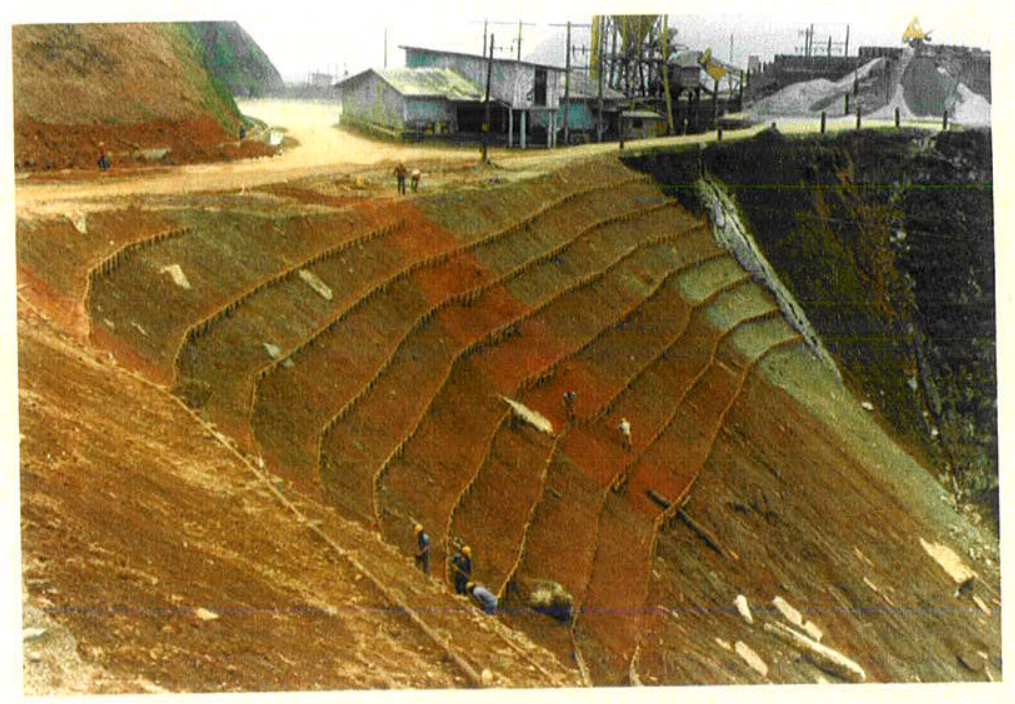

Fotografia VII.4.1.8. Cordões vegetais em encosta de estrada de serviço 
VII.4.2. Muros atirantados.

Esses muros foram executados sistemáticamente durante a construção da Rodovia dos Imigrantes, existindo tambem em alguns pontos das outras rodovias e na ferrovia.

$\mathrm{Na}$ Imigrantes, eles são de 3 tipos, conforme ilustrado na Figura VII.4.2.1.

O tipo contínuo, já foi mostrado anteriormente na Fotografia VII.4.1.1.

Os muros de placas retangulares e sapatas isoladas, aparecem em seguida, nas

Fotografias VII.4.2.1. e VII.4.2.2.

Alem dos muros, foram tambem executados tirantes com sapatas protendidas isoladas e acompanhando a morfologia do terreno, como exemplificado na Fotografia VII.4.2.3.

Os muros $e$ as sapatas isoladas, tem sido chamados indistintamente de cortinas atirantadas ou cortinas protendidas. Seu funcionamento está baseado na contenção da massa de terreno instável e sujeita a escorregamento (que vai da superfície do talude até a provável superfície de ruptura), pela protensão introduzida pelos tirantes, conforme exposto resumidamente a seguir.

O tirante como sabemos é constituido basicamente de 3 partes:

1a. Cabeça de cravação. É sua parte externa, geralmente revestida por concreto e visível junto à parede da cortina. Funciona como "a cabeça de um parafuso".

2a. Trecho livre. É o trecho que vai ser tensionado e que quando o tirante está instalado, vai da face do talude, até ultrapassar um pouco a linha da provável superfície de ruptura, no interior do maciço.

3a. Trecho de ancoragem. É o trecho na extremidade interna do tirante, que fica ancorado ao maciço estável, através de calda de cimento (nos casos exemplificados).

O tirante é montado fora e introduzido no maciço, através de um furo, executado em diâmetro adequado, atravessando cortina +talude e penetrando até a profundidade prevista, conforme as especificaçóes de projeto.

Uma vez ancorado, vem a fase de protensão do tirante, que é realizada através de um macaco hidráulico acoplado à sua extremidade externa (onde ficará a cabeça de cravação), junto à face da cortina. Durante esta fase o tirante é tensionado no seu trecho livre, fazendo com que essa tensão seja transmitida ao trecho de ancoragem, resultando assim numa zona de terreno comprimida entre a parede da cortina e o ponto de ancoragem (Fotografias VII.4.2.4. a VII.4.2.7.).

Os tirantes mais utilizados na Rodovia dos Imigrantes, foram os de 12 fios de aço, com diâmetros de $7 \mathrm{~mm}$ e $8 \mathrm{~mm}$, para cargas de trabalho respectivamente de 29 e 38 toneladas, com coeficiente de segurança de 2,0 (MACHADO FILHO, 1976).

Seus comprimentos variaram bastante, em função da necessidade de cada local, geralmente entre 12 e $25 \mathrm{~m}$, totalizando nessa rodovia, algumas dezenas de milhares de metros executados. 


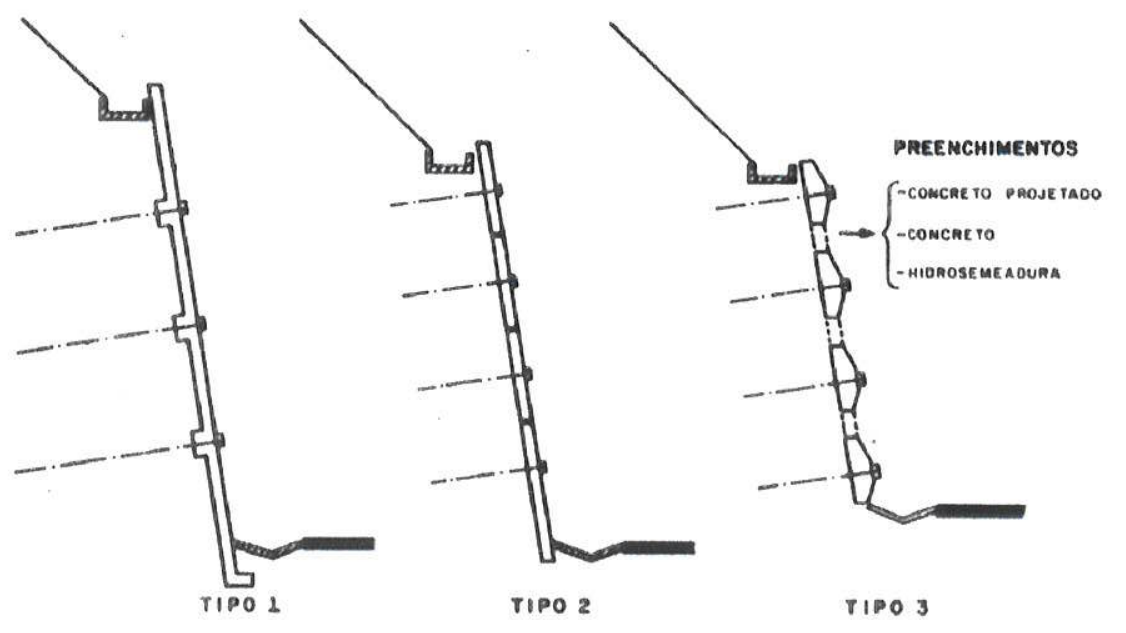

TIPO 1: Muro atirantado contínuo

TIPO 2: Muro de placas retangulares

TIPO 3: Muro de sapatas isoladas

Figura VII.4.2.1. Tipos de muros atirantados na Rodovia dos Imigrantes

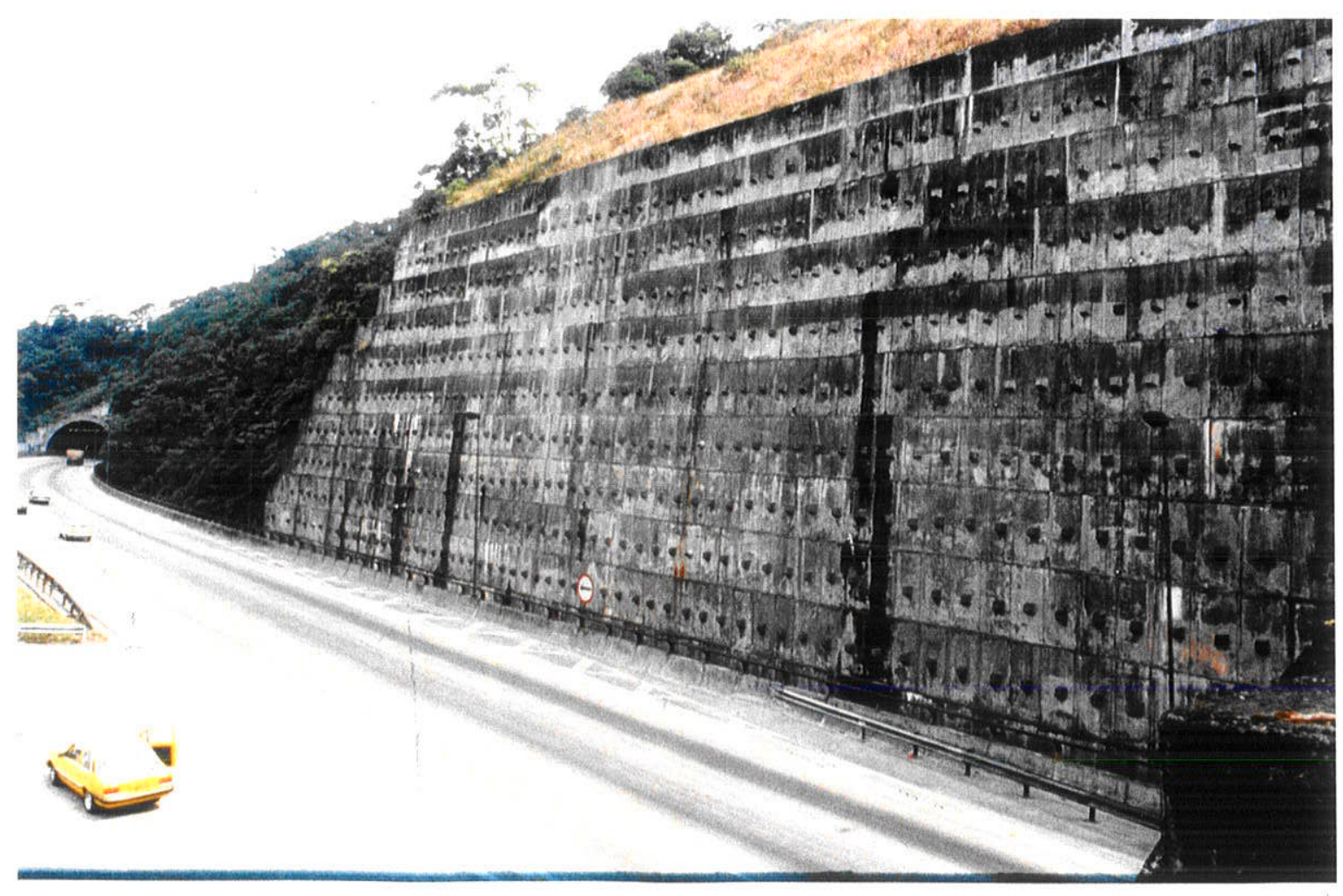

Fotografia VII.4.2.1. Muro atirantado de placas retangulares na Rodovia dos Imigrantes 


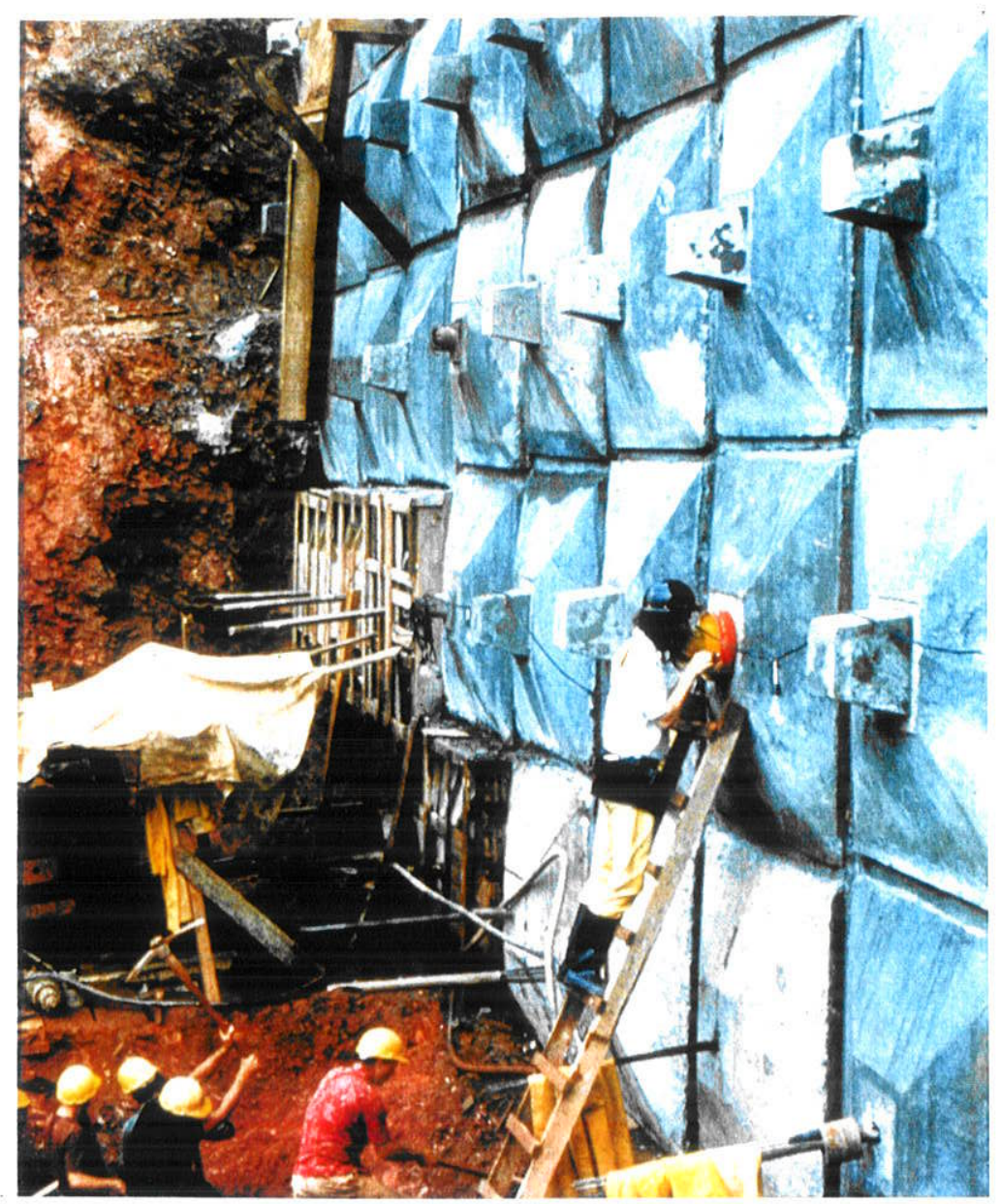

Fotografia VII.4.2.2. Muro de sapatas atirantadas

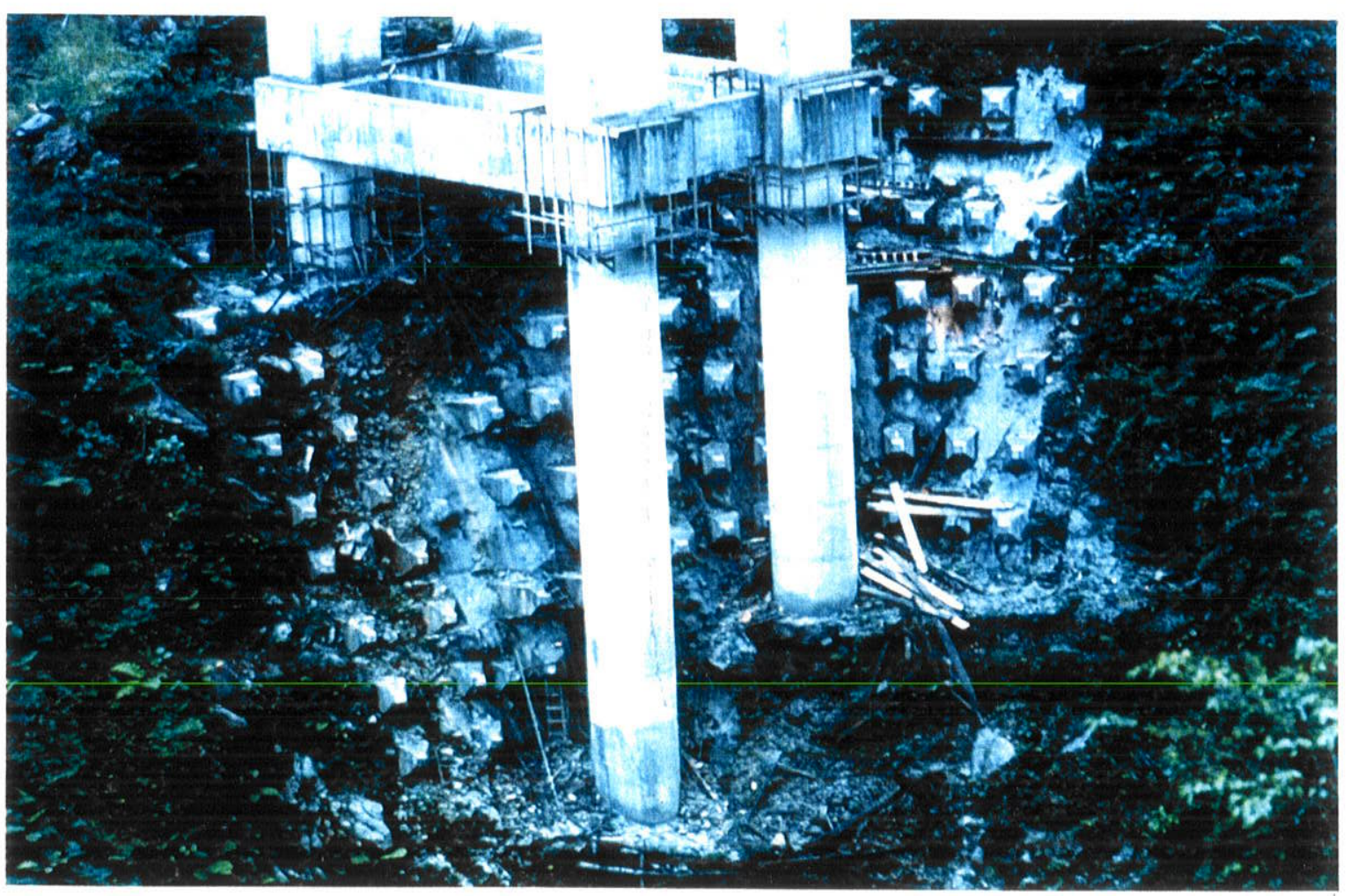

Fotografia VII.4.2.3. Sapatas atirantadas reforçando zona de fundação de viaduto, na Rodovia dos Imigrantes 


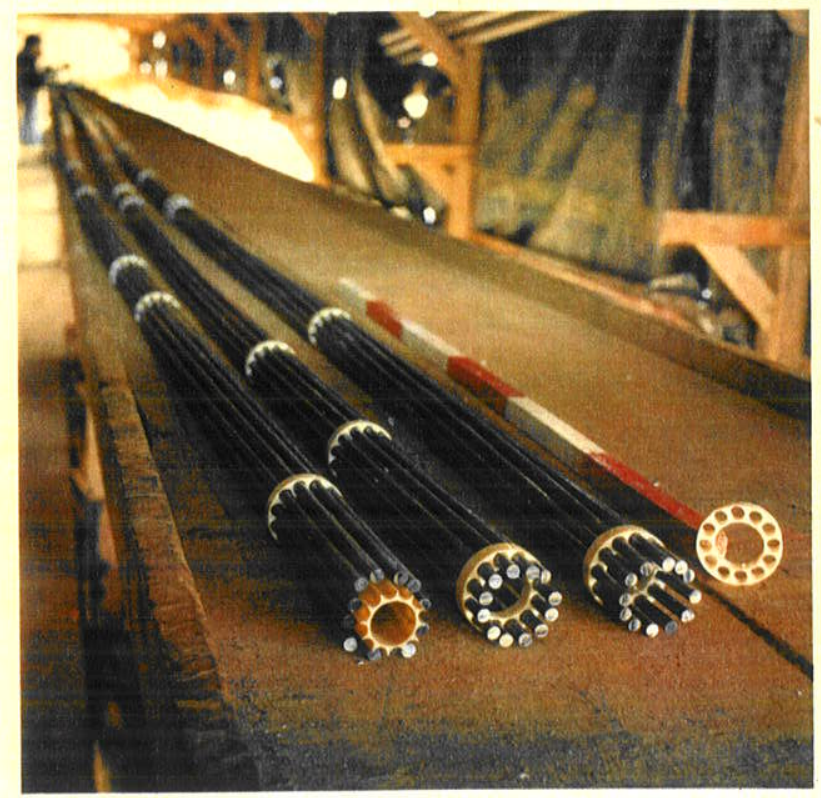

Fotografia VII.4.2.4. Tirante de 12 fios de aço, em fase de montagem

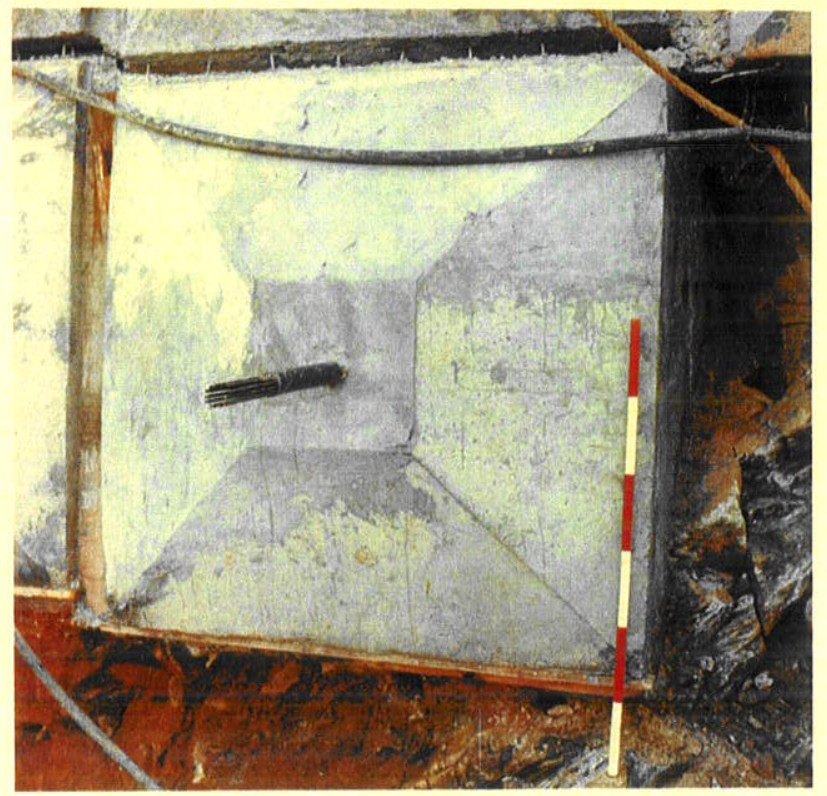

Fotografia VII.4.2.5. Sapata de concreto, com tirante posicionado
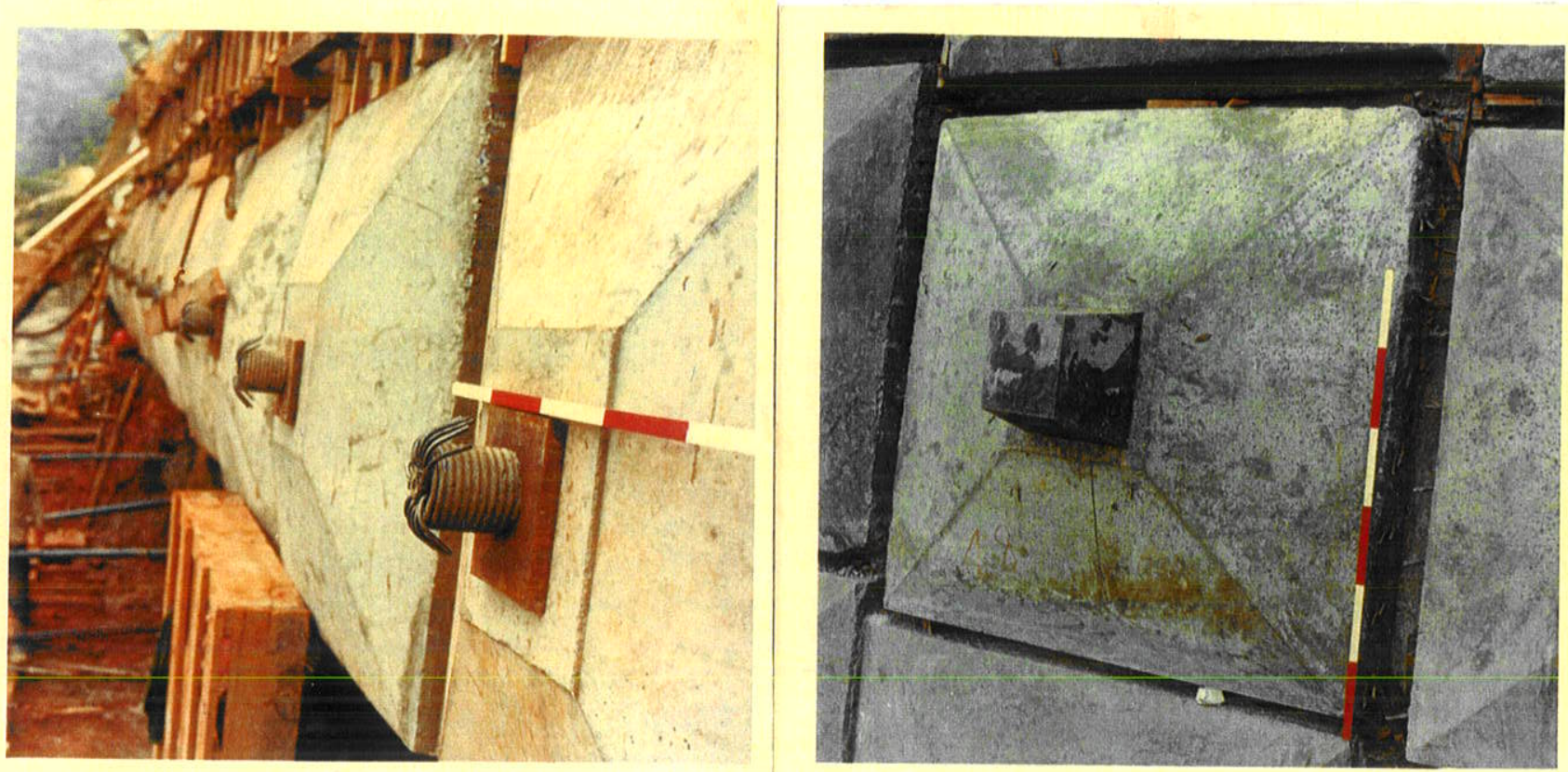

Fotografia VII.4.2.6. Tirante já protendido, Fotografia VII.4.2.7. Sapata terminada, com com a cabeça de cravação a cabeça do tirante revestida 
Esse tipo de tratamento, conhecido na Itália como "pali radice", foi trazido ao Brasil por um consórcio ítalo-brasileiro, para contenção de encostas da Rodovia dos Imigrantes, em locais considerados críticos, onde não se desejava introduzir novas tensões no maciço, como ocorre com as cortinas atirantadas.

As estacas-raiz são executadas para formar uma estrutura reticulada, atravessando toda a zona instável do terreno, até ultrapassar a linha da provável superfície de ruptura. Constituem portanto, uma armadura, solidarizando todas as partes do maciço, o qual passa a ter o comportamento de um monolito, com todas as tensões internas igualmente distribuidas (Figura VII.4.3.1. e Fotografias VII.4.3.1. e VII.4.3.2.).

São estacas de pequeno diâmetro (foram usadas de $10 \mathrm{~mm}$ ), armadas com um vergalhão de aço e moldadas no local, executadas de $3 \mathrm{em} 3$, com diferentes inclinações partindo de um mesmo ponto, onde são providas de uma cabeça comum. Essas cabeças são unidas em linhas, formando vigas de concreto armado na superfície, acompanhando a morfologia da encosta. Entre as vigas é presa uma tela de aço galvanizado, para impedir a queda de blocos.

Essa metodologia foi usada para reforçar algumas regióes rochosas alteradas $e$ fraturadas junto ao emboques de túneis, bem como em áreas muito problemáticas, nas vizinhanças de tubulões de viadutos.

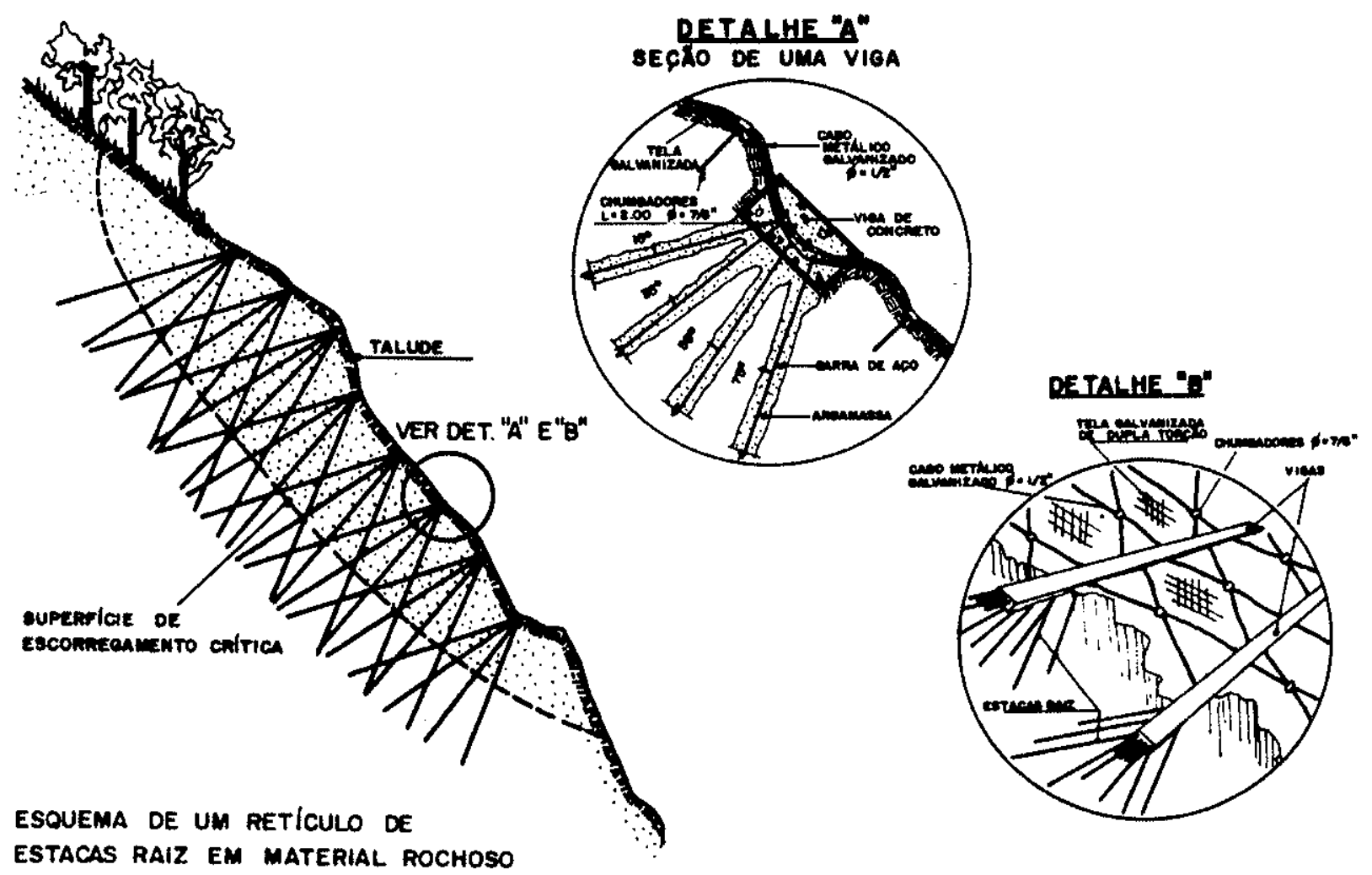

Figura VII.4.3.1. Contenção de encosta com estacas-raiz.

(Hessing, 1976) 


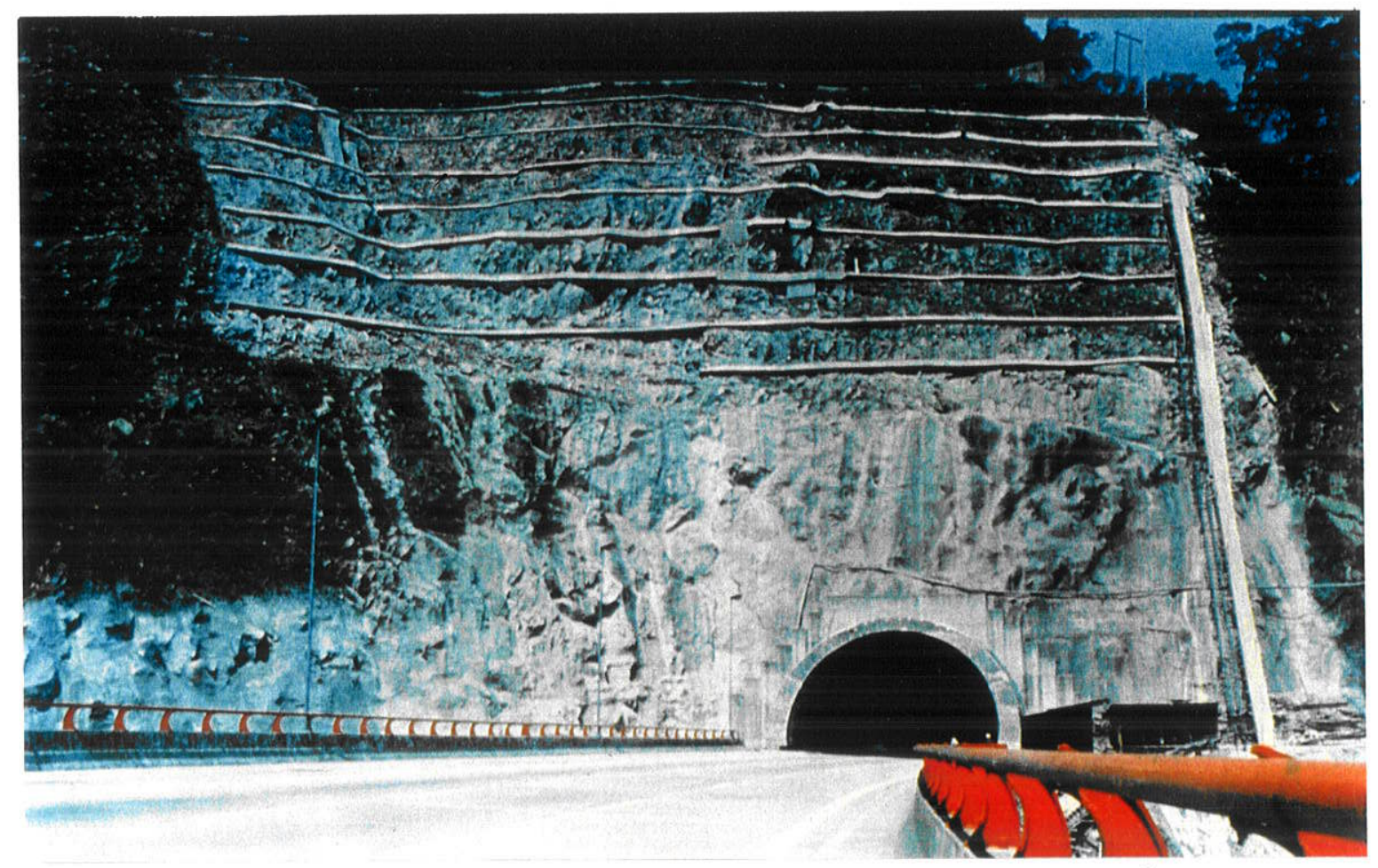

Fotografia VII.4.3.1. Estacas-raiz em encosta a montante de emboque de túnel, na Rodovia dos Imigrantes

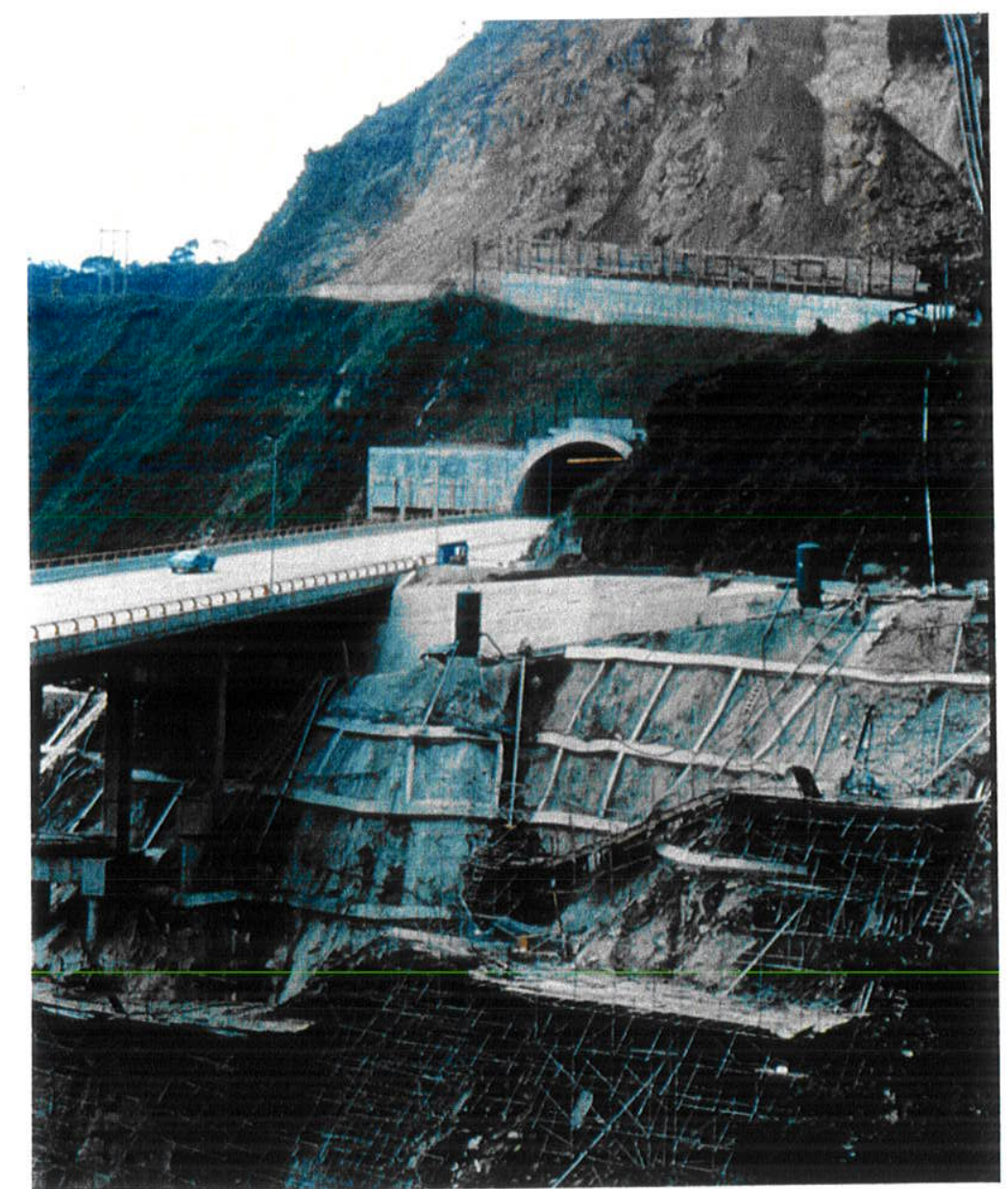

Fotografia VII.4.3.2. Estacas-raiz reforçando encosta em zona de fundação de viaduto, na Rodovia dos Imigrantes 


\section{VII.4.4. Gabião e "crib-wall".}

Gabião é um termo usual, proveniente de "gavione" em italiano e que designa células com diversas formas e dimensões (caixa, cilindro, colchão, etc.), construidas com tela de arame galvanizado trançado, de diâmetro 2,5 a 3,0 $\mathrm{mm}$. Essas células, são preenchidas por material rochoso, formando estruturas de arrimo permeáveis e flexíveis que podem acompanhar e absorver deformações do terreno. São situações onde estruturas rígidas, como muros de concreto, não poderiam ser utilizadas. Gabião tipo caixa, tambem conhecido por gaiola, está exemplificado nas Figura VII.4.4.1. A Fotografia VII.4.4.1., ilustra a utilização de gabiões tipo caixa (nos muros laterais) e tipo colchão (no leito), em canal de drenagem.

Apesar de ser uma estrutura flexível, o gabião não prescinde de uma fundação adequada, na qual não ocorra recalque excessivo, pois do contrário terá sua função bastante prejudicada.

Outra modalidade de contenção, mais pesada e muito eficiente é o "crib-wall", que foi usado usado como muro de arrimo e fundação, em vários trechos das estradas de serviço da Rodovia dos Imigrantes, suportando tráfego intenso de caminhões fora-de-estrada. O termo "crib-wall", não tem um correspondente adequado em português, designando muros ou paredes formadas por células articuladas, montadas com peças pré-fabricadas de concreto armado, com a forma de barras ou hastes. Essas células, são preenchidas por material granular rochoso (Fotografia VII.4.4.2.).

O "crib-wall", foi usado em fileiras simples ou dupla, nas situações mencionadas, estando ainda hoje em boas condições. Sendo uma estrutura pesada, exige melhor fundação que o gabião. Por ser articulado, permite a absorção de pequenas deformações do terreno, não tendo porem a flexibilidade do gabião.

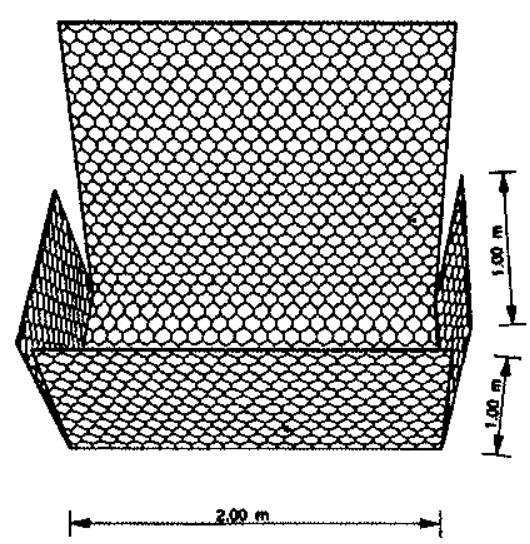

A: armação de gaiola simples

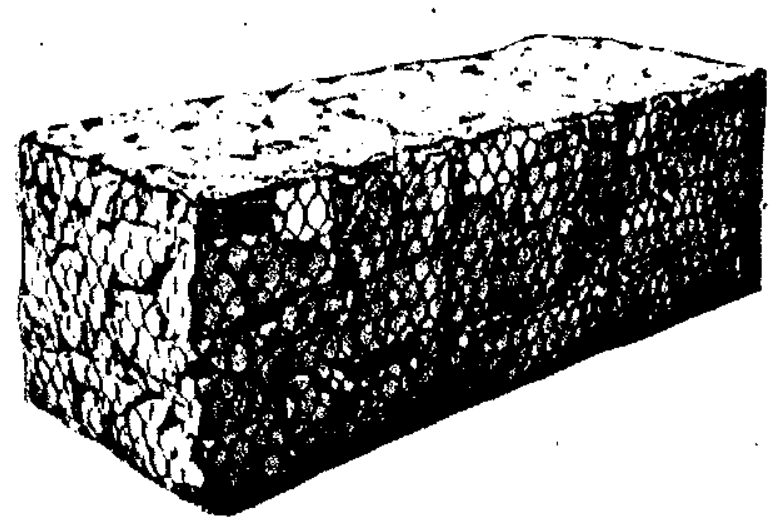

B: gaiola tripla preenchida

Figura VII.4.4.1. Gabião tipo caixa ou gaiola.

(Maccaferri, 1979) 


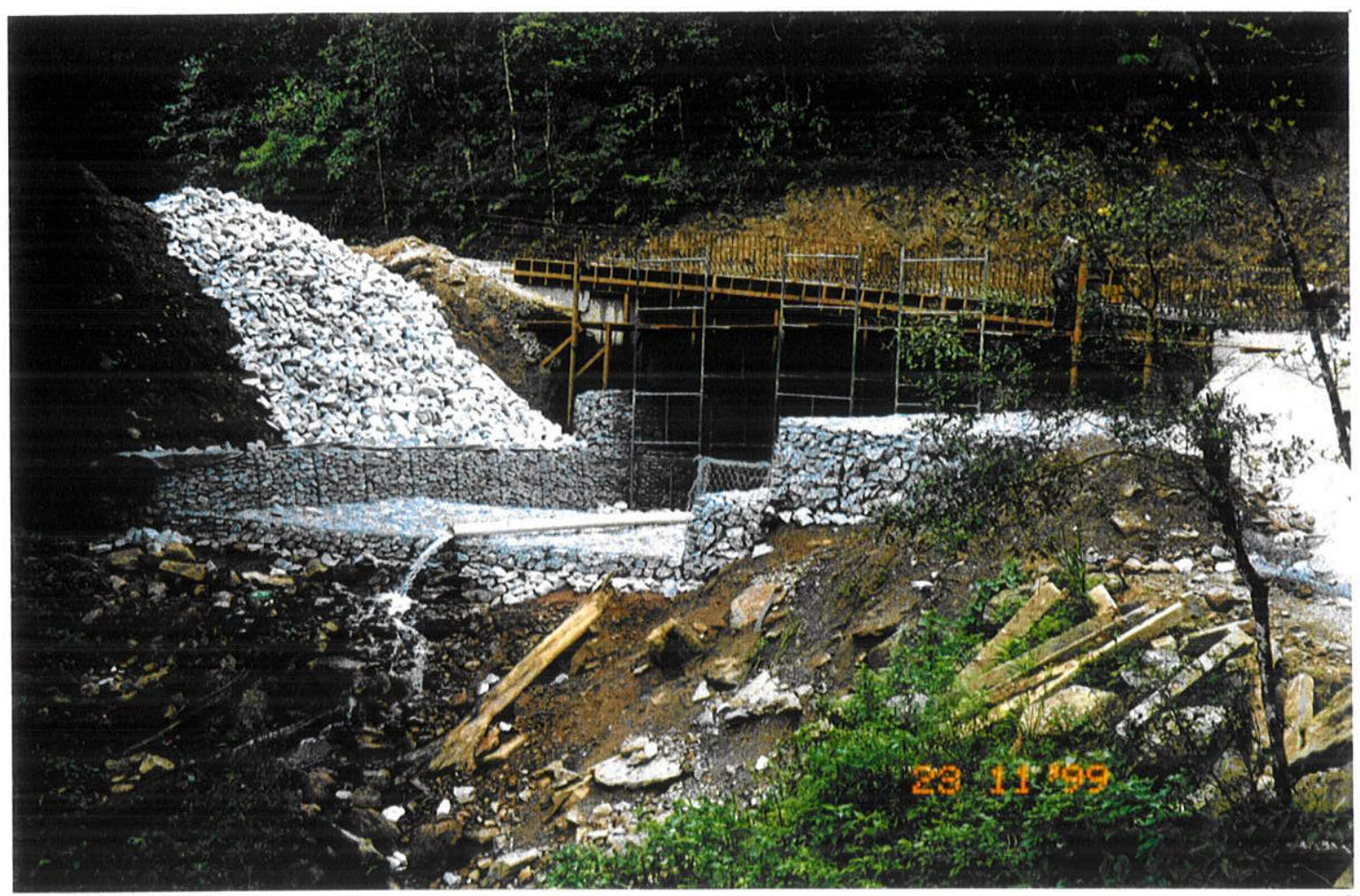

Fotografia VII.4.4.1. Canal de drenagem construido com muros e colchão de gabiões, na estrada de serviço.

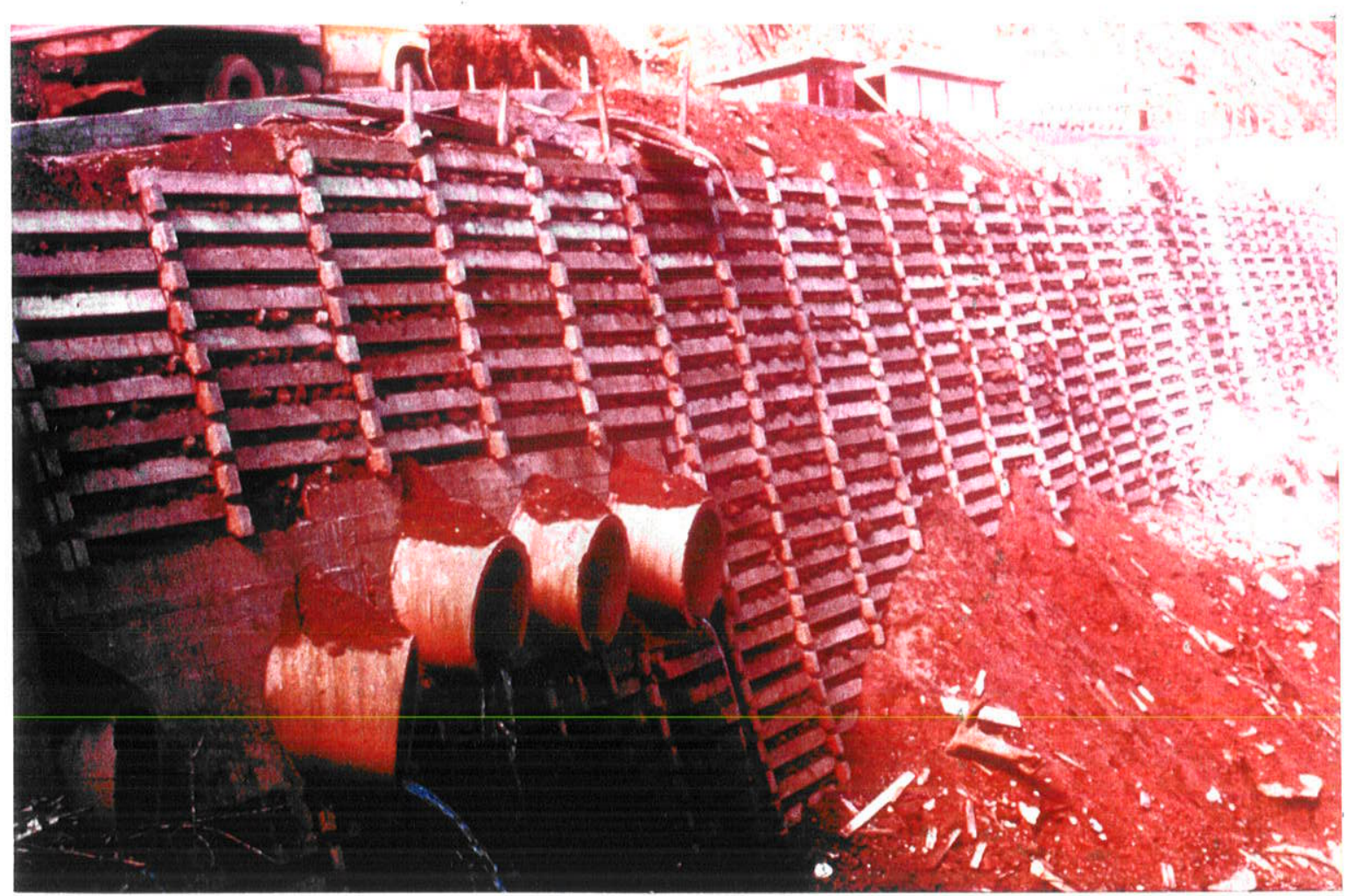

Fotografia VII.4.4.2. Estrada de serviço no trecho da serra, construida sobre "crib-wall" 
VII.4.5. Anéis de proteção em viadutos.

Foi uma solução adotada nas zonas de tálus atravessadas pelos viadutos VA-19 e VA-20 da Rodovia dos Imigrantes.

O VA-19, com $1920 \mathrm{~m}$ de comprimento, tem cerca de $40 \%$ de seu desenvolvimento numa zona de tálus com espessura variando de 6 a $12 \mathrm{~m}$. O VA-20, com $1070 \mathrm{~m}$, tem $25 \%$ de seu desenvolvimento em outra zona de tálus, bem mais espesso, geralmente com mais de $10 \mathrm{~m}$, alcançando $22 \mathrm{~m}$ junto à margem do rio Cubatão.

Embora conhecidos por anéis de proteção, essas estruturas constituem na verdade, camisas cilíndricas de concreto armado, envolvendo os tubulóes dos viadutos, na sua seção escavada em tálus. Entre a parede interna do anel e a parede externa do tubulão, permanece um espaço anelar vazio (Figura VII.4.5.1. e Fotografia VII.4.5.1.). Na fotografia, existem tambem muros de gabião, com a função de impedir que material superficial possa deslizar e cair dentro do espaço vazio do anel.

Partindo da premissa de que o tálus é uma formação geológica potencialmente instável e sujeita a movimentação, o anel foi concebido para se deslocar junto com o tálus, sem entretanto deixar que essa massa encoste no tubulão. Assim sendo, o mesmo fica preservado de qualquer empuxo, que de outra forma teria efeito cisalhante na estrutura do viaduto.

Não sendo bem conhecidas as condições e velocidades dessa movimentação, admitiu-se que o anel, tal como foi construido, poderia funcionar perfeitamente por cerca de 15 anos, após os quais, a sua aproximação dos tubulões exigiria a construção de novo anel circundante.

O movimento de deslocamento dos anéis, em relação aos tubulões, tem sido monitorado desde 1974 e, até março de 2000 , não havia surgido a necessidade de novas construções desse tipo, mostrando que o movimento desses tálus é bastante lento, sabendo-se que se encontra praticamente estabilizado em vários pontos. 


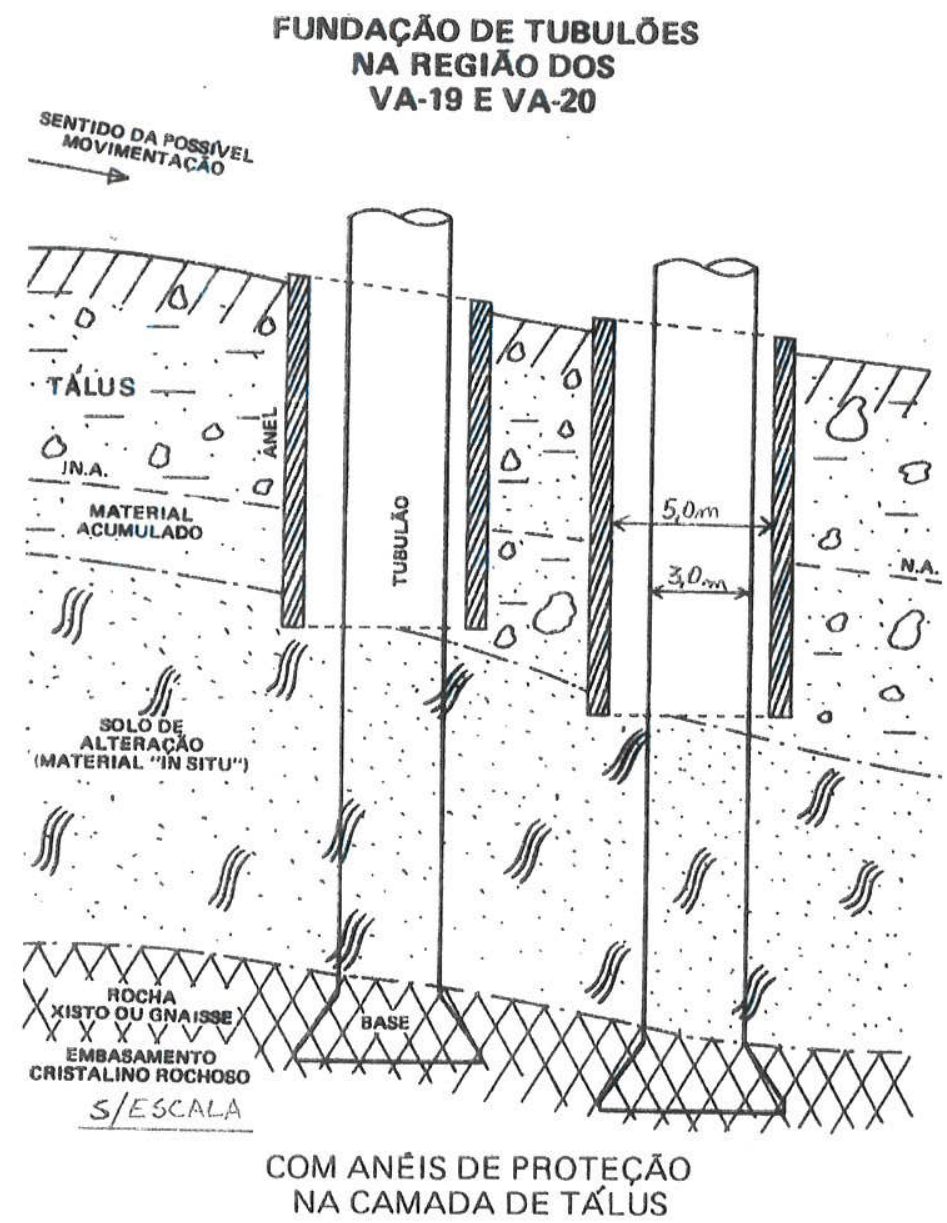

Figura VII.4.5.1. Seção geológica esquemática em região de tálus, com anéis de proteção. (Machado Filho, 1974)

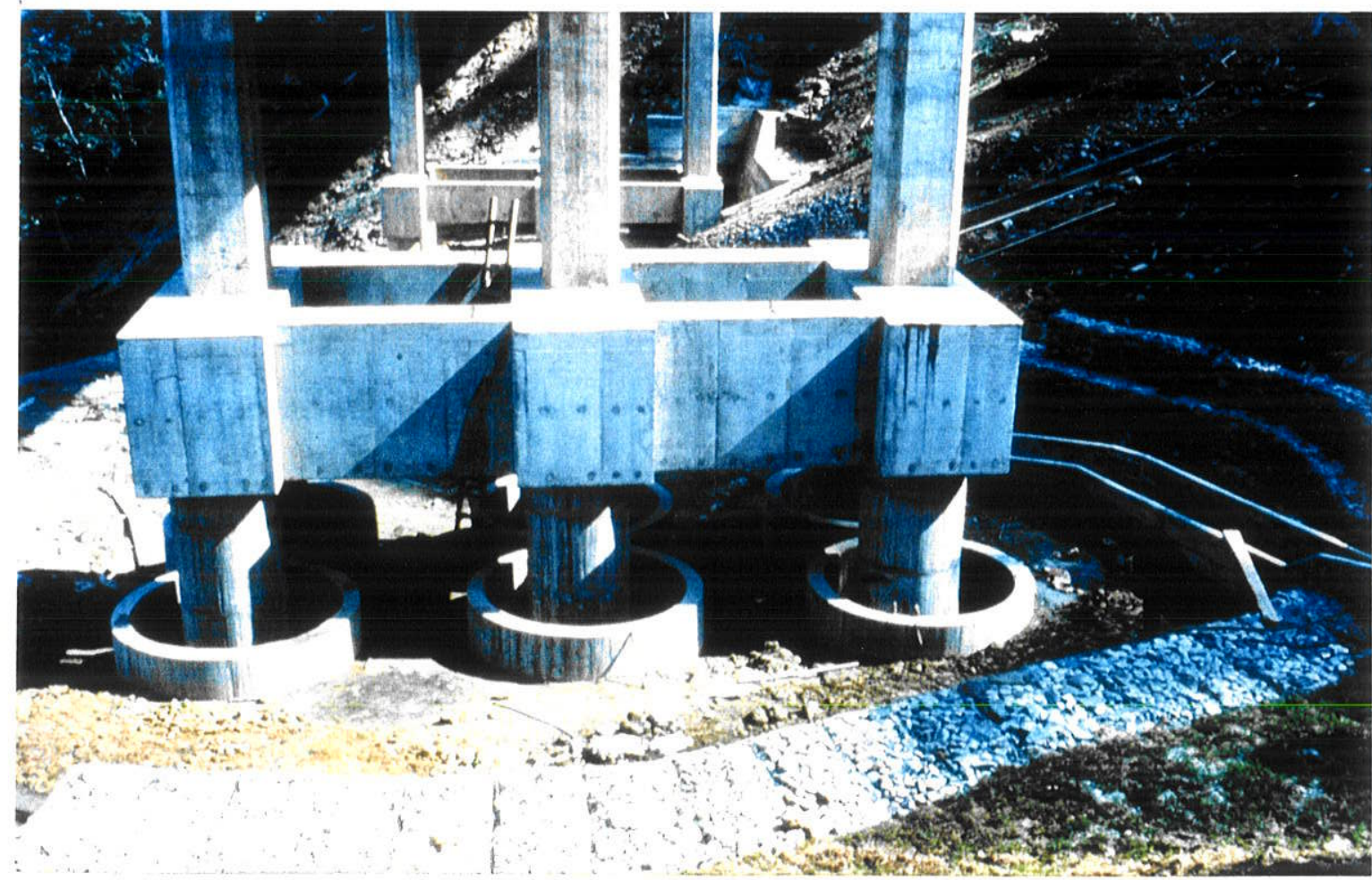

Fotografia VII.4.5.1. Anéis de proteção em viaduto da Rodovia dos Imigrantes 


\title{
CAPítULO VIII
}

\section{EXEMPLOS HISTÓRICOS DE INSTABILIZAÇõES NA ÁREA.}

\author{
VIII.1. OS BAIRROS-COTA DA VIA ANCHIETA
}

Os "Bairros-Cota" da Via Anchieta, constituem um dos casos brasileiros mais notáveis de ocupação humana em encostas instáveis (MACHADO FILHO, 1984). A história da ocupação remonta ao ano de 1938, com o início da construção da Via Anchieta, rodovia que corta o Parque Estadual da Serra do Mar, época em que foram estabelecidos os primeiros acampamentos de obras, os quais se transformaram posteriormente em moradias para as famílias dos trabalhadores que permaneceram fazendo a manutenção da rodovia.

Com a abertura ao tráfego da primeira pista da Via Anchieta em 1947, populações de baixa renda, aproveitando-se desses aglomerados iniciais, passaram a invadir as áreas vizinhas. O processo ganhou vulto com a implantação do Polo Petro-Químico de Cubatão, cujo município não contava com um planejamento consistente para fazer face à expansão urbana e habitacional.

Em 1969, quando da criação da DERSA, empresa que recebeu a concessão para administrar a Via Anchieta, já existiam no trecho da Serra de Cubatão, inúmeros núcleos habitacionais, instalados na faixa lindeira da rodovia e ocupados por operários e suas familias.

Com a expansão industrial de Cubatão e sua deficiência de infraestrutura habitacional, passou a ocorrer uma ocupação humana crescente e desordenada de áreas impróprias, tanto no manguesal da Baixada Santista como nas encostas da Serra de Cubatão.

As encostas da serra, com água abundante e ar puro, eram particularmente atraentes para essas populaçóes de pouco poder aquisitivo, que para lá foram migrando e constituindo novos núcleos, enquanto os antigos iam se adensando, formando-se assim os Bairros-Cota nos seguintes locais:

- Cota 500 - km 44,5

- Cota 400 - km 47,5 (quilometragem referida

- Cota 200 - km 49,0 à pista descendente).

- Cota 95-km 52,0

A localização dos "Bairros-Cota", está indicada na Figura VIII.1.1. 


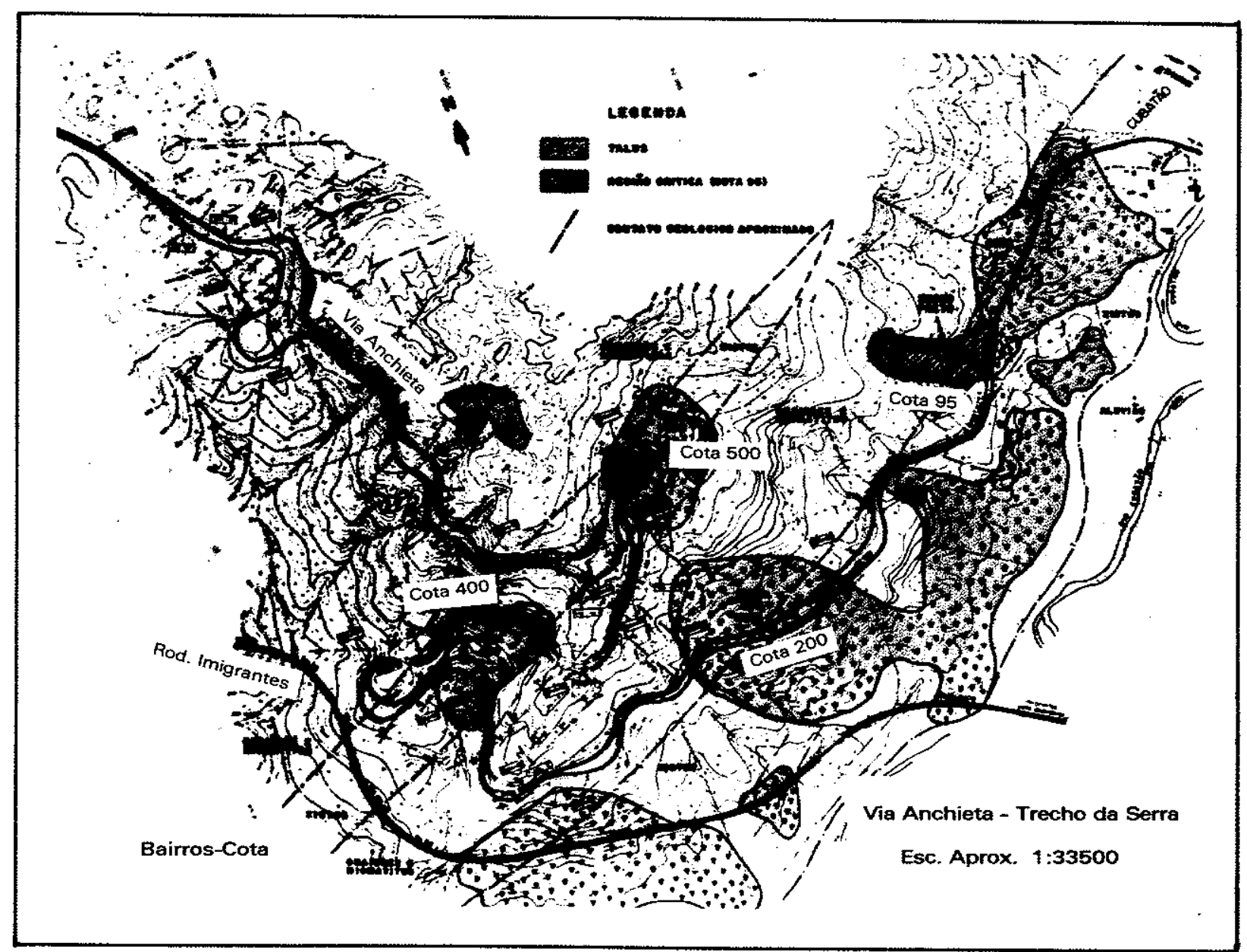

Figura VIII.1.1. Localização dos Bairros-Cota. 
Esses bairros ocupam, na sua maior parte, áreas recobertas por formações de tálus, as quais por possuirem topografia mais favorável que as encostas serranas vizinhas, facilitam a implantação das moradias, malgrado os riscos geotécnicos envolvidos.

Levantamentos do Instituto Florestal em 1978, acusava 3200 moradores nesses locais. Entretanto, a expansão tomou vulto na década de 80 , quando houve implantação de serviços de infraestrutura de apoio às populações, como fornecimento regular de luz elétrica, linhas de ônibus, Postos de saúde, escolas, etc., consolidando definitivamente a ocupação humana. Em 1990, estimativas de técnicos da DERSA, acusavam mais de 20000 pessoas residentes nessas áreas (Fotografias VIII.1.1 e VIII.1.2).

Não dispomos de uma estimativa atualizada da população local, mas certamente houve aumento nesta última década. Números não oficiais noticiados pela imprensa e atribuidos à entidades de defesa ambiental, referem-se a 30000 pessoas.

Os Bairros-Cota tem sido objeto de diversos estudos técnicos por parte de órgãos governamentais e particulares (DERSA, SEMA, IPT, Prefeitura de Cubatão, Instituto Florestal, etc.), com a preparação de cartas de risco geotécnico, elaboração de programas simples de monitoramento da movimentação dos tálus, conscientização das populações - inclusive nas escolas, planos para evacuação de emergência nas épocas de chuvas, etc.

Esse trabalho, ainda que longe do ideal, tem evitado até o momento, a ocorrência de tragédias de grande porte, só se conhecendo casos isolados. 


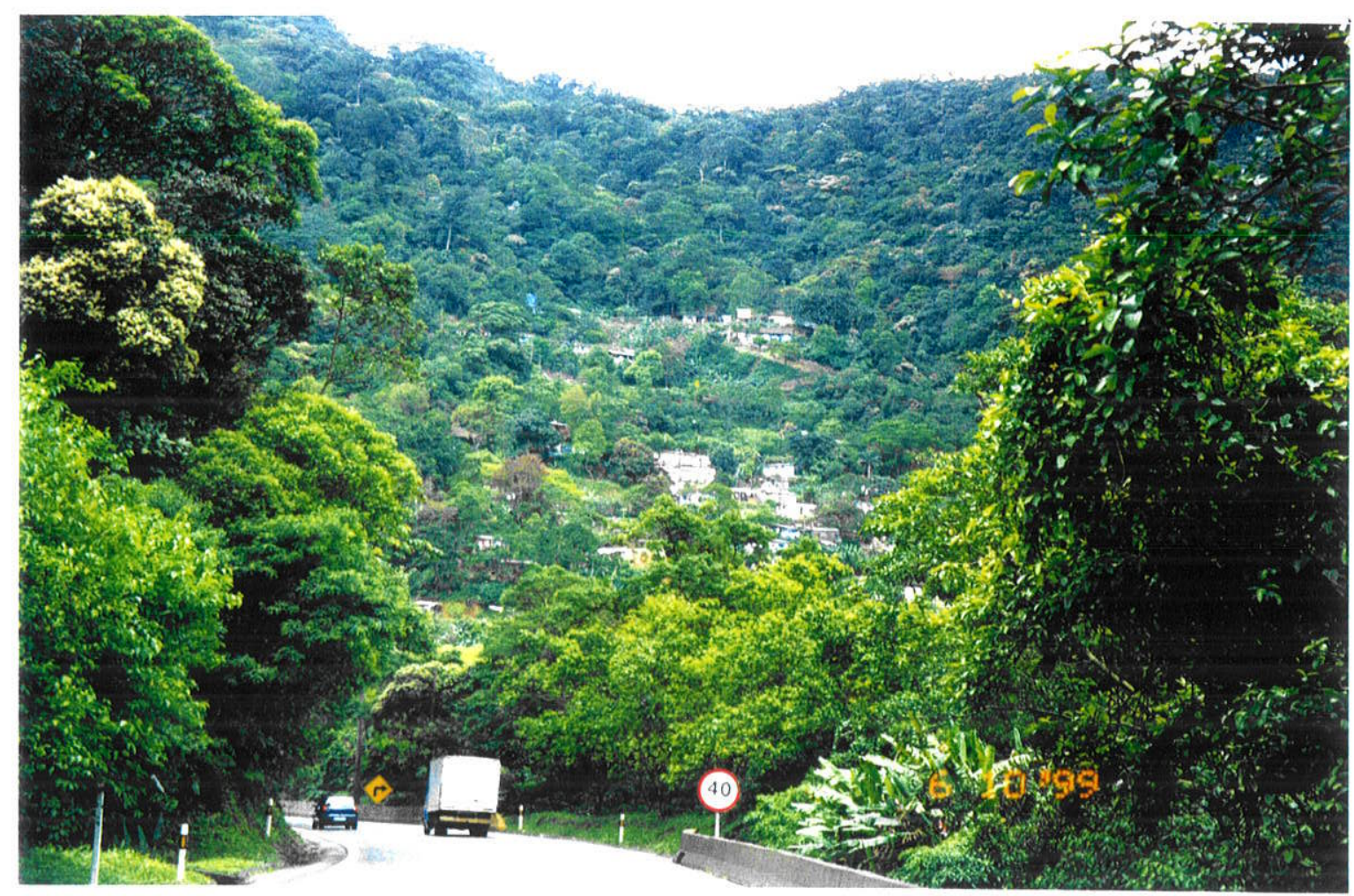

Fotografia VIII.1.1. Vista parcial do bairro na Cota 400

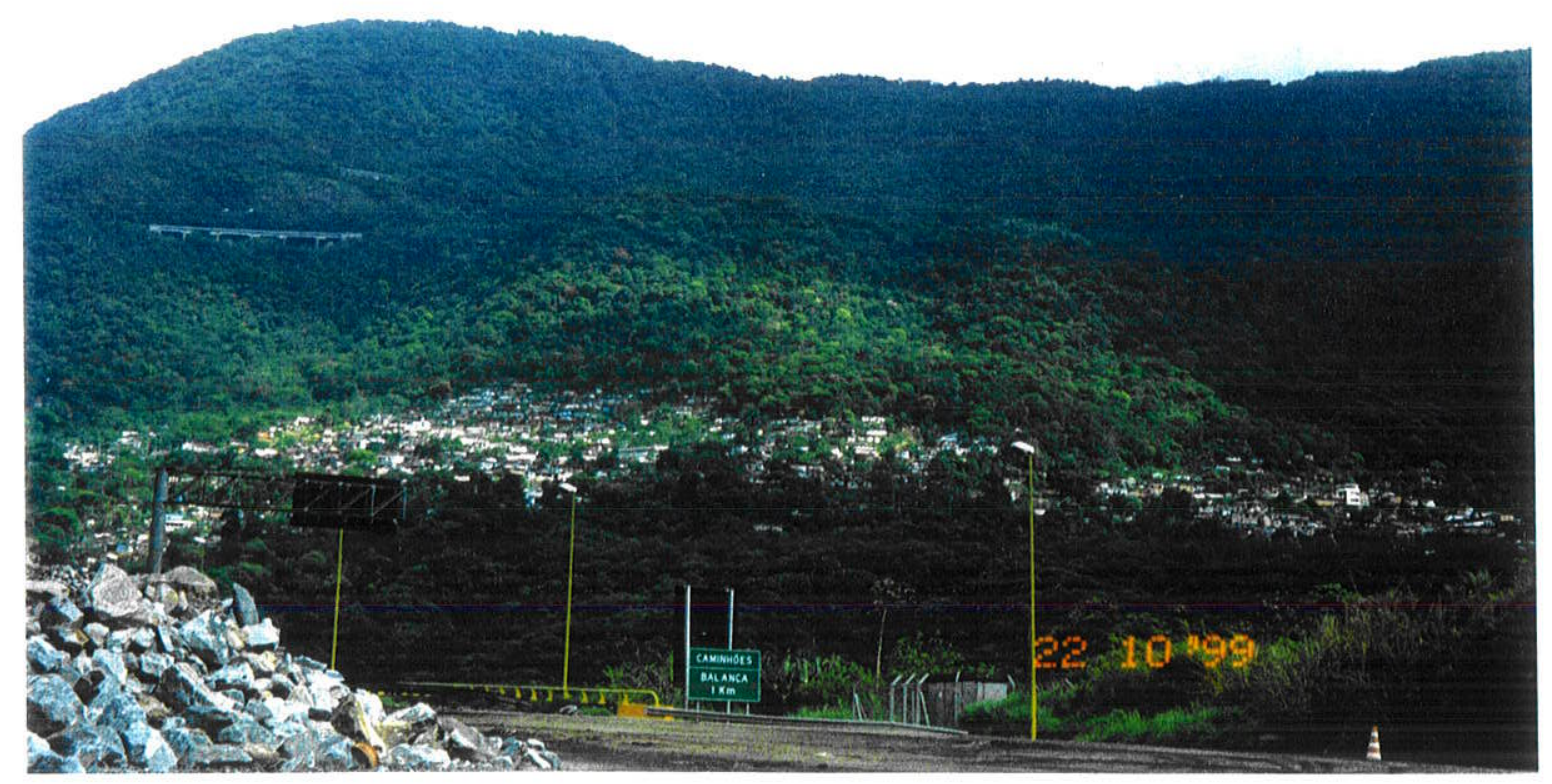

Fotografia VIII.1.2. Bairros-Cota nas encostas da Serra de Cubatão 
O Morro Preto, na cota 95, merece um destaque especial:

É conhecido por esse nome, devido sua aparência escura resultante do revestimento betuminoso aí executado.

Trata-se de uma encosta de tálus, historicamente conhecida por escorregamentos geológicos recorrentes atingindo a pista da rodovia. A instabilizaçào do local teve início logo após a execução do corte para construção da Via Anchieta, provocando deslocamentos horizontais no sentido do vale e deslocamentos verticais com alteamento da pista de alguns metros, causados pelo movimento da massa segundo cunha circular de escorregamento. O movimento sofria recorrência, cada vez que se retirava material tentando restaurar o greide da rodovia, uma vez que era removido o empuxo passivo, causando novo desequilíbrio.

A encosta sofreu vultoso tratamento geotécnico de estabilização na década de 50 , incluindo: retaludamento com bermas de equilíbrio, impermeabilizaçao superficial betuminosa, execução de galerias e drenos profundos, construção de canaletas superficiais, escadas hidráulicas, etc. (RODRIGUES, 1951).

Até 1982, havia poucas casas na região vizinha ao local. Nesse ano entretanto, antecedendo período eleitoral, a área foi subitamente invadida por grande número de pessoas, sendo que, em poucos meses, já contava com cerca de 50 moradias (MACHADO FILHO, 1984), conforme ilustrado nas Fotografias VIII.1.3 e VIII.1.4.

A implantação dessas moradias causou diversos estragos à area tratada:

- destruição parcial do revestimento betuminoso superficial, para a construção das moradias, cercas, pequenas hortas, etc;

- desvio das águas dos drenos tubulares profundos, que ao invés de serem captadas pelas canaletas de drenagem eram desviadas para consumo e posteriormente reinjetadas no subsolo, na forma de esgotos;

- obstrução e danos às canaletas superficiais;

- danos aos piezômetros e marcos topográficos:

- cortes e degraus nos taludes para a execução de escadas entre as "ruas", localizadas nas bermas de equilibrio.

A situação foi denunciada por geólogos e ambientalistas e veiculada pela imprensa da época, em rádios, jornais e televisão, alertando as autoridades face aos grandes riscos envolvidos. Após preparação de áreas aterradas na Baixada Santista (Prefeitura de Cubatão e Governo Estadual), o poder público promoveu a remoção da população do Morro Preto, tendo então sido restaurado o tratamento geotécnico e o monitoramento geomecânico dessa encosta. 

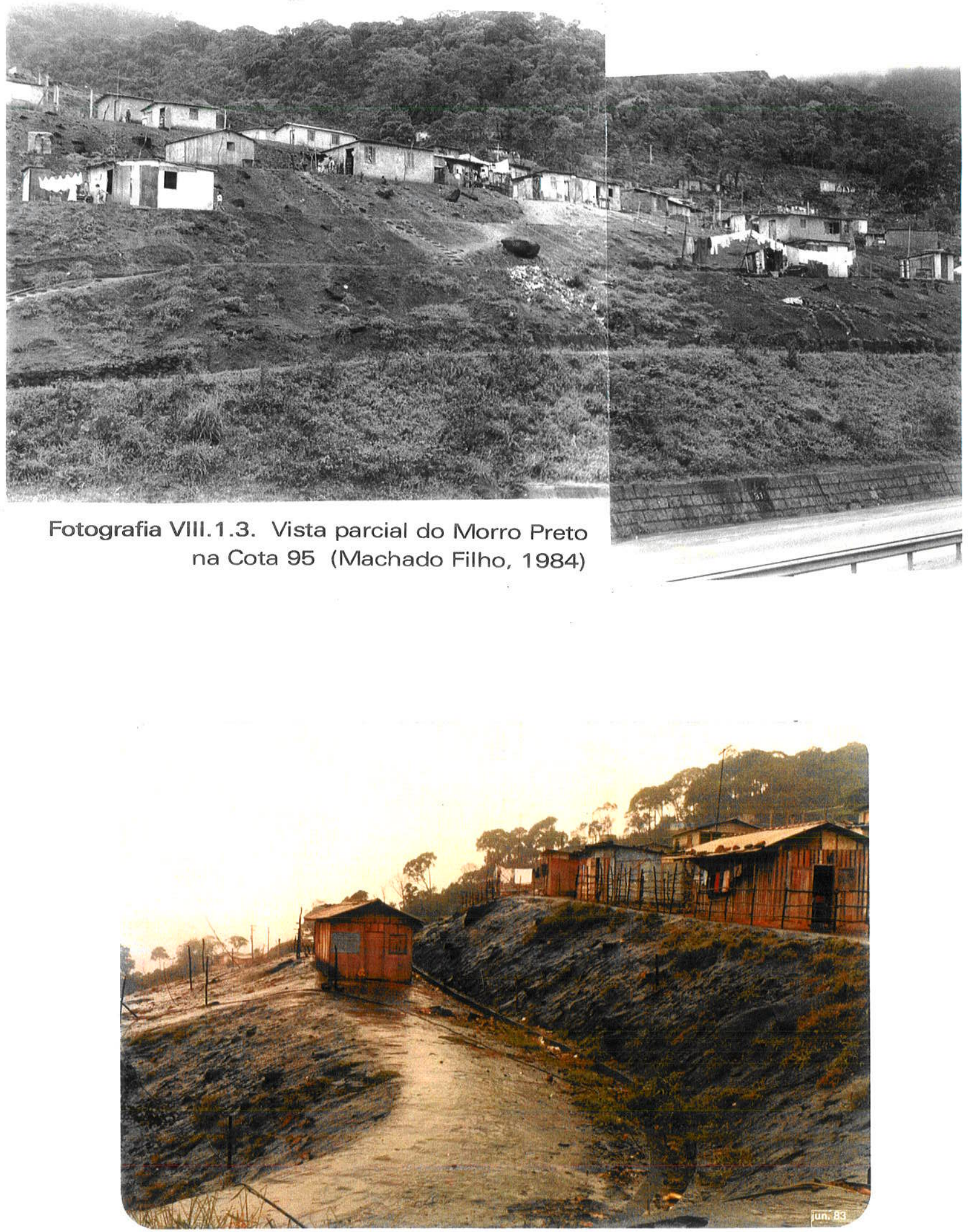

Fotografia VIII.1.4. Casa sobre. berma de equilíbrio no Morro Preto (Machado Filho, 1984) 


\section{VIII.2. ESCORREGAMENTOS NA RODOVIA DOS IMIGRANTES - 1973/1976.}

Diversos ciclos de escorregamentos atingiram as encostas da Rodovia dos Imigrante durante sua construção, no período 1973-1976.

Vários pontos em condição de equilibrio-limite, já estavam naturalmente sujeitos a rupturas em época de chuva e tiveram sua instabilidade bastante agravada durante a execução das obras.

Partindo da premissa que deveriam ser evitadas excessivas instabilizações na Serra do Mar, o projeto da Rodovia dos Imigrantes previu uma estrada constituida de túneis e viadutos alternados, com os trechos de transição entre ambos construidos em cortes protegidos por cortinas atirantadas.

Ocorre que, para atingir as frentes de construção (emboques de túneis e fundações de viadutos), tiveram que construir previamente uma rede de estradas de serviço, com aproximadamente $21 \mathrm{~km}$ no seu trecho principal, alem de $17 \mathrm{~km}$ de ligações com os acampamentos de trabalhadores e canteiros de obras das empreiteiras (DERSA, Memória Técnica-20 anos, 1989). Essas estradas de serviço foram construidas básicamente em cortes à meia-encosta, afetando os solos superficiais mais instáveis (solo coluvial e tálus localizados). Assim sendo, desde 1972, com o trabalho dos tratores de lâmina que abriam esses acessos, essas encostas passaram a ser sistematicamente instabilizadas.

A verdade é que, com a premência de prazos, algumas diretrizes de projeto para a estrada de serviço não foram obedecidas, resultando na necessidade de muitos serviços corretivos de contenção, onerando grandemente os custos.

Como já mencionamos, ocorreram inúmeras instabilizações no decorrer da fase executiva da rodovia. Qualquer precipitação pluviométrica mais forte, especialmente as mais persistentes do período outubro/março, causavam temor, representando risco para os operários da obra. Felizmente e surpreendentemente, apenas um pequeno número de acidentes fatais ocorreu durante toda a construção da rodovia.

Em dezembro de 1975, a rodovia estava praticamente concluida, quando chuvas muito intensas provocaram novo ciclo de escorregamentos generalizados, afetando as estradas de serviço e atingindo a pista da Imigrantes em diversos pontos. Os serviços de contenção tiveram que ser retomados, postergando-se a inauguração da rodovia para $28 /$ junho/ 76 .

Dentre as instabilizações que afetaram diretamente a Rodovia dos Imigrantes, escolhemos duas bastante notáveis, localizadas em áreas muito problemáticas, que obrigaram à realização de obras de contenção de grande porte, para garantir a integridade da rodovia: 
Encosta do túnel TA-6, emboque S. Paulo.

Na estação chuvosa 1974/1975, um grande escorregamento seccionou cerca de $12 \mathrm{~m}$ da abóboda do TA-6, levando de roldão o escoramento primário em cambotas metálicas e concreto projetado. Tratava-se do desemboque do túnel, que avançava no sentido Santos-São Paulo, estando com a 1a. fase de escavação da abóboda concluida.

Os muros frontais e laterais desse emboque ainda não haviam sido executados, quando chuvas intensas incidiram sobre toda a região, provocando neste local uma ruptura profunda (com pelo menos $6 \mathrm{~m}$ ), condicionada pela existência de uma fenda de alívio de tensões sub-paralela ao talude (IPT, 1976).

As Fotografias VIII.2.1. e VIII.2.2., ilustram o caso apresentado.

A 1a. fotografia, tirada após a restauração do túnel, mostra o muro com cerca de 500 tirantes, que teve de ser executado na zona do escorregamento à montante do emboque. À juzante do mesmo, vê-se parte do material escorregado mais material de bota-fora, os quais ficaram depositados em condição instável, diretamente sobre a estrada de serviço.

A 2a. fotografia, tirada 1 ano depois, mostra o aspecto do tratamento vegetal realizado com sucesso para a contenção do material superficial acima referido. Foi utilizada uma técnica alternativa dos "cordóes vegetais", formando um retículo de vegetais com raízes pivotantes, preenchidos por leguminosas e gramíneas.

\section{Encosta do túnel TA-9, emboque S. Paulo.}

Essa encosta foi alvo de instabilizações recorrentes, em períodos chuvosos, sendo que, no evento 1974/1975, um grande escorregamento afetou a zona lateral próxima ao emboque, arrastando tanto o solo coluvial como parte do solo saprolítico.

Para conter o "frontão" formado na parte superior da cicatriz, o qual certamente evoluiria em novos escorregamentos, foram executadas 2 cortinas atirantadas escalonadas, acompanhando a morfologia do terreno, conforme ilustrado na

\section{Fotografia VIII.2.3.}

Foram executadas ainda, placas atirantadas na zona diretamente sobre o emboque $e$, placas atirantadas na zona lateral mais afastada, onde o maciço rochoso muito fraturado representava risco para os tubulóes do viaduto.

Foram realizados diversos drenos tubulares profundos (não visiveis na foto), distribuidos por toda a área, especialmente na zona da cicatriz do escorregamento, alem de canaletas de drenagem e escada hidráulica.

$\mathrm{Na} z o n a$ diretamente sobre o emboque, houve aplicação de concreto projetado, sendo que, em todo o restante da área, após o término do atirantamento procedeuse ao tratamento vegetal com hidrossemeadura. 


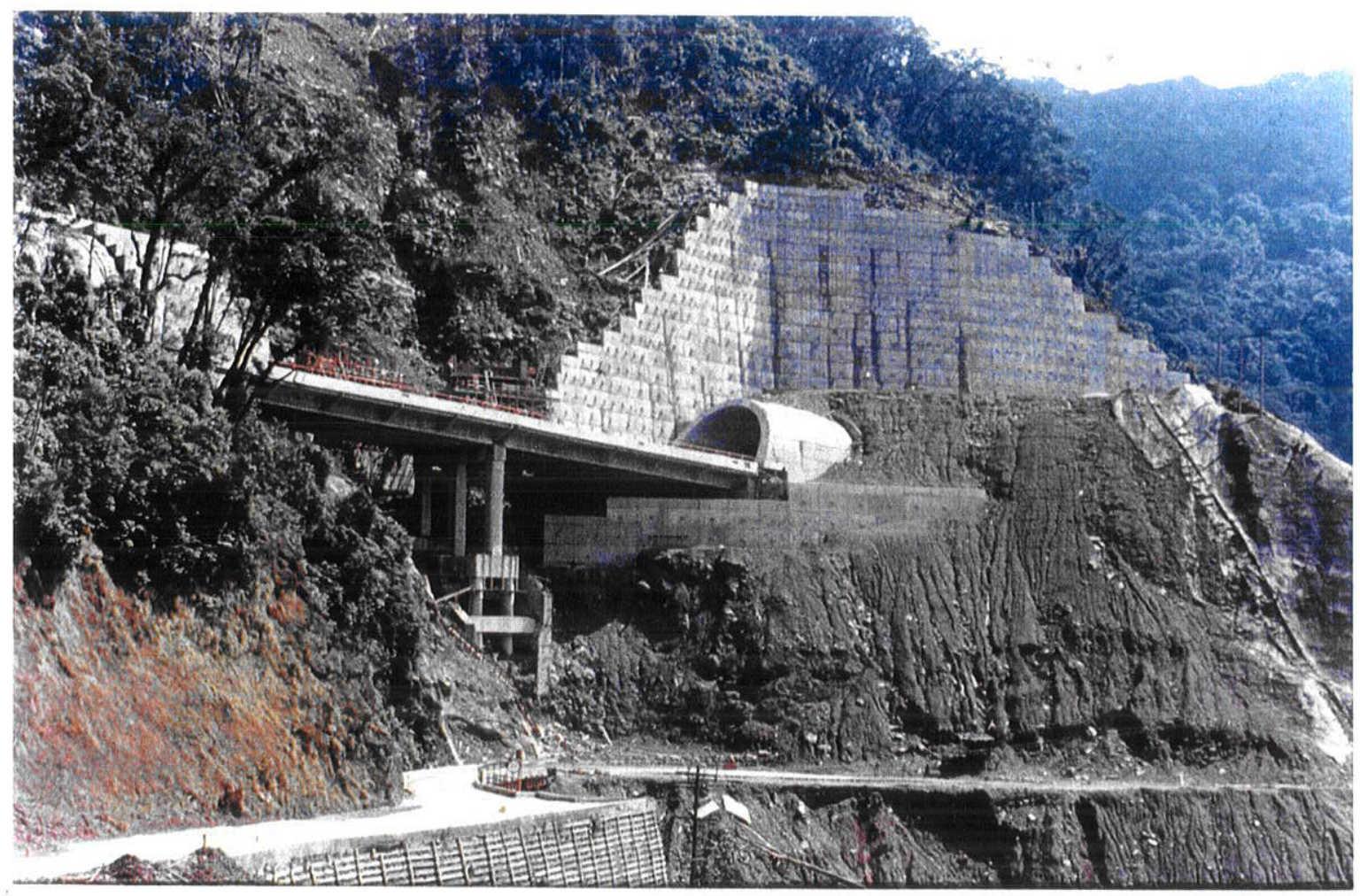

Fotografia VIII.2.1. Vista da encosta do TA-6, emboque S. Paulo (outubro/1975

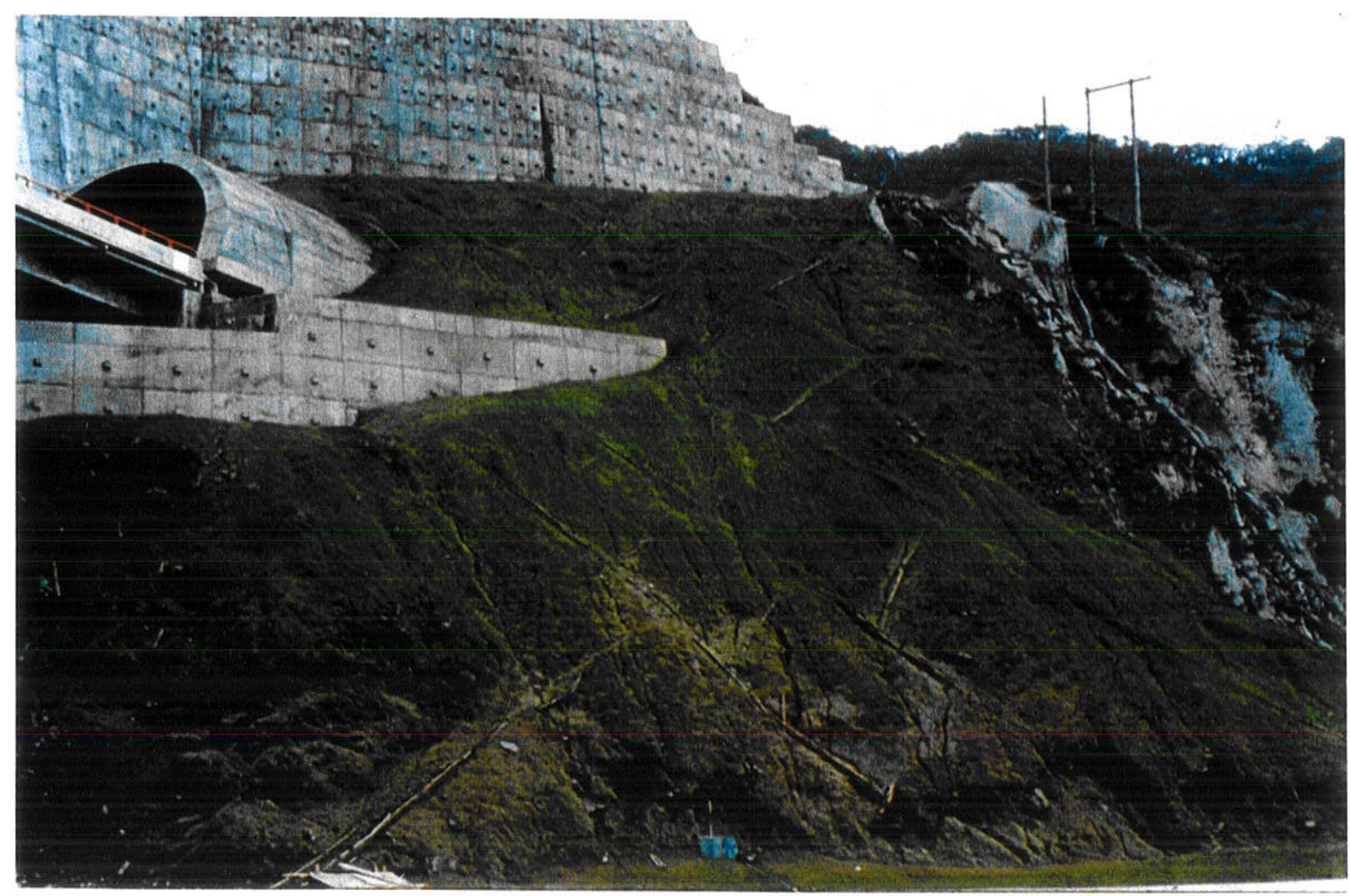

Fotografia VIII.2.2. Vista parcial à juzante do TA-6, emboque S. Paulo com tratamento vegetal (setembro/1976) 


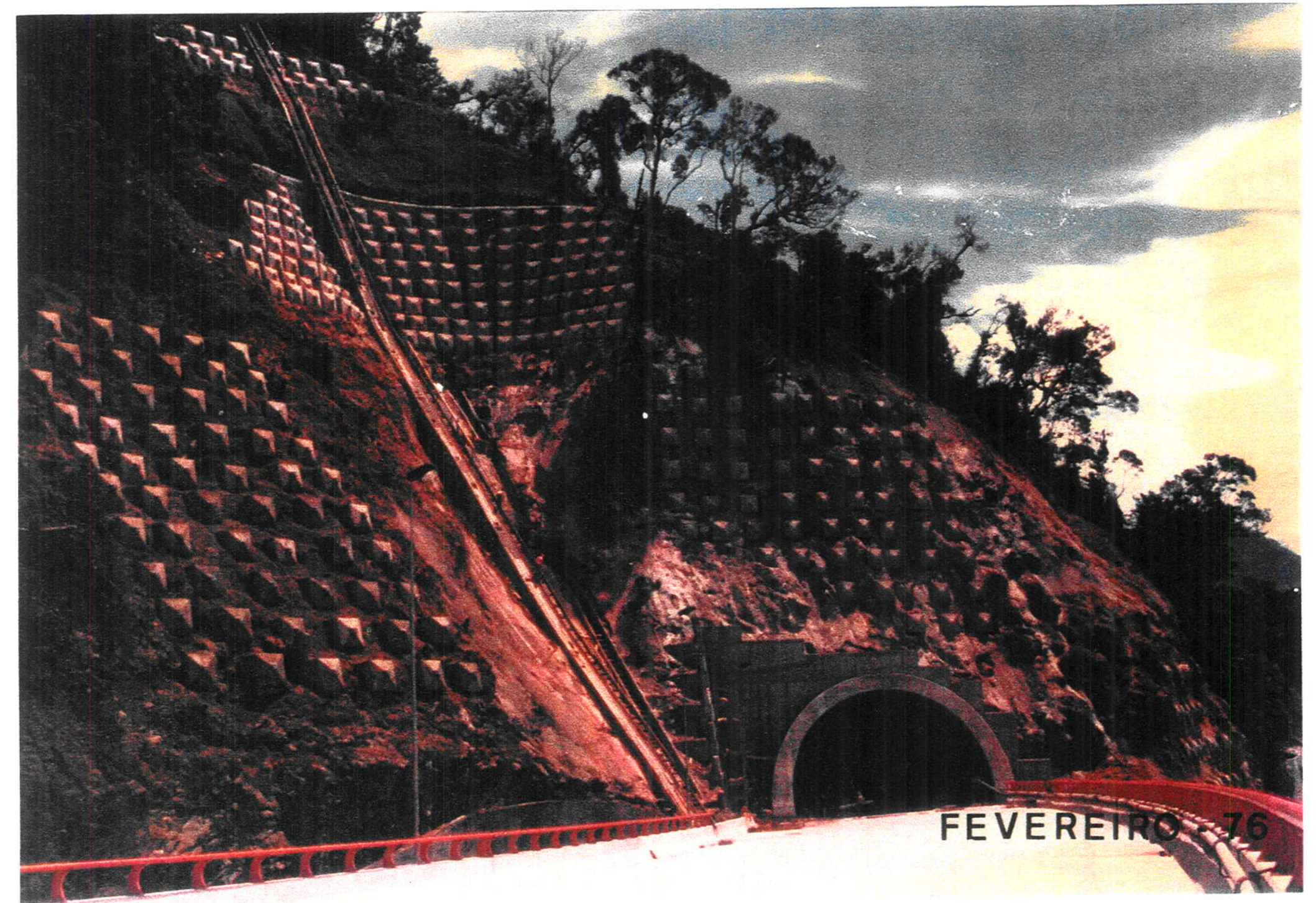

Fotografia VIII.2.3. Encosta do TA-9, emboque S. Paulo (DERSA, fevereiro/1976) 


\section{VIII.3. ESCORREGAMENTOS NO CAMINHO DO MAR - Fevereiro/94.}

Em 06 e 07 de fevereiro de 1994, chuvas excepcionais atingiram as encostas onde está localizado o Caminho do Mar, provocando a ocorrência de escorregamentos generalizados de solos e rochas em toda a área e danificando seriamente a rodovia. A rodovia foi seccionada em 2 pontos e sofreu danos de porte moderado a vultoso em outros 21 pontos ao longo de seu traçado (MACHADO FILHO, 1994).

Nesses dois dias de fevereiro, o índice pluviométrico alcançou a marca de $450 \mathrm{~mm}$, valor cerca de $60 \%$ superior à média mensal histórica para a região, causando principalmente rupturas nos solos superficiais. No processo desses escorregamentos, houve arraste de blocos rochosos dos talvegues, bem como rupturas rochosas localizadas.

O grande aumento de vazão d'água nas drenagens, provocou erosão dos seus leitos e bordas, com carreamento de solos e rochas. No seu trajeto descendente sob ação da gravidade, esse material atingiu diretamente a rodovia, que cruza transversalmente as drenagens principais.

Em vários pontos, observou-se tambem que a deficiência de manutenção das canaletas superficiais, ocasionou obstruções e concentrações de água sobre o leito da própria rodovia, resultando em erosões localizadas e rupturas na sua base.

A Fotografia VIII.3.1., corresponde a uma foto aérea das encostas do Caminho do Mar, localizadas no quadrante NE da área da pesquisa. Foi tirada em março de 1994, portanto logo após o evento chuvoso. Permite uma visão impressionante desses escorregamentos, que se iniciam na borda do Planalto Paulistano e se desenvolvem segundo um padrão linear dendrítico, cujos ramos maiores correspondem às drenagens principais que descem a escarpa.

A área central da foto, em forma aproximada de concha, está situada diretamente à montante da Refinaria Presidente Bernardes da PETROBRAS e, atravessando-a em toda sua extensão, vemos o Caminho do Mar, assinalado em linha colorida tracejada.

Nas Fotografias VIII.3.2. a VIII.3.4., são mostrados os pontos mais afetados da rodovia, em fotos tiradas pelo autor, em abril de 1994.

$\mathrm{Na}$ época em que ocorreu o evento, estudava-se a possibilidade de reabertura do Caminho do Mar, que encontra-se desativado desde 1979, para fins de turismo ecológico e cultural, já que a rodovia é patrimônio histórico tombado pelo CONDEPHAAT (Conselho de Defesa do Patrimônio Histórico, Arqueológico, Artístico e Cultural do Estado de São Paulo). 


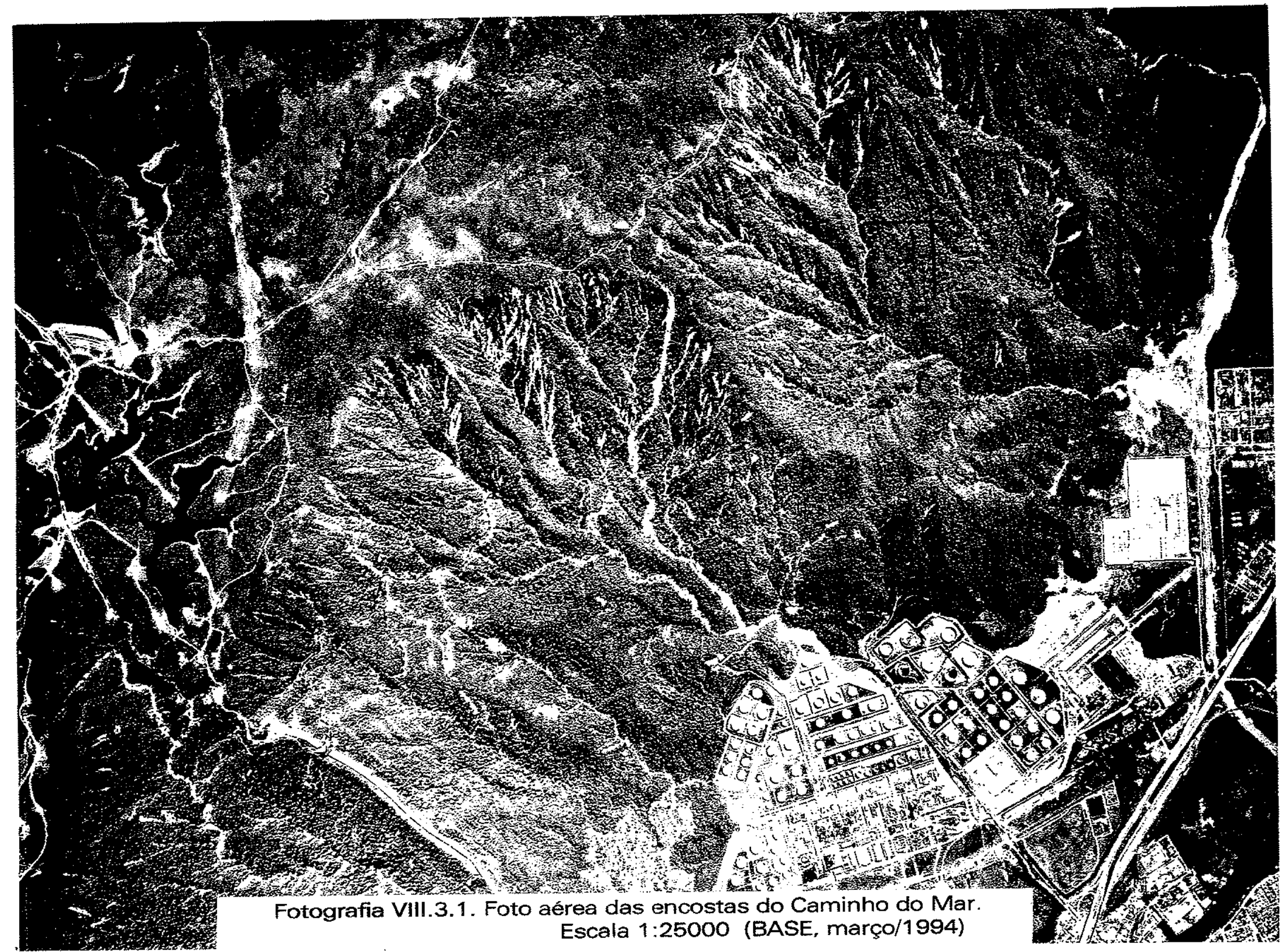




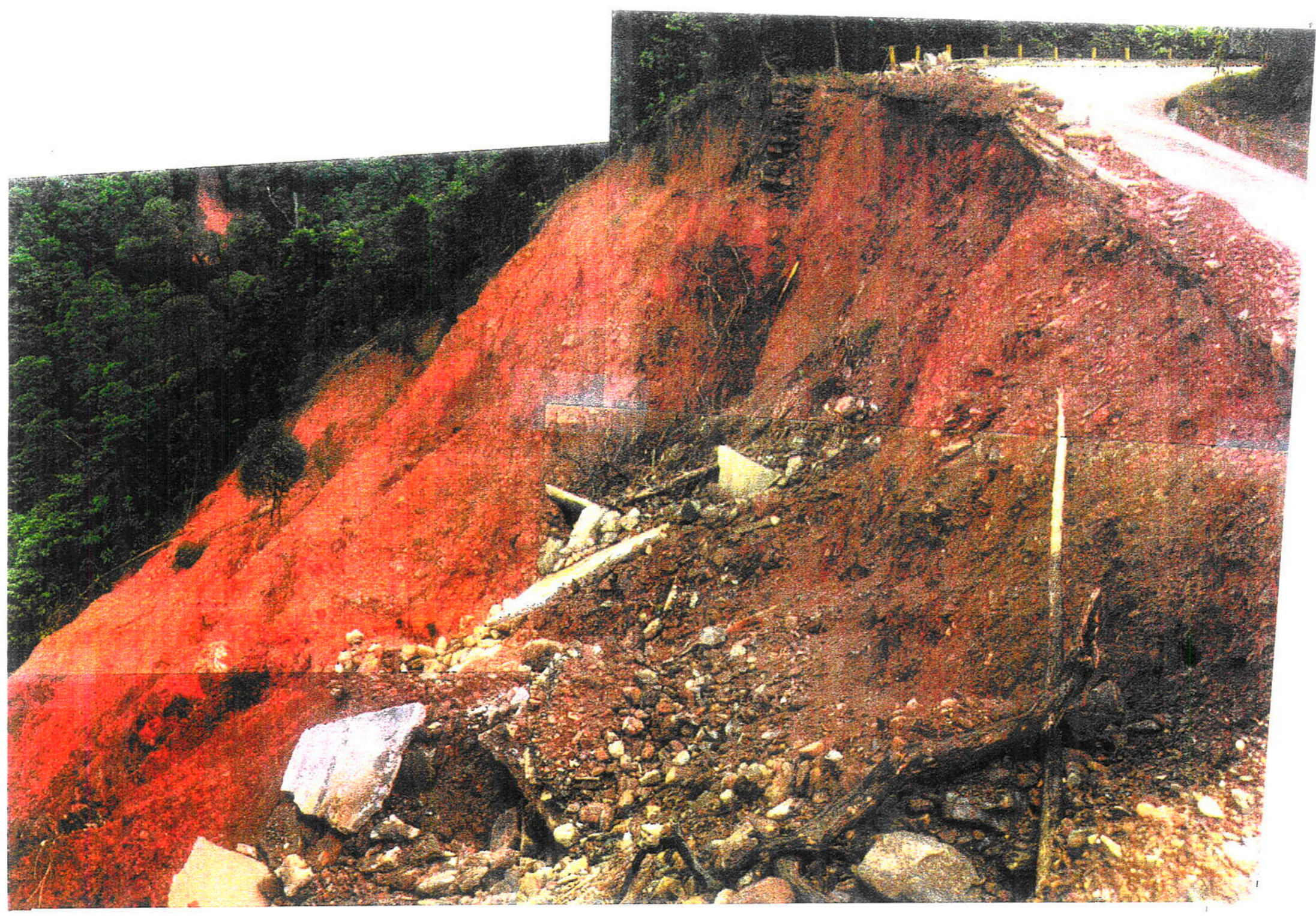

Fotografia VIII.3.2. Ruptura afetando meia pista no Caminho do Mar, km 47,6 (abril/1994) 


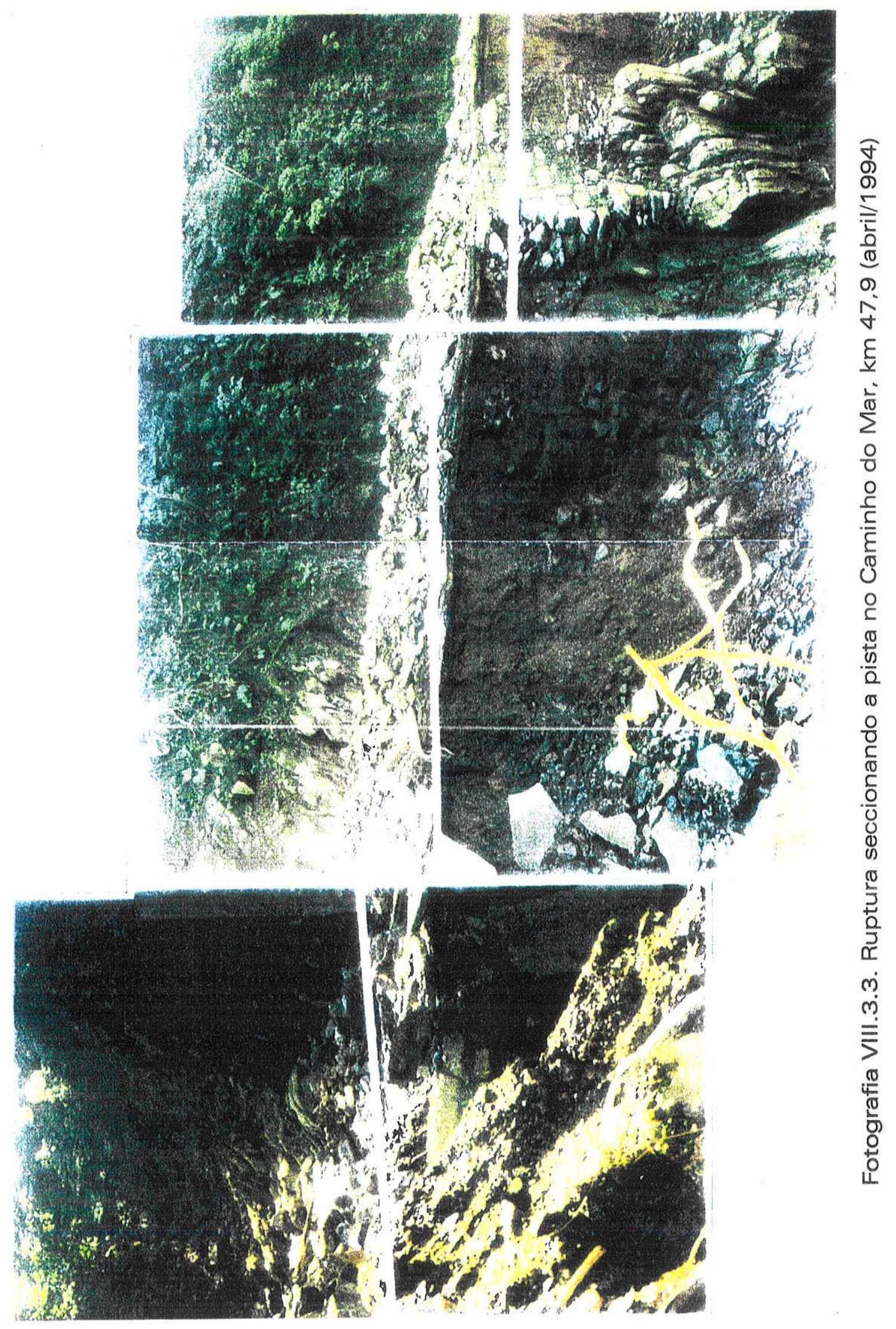




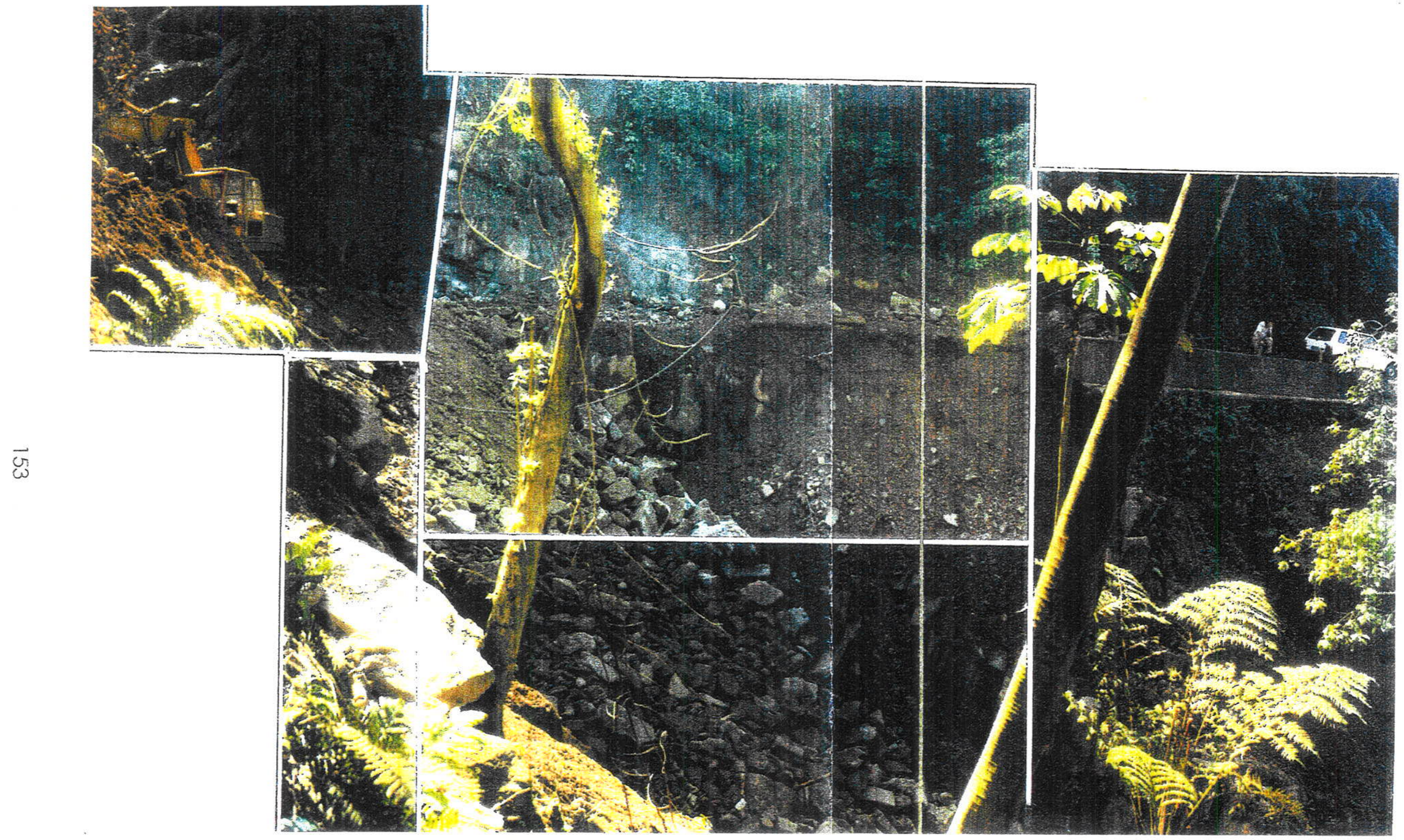

Fotografia VIII.3.4. Ruptura seccionando a pista no Caminho do Mar, km 48,1 (abril/1994) 
Houve início de tratativas entre diversos órgãos governamentais (DERSA, DAEE, CONDEPHAAT, SEMA, PETROBRAS), tendo em vista o potencial turísticoecológico-cultural, baseado na riqueza da biodiversividade da Mata Atlântica, bem como nas belíssimas paisagens da Serra do Mar e da Planície Costeira. Infelizmente, esse projeto foi posteriormente abandonado.

O Caminho do Mar, era anteriormente conhecido como Estrada Velha do Mar, sendo na verdade uma evolução da Estrada da Maioridade, construida em 1837 pelo Governador da Província de São Paulo, brigadeiro Rafael Tobias de Aguiar, aproveitando a antiga Calçada do Lorena.

A Estrada da Maioridade foi reconstruida em 1913, por Rudge Ramos e dez anos depois, Washington Luiz Pereira de Souza, então Presidente do Estado de São Paulo, determinou a sua melhoria e pavimentação em concreto, face à sua importância econômica como via de comunicação entre São Paulo e o Porto de Santos. Essa tarefa foi executada entre 1925 e 1926, dotando a estrada de excelentes condições para a época.

O Caminho do Mar permaneceu como a principal ligação rodoviária transpondo a Serra de Cubatão, até março de 1947, quando foi inaugurada a Via Anchieta, passando então a ser uma via alternativa. Com a inauguração da Rodovia dos Imigrantes, em junho de 1976, ele perdeu sua importância como via de transportes de cargas e passageiros e, devido aos altos custos de manutenção, foi desativado em 1979 (DERSA-Memória Técnica, 1989).

O evento de Fevereiro de 1994, apesar dos grandes prejuizos causados à rodovia, não causou acidentes fatais, uma vez que a estrada não estava aberta ao tráfego público, sendo usada apenas por pessoal técnico da DERSA, do DAEE e da PETROBRAS, empresas que mantem algumas instalações na região.

A partir de 1996, na tentativa de recuperação da estrada para fins ecológicoturísticos, vários pontos afetados foram restaurados, executando-se obras de estabilização de taludes, incluindo alguns muros atirantados, bem como limpeza geral e reparos nas canaletas de drenagem superficial.

Entretanto, as obras foram interrompidas por falta de verbas, quando faltava executar as duas obras mais vultosas, justamente as referentes aos locais ilustrados nas Fotografias VIII.3.3. e VIII.3.4., nos quais a estrada foi totalmente seccionada.

Certamente a grande concentração de escorregamentos nessa área, conforme pode-se ver na Fotografia VIII.3.1., teve como fator agravante a degradação da vegetação nessas encostas causadas pela poluição industrial proveniente do Polo Petroquímico de Cubatão, situado muito próximo, incluindo a refinaria visível na foto (GUTBERLET,1996). 
Antecedendo o Natal de 1999, fortes chuvas incidentes sobre a região, causaram ruptura na encosta do $\mathrm{km} \mathrm{42,} \mathrm{da} \mathrm{pista} \mathrm{sul} \mathrm{da} \mathrm{Via} \mathrm{Anchieta,} \mathrm{localizado} \mathrm{em} \mathrm{plena}$ Serra de Cubatão.

O escorregamento inicial na encosta, ocorreu em 12/12/1999, numa área localizada $80 \mathrm{~m}$ à juzante da pista da rodovia, com proporções de $100 \mathrm{~m}$ de largura por $200 \mathrm{~m}$ de extensão e atingindo $20 \mathrm{~m}$ de profundidade, ao longo do curso do vale do Rio Pilões (http//ecovias.uol.com.br), afetando os solos superficiais e o saprolito (Fotografia VIII.4.1.).

As chuvas intensas atingiram o valor de $481 \mathrm{~mm}$ em seis dias e, alem desse grande escorregamento, provocaram cerca de 30 outros, de menores proporções, na região da serra.

Devido ao escorregamento, houve movimentação da encosta na zona colocada imediatamente acima da cicatriz, provocando deslocamentos e fissuras num trecho de $150 \mathrm{~m}$ da Via Anchieta, que teve seu tráfego interrompido pela ECOVIAS (concessionária administradora do Sistema Anchieta-Imigrantes).

Os reparos emergenciais estavam em andamento, quando novas chuvas, em $23 / 12 / 1999$, causaram remobilização da encosta com a evolução remontante do escorregamento o qual atingiu diretamente a pista de rolamento (Fotografia VIII.4.2.).

O agravamento da situação mostrou a necesidade da realização de estudos geológico-geotécnicos detalhados, para uma avaliação técnica apurada do problema. Indicações técnicas preliminares indicam que a ruptura teve condicionamentos estruturais por descontinuidades no maciço.

Paralelamente à execução de um desvio rodoviário, o assunto passou a ser objeto de estudos de vários consultores contratados pela concessionária, visando estabelecer as melhores diretrizes para o projeto de estabilização do trecho afetado. Tratando-se de estudos em andamento, até o término do presente trabalho em março/2000, os dados técnicos detalhados estavam ainda em fase de avaliação, sendo mantidos em carater reservado pela concessionária.

A interdição da rodovia, justamente na época de férias escolares e feriados de Carnaval, causou transtornos ao já carregado tráfego entre São Paulo e Santos (e demais cidades litorâneas como Guarujá, São Vicente, Praia Grande, Itanhaem, etc.), reacendendo a discussão em torno da ocupação humana em áreas pertencentes ao "Parque Estadual da Serra do Mar", no qual está implantada a Via Anchieta.

O assunto amplamente divulgado pela mídia em geral, tornou inevitável a polêmica entre técnicos e ambientalistas, principalmente tendo em conta a construção, já em andamento na mesma época, da 2a. pista da Rodovia dos Imigrantes no trecho da serra, localizada tambem dentro do mesmo parque estadual. 


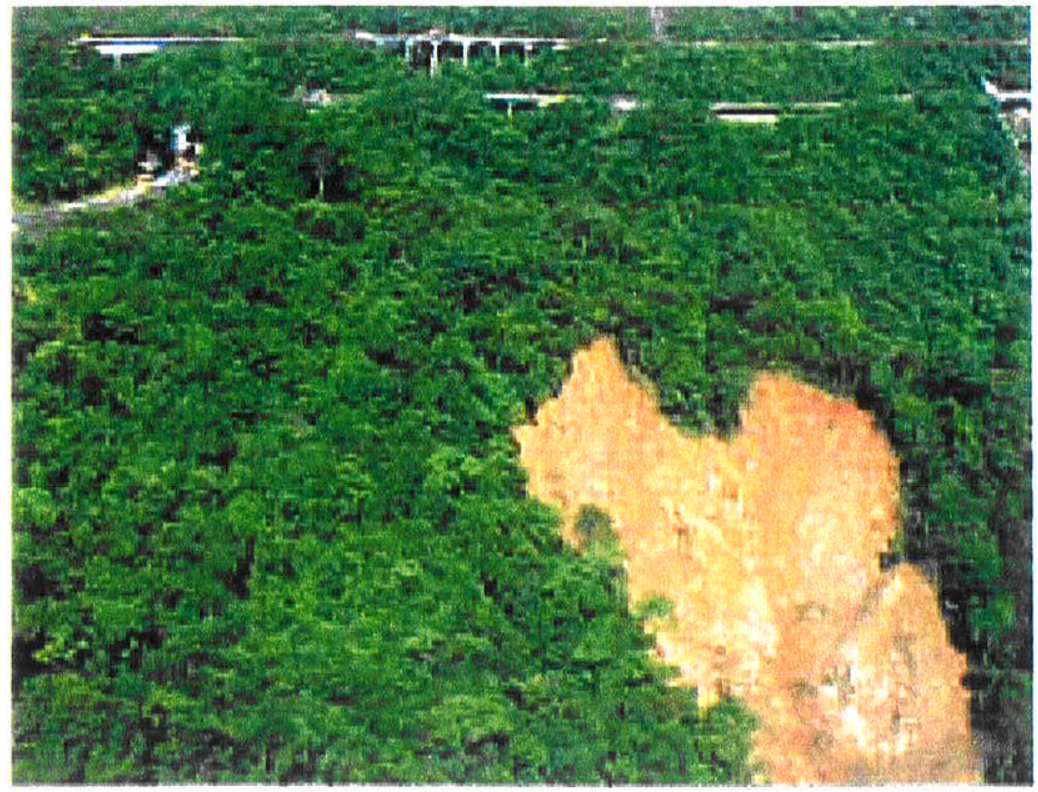

Fotografia VIII.4.1. Escorregamento inicial na Via Anchieta em 13/12/1999 (http://ecovias.uol.com.br)

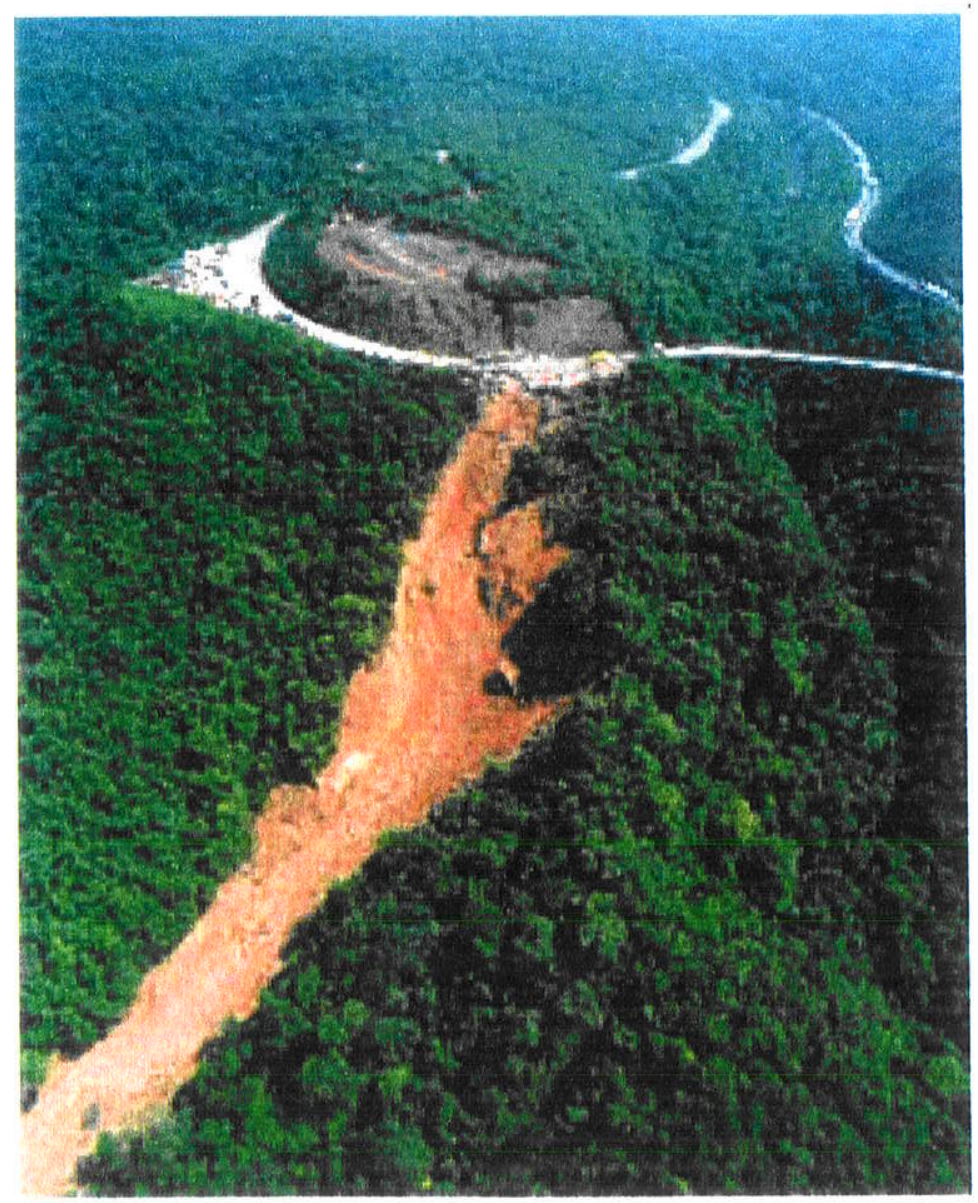

Fotografia VIII.4.2. Evolução do escorregamento em direção à pista em 23/12/1999 (http://ecovias.uol.com.br) 


\section{CAPÍtULO IX}

\section{CONCLUSÕES.}

1. A Serra de Cubatão, denominação local da Serra do Mar, tem sua origem íntimamente ligada à origem e desenvolvimento da costa sudeste brasileira, a qual se iniciou na era Mesozóica, no período Jurássico/Início do Cretáceo, há cerca de 140-120 milhões de anos, quando houve a separação dos blocos da América do Sul e África, que originalmente faziam parte do supercontinente do Gondwana.

2. A Falha de Cubatão, está inserida no contexto das megafalhas do sudeste brasileiro e tem sua origem remontando ao tectonismo do Ciclo Brasiliano, no final da era Proterozóica/Início da Paleozóica, entre 700 e 500 milhões de anos atrás. Esse sistema de falhamentos, conhecido como "Sistema de Megafalhas Cubatão", se manteve ativo desde sua origem Neo-Proterozóica, havendo indícios de rochas ígneas afetadas desde esse período até a era Mesozóica, alem de indícios de várias reativações tectônico-magmáticas posteriores, inclusive afetando sedimentos da era Cenozóica.

3. A Falha de Cubatão teve carater basicamente transcorrente dextral, com direção geral $\mathrm{N} 50^{\circ}-60 \mathrm{E}^{\circ}$, mostrando localmente evidências de cavalgamento.

As principais estruturas regionais e locais; dobramentos, falhamentos, foliações, intrusões graníticas, etc., se dispõem predominantemente segundo a mesma direção geral $\mathrm{N}^{\circ} 0^{\circ}-60 \mathrm{E}^{\circ}$.

4. Estruturas rúpteis, representadas por lineamentos estruturais e planos de descontinuidades, apresentam direções preferenciais concordantes com $\circ$ Falhamento de Cubatão ou sub-normais ao mesmo, sendo determinantes da formação e disposição das drenagens superficiais e profundas.

São claramente condicionantes da estabilidade geral das encostas, manifestando-se localmente nos horizontes estruturados saprolíticos e no maciço rochoso fraturado.

5. Os escorregamentos generalizados que ocorrem periodicamente nas estaçóes chuvosas de outubro a março, afetando especialmente os horizontes superficiais 
de solos coluviais, fazem parte integrante dos processos geomorfológicos naturais modeladores das escarpas da Serra de Cubatão.

6. A água das chuvas é o agente natural deflagrador desses escorregamentos cíclicos, saturando os solos e diminuindo sua resistência ao cizalhamento.

O processo é invariavelmente agravado pela ação antrópica, que muitas vezes é decisiva no deflagramento de eventos localizados, seja pela execução de obras, cortes $e$ abertura de acessos nessas encostas, seja pelo desmatamento $e$ ocupação inadequada.

7. O alívio erosivo e os movimentos de rastejo são característicos do trecho serrano da área pesquisada.

Os movimentos de rastejo, com seu deslocamento lento e contínuo, afetam não apenas os horizontes superficiais dos solos e tálus, onde são evidenciados pelo encurvamento dos caules das árvores, como os horizontes mais profundos de saprolito e rocha fraturada. Essa movimentação causa a abertura das juntas e descontinuidades, até dezenas de metros dentro do maciço rochoso, sendo diretamente responsável pelo padrão da drenagem subterrânea, basicamente vertical. Por essa razão, a não ser em zonas de tálus localizadas, o lençol freático não é encontrado no trecho serrano, mesmo na estação chuvosa, havendo rápida infiltração vertical no maciço fraturado. Isso, naturalmente, não impede que haja saturação dos solos superficiais, com perda substancial da sua coesão aparente.

8. Os escorregamentos mais comuns são do tipo superficial translacional, sendo a superfície de ruptura basicamente coincidente com o contacto solo coluvial/solo saprolítico.

No processo de escorregamento dos solos coluviais, observamos com alguma frequência, o arraste de partes do substrato saprolítico. Esses eventos periódicos, embora de pequena espessura, podem afetar extensas áreas, danificando a vegetação e causando cicatrizes de padrão linear-dendritico, visíveis a grandes distâncias. Nas chuvas mais persistentes, pode haver verdadeira liquefação dos solos, formando as "corridas de lamas", conforme documentado em alguns eventos catastróficos.

9. Escorregamentos localizados envolvendo saprolito e rocha fraturada, tem via de regra, o condicionamento estrutural de juntas e descontinuidades, apresentando 
portanto superfícies de ruptura planares e englobando espessuras de vários metros. O levantamento detalhado dessas estruturas é fundamental para a análise de cada caso.

10. Os tálus apresentam comportamento diferenciado quanto à estabilidade, dependendo das suas condições de localização, geometria, inclinação do substrato, constituição, posição do nível d'água, etc. De modo geral, são susceptíveis às poro-pressões ou pressões capilares resultantes da elevação sazonal do nível d'água em épocas chuvosas, o que favorece a ocorrência de rupturas, particularmente nos locais afetados por cortes, desmatamentos $e$ sobrecargas executadas pelo homem.

11. O movimento de rastejo nos tálus, apresenta comumente característica intermitente, acelerando-se ou reiniciando-se nos períodos chuvosos, provavelmente pela saturação e formação de pressões intersticiais. Essa característica foi evidenciada por monitoramento geomecânico na Rodovia dos Imigrantes, havendo variação de local para local, sendo que em vários deles os tálus se mostraram praticamente estabilizados.

12. A vegetação representa papel importante no travamento dos solos superficiais, formando uma trama que aumenta sua resistência à erosão e ao cisalhamento, ajudando ainda na distribuição das águas de infiltração das chuvas. Evidências disso, são a maior incidência de escorregamentos nas áreas desmatadas pelo homem para a execução de obras ou ocupação urbana.

Evidências tambem são encontradas nas encostas do Caminho do Mar, particularmente afetadas pelas chuvas ácidas causadas pela poluição industrial.

13. As estruturas rúpteis indicadas nos fotolineamentos, apresentam padrões diferenciados no Planalto e na Serra, devidos basicamente às suas diferentes extensões, que no planalto são de até poucas dezenas de metros e na serra atingem várias centenas de metros.

A análise de suas distribuições de frequência mostram que em ambos os casos se destacam dois sistemas direcionais principais:

$\mathrm{N} 50^{\circ}-60^{\circ}$ (concordante com a direção geral da Falha de Cubatão)

$\mathrm{N} 140^{\circ}-150^{\circ}$ (sub-normal à direção geral da Falha de Cubatão)

No caso do Planalto, ambos os sistemas são igualmente proeminentes, enquanto no caso da Serra o primeiro sistema prevalece sobre o outro. 
14. As Áreas A e B, separadas visualmente com base nos fotolineamentos, mostram tambem basicamente as mesmas direções preferenciais, quando analisadas através dos diagramas de distribuição de frequência. Entretanto, existe evidente proeminência de um sobre o outro, em cada área:

$\mathrm{Na}$ Área $\mathrm{A}$, o sistema principal é $\mathrm{N} 55^{\circ}$ e o secundário $\mathrm{N} 145^{\circ}$. Na Área $\mathrm{B}$, ocorre uma inversão, sendo $\mathrm{N} 145^{\circ}$ o sistema principal e $\mathrm{N} 55^{\circ}$ o sistema secundário.

15. Os pontos $\mathrm{A} 1, \mathrm{~A} 2$, na área $\mathrm{A}$ e $\mathrm{B} 1, \mathrm{~B} 2, \mathrm{~B} 3$, na área $\mathrm{B}$, escolhidos para detalhamento das descontinuidades, permitem algumas considerações:

- A foliação da rocha condiciona a formação dos principais planos de descontinuidades;

- Existe uma boa correspondência entre as direções das juntas e as dos fotolineamentos. Essa correspondência entretanto não é direta, sendo que as juntas principais ora concordam com os fotolineamentos principais, ora com os fotolineamentos secundários;

- Quatro pontos (exceto B1), mostram familias de juntas principais segundo $\mathrm{N} 45^{\circ}-60^{\circ}$, com mergulhos superiores a $75^{\circ}$ para NW. Essa condição é favorável à estabilidade das encostas, embora não deva ser analisada isoladamente;

- Quatro pontos (exceto B2), mostram familias secundárias segundo N $125^{\circ}$ $146^{\circ}$, com mergulhos superiores a $57^{\circ}$ para $\mathrm{NE}$, as quais consideradas isoladamente tambem não constituem condição desfavorável;

- As juntas mais desfavoráveis para a estabilidade são as representadas pelas famílias secundárias em A1, B1, B2, com direção entre $\mathrm{N} 20^{\circ}-85^{\circ}$ e mergulhos entre $36^{\circ}-41^{\circ}$ para SE.

16. Considerando que a direção geral da escarpa serrana é $\mathrm{NE}$, com forte declividade para SE, constituem situações de risco potencial de ruptura, a ocorrência de planos de descontinuidades tangentes aos taludes e com mergulhos superiores a $30^{\circ}$ para $\mathrm{SE}$, que podem superar o valor do ângulo de atrito do material da encosta.

$\mathrm{Na}$ verdade, devido às reentrâncias do relevo, representadas por ravinamentos e drenagens, os taludes locais podem apresentar outras atitudes espaciais. Em qualquer caso porem, ocorre a condição de risco para ruptura, se existirem descontinuidades tangentes ao talude e com ângulos de mergulho superiores a $30^{\circ}$, no mesmo sentido da declividade. 
17. Sendo as camadas superficiais as mais susceptiveis aos escorregamentos, em todas as obras de encosta devem ser tomados cuidados especiais com os dispositivos de drenagem superficial, como canaletas, bueiros, caixas de captação, dissipadores e escadas hidráulicas, etc., evitando erosões localizadas que possam dar início aos processos de instabilização.

Tendo em vista ainda, que o padrão da drenagem subterrânea no maciço da serra é predominantemente vertical, a execução de drenos profundos deve ficar restrita às situações onde eles possam realmente ser eficientes, como as verificadas em certas regióes de tálus, incluindo o seu contacto com o substrato, alem de alinhamentos de falhas e fraturas funcionando como zonas de percolação concentrada de água.

18. Devido à alta pluviosidade da região $e$, sendo a chuva $\circ$ principal agente natural instabilizador das encostas, a execução de qualquer tipo de obra no trecho serrano deve ser baseada em cronograma que leve em consideração a estação chuvosa de outubro a março.

Os meses de junho a agosto são os de menor pluviosidade, sendo os mais favoráveis para essas atividades, enquanto os períodos de passagem de ano (dezembro/janeiro) tem-se mostrado particularmente problemáticos, com a ocorrência de rupturas e escorregamentos, provocados por chuvas intensas generalizadas ou concentradas em determinadas áreas. 


\section{REFERÊNCIAS BIBLIOGRÁFICAS}

ASSOCIAÇÃO BRASILEIRA DE GEOLOGIA DE ENGENHARIA (1974). Condicionantes geológicos e geotécnicos da degradação ambiental. Vários autores. Bol. ABGE, 1, 11 p.

ASSOCIAÇÃO BRASILEIRA DE GEOLOGIA DE ENGENHARIA (1998). Geologia de engenharia. Vários autores., São Paulo, ABGE/CNPQ/FAPESP, 586p.

AB'SABER, A. N. (1965). A Serra do Mar e o Litoral de Santos. Bol. Acad. Bras. Ciênc., 37:396-397.

ALMEIDA, F. F. M. (1953). Considerações sobre a Geomorfogênese da Serra de Cubatão. Bol. Paul. Geogr., 15:3-17.

ALMEIDA, F. F. M. (1964). Fundamentos geológicos do relevo paulista. Bol. Inst. Geogr. Geol.41:169-263.

ALMEIDA, F. F. M. (1967). Origem e evolução da plataforma brasileira. Rio de Janeiro, DNPM/DGM, 241: 36p.

ALMEIDA, F.F.M. (1976). The system of continental rifts bordering the Santos basin, Brazil. In: Acad. Bras. Ciênc., 48 (suplemento):15-26.

ANDRADA, M.F.R. (1954). Diário de uma viagem mineralógica pela Província de São Paulo no ano de 1805. Bol Paul. Geogr., 18:34-44.

ANGELIER. J. e MECHLER, P. (1977). Sur une méthode graphique de recherche des contraintes principales également utilisable en tectonique et en seismologie: la méthode des dièdres droits. Bull. Soc. Géol. France, 7:1309-1318.

ARTHAUD, E. (1969). Méthode de determination graphique des directions de raccourcissement, dállongement et intermediaire d'une population de failles. Bull. Soc. Géol. France., 7:729-737 (théme 11). 
ASMUS, H.E. (1978). Hipótese sobre a causa do tectonismo cenozóico na região sudeste do Brasil. Projeto Remac, 4, p.75-88.

ASMUS, H.E. (1982). Características estruturais e estratigráficas da margem continental brasileira como elementos críticos de sua evolução. In: CONGRESSO LATINO AMERICANO DE GEOLOGIA, 5, Buenos Aires, v. 3, p.781-798.

ASMUS, H.E. e PORTO, R. (1980). Diferenças nos estágios iniciais da evolução da margem continental brasileira: possiveis causas e implicações. In: CONG. BRASILEIRO DE GEOLOGIA , 31, Camboriú, SBG, v. 1, p. 225-239.

AUGUSTO FILHO, O. (1992). Caracterização geológica-geoténica voltada à estabilização de encostas: uma proposta metodológica. In: CONFERÊNCIA BRASILEIRA SOBRE ESTABILIDADE DE ENCOSTAS, Rio de Janeiro. v. 2, p.721-733.

AUGUSTO FILHO, O. (1994). Cartas de risco e escoregamentos: uma proposta metodológica e sua aplicação no município de Ilha Bela, SP. Dissertação de mestrado, 168p. Esc. Politécnica da Universidade de São Paulo.

BADGLEY, P.C. (1992). For the exploration geologist. New York, Harper \& Brothers.

BARTON, N.; LIEN, R.; LUNDE, J. (1974). Engineering classification of rock masses for design of tunnel support. Rock Mech., v.6, n.4.

BAULIG, H. (1956). Vocabulaire franco-angloallemand de géomorphologie. Paris, Les Belles Lettres, 230p.

BENIAWSKI, Z. T. (1989). Engineering rock mass clasification. New York: John Wiley.

CARVALHO, P.A.S. (Coord.) (1991). Taludes de rodovias: orientação para diagnósticos e soluções de seus problemas. São Paulo, IPT, Publicação nº. $1843,410 \mathrm{p}$. 
CAMPANHA, G.A.; ENS, H.H. e PONÇANO,W.L. (1994). Análise morfotectônica do planalto do Juqueriquerê, São Sebastião. Rev. Bras. Geoc., 24(1):32-42.

CERNICA, J.N. (1995). Geothecnical engineering - soil mechanics. New York, John Wiley, 453p.

CHANG, H.K.; KOWSMANN, R.O.; FIGUEIREDO, A.M.F.; BENDER, A.A. (1992). Tectonics and stratigraphy of the East Brasil Rift system: an overview. Tectonophysics, 213:97-138.

CHORLEY, R.J.; SCHUMM, S.A.; SUDGEN, D.E. (1984). Geomorphology. London, Methuen, $605 \mathrm{p}$.

CORDANI, U.G.; BRITO NEVES, B.B.; FUCK, R.; PORTO, R.; THOMAZ FILHO, A.; CUNHA, F.M.B. (1984). Estudo preliminar de integração do Precambriano com os eventos tectônicos das bacias sedimentares brasileiras. Ser. Ciênc., Tec. Petr., PETROBRAS/CENPES/SINTEP, 15, $70 \mathrm{p}$.

CRUZ, O. (1975). Evolução de vertentes nas escarpas da Serra do Mar em Caraguatatuba. In: Acad. Bras. Ciências, Rio de Janeiro, 47 (supl.):479-480.

CRUZ, O . (1990). Contribuição geomorfológica ao estudo de escarpas da Serra do Mar. Rev. Inst Geogr., 8-10, 11 (1):9-20.

DEPARTAMENTO DE ÁGUAS E ENERGIA ELÉTRICA (1997). Totais mensais de chuva no Estado de São Paulo. São Paulo, DAEE/CTH.

DE MARTONNE, E. (1933). Abruptes de Faille et Captures Rècentes -"Serra do Mar de Santos e Espinausses”. Bol. Assoc. Geogr. da França, Paris, 74:138-145.

DEERE, D. U. et al (1967). Design of surface and near - surface construction in rock, in failure and breakage of rock. New York, Aime.

DEERE, D. U. e PATTON (1971). Slope stability in residual soils. State of de art paper. In: PANAMERICAN CONFERENCE ON SOIL MECHANICS AND FOUNDATION ENGINEERING 
DEPARTAMENTO DE ESTRADAS DE RODAGEM DO ESTADO DE SÃO PAULO (1947). A Via Anchieta. São Paulo, DER, 47p.

DESENVOLVIMENTO RODOVIÁRIO SA (1989). Memória Técnica - 20 anos, 19691989. São Paulo, DERSA, 288 p.

EGYDIO DA SILVA, M.; SADOWSKI, G.R.; TROMPETE, R.R. (1982). Modelo geométrico e cinemático para os falhamentos de idade brasiliana da faixa de dobramento Ribeira - Estado de São Paulo - Brasil. In: CONGRESSO LATINO AMERICANO DE GEOLOGIA, 5, Argentina, v. II, p. 11-21.

ENDO, I \& MACHADO, R. (1993). Sistema de cizalhamento transatlântico: um modelo tectônico transpressional para o neoproterozóico do Brasil oriental. In: SIMPÓSIO NACIONAL DE ESTUDOS TECTÔNICOS, 4, Belo Horizonte, Bol. 12, p. 356-359.

ESCRITÓRIO TEC. J. C. F. FERRAZ; ALPINA SPA. (1971). Rodovia dos Imigrantes, Projeto de Engenharia, Trecho Serra, Relatório Geral, São Paulo, DERSA.

ESTRELLA, G. O. (1972). O estágio de rift nas bacias marginais do leste brasileiro. In: CONGRESSO BRASILEIRO DE GEOLOGIA, Belém, SBG, v. 3, p. 29-34.

GAMA, C.D. (1982). Avaliação probabilística da estabilidade de taludes. In: CONGRESSO BRASILEIRO DE MECÂNICA DE SOLOS, 7, Recife, ABMS, v. 1, p. 59-74.

GEOTÉCNICA S.A. (1968). Estudos geológico-geotécnicos para o anteprojeto da Rodovia dos Imigrantes-variante Sorocabana. São Paulo, Relatório 260/68.

GONÇALVES, A.C. (1995). Recomposição florística de área de escorregamento. São Paulo, DERSA, Relatório técnico, 45p.

GRAY, D. H. \& LEISER, A.J. (1982). Role of vegetation in stability and protection of slopes. In: BIOTECHNICAL SLOPE PROTECTIONAL AND EROSION CONTROL, New York. P., p.37-65. 
GUIDICINI, G \& NIEBLE, C.M. (1976). Estabilidade de taludes naturais e de escavação, São Paulo. Editora da USP, 170p.

GUIDICINI, G \& IWASA, O.Y. (1976). Ensaio de correlação entre pluviosidade e escorregamentos em meio tropical úmido. São Paulo. IPT, Publicação $\mathrm{n}^{\circ} .1080,48 \mathrm{p}$.

GUTBERLET, J. (1996). Cubatão-desenvolvimento, exclusão social, degradação ambiental. São Paulo, Editora da USP, 242p.

HASUI, Y. \& SADOWSKI, G.R. (1976). Evolução geológica do Precambriano na região sudeste do Estado de São Paulo. Rev. Bras. Geoc., 6:182-200.

HASUI, Y.; PONÇANO, W.L.; BISTRICHI, C.A.; STEIN, D.P.; GALVÃO, C.A.C.F.; GIMENEZ, A F.; ALMEIDA, M.A.; PIRES NETO, A.G.; MELO, M.S.; SANTOS, M.C.S.R. (1978). Geologia da região administrativa 3, Vale do Paraiba e parte da região administrativa 2 do Estado de São Paulo. São Paulo, IPT, Monografia 1, 78p.

HASUI, Y. \& OLIVEIRA, M. A. F. (1984). Província Mantiqueira - setor central. In: O Precambriano do Brasil, $1^{a}$ ed., São Paulo. Ed. E. Blücher, p. 308-344.

HASUI, Y. \& MIOTO, J.A. (1992) Geologia Estrutural Aplicada. São Paulo, ABGE/VOTORANTIM, 459p.

HATCHER JUNIOR, R.D. (1995). Structural Geology principles. New Jersey, Prentice Hall.

HESSING, J.M. (1976). Estudos geotécnicos no trecho serra da Rodovia dos Imigrantes. In: SEMINÁRIO DERSA-RODOVIA DOS IMIGRANTES, 1, São Paulo, DERSA, p. 31-46.

HOEK, E. (1972). Estimando a estabilidade de taludes escavados em minas a céu aberto. Trad. de C.M. Nieble. São Paulo, APGA, 58p.

HOEK, E. \& LONDE, P. (1974). Surface workings in rock. In: INTERNATIONAL CONGRESS ON ROCK MECHANICS, Denver, v.1, p. 613-654. 
HOEK, E. \& BRAY, J. W (1997). Rock slope engineering. London, IMM, 358p.

HOEK, E. \& BROWN, E.T. (1996). Underground Excavation in Rock, London, IMM, $527 p$.

HUTCHINSON, J.N. (1988) General Report: Morphological and geotechnical parameters of landslides in relation to geology and hydrogeology. In: FIFTH INTERNATIONAL SYMPOSIUM ON LANDSLIDES, Lauzanne, v. 1, p. 3-35.

INSTITUTO GEOLÓGICO-INSTITUTO DE PESQUISAS TECNOLÓGICAS (1994). Plano preventivo de Defesa Civil-PPDC - Específico para escorregamentos no Litoral Norte e Baixada Santista. São Paulo, Coord. Est. de Defesa Civil.

INSTITUTO DE PESQUISAS TECNOLÓGICAS (1968). Estudo geológico preliminar da Variante Anchieta do Ramal de Santos - Estrada dos Imigrantes. São Paulo, IPT, relatório n 4939.

INSTITUTO DE PESQUISAS TECNOLÓGICAS (1968). Estudo geológico complementar do trecho Planalto-Pilóes da Variante Anchieta do Ramal de Santos - Estrada dos Imigrantes. São Paulo, IPT, relatório nº 5169.

INSTITUTO DE PESQUISAS TECNOLÓGICAS (1976). Estudo geológico-geotécnico de dois conjuntos maciço-túnel na Rodovia dos Imigrantes. São Paulo, IPT, relatório $\mathrm{n}^{\circ} 9086$. v. $1,80 \mathrm{p}$.

INSTITUTO DE PESQUISAS TECNOLÓGICAS (1990). Software de estabilidade de taludes aplicados à geotecnia e mineração. São Paulo, IPT, relatório n ${ }^{\circ}$ 28.235 .

INSTITUTO DE PESQUISAS TECNOLÓGICAS (1991). Ocupação de encostas. São Paulo, IPT, Manual, 216p.

KLEY, R.J. \& LUTTON, R. J. (1967). Engineering properties of nuclear craters. Report U.S. Army Engineering, 159p.

KNECHT, T. \& MONBEIG, P. (1936). Excursão ao trecho da estrada Mairink-Santos. Rev. Geografia, São Paulo, 213:73-79. 
KÖPPEN, W. (1918). Klassifikation der klimate nach temperatur. Peterm, Geogr. Mitt., 64:193-203 e 243-248. Die Klimate der Erde, Berlin/Leipzig, 1923.

LEINZ, V. \& LEONARDOS, O. (1971). Glossário Geológico. São Paulo, Edit da USP, $236 \mathrm{p}$.

MACCAFERRI OFFICINE SpA (1979). Gaviones. Bologna, 86p.

MACHADO FILHO (1969). Aplicação da eletro-resistividade na Rodovia dos Imigrantes. In: SEMANA PAULISTA DE GEOLOGIA APLICADA, 1, São Paulo, APGA, v. III, IX1-IX22.

MACHADO FILHO, J. G. (1974). Camisas cilíndricas de concreto protegem viadutos na Rodovia dos Imigrantes. Rev. Engenharia, São Paulo, 368:34-42.

MACHADO FILHO, J. G. \& HESSING, J.M. (1976). Considerações sobre os estudos geológicos realizados em diversas fases na Rodovia dos Imigrantes, trecho serra. In: SEMINÁRIO DERSA-RODOVIA DOS IMIGRANTES, 1, São Paulo, DERSA, p. 320-329.

MACHADO FILHO, J. G. (1976).Tirantes de injeção - sistemática de utilização. In: CONGRESSO BRASILEIRO DE GEOLOGIA DE ENGENHARIA, 1, Rio de Janeiro, ABGE, v.1, p.35-55.

MACHADO FILHO, J.G. \& RODRIGUES, R. (1984). A Ocupação humana em áreas instáveis da Via Anchieta. In: CONGRESSO BRASILEIRO DE GEOLOGIA DE ENGENHARIA, 4, Belo Horizonte, ABGE, v. 2, p. 59-80.

MACHADO FILHO, J. G. (1994). Diagnóstico e cadastramento geotécnico do Caminho do Mar. - Comissão do Caminho do Mar. Relatório Técnico. São Paulo, DERSA, junho/94, 160p.

MARSHAK, S. \& GAUTAM, M. (1986). Basic methods of structural geology. Englewood, USA, Prentice Hall.

MORAES REGO, L. F. (1940). A geologia do Estado de São Paulo. São Paulo, Separata do Boletim DER, p. 153. 
NAKAZAWA, V. A \& CERRI, L.E.S. (1990). Os escorregamentos ocorridos em Petrópolis, RJ, em fevereiro de 1988: ações emergenciais. In: SIMPÓSIO LATINO AMERICANO DE RISCO GEOLÓGICO URBANO. São Paulo, ABGE, p. 325-333.

NUNES, A.J.C.; FERNANDES, C.E.M.; ILIESCO, M.; CID, M.R.V.K.; ALVES, R.I.V.; SILVA, L.J.R.D.B. (1990). Contribuição ao conhecimento do risco geológico da cidade de Petrópolis, RJ. In: SIMPÓSIO LATINO-AMERICANO SOBRE RISCO GEOLÓGICO URBANO. São Paulo, ABGE, p. 102 -114.

PALMA, J.J.C.; FRANÇA, A.M.C.; ZEMBRUSCKI, S.J. (1979). Brasil - margem continental. PETROBRAS, Projeto Remac (Physiographic map).

PASTORE, E.L. (1995). Weathering profiles. In: PANAMERICAN CONFERENCE ON SOIL MECHANICS AND FOUNDATION ENGINEERING. Guadalajara, ISSMFE, v. 1, p. 353-364.

PATTON, F.D. \& HENDRON JUNIOR, A.J. (1974). General report on mass movements, São Paulo. In: INTERNATIONAL CONGRESS OF THE IAEG,1, São Paulo, ABGE/IAEG, v. 2, p. 1-57.

PICHLER, E. (1957). Aspectos geológicos dos escorregamentos de Santos. São Paulo, Bol. SBG, v. 6, n² 2 .

PITEAU, D.R. \& MARTIN, D.C. (1981). Mechanics of rock slope failure. In: INTERNATIONAL CONFERENCE ON STABILITY IN SURFACE MINING. Vancouver, p. 113-169.

PRANDINI, F.L; GUIDICINI, G.; BOTTURA, J.A.; PONÇANO, W.L.; SANTOS, A.R.. (1976). Atuação da cobertura vegetal na estabilidade de encostas: uma resenha crítica. São Paulo, IPT, Publicação especial nº 1074, 22p.

RAMSEY, J.G. \& HUBER, M.I. (1987). The techniques of modern structural geology. London, Academic Press. 
RICCOMINI, C.; APPI, C.J.; FREITAS, E.L.; ARAI, M. (1987). Tectônica e sedimentação no sistema de rifts continentais da Serra do Mar (bacias de Volta Redonda, Resende, Taubaté e São Paulo). In: SIMPÓSIO DE GEOLOGIA, RJ-ES, 1, Rio de Janeiro, SBG, p. 253-298.

RICCOMINI, C. (1989). O rift continental do sudeste do Brasil. Tese de doutoramento, 256p. São Paulo, Instituto de Geociências, USP.

ROBERTS, A. (1977). Geotechnology - An Introductory Text for Students and Engineers. Oxford, PergamonPress

RODRIGUES, J. C. \& NOGAMI, J. S. (1951) Geologia do Escorregamento da Cota 95 da Via Anchieta. In: CONGRESSO NACIONAL DE ESTRADAS DE RODAGEM, VIII, Seção II, DNER.

RODRIGUES, R. (1992). Características geológicas e geotécnicas intervenientes na estabilidade de massas coluviais da Serra de Cubatão. Dissertação de mestrado, 116p. Escola de Engenharia de São Carlos, USP.

ROMANA, M. R. (1985). New adjustment ratings for application of Beniawski classification to slopes. In: INT. SYMP. ON LANDSLIDES, Lausanne.

ROSS-BROWN, D.R. (1973). Slope design in opencast mines. Ph.D.Thesis, 250p. London, Imperial College.

ROWLAND, S. M. (1986). Structural analisys and synthesis. Palo Alto, USA: Blackwell Scientific Publications, 210p.

RUELLAN, F. (1957). Aspectos geomorfológicos do Litoral Brasileiro no trecho entre Santos e Rio Doce. São Paulo, Bol. Assoc. Geógr. Bras., 15:6-12.

SADOWSKI, G.R. (1974). Tectônica da serra de Cubatão. Tese de doutoramento, 131p. São Paulo, Instituto de Geociências, USP.

SADOWSKI, G.R. (1977). Reativação do embasamento da faixa de dobramento Ribeira na região da Serra do Cubatão. Bol. Inst. Geoc. USP, 8:67-76. 
SADOWSKI, G.R. \& MOTIDOME, M.J. (1987). Brasilian megafaults. Rev. Geol. de Chile, 31:61-75.

SADOWSKI, G.R. (1991). A megafalha de Cubatão no sudeste brasileiro. Bol. Inst. Geoc., USP, 22:15-28

SADOWSKI, G.R (1992). A aplicação de sistemas geográficos de informação em mapeamentos geológicos e geotécnicos. In: CONGRESSO BRASILEIRO DE GEOLOGIA, 37, São Paulo. Bol. Res. Expandidos, p. 219-220.

SANDRONI, S.S. (1985). Sampling and testing of residual soils in Brazil. In: Phillipson, H.B. (Eds.), Hong Kong. Scorpion Press, p.31-50.

SCHOBBENHAUS, C.; CAMPOS, D. A.; DERZE, G.R.; ASMUS, H.E. (1984). Geologia do Brasil - texto explicativo, mapa geológico do Brasil e área oceânica adjacente, incluindo depósitos minerais, esc. 1:2.500.000. Brasília, DNPM, $501 \mathrm{p}$.

SHARPE, C.F.S. (1938). Landslides and related phenomena. New York, Columbia University Press, 120p.

SMA-SECRETARIA DO MEIO AMBIENTE (1988). Instabilidade da Serra do Mar no Estado de São Paulo - Situações de Risco.

SUGUIO, K. \& KUTNER, A. S. (1969). Estudo dos sedimentos do rio Cubatão. Bol. Soc. Bras. Geol., 18, (1):57-78

TATIZANA, C.; OGUMURA, A. T.; CERRI, L. E. S.; ROCHA, M.C.M. (1987). Análise de correlação entre chuvas e escorregamentos na Serra do Mar, minicípio de Cubatão. In: CONGRESSO BRASILEIRO DE GEOLOGIA DE ENGENHARIA, São Paulo. ABGE, v.2, p.225-236.

TERZAGHI, K. (1950). Mecanismos de escorregamentos de terra. São Paulo, Grêmio Politécnico, $41 \mathrm{p}$.

VARNES, D.J. (1978). Slope movement types and processes. In: Landslides analysis and control, Washington, National Academy of Sciences, p. 11-33. 
VARGAS, M. (1978). Introdução à Mecânica dos Solos. São Paulo, Editora McGrawHill/Edusp, 509p.

ZARUBA, Q. \& MENCL, V. (1969). Landslides and their control. Amsterdam, Elsevier, Academia, 214p. San Juan, v. 1, p. 87-170.

WOLLE, C.M., GUIDICINI, G., ARAUJO, J.S.; PEDROSA, J. A. B. (1977). Caracterização de um mecanismo de escorregamento nas encostas da Serra do Mar. Separata do Simpósio "Landslides and other Mass Movements", Praga, IAEG.

WOLLE, C.M. (1986). Poluição e escorregamentos; causa e efeito na Serra do Mar, In: CONGRESSO BRASILEIRO DE ENGENHARIA DE SOLOS $\mathrm{E}$ FUNDAÇÕES, Porto Alegre, ABMS, v. 7, p.178-190.

WOLLE, C.M. (1988). Análise dos escorregamentos translacionais numa região da Serra do Mar no contexto de uma classificação de mecanismos de instabilização de encostas. Tese de doutoramento, 300p. São Paulo, Escola. Politécnica, USP. 